Evaluating Education:

Normative Systems and Institutional Practices

Christina Segerholm

Agneta Hult

Joakim Lindgren

Linda Ronnberg Editors

The Governing-

Evaluation-

Knowledge Nexus

Swedish Higher Education as a Case

With Contributions by

Anders Olofsson 


\section{Evaluating Education: Normative Systems and Institutional Practices}

\section{Series editors}

Sharon Rider, Department of Philosophy Science and Technology Studies Center, Uppsala University, Uppsala, Sweden

Michael Peters, University of Waikato, Hamilton, New Zealand 
This series addresses the normative implications of and assumptions behind schemes for assessing and assuring the quality of education at all levels and the role of education in the knowledge society. Educational assessment in most countries has become a standardized function of governments and funders, raising concerns that the distinctive aims of different parts of the educational system and their inherent values base will be eroded over time. Moreover, contemporary education research tends to be compartmentalized, having limited contact with relevant research in philosophy, sociology, history, economics and management studies. This series seeks to rectify this situation by:- examining the historical development, theoretical underpinnings and implicit conceptual assumptions of different regulatory and evaluative regimes and making these explicit - investigating the implicit or explicit values exemplified in and buttressed by policy, and studying its implications in practice - proposing and developing models for alternative practices for realizing goals and promoting norms tied to different conceptions of the purposes of public education and the mission of the university. The series will focus on the pragmatic as well as the theoretical aspects of valuation activities in education and foster dialogue between different approaches within the field, taking as a starting point the fact that processes of valuation are not always quantitative and that these regularly involve a variety of interests and actors. Thus the series will address the diversity of valuation practices, measurements and techniques in education in general at all levels - primary, secondary, tertiary and postgraduate, as well as adult and continuing education -, and higher education in particular, especially regarding potential sources of dispute or controversy. The series will also deal with the consequences of valuation practices in higher education, exploring the ways they resolve, engender or conceal conflicts of values, goals or interests. By bringing forward the normative and institutional dimensions, the series opens the prospect of providing more integrative coverage. This will be of benefit to scholars in the humanities and social sciences, and especially to evaluation researchers and people training to be academic and school administrators. Viewing the field through a philosophical, sociological and historical lens, while incorporating empirical research into the institutions of education and its instruments of assessment, the series seeks to establish and enrich understanding of links between values, pedagogy and evaluation.

More information about this series at http://www.springer.com/series/11809 
Christina Segerholm - Agneta Hult Joakim Lindgren • Linda Rönnberg Editors

\section{The Governing-Evaluation- Knowledge Nexus}

Swedish Higher Education as a Case

With Contributions by

Anders Olofsson

囪 Springer Open 


\section{Editors}

Christina Segerholm

Department of Education

Umeå University

Umeå, Sweden

Joakim Lindgren

Department of Applied Educational Science

Umeå University

Umeå, Sweden

\author{
Agneta Hult \\ Department of Education \\ Umeå University \\ Umeå, Sweden \\ Linda Rönnberg \\ Department of Applied Educational Science \\ Umeå University \\ Umeå, Sweden
}

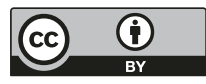

ISSN 2570-0251

ISSN 2570-026X (electronic)

Evaluating Education: Normative Systems and Institutional Practices

ISBN 978-3-030-21142-4

ISBN 978-3-030-21143-1 (eBook)

https://doi.org/10.1007/978-3-030-21143-1

(c) The Editor(s) (if applicable) and The Author(s) 2019. This book is an open access publication.

Open Access This book is licensed under the terms of the Creative Commons Attribution 4.0 International License (http://creativecommons.org/licenses/by/4.0/), which permits use, sharing, adaptation, distribution and reproduction in any medium or format, as long as you give appropriate credit to the original author(s) and the source, provide a link to the Creative Commons license and indicate if changes were made.

The images or other third party material in this book are included in the book's Creative Commons license, unless indicated otherwise in a credit line to the material. If material is not included in the book's Creative Commons license and your intended use is not permitted by statutory regulation or exceeds the permitted use, you will need to obtain permission directly from the copyright holder.

The use of general descriptive names, registered names, trademarks, service marks, etc. in this publication does not imply, even in the absence of a specific statement, that such names are exempt from the relevant protective laws and regulations and therefore free for general use.

The publisher, the authors, and the editors are safe to assume that the advice and information in this book are believed to be true and accurate at the date of publication. Neither the publisher nor the authors or the editors give a warranty, express or implied, with respect to the material contained herein or for any errors or omissions that may have been made. The publisher remains neutral with regard to jurisdictional claims in published maps and institutional affiliations.

This Springer imprint is published by the registered company Springer Nature Switzerland AG.

The registered company address is: Gewerbestrasse 11, 6330 Cham, Switzerland 


\section{Preface}

In this book, we summarise most of what we have learned throughout our research project, Governing by evaluation in higher education in Sweden. When the Swedish Research Council granted us resources for this project in autumn 2012, we had planned to study the national evaluation and quality assurance system that was in operation at the time. One of our major ambitions was to follow a handful of review processes closely from the perspective of the higher education institutions under review and the same processes from the national agency's perspective. As it turned out, this was impossible, and we faced a rather drastic predicament for all social research: the social world changes, and changes may come swiftly. And they did. As we were about to start our project, the national evaluation and quality assurance (EQA) system was terminated. Instead, we faced a period marked by a lack of formal political decisions on a new national EQA system accompanied by intense policy work to develop and design this reformed system.

We turned this to an advantage in that we redirected some of our research efforts to study topics that are seldom researched simply because they cannot be predicted and neatly presented in any research proposal. For example, we were able to empirically study the interesting and important ongoing process of developing policy-in our case, a new national EQA system. We were also able to closely follow the implementation period and the pilot reviews of higher education institutions internal quality assurance systems that were part of that process.

The disruption in our research plan caused by this state of affairs within the Swedish higher education sector also became a crucial issue when we started to plan this book. How should we organise the chapters? In the end, we decided to combine a chronological structure with the overall rationale of our sub-studies; certain parts evolved as results of previous processes through which events unfolded and attracted our curiosity and interest. The book, therefore, is a historical account in which the emphasis is on the most recent national EQA systems in Sweden (2011-2014 EQA) and the present system (2016 EQA) and its development and inception. So, although the book is an anthology, we strived to compile a coherent account that runs throughout the book about contemporary work with EQA policy and practice in Sweden. 
A few words also need to be said about the editorship. Five researchers have been engaged in the research, sharing and contributing to most of the different types of work that have been done: reading, interviewing, analysing, writing, administrating, etc. Our appreciated colleague Professor Anders Olofsson was sadly struck by a stroke in March 2017 and has not been able to contribute to the reanalysis of materials and writing of the texts in the book. However, he was actively involved in the project work, which is acknowledged in footnotes and references. He has also been partly engaged in our editing work, by supplying comments and suggestions for improvements. We want to credit his work with us and the project by recognising that he has done this work with us editors, as stated on the title page.

Umeå, Sweden

Christina Segerholm

Agneta Hult

Joakim Lindgren

Linda Rönnberg 


\section{Acknowledgements}

We are grateful for the support given by the Swedish Research Council (grant 7212012-5424), Umeå School of Education at Umeå University (grant dnr 223-263612), the Faculty of Social Science at Umeå University and the Faculty of Humanities at Mid Sweden University.

In finalising the book, Professor Jenny Ozga's comments were especially appreciated. In particular, we want to thank her for introducing the expression and the same time conceptual understanding laid down in "evaluation as a practice that makes knowledge work for governing".

Our thanks also go to good colleagues from who we have received valuable comments, questions and suggestions that inspired us further. Others who have helped us in our writings that we would like to thank are the anonymous reviewers of our book proposal and final manuscript, along with the group of $\mathrm{PhD}$ students who engaged in a discussion about parts of the book. Last but not least, to all persons who set aside time to be interviewed by us, thank you! 


\section{Contents}

Governing by Evaluation: Setting the Scene

Christina Segerholm, Linda Rönnberg, Joakim Lindgren, and Agneta Hult

National Evaluation Systems

Christina Segerholm and Joakim Lindgren

Europe in Sweden . .

Christina Segerholm and Agneta Hult

Navigating Higher Education Institutions in Times

of Quality Assurance: The Assumptive Worlds of Vice Chancellors .... .

Agneta Hult

Hayek and the Red Tape: The Politics of Evaluation

and Quality Assurance Reform - From Shortcut

Governing to Policy Rerouting.

Joakim Lindgren and Linda Rönnberg

Quality Evaluations and the Media.

Linda Rönnberg

Enacting a National Reform Interval in Times of Uncertainty:

Evaluation Gluttony Among the Willing.

Joakim Lindgren, Linda Rönnberg, Agneta Hult, and Christina Segerholm

Relaunching National Evaluation and Quality Assurance:

Expectations and Preparations

Christina Segerholm 
Relaunching National Evaluation and Quality Assurance:

Governing by Piloting . . . . . . . . . . . . . . . . . . . . . . . . . . 157

Joakim Lindgren, Linda Rönnberg, Agneta Hult, and Christina Segerholm

Evaluation Machinery, Qualocrats, and the Seemingly

Inevitable Problem of Expansion.

Joakim Lindgren, Linda Rönnberg, Agneta Hult, and Christina Segerholm

Appendix

Christina Segerholm 


\section{Editors and Contributors}

Christina Segerholm is professor of education at the Department of Education, Umeå University. Her main research interests are education policy, evaluation influence and education governance. She teaches undergraduate, mostly in teacher education, and graduate courses. ${ }^{1}$

Agneta Hult is an associate professor in education at Umeå University. Research interests are mainly evaluation influence in school and higher education, juridification effects in school and assessment in higher education. Her teaching interest is foremost directed to teacher education.

Joakim Lindgren is an associate professor in education at the Department of Applied Educational Science, Umeå University. His scholarly interests are education policy, evaluation, school inspection and problems of socialisation and juridification in education.

Linda Rönnberg is an associate professor in political science and senior lecturer at the Department of Applied Educational Science, Umeå University. She is also a senior research fellow at the University of Turku. She researches education governance, politics and policy with a focus on evaluation and inspection, marketisation/ privatisation and internationalisation.

\footnotetext{
${ }^{1}$ Corresponding author christina.segerholm@umu.se
} 


\section{Abbreviations}

ASHEI the Association of Swedish Higher Education Institutions (SUHF Sveriges universitets- och högskoleförbund)

ECA the European Consortium for Accreditation in higher education

EEA the European Economic Area

EFTA the European Free Trade Association

EHEA the European Higher Education Area

EI Education International

ENQA the European Association for Quality Assurance in Higher Education

EQAF the European Quality Assurance Forum

EQA Evaluation and Quality Assurance

ESG Standards and Guidelines for Quality Assurance in the European higher education

ESU the European Students' Union

EUA the European University Association

HE higher education

HEI higher education institutions, i.e. universities and university colleges

IAU the International Association of Universities

INQAAHE the International Network for Quality Assurance Agencies in Higher Education

NOQA the Nordic Quality Assurance Network

OECD the Organisation for Co-operation and Development

QA quality assurance

SNUS the Swedish National Union of Students (SFS Sveriges förenade student-kårer)

SHEA the Swedish Higher Education Authority (UKÄ Universitetskanslers-ämbetet)

SNAHE the Swedish National Agency for Higher Education

CBPS the Centre for Business and Policy Studies (SNS Studieförbundet närings-liv och samhälle)

SAUTR the Swedish Association of University Teachers and Researchers (SULF Sveriges universitetslärarförbund)

TCO the Swedish Confederation of Professional Employees (Tjänstemännens centralorganisation) 


\section{List of Figures}

\section{Europe in Sweden}

Fig. 1 From left to right: European/international to Swedish dissemination channels; internal Swedish dissemination channels

\section{Relaunching National Evaluation and Quality Assurance:}

\section{Expectations and Preparations}

Fig. 1 Overview of components, aspect areas, and perspectives in the 2016 EQA system. (SHEA 2016b, p. 18)

Fig. 2 Overview of what aspect areas and perspectives that are emphasised in the different evaluation types (components). (SHEA 2016b, p. 21)

Fig. 3 Illustration of try-out guidelines translated into English by the SHEA. (SHEA 2016d, p. 25) 


\section{List of Tables}

\section{Quality Evaluations and the Media}

Table 1 Public administration and news media interactions: strategies and stances................................................................ 106

Table 2 SNAHE and SHEA evaluation results press releases,

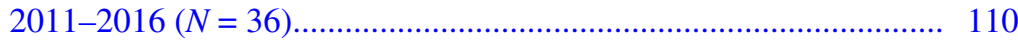

Table 3 Subject area: Education .............................................................. 112

Table 4 Subject area: Specialist nursing ..................................................... 114

Enacting a National Reform Interval in Times of Uncertainty: Evaluation Gluttony Among the Willing

Table 1 Summary of cases in terms of size, age, profile, and education quality. 


\title{
Governing by Evaluation: Setting the Scene
}

\author{
Christina Segerholm, Linda Rönnberg, Joakim Lindgren, and Agneta Hult
}

\begin{abstract}
This introductory chapter starts by outlining the aim of the book: to analyse and discuss the interplay between governing, evaluation and knowledge with an empirical focus on Swedish higher education. It then goes on to locate this aim and the intended contribution within the wider research context and in previous studies. The chapter also highlights some important national traits of the Swedish case and Swedish higher education policy development, before presenting the overall conceptual frame employed in the book and the project it builds on. Finally, an outline of the forthcoming chapters is provided.
\end{abstract}

\section{Introduction}

In this book, we address and problematise issues of how, where and why evaluation and quality assurance reforms are shaped, legitimised and enacted in the context of higher education. More specifically, the aim is to analyse and discuss the interplay between governing, evaluation and knowledge, with an empirical focus on Swedish higher education. We are interested in the pivotal role of knowledge as a governing resource, and we seek to highlight the particular features of evaluation as a practice that makes knowledge work for governing.

We draw on extensive empirical studies and findings from the project Governing by evaluation in Swedish higher education 2013-2018, in which we sought to understand the governing-evaluation-knowledge problem, by focusing on international and national contextual and political frames underlying recent evaluation and quality assurance reforms in higher education. We also sought to understand the

\footnotetext{
C. Segerholm $(\varangle) \cdot$ A. Hult

Department of Education, Umeå University, Umeå, Sweden

e-mail: christina.segerholm@umu.se; agneta.hult@umu.se

L. Rönnberg · J. Lindgren

Department of Applied Educational Science, Umeå University, Umeå, Sweden

e-mail: linda.ronnberg@umu.se; joakim.lindgren@umu.se
}

C. Segerholm et al. (eds.), The Governing-Evaluation-Knowledge Nexus,

Evaluating Education: Normative Systems and Institutional Practices,

https://doi.org/10.1007/978-3-030-21143-1_1 
enactments of these reforms in Swedish higher education institutions and in the responsible national evaluation agencies. While working with our project, we found that the term nexus captured much of our research ambition and understandings of these relationships. Hence, the use of nexus in the title of the book refers to both the meaning "connection, link" (Merriam-Webster Dictionary n.d.), and to the older, Latin meaning "the act of binding together" (Wiktionary n.d.), or "a binding together" (Oxford Dictionaries n.d.). Throughout this book, we use the development of evaluation and quality assurance (EQA) systems in Swedish higher education to explore and analyse how governing, evaluation and knowledge are connected and bound together, in the activities of policy travel and brokering, decision-making, media coverage, design, enactment, translation and by assumptions and conceptions of quality.

We recognise the intimate connection between geographical space and time and the need to acknowledge how the patchwork of higher education governance varies across (and within) nations. Paraphrasing Massey (2013), we could imagine ourselves taking a train across the international higher education landscape. Despite transnational influences and modes of governing, we would be "cutting across a myriad of stories going on". Massey's allegory identifies the higher education landscape as "a pincushion of a million stories", and Sweden offers a particular national framework for particular stories. Sweden was the first European country to create a unified mass higher education system in the 1960s and 1970s (Neave 1998). Based on modernist ideas of reform through social engineering (Larsson et al. 2012a), forms of evaluation that aimed at improving the system were developed and set up as a direct response to this development. From the outset, governing work depended on knowledge and expertise and used evaluation as a specific kind of knowledgebased form of enactment of governing. We might even say that epistemic governance and Sweden is an old affaire de Coeur. So, whereas the general utopian ideas of using evaluation for purposes of improvement have remained intact, the welfare state in Sweden has undergone dramatic changes, as has the higher education system and the modes of governing the system by evaluation. Such forms of historical continuities have inspired Swedish scholars to challenge the orthodoxies of the governance narrative and develop more context-sensitive descriptions in terms of, for example, a shift from social engineering to "advanced liberal engineering" with emphasis on the important role of regulatory apparatuses involving "standardisation, monitoring, auditing and evaluation" (Thörn and Larsson 2012, p. 263). At the same time, Sweden shares a dominant rationale for contemporary governing based on modernity with most countries in Europe and beyond. That is, the rationale governing by objectives/goals and results/outcomes, which in turn requires feedback mechanisms like evaluation (Therborn 1995).

The particular contemporary Swedish history, the specific continuities, displacements and breaks, makes it highly informative to zoom in on the Swedish case in order to explore the role of evaluation in governing higher education. As such, the book is a contribution to understanding governing that actively works with transnational developments and interrogates them through detailed and specific national, local and institutional exploration. Illustrations from a specific national case may 
also help other researchers to identify specificities and thus to contribute to scholarship that acknowledges globalising and transnational developments but pays attention to translation in a particular context.

\section{Research Context and Project Contributions}

In Europe and beyond, higher education has increasingly been targeted by political initiatives aimed at intensifying the societal and economic benefit from this sector (Shattock 2014), and researchers have been attracted to studying these developments more closely. Common observations from a vast number of studies point to the expansion or massification in terms of the number of students; the changed relations between the State and higher education; the importance of internationalisation/globalisation; transnational governance; mergers of higher education institutions; a move towards market-oriented policies - including commodification and increased media relations; the adoption of new public management in higher education institutions' (HEIs') internal governance structures; the relation between academic freedom and institutional autonomy; and the shift to performance-based funding (e.g. Olssen and Peters 2005; Gornitzka et al. 2007a; Herbst 2009; Schuetze et al. 2012; Sultana 2012; Rider et al. 2013; Goodman et al. 2013; Shattock 2014; Cai et al. 2016; Fumasoli et al. 2017). In the European context, the significance of a common degree structure and of outcome-based learning objectives and standards (e.g. Brøgger 2018; Normand 2016) are also recurrently observed. There is indeed a rich literature covering different aspects of EQA in higher education in the wake of the developments described above. Such studies include, for instance, systemic and structural aspects of these relationships, issues pertaining to design selection and implementation of quality assurance activities and tools, as well as critical analysis of quality assurance as regulation and occupation (c.f. Travers 2007; Westerheijden et al. 2007; Pratasavitskaya and Stensaker 2010; Paradeise and Thoenig 2013; Rosa and Amaral 2014; Enders and Westerheijden 2014; Jarvis 2014; Leiber et al. 2015; Beerkens 2015; Brady and Bates 2016; Toots and Kalev 2016, to give a few examples from the last decade). However, such studies have rarely dealt with the Swedish case. In fact, with a few exceptions, research in Swedish higher education (c.f Geshwind and Forsberg 2015; Wedlin 2011; Wedlin et al. 2017) have seldom explicitly targeted EQA practices (c.f. Gröjer 2004; Karlsson et al. 2014; Lindgren 2012; Kettis and Lindberg-Sand 2013). By this book, we seek to add to this literature, by focussing on different facets and the interplay of and between knowledge, evaluation and governing in higher education.

As a point of departure, we suggest that contemporary transformations in higher education governance reflect moves of simultaneous deregulation, decentralisation and self-governing on the one hand and reregulation and centralisation on the other. Inherent in these activities is the dilemma of balancing (external) control/accountability and support (House 1993; Karlsson Vestman 2011) in education governance and evaluation, as also noted in research on global and European education policy 
(Ozga and Lingard 2006). In the words of Campano, "These complex, often contradictory governance shifts in higher education represent a process that could be of considerable interest, were it included in the broader debate on 'governance' that has emerged over the last 15 years in the social sciences" (2011, p. 1622). Not only do these transformations of higher education concern governance shifts and tensions, but they also incorporate different actors and work processes as well as the emergence of the so-called intermediary bodies (Neave 1998). Furthermore, the transformations encompass ideas of what higher education (or a university) is and should be (Karlsohn 2016). Here one of the key ideas in the book emerges, namely, that governance may transform social realities in profound ways.

Different means are used in these political endeavours and balancing acts, and in this volume, we have deliberately concentrated on exploring EQA systems as part of these governing efforts. We find that much of the transformations noted in contemporary research on higher education are in fact visible in (national/state/regional) EQA systems. Such systems are themselves subjects for reforms, policies and political decision-making, in how they best are designed, implemented and practised (e.g. Salter and Tapper 2000; Dan $\varnothing$ and Stensaker 2007). They may therefore capture governing ambitions, moves and tensions, as well as the extensive policy work and enactments by different actors involved in these processes in diverse institutional settings.

Governing by evaluation in higher education always presupposes and involves different forms of knowledge. Firstly, evaluations themselves are based on particular epistemologies and choices regarding methodological designs, and their concrete enactment involves practical forms of know-how. Moreover, such evaluations also necessitate some knowledge about the real world of higher education systems, including the formal laws and soft rules that HEIs - and evaluations for that matter must adhere to.

Fuelled by efforts manifested in the Bologna Process and the formation of the European Higher Education Area, organisations such as the European Association for Quality Assurance in Higher Education (ENQA) and their Standards and Guidelines for Quality Assurance (ESG) (2015) are increasingly influential in governing higher education across nations and systems (Enders and Westerheijden 2014). These policy developments also carry potential (re)locations of power and relationships, in which national systems and higher education institutions are navigating their roles and functions (Lingard and Rawolle 2011).

We argue that Sweden is a particularly productive site for examining the complexities of governing higher education in the context of EQA. Several national reforms have been implemented over the last three decades (see the section on the Swedish case), producing certain governing tensions, reflecting moves of the simultaneous deregulation and decentralisation of self-governing on the one hand and reregulation on the other, manifested in:

(i) Problems of balancing control/accountability and development/enhancement (learning). 
(ii) Challenging international-national-local institutional relationships, for instance, in the exclusion of the Swedish national agency as a member of the strong policy organisation the ENQA.

(iii) An almost 2-year-long period in which no reform decision of a new national EQA system was taken, but tensions were intended to be restrained.

These particular circumstances formed a unique opportunity to study the contemporary relations between governing, evaluation and knowledge in higher education and its local institutional, national and international (European) policies and practices. In taking this approach, our research reported in this book:

(a) Provides insights into the power of European policy flows and activities concerning EQA in higher education and their national and institutional enactments. We see that the interrelatedness of European and national policy activities, paired with a specific national reform situation produced a powerful governing context, in which higher education institutions have to act on and reconcile various internal and external demands and conceptions of quality in higher education.

(b) Contributes understandings of governing by evaluation at a point in time when one national EQA system was terminated, but the content and design of the new system that was to replace it was pending for almost 2 years. Previously, the systems followed one another without interludes, and this temporary halt was a new situation for the higher education sector. By studying national politics and policy processes in this "interval" between two major quality assurance reforms and by analysing how higher education institutions responded to and handled national and international policy signals, we show how governing is "done" when a national reform is expected but not yet decided.

(c) Generates findings from a particular research design (see the Appendix) in which the evaluators and the evaluated were studied in parallel, facilitating a holistic view of external evaluation processes. This design gave us knowledge of how certain governing signals in the evaluation processes are enacted in the work of higher education institutions. As will be shown, this enactment varies and is infused by local institutional contexts, knowledges and experiences.

(d) Provides knowledge from the rare opportunity to study national EQA reform "in the making" and its short-term influence on education policy and practice in real time. The design allowed us to study how the policy for a new national EQA system is made and put into practice in the Swedish higher education system as the events unfolded. This gave us knowledge of, for instance, the stress put on European policy, the importance of actors' conceptions of quality in higher education, of what types of knowledge are required to translate policy into practice, to examine, measure and assess quality, and hence make knowledge work for governing in evaluation processes.

Furthermore, the book offers opportunities for comparisons to Sweden for nations that may share some of the particular characteristics of the Swedish case, in order to gain collective insights, understandings and knowledge about the 
contemporary governing of higher education and how evaluation, quality assurance and knowledge are inextricable parts of this. The book contributes to descriptions and analysis of how evaluation expands over time and reaches out and involves an increasing number of actors and activities at different levels, nationally and internationally, in the governing of higher education. Therefore, the book also responds to the ambition expressed by Furubo and Stame (2019): to provide "a critical view" of evaluation, scrutinising it within a wider societal context, something not done that often. As called for by scholars from different research perspectives, the book offers an illumination of the relationship between the construction of policy and practice in higher education (Wedlin 2011, pp. 46-47) or what Gornitzka et al. (2007b, p. 13) identified as "[a] need to find ways of looking at the relationship between policies and practices in higher education". From our rich empirical material, we also describe in some detail "the missing link", that is, what happens with political signals and decisions in the everyday practice of higher education. We draw on our empirical work to illustrate and problematise different aspects and facets of the relations between governing, evaluation and knowledge in the context of Swedish higher education.

In the remainder of this chapter, we describe the case of Sweden and some general features of higher education governance. We also note the significance of the Bologna Process and the subsequent policy and governing work in the reshaping of the higher education system during the last decades. We then discuss the conceptual triad that is located at the core of our research interest, namely, governing, knowledge and evaluation. The chapter ends by introducing the forthcoming chapters.

\section{The Swedish Case}

Although rather large in geographical terms, Sweden, with its approximately 10.2 million inhabitants, is not a big country in population. During a major part of the 1900 s, it was a rather homogenous country in that it had a protestant state church, Swedish as administrative and major language, and was ruled for more than four decades by the Social Democratic party (1932-1976). Politically, Sweden is known for the Social Democratic party's control of the economy by central planning, along with corporatist arrangements (c.f. Rothstein 1992). The famous so-called Saltsjöbaden spirit (Larsson et al. 2012b, p. 16-17) came out of an agreement in 1938 between the workers' union and the employers' organisation. The agreement stipulated that the labour market should not be subject to regulations by the government. Instead, labour market issues should be handled by the different labour market actors in consensus-seeking processes without interference of the government. Another signifying trait of the Swedish post-war state was of course its social welfare expansion and growth. Swedish welfare came to be characterised by general distribution of social welfare and high public spending in areas such as social services and insurance, health care and education. This resulted in a particular form of social democratic welfare state (Esping-Andersen 1990) in which comprehensive 
and publicly financed welfare were conceived as the norm. Taken together, institutional arrangements like these are argued to have built trust in the state and also gave some stability for the welfare society project, aided by a culture of consensusseeking procedures and extensive consultations prior to reforms (Larsson et al. 2012b, p. 16-17).

From the 1930s and onwards, the development of the welfare state through centrally planned piecemeal social engineering took off (Larsson et al. 2012b, p. 16-17). Trust and social engineering are important characteristics for Sweden, and political decision-making and extensive reforms were to be based on expert knowledge (Larsson et al. 2012b, p. 12-14). Such expert knowledge was achieved through the recruitment of experts to national committees representing different interests in society. Reports from the committees were sent out to various stakeholders for consultation before political decisions were taken. This government rationale was in place more or less up until the 1980s, when the economic crisis of the 1970s put an end to the expanding welfare state with its social and educational reforms.

In general, Swedish politics, with its proportional electoral system and multiparty system, has often been seen as a culture of relative political consensus, along with willingness to cooperate and negotiate. A history of minority governments and the need for bargaining and coalitions have counteracted more confrontational "the winner takes it all" political approaches, as promoted, for instance, by the English political system (c.f. Lewin 2002). However, the last decades witnessed an increasing political polarisation in the form of two dominant blocs (a predominantly social democratic and centre-right, respectively). The most recent elections have complicated this picture, as a growing populist right-wing and anti-immigrant party is holding the balance of power between the blocs (Aylott and Bolin 2015). The 2019 minority government coalition (Social Democratic and Green Party) came into office after seeking support from some of the parties in the former centre-right bloc.

Looking closer at education policy, a signifying trait of the post-war era has been the political advocacy of equivalence (sometimes translated to equity) as a means to promote equality, increasing social justice and mobility and to counteract the effects of an uneven distribution of resources. However, economic and societal transformations of the Swedish welfare state have contributed to gradually transform education to be conceived as a "private good" rather than a "public good" (Englund 1993). A focus on individual freedom of choice, individualised responsibility, competition and individual capacity building now serve as general guiding principles for education policy (Englund 1993; Dahlstedt and Fejes 2019). The social justice dimension once incorporated in the notion of equivalence has been challenged and arguably infused with new meanings. It should however be noted that higher education in Sweden is free of charge to Swedish and European students, and there is still a strong policy emphasis on widening access and participation in higher education, along with strivings to actively recruit underrepresented student groups (c.f. Government Offices of Sweden 2017).

To sum up, the strong social democratic heritage and power as a form of "hegemonic force" (Agius 2007, p. 585) has framed the history of the Swedish welfare state. Although influenced by several characteristics of New Public Management 
(Pollitt 1995), neoliberalism has not become what Braithwaite (2005, p. 3) calls "an institutional reality" in Sweden, as neoliberalism has not been institutionally effectuated in terms of "a diminished public sphere". The influx of market ideas has increased the role of regulation in shaping policy and politics, which is highly evident within the education area. Market ideas and consumerism have increased the need for bureaucratic regulation, audit, inspection and other forms of control. We find it therefore apt to lean to ideas of "regulatory capitalism" as a broad description of the contemporary regulatory design and institution - "one that is being constituted, shaped, constrained and expanded as a historically woven patchwork of regulatory institutions, strategies and functions" (Levi-Faur 2017, p. 289; see also Braithwaite 2005). In the next section, we move from general historical and social depictions to the particular characteristics of Swedish higher education.

\section{Swedish Higher Education and Its Policy Context}

The majority of the 48 Swedish HEIs are public. There are also a small number of independent higher education providers that predominantly give courses within a specific and more limited subject area. Today, about 350,000 students attend these HEIs. The number of students enrolled in Swedish higher education has increased considerably over time. Going back to the 1977 higher education reform, when most postsecondary education was organisationally relocated to higher education, the number of students increased to reach about 160,000 in the early 1980s. An even more intensified student expansion was evident in the 1990s and the 2000s, to reach a high point with 365,000 students in 2010 (the Swedish Higher Education Authority, SHEA 2018). Higher education staff are employed by the state, making higher education the largest public sector in terms of the number of persons employed. In 2017 there were more than 75,000 HEI employees (the corresponding figure for full-time equivalents is about 60,000). Research and teaching staff make up about 60 per cent of all employed in Swedish higher education. The expansion of higher education is discernible in the number of research and teaching staff as well, which has increased over time. This also goes for the number of hired administrative personnel in HEIs. This category of employees has increased by almost one third in the last decade (SHEA 2018).

Within a government context, it is important to recognise that Sweden has a political system in which the ministries within the government are small compared to many other countries. The national agencies are part of the state in that they (ideally) implement and administrate parliamentary and government decisions, and they are separated from the government office and the ministry offices. Swedish agencies are often portrayed as largely autonomous compared to many other countries. The autonomy, independence and accountability of agencies are regulated by laws adopted by the parliament and by ordinances and provisions issued by the government. Each agency is also governed by annual appropriation directions, which regulate the activities, objectives and economical resources for the agency. 
This arrangement means that a ministry and its political ministers are not allowed to intervene in individual matters handled by the agency (known as ministerial rule). Administrative discretion, coupled with extensive informal contacts with the ministry, along with agency employees' expertise, place the agencies in an influential position (Rothstein 2005; Pierre 2004).

In the case of higher education, there are two major national agencies: the Swedish Higher Education Authority (SHEA, Universitetskanslersämbetet, UKÄ) and the Swedish Council for Higher Education (Universitets- och högskolerådet, $U H R)$. The former is responsible for national supervision, EQA and some other government assignments, and in this book this intermediary body will play a central role. The latter agency works with admissions to higher education, evaluates foreign students' qualifications and brokers international exchange, and thus its scope is not within the primary interest of this book.

The Higher Education Act (SFS 1992:1434 n.d.) and the Higher Education Ordinance (SFS 1993:100 n.d.) apply for all public HEIs, with some special regulations for the Swedish University of Agricultural Sciences and the Swedish Defence University. They also receive annual appropriation directions from the government concerning the use of the annual budget and how to report back to the government. For some HEIs, this means that they are commissioned to undertake special assignments, for example, decentralised medical education or education in minority languages.

The Swedish higher education system mainly consists of two kinds of HEIs: universities and university colleges. Universities have a more far-reaching right to award degrees compared to university colleges. University colleges have to apply to the national agency for the right to award degrees and certificates for degrees in art, professional degrees, and master's and doctorate degrees, while universities have to apply for the first two types of degrees and are free to award master's and $\mathrm{PhD}$ degrees. Independent providers receive degree-awarding powers from the government. However, as we show in the chapter "National Evaluation Systems", these are conditional rights that may be revoked, should the HEIs not live up to the requirements set in national EQA exercises. Universities are often larger than university colleges, meaning that they comprise of several faculties and scientific areas. Some HEIs are specialised in, for instance, technology, medicine or art.

Higher education is free of charge for citizens within the European Union, the European Economic Area and Switzerland. Before 2011, higher education was free of charge for all. Higher education in Sweden is funded by tax revenues. Some other arrangements also exist but are scarce. From the 1993 reform (Government Bill 1992/93:1), performance funding was introduced, meaning that a per capita revenue is allocated for each student registered on a course, and a per capita revenue is allocated for each student who fulfils the course requirements. This reform also introduced mandatory internal quality assurance at the HEIs and could probably be described as the first move after the Second World War towards market orientation, since it introduced incentives for the HEIs to compete in order to attract students. This reform was also a move towards increased institutional autonomy, in that the HEIs could now decide on curricula (with the exception of professional programmes) 
that earlier were centrally decided. In the comprehensive study by Bauer et al., they summarised the shifts as follows:

The shift in authority was primarily characterized by the move away from centrally regulated and steered institutions to more autonomous institutions, led by more powerful institutional leaders who were now to compete in an education marketplace. Such a shift in the distribution of authority between the state and the institutions naturally brought about a change in the authority in the central bureaucracy, with a new emphasis on accountability rather than on planning and managing the system. (Bauer et al. 1999, p. 101)

The entire degree structure of the Swedish system changed in 2007, when the "three-cycle" system (degrees at three levels) from the Bologna agreement was decided and Sweden abandoned the previous structure with two levels (Government Bill 2004/05:162; Parliament Standing Committee on Education 2005/06:UbU3). The influence of European policy became apparent with this reform and clearly spelled out in the government's motivation of the proposed change:

In order to contribute to Swedish higher education's international comparability, attraction and currency, the Government proposes and make assessments concerning changes in the educational and degree structure in Swedish higher education. This is done particularly on the basis of Sweden's participation in the so-called Bologna process, which today includes over 40 European countries. This process aims to promote mobility, employability and the competitive power of Europe as a continent of education. (Parliament Standing Committee on Education 2005/06:UbU3 n.d., p. 1)

This parliamentary decision led to a revision of all national requirements for degrees at all three levels. It also led to a major revision of local plans for different education programmes and subject courses at the HEIs. Programmes and courses should, from then on, be based on the rationale of the relation between expected learning outcomes (learning objectives) and acquired learning outcomes and whether or not the latter was in line with the requirements for a specific degree.

These developments have continued with a reform to further strengthen HEI autonomy (Government Bill 2009/10:149), leaving the HEIs to decide on internal organisational structure, on types of positions and requirements for employment, and to allocate resources internally at their own discretion. From the 1993 reform onwards, a number of national EQA systems have been decided, implemented and operated, which we will analyse in more detail in the chapter "National Evaluation Systems". Next, we will elaborate on our general understanding of the three concepts that we see as central to explore the nexus.

\section{Understanding Governing, Knowledge and Evaluation}

As an overall point of departure, we have used governing, knowledge and evaluation as a conceptual frame. The different chapters also draw on additional theoretical resources, some more and others less, in order to bring out relevant perspectives from the presented data. We have adopted an eclectic approach to further our understanding of these processes, and recognising this deliberate theoretical plurality has been an important basis for our joint work in the research project. 


\section{Governing}

Our interest in researching governing goes back to our previous projects on quality assurance, school inspection and education governing in compulsory education (c.f. Ozga et al. 2011; Grek and Lindgren 2015; Carlbaum et al. 2014). Here, governing is conceptualised as a verb, as a way to emphasise the actual work and doings of, and in the policies that governing entails. This formed our overall conceptual approach to governing, and we draw on this to research governing of higher education and the work that are done in these processes. Our approach to governing draws attention to the work of actors and their mediation. They engage in activities that build on and foster certain knowledge that move across nations and contexts in particular ways, which relies on data and comparison as sources of legitimacy.

We understand governing as the activities composed of assemblages of places, people, policies, practices and power (Clarke 2015, p. 21). This notion of governing was put forward as a way of trying to "focus on the complexity, contestation and translation of governing practices that avoided the system-theory references of governance and the totalising tendencies of governmentality" (Clarke 2015, p. 12-13). This conceptualisation, however, does not entail a view of the complete hollowing out of the state (c.f. Rhodes 2007) but rather points to the practices and doings in diverse, complex and multilevel arrangements and acknowledges that (state) governing in itself is a way to make this diversity of arrangements governable (c.f. Pierre and Peters 2000). However, the state is not a monolithic entity but encompasses a multitude of actors, opinions and actions, as well as the tensions within and between them. In this context, neo-institutional approaches and insights from organisational studies are useful in order to further analyse such governing complexities (c.f. Jacobsson et al. 2015).

Furthermore, ideas on decentred governance draw attention to the importance of actors' contingent desires, beliefs, preferences and intentions as part of meaningful actions and activities of governing, that is, that governing works through processes where actors "create and act on meanings" (Bevir 2011, 2013, p. 56). This means that we pay careful attention to individuals by examining "the ways in which patterns of rule, including institutions and policies, are created, sustained, and modified by individuals whose actions (...) arise from the beliefs individuals adopt against the background of traditions and in response to dilemmas" (Bevir, 2013 p. 65).

We see the acts of governing as a set of multiple processes, involving different forms of work, for instance, through mobilisation of agents and agencies in order to realise certain aims. National EQA systems may be used and adapted to suit very different circumstances and expectations. EQA systems respond to and are affected by changing political demands and display both gradual and more drastic processes of change. The stress on governing as work and doings has led us to recognise the importance of policy enactment (rather than implementation) (Ball et al. 2012). Enactment is used to draw attention to that policy, as encoded text must be decoded in concrete environments, often in messy and non-linear processes of interpretation and translation. As Ball and his colleagues argue: "Enactments are always more 
than just implementation, they bring together contextual, historic and psychosocial dynamics into a relation with texts and imperatives to produce action and activities that are policy" (Ball et al. 2012, p. 71). With our approach, we want to highlight that the work of "doing EQA" entails enactments that are embedded in different institutional and organisational contexts and that local contexts matter. We are also interested in the political work that is being done, the speed and pace at which these governing activities are designed and enacted (c.f. Jessop 2015), as well as in the actors that broker and/or carry knowledge and "do" policy. In this book, we will introduce the reader to a particular group of people we have named "qualocrats" who carry and embody such important knowledge and expertise in the field of EQA in higher education.

We claim that "doing" governing is dependent on sharing and negotiating knowledge, to produce (certain) knowledge and to define what counts as valid knowledge, as well as creating solid bases for decisions in the evaluation of central issues. Of particular interest to us is "meditative" governing (Jacobsson 2010), which points to the importance of compared experiences and shared ideas in doing governing. The concept is related to the idea of policy learning and teaching, translation, brokering and networking, as in the "actual work" (Sassen 2007, p. 37) of governing. As Ozga (2016, p. 71) states, we can also discern the emergence of

new kinds of governing work from particular groups of actors who are positioned at key points of intersection of knowledge production and practical problem-solving. This work demands skills in translating information into 'practical knowledge', mediating conflict and brokering interests. (Ozga 2016, p. 71).

In our project and in the forthcoming chapters, the EQA governing work of such actors and the knowledge brokered in these translations and interactions are explored further.

\section{Knowledge}

As a knowledge problematic, governing by evaluation in higher education can essentially be understood as a state practice involving two steps. First of all, the state needs knowledge about the higher education sector. Borrowing an analogy from Scott $(1998$, p. 2), we might say that the Swedish state, as it struggled to get a handle on the expanding higher education system in the 1960s, was "partially blind; it knew precious little" about the inner workings of higher education institutions, whose creation and transmission of knowledge were underpinned by a principle of university autonomy, which allowed them to organise their work without being particularly restricted by, or accountable to, outside bodies. Back then, programmes were designed, delivered and assessed, and standards were defined and set, within small, local, homogeneous and well-socialised academic communities. These appeared, in the eyes of the state, as obscure as a wild forest with its rich flora of 
minerals, insects, animals, grasses, flowers, mosses, shrubs and trees, with their mycelial networks, mycorrhizal fungi and pheromones.

In the next step, as carefully documented by Scott (1998), the state's solution to the problems of representing complex and illegible local practices is often to remake them. The Swedish state used rationalist and centralist measures like central planning, resource allocation and detailed national regulations concerning study plans (Gröjer 2004; Askling 2012). As noted earlier in this introduction, new modes of governance have replaced these efforts. We might think of the contemporary remodelled higher education landscape, based on the credit-based modular formats, as an equivalent to the mono-cropped scientific forest that appears easy to survey, measure and evaluate.

Regardless of the forms of state governing, evaluation has been a prime tool used in order to retrieve knowledge. But evaluation not only has transformative effects on social realities. Social realities can also be transformed in order to be legible to evaluation - in order to be seen by the state (Scott 1998). Once again, we touch on the important issue of transformation and, more specifically, on questions about forms of practices, values, knowledge and potential that might be lost in such transformations.

As noted above, governing by evaluation - the work of formulating and enacting - also involves different forms or phases of knowledge. In order to explore the role of knowledge, we draw on the work of Freeman and Sturdy (2015), who conceptualise knowledge as embodied, for example, through tactic and verbal experience, inscribed, in different forms of texts and artefacts, and enacted, via what is actually done or carried out. Using this three-phase conceptualisation, we identify and describe forms and movements of knowledge that are manifested, incorporated and transformed in governing by evaluation as a social practice encompassing several arenas and groups of actors.

Starting with embodied knowledge, it refers to "the knowledge held by human actors and employed and expressed by them as they go about their activities in the world" (Freeman and Sturdy 2015, p. 8). In this book, we will show that the expertise of key actors, such as the above-mentioned qualocrats, is absolutely vital. Such knowledge includes specific knowledge of higher education governance, institutional and organisational design and experiences from EQA. In times characterised by rapid change and speed, the plasticity and flexibility of such knowledge become particularly important.

The upcoming chapters will also show how documents in the form of policies, guidelines, reports, self-evaluations and so on are equally imperative to evaluative activities. Such inscribed knowledge serves to model, inform, standardise and coordinate actors' work and entail "particular ways of seeing, thinking and knowing; such artefacts can consequently serve to constrain and discipline our interactions with the world and with one another" (Freeman and Sturdy 2015, p. 11). Inscribed knowledge can be stored and travels in time and space. Importantly, inscription is often, at least temporarily, an end product that obfuscates the material process that gave rise to inscription (Latour and Woolgar 1979). We have sought to acknowledge, 
or "unbox", these material processes and the work of interpretation and translation that are ineluctable aspects of working with inscribed knowledge. One example is the production of text for different audiences. As we will show, writing and editing text in the context of national EQA often require collective efforts. This leads us to the third phase of knowledge, enacted knowledge, which is the form embodied and inscribed knowledge takes when expressed in doings and actions, for instance, the ways in which new knowledge is generated as people meet, use and share embodied and inscribed knowledge. Although embodied and inscribed knowledge inform and frame actions, enacted knowledge is never totally determined. Thus, we find that this concept is particularly productive when studying the concrete knowledge use and production of policy actors in evaluative and governing activities that cherish certain bureaucratic ideals, for instance, in terms of formal justice and comparative consistency (Molander 2016). As noted by Freeman and Sturdy (2015, p. 15), enacted knowledge is "characterized by a high level of interpretative flexibility which means that one instance of enactment may differ very significantly from another, even when both instances draw on the same embodied and inscribed knowledge". In this book, we use this conceptual scheme as a way to explore what forms of knowledge are in operation in the work of governing by evaluation. In our research project, we have focussed on how different forms of knowledge move, take shape and are reshaped in the course of evaluation reform and activity, as actors go about in their work to make things happen (or not) in the context of these processes.

In order to "make things happen", evaluation reform has also drawn on knowledge of human conduct developed in the social sciences during the twentieth century. Contemporary ideas of total quality management, which are permeating mandatory internal quality assurance systems in higher education, were developed from scientific management via the human relations movement, with increasing emphasis on humanisation through self-government, empowerment, involvement and consensus (Boje and Winsor 1993; Barrow 1999; Behrent 2013). In this book, we notice how knowledge that reformed modern industrial organisations in the 1940s is embraced by contemporary higher education reform. Such parallels open up a range of critical questions, in terms of the effects of particular forms of governing through evaluation, on actors' subjectivities and their work and knowledge.

\section{Evaluation}

We see evaluation and quality assurance as closely related social processes. In our case, both involve making judgements and producing descriptions about higher education, and we therefore do not separate the two in a conceptual sense. It is also important to underline that these processes are, by definition, about assessment and judgement, and therefore heavily laden with values (House and Howe 1999). 
As noted above, our theoretical approach to governing acknowledges the work and "doings" of policy actors, as well as the importance of aims and directions for future achievements and/or projected future states. The basic rationale of evaluation encompasses assessments about the condition or worth of something (such as higher education), in order to provide an outline of how to move forward, hence the link to governing. Or as Mark and Henry put it: "the link between evaluation and the betterment of social conditions is absolutely crucial as a collective raison d'être of evaluation" (2004, p. 36, italics in original). This ambition can be organised and performed in several different ways, for example, by different types of evaluations and/or quality assurance activities/systems.

In this book, we will show that different EQA policies and practices rest on various epistemologies (Dahler-Larsen 2012a), meaning that they are designed and carried out in different ways and build on already existing knowledge. However, EQA also generates knowledge for formative purposes, be it development, improvement, control or accountability - all of them oriented to the future in a "rational" way. Furthermore, EQA entails actors, agencies, policies, places and work, in order to carry out the processes necessary, something we portray throughout the book. In these processes and activities, diverse forms of knowledge are in use, and produced, as already pointed out. In the processes of governing through knowledge, evaluation has also come to be understood as enclosing technologies such as visibility, comparability, sanctions and rewards, which have a productive capacity to shape behaviour, elicit action and even create new ways of being a HEI actor. Thus, through the work, and the knowledge that is activated, EQA also does something to what is evaluated, reviewed or assessed, and that can be understood as part of the governing. Dahler-Larsen (2012a, b) perceives this influence as "constitutive effects" and discusses how indicators are central to such influence (Dahler-Larsen 2012b, p. 173).

In EQA, indicators and/or standards play a significant role in directing attention, raising expectations and pointing out what is considered valuable, important and desirable and what quality (in higher education) consists of. Through indicators and standards, standardisation takes place and makes comparisons possible, something that is central for competition and choice in a market-oriented higher education system. At the same time, other issues become ignored. Dahler-Larsen (2014) claims that indicators/standards therefore represent and enhance particular views of education quality, defining interpretative frames and world views, content, time frames, social relations and identities, and change their meanings as a result of their use (Dahler-Larsen 2014). We will point to some of these potential constitutive effects that the Swedish EQA systems activate.

Over time, evaluation has evolved as a societal phenomenon and practice. From being a one-at-a-time rather delineated process, like programme evaluation, it has successively expanded in scope and comprehensiveness, over capacity building in organisations (e.g. Hueftle Stockhill et al. 2002; Preskill and Boyle 2008) to permanent systems with several interlinked evaluative activities (e.g. Segerholm 2006; Leeuw and Furubo 2008). Dahler-Larsen (2012a) likens this expansion to evaluation machines, claiming, among other things, that evaluation machines "embody a 
set of cultural values emphasising risk management, quantification, standards, and a pre-emptive or prospective approach to quality control" (2012a, p. 182). He continues to say that they "are comprehensive and general in coverage" and that "Reality must now become generally evaluable and thereby fit the demands of the evaluation machine" (ibid.). Finally, he argues that evaluation machines "seek to substitute subjective judgement for some objective evaluation based on standards, manuals, handbooks, procedures, or indicators" (ibid.). We will make use of this evaluation machine analogy in our explorations of evaluation as a practice of governing the Swedish higher education case and use the notion "evaluation machinery" to denote the assemblage of elements that these explorations identify.

\section{Outline of the Book}

In the forthcoming nine chapters, the reader will discern a movement from the more general to the rather detailed, as we shift our attention from broader historical and international developments to more thorough empirical accounts of contemporary affairs. The later chapters deliberately provide rather comprehensive accounts of evaluative systems and activities from our empirical data. We have intentionally strived to provide cautious and extensive empirical documentation, arguing that this holds an empirical value, in times of rapid restructuring and change. This book therefore moves from the general to the more detailed and attempts to cover different actors, organisations, analytical approaches and levels that, taken together and combined, provide a holistic account of EQA in Swedish higher education.

In the chapter "National Evaluation Systems" we set the national scene for our account about the recent policy and governing processes related to EQA in Swedish higher education. This is done through a historical perspective, in which we describe and analyse national EQA systems, their overall designs and some of their consequences from the 1990s to the 2011-2014 system. In the 1960s, national evaluations of higher education began to be conducted, and successively, national systems were developed. Through the different EQA systems, certain governing signals have been conveyed, making the HEIs used to external evaluation and to expect constant changes as new systems have been implemented. Systems changed, but with some variation over the period, and incorporated an increasing number of activities, people and higher education institutions, academic subjects and programmes. We discuss this in terms of an emerging and expanding "evaluation machinery" in Swedish higher education.

However, the EQA processes we are interested in are not merely restricted to the national but have extended to an international and European domain. In the third chapter "Europe in Sweden", our account of EQA in Swedish higher education therefore continues by extending the exploration to include the influx of European education and quality assurance policy to national policy in Sweden. Here, the ENQA's membership requirements played a significant role in the Swedish policy 
debate, which also illustrates Sweden's embeddedness in a wider policy context. In this chapter, we also describe and analyse the channels by which European policies are disseminated to and within Sweden, pointing to the different types of activities such dissemination processes involve. We discuss the role of the state in this EQA policy transfer and conclude that the number of different types of actors, both individuals and organisations, indicate that authority concerning higher education is, at the same time, dispersed and concentrated.

Chapter four "Navigating Higher Education Institutions in Times of Quality Assurance: The Assumptive Worlds of Vice Chancellors" moves from the international and European scene to the Swedish HEIs and the mindsets of an influential group of actors, the vice chancellors. As responsible for the quality assurance work of their HEIs, our interest was directed at their ideas of quality in higher education and of the idea of a university, as well as of the national EQA. Their ideas are described and analysed as parts of their "assumptive worlds" (Marshall, Mitchell and Wirt 1985), understood as a common ground constituting them as a potentially strong influencing force in these matters. The assumptive worlds of the vice chancellors included conflicting ideals, where old traditional ideas coexisted with newer ones adapted to meet global economic demands. In spite of this, they were able to join forces and act on their critique of the 2011-2014 national EQA system.

In the next chapter "Hayek and the Red Tape: The Politics of Evaluation and Quality Assurance Reform: From Shortcut Governing to Policy Rerouting", we draw attention to the important political dimension of the governing-evaluationknowledge nexus. We analyse the two most recent national EQA systems and show that the (re)construction of an evaluation machinery is far from neutral and uncontested process. We discuss how EQA systems are framed by certain ideological beliefs, manifested in their design as well as in the processes leading up to their design. We also highlight the style and speed of quality assurance policy development and point to the ways in which dialogue and consensus building in the 2016 EQA reform is positioned as countering the "shortcut" policy style characterising the development of the contested 2011-2014 EQA system.

The highly debated 2011-2014 national EQA system is further analysed in the chapter "Quality Evaluations and the Media" but approached from a different angle: the chapter analyses the intersection of high-stakes national higher education evaluations, media communication and PR strategies from the responsible agencies and HEIs. The study shows that the intense debate on the legitimacy of the 20112014 EQA system, during its implementation, was largely absent in the analysed media display of individual HEI evaluation results, as well as in the attempted framings and bureaucratic branding activities undertaken by the responsible agencies and the HEIs themselves. These results suggest that once the evaluation machinery is in operation, it becomes hard to criticise, and the formats of media communication, paired with logics of comparability and competition, may hamper critical debate.

In chapter seven "Enacting a National Reform Interval in Times of Uncertainty: Evaluation Gluttony Among the Willing", we turn to an exploration of reform activ- 
ities within four HEIs. This chapter offers an empirical illustration of the governingevaluation-knowledge nexus by pinpointing a particular situation: the time period between two national EQA reforms, when a new national EQA system was being planned and prepared, but its final design was not yet decided. We show how uncertainty during this "reform interval" opens up a potential space for policy-makers and HEIs to navigate. The results demonstrate that tendencies of homogenisation and isomorphism are strong among the four HEIs. Apparent is also the ongoing trend in terms of expansion, as the HEIs willingly dedicate resources to develop and engineer their internal quality assurance systems.

In the following two chapters, we scrutinise the relaunching and preparation of a national EQA system after the reform interval and the enactment of this 2016 system in the form of a pilot prior to its full-scale implementation at two HEIs. In the chapter "Re-launching National Evaluation and Quality Assurance: Expectations and Preparations", we describe and analyse the design work of this system as processes of governing. This work resulted in a very comprehensive system, with several different types of evaluations directed at most parts of the HEIs. Through the reintroduction of institutional reviews of the HEIs' own internal quality assurance systems, the new design was in itself an expansion compared to the previous system. Furthermore, the European EQA policy became firmly integrated in the design work. We discuss how this design emphasises the governing by objectives and outcomes logic, promote a certain notion of quality in higher education and suggest that this design opens up for potential constitutive effects.

Chapter nine "Re-launching National Evaluation and Quality Assurance: Governing by Piloting" explores and discusses enactments in the process of piloting institutional reviews. This chapter draws attention to two empirical cases and particularly the work and experiences of different actors within the SHEA, assessment panels and the HEIs under review. We demonstrate, in some detail, the amount and forms of work done in these processes, and the important role of what we have termed "qualocrats" in operating the evaluation machinery. Their embodied form of expertise is mobilised as they move between and across different domains, to enact and promote certain knowledge in and of EQA. The chapter goes on to suggest that the pilot opened up for mutual adjustments, learning and dialogue that worked in order to smoothen the subsequent broader implementation of the institutional reviews. At the same time, it also gave rise to uncertainty and contradictory anticipating governing signals.

In the final chapter "Evaluation Machinery, Qualocrats, and the Seemingly Inevitable Problem of Expansion", we highlight some of our observations on EQA policy and practice in Swedish higher education. We revisit the notion of an increasingly institutionalised evaluation machinery and discuss the role of qualocrats and judgements along with the expansion and increasing complexity of EQA work in higher education. 


\section{References}

Agius, C. (2007). Sweden's 2006 parliamentary election and after: Contesting or consolidating the Swedish model? Parliamentary Affairs, 60(4), 585-600.

Askling, B. (2012). Enhetlighet och/eller profilering i det svenska högskolelandskapet? [Uniformity and/or profiles in the Swedish higher education landscape]. Pedagogisk Forskning i Sverige, $17(1-2), 1-22$.

Aylott, N., \& Bolin, N. (2015). Polarising pluralism: The Swedish parliamentary election of September 2014. West European Politics, 38(3), 730-740.

Ball, S. J., Maguire, M., \& Braun, A. (2012). How schools do policy. Policy enactments in secondary schools. London: Routledge.

Barrow, M. (1999). Quality-management systems and dramaturgical compliance. Quality in Higher Education, 5(1), 27-36.

Bauer, M., Askling, B., Gerard Marton, S., \& Marton, F. (1999). Transforming universities. Changing patterns of governance, structure and learning in Swedish higher education. London/Philadelphia: Jessica Kingsley Publishers.

Beerkens, M. (2015). Quality assurance in the political context: In the midst of different expectations and conflicting goals. Quality in Higher Education, 21(3), 231-250.

Behrent, M. C. (2013). Foucault and technology. History and Technology, 29(1), 54-104.

Bevir, M. (2011). Public administration as storytelling. Public Administration, 89(1), 183-195.

Bevir, M. (2013). A theory of governance. Berkely: University of California Press.

Boje, D. M., \& Winsor, R. D. (1993). The resurrection of Taylorism: Total quality management's hidden agenda. Journal of Organizational Change Management, 6(4), 57-70.

Brady, N., \& Bates, A. (2016). The standards paradox: How quality assurance regimes can subvert teaching and learning in higher education. European Educational Research Journal, 15(2), 155-174.

Braithwaite, J. (2005). Neoliberalism or regulatory capitalism (RegNet Occasional Paper No. 5). Available at SSRN: https://ssrn.com/abstract=875789 or https://doi.org/10.2139/ssrn.875789

Brøgger, K. (2018). How education standards gain hegemonic power and become international: The case of higher education and the Bologna process. European Educational Research Journal, 1-23. https://doi.org/10.1177/1474904118790303.

Cai, Y., Pinheiro, R., Geschwind, L., \& Aarrevaara, T. (2016). Towards a novel conceptual framework for understanding mergers in higher education. European Journal of Higher Education, 6(1), 7-24.

Campano, G. (2011). Government continue to do its job: A comparative study of governance shifts in the higher education sector. Public Administration Journal, 89(4), 1622-1642.

Carlbaum, S., Hult, A., Lindgren, J., Novak, J., Rönnberg, L., \& Segerholm, C. (2014). Skolinspektion som styrning [School inspection as governing]. Utbildning \& Demokrati, 23(1), 5-2.

Clarke, J. (2015). Inspection: Governing at a distance. In S. Grek \& J. Lindgren (Eds.), Governing by inspection (pp. 11-26). London: Routledge.

Dahler-Larsen, P. (2012a). The evaluation society. Stanford: Stanford University Press.

Dahler-Larsen, P. (2012b). Constitutive effects as a social accomplishment: A qualitative study of the political in testing. Education Inquiry, 3(2), 171-186.

Dahler-Larsen, P. (2014). Constitutive effects of performance indicators. Getting beyond unintended consequences. Public Management Review, 16(7), 969-986.

Dahlstedt, M., \& Fejes, A. (Eds.). (2019). Neoliberalism and market forces in education: Lessons from Sweden. London: Routledge.

Dan $\varnothing$, T., \& Stensaker, B. (2007). Still balancing improvement and accountability in external quality assurance in the Nordic Countries 1996-2006. Quality in Higher Education, 13(1), 81-93.

Enders, J., \& Westerheijden, D. F. (2014). Quality assurance in the European policy arena. Policy and Society, 33(3), 167-176. 
Englund, T. (1993). Utbildning som "public good" eller "private good": Svensk skola i omvandling [Education as "public good" or "private good": Transformation of the Swedish School] (Pedagogisk forskning i Uppsala 108). Uppsala: Uppsala universitet,

Esping-Andersen, G. (1990). The three worlds of welfare capitalism. Cambridge, MA: Polity.

Freeman, R., \& Sturdy, S. (2015). Knowledge in policy: Embodied, inscribed, enacted. Bristol: Policy Press.

Fumasoli, T., Stensaker, B., \& Vukasovic, M. (2017). Tackling the multi-actor and multi-level complexity of European governance of knowledge: Transnational actors in focus. European Educational Research Journal, 17(3), 325-334.

Furubo, J.-E., \& Stame, N. (Eds.). (2019). The evaluation enterprise. A critical view. New York/ Abingdon: Routledge.

Geschwind, L., \& Forsberg, E. (2015). Forskning om högre utbildning: aktörer, miljöer och teman [Research on higher education: Actors, environments and themes]. Stockholm: Vetenskapsrådet.

Goodman, R., Kariya, T., \& Taylor, J. (Eds.). (2013). Higher education and the state. Changing relationships in Europe and East Asia. Oxford: Symposium Books.

Gornitzka, Å., Kogan, M., \& Amaral, A. (Eds.). (2007a). Reform and change in higher education. Analysing policy implementation. Dordrecht: Springer.

Gornitzka, Å., Kogan, M., \& Amaral, A. (2007b). Introduction. In Å. Gornitzka, M. Kogan, \& A. Amaral (Eds.), Reform and change in higher education. Analysing policy implementation (pp. 1-13). Dordrecht: Springer.

Government Bill 1992/93:1. Universitet och högskolor - frihet för kvalitet [University and university colleges - freedom for quality]. Stockholm: Utbildningsdepartementet.

Government Bill 2004/05:162. Ny värld - ny högskola [New world - new higher education]. Stockholm: Utbildningsdepartementet.

Government Bill 2009/10:149. En akademi i tiden - ökad frihet för universitet och högskolor [A contemporary academy - Increased freedom for universities and university colleges]. Stockholm: Utbildningsdepartementet.

Government Offices of Sweden. (2017). Brett deltagande i högskoleutbildning [Widening reqruitment in higher education] (Promemoria 2017-07-18). Stockholm: Regeringskansliet.

Grek, S., \& Lindgren, J. (Eds.). (2015). Governing by inspection. London: Routledge.

Gröjer, A. (2004). Den utvärdera(n)de staten [The evaluative state]. Stockholm University: Department of Political Science.

Herbst, M. (2009). Financing public universities. Dordrecht: Springer.

House, E. R. (1993). Professional evaluation. Social impact and political consequences. Newbury Park: SAGE.

House, E. R., \& Howe, K. (1999). Values in evaluation and social research. Thousand Oaks/ London/New Delhi: SAGE.

Hueftle Stockhill, S., Baizerman, M., \& Compton, D. W. (2002). Toward a definition of the ECB process: A conversation with the ECB literature. New Directions for Evaluation, 93, 7-25.

Jacobsson, B. (2010, June). Making sense of Europeanization. Jerusalem papers in regulation \& governance (Working Paper No. 11). Jerusalem: The Hebrew University, Jerusalem Forum on Regulation \& Governance.

Jacobsson, B., Pierre, J., \& Sundström, G. (2015). Governing the embedded state. The organizational dimension of governance. Oxford: Oxford University Press.

Jarvis, D. S. L. (2014). Regulating higher education: Quality assurance and neo-liberal managerialism in higher education - A critical introduction. Policy \& Society, 33, 155-166.

Jessop, B. (2015). The state: Past, present, future. Cambridge, MA: Polity Press.

Karlsohn, T. (Ed.). (2016). Universitetets idé. Sexton nyckeltexter [The idea of a university. Sixteen key texts]. Gothenburg: Daidalos.

Karlsson Vestman, O. (2011). Utvärderandets konst [The art of evaluation]. Lund: Studentlitteratur.

Karlsson, S., Fogelberg, K., Kettis, Å., Lindgren, S., Sandoff, M., \& Geschwind, L. (2014). Not just another evaluation: A comparative study of four educational quality projects at Swedish universities. Tertiary Education and Management, 20(3), 239-251. 
Kettis, Å., \& Lindberg-Sand, Å. (2013). Kvalitetssystemets kval. En dialog från olika utgångspunkter. [The qualms of the national system for quality assurance. A dialouge from different viewpoints]. Högre utbildning, 3(2), 139-149.

Larsson, B., Letell, M., \& Thörn, H. (Eds.). (2012a). Transformations of the Swedish Welfare State. From social engineering to governance? Basingstoke/New York: Palgrave Macmillian.

Larsson, B., Letell, M., \& Thörn, H. (2012b). Transformations of the Swedish Welfare State: Social engineering, governance and governmentality. In B. Larsson, M. Letell, \& H. Thörn (Eds.), Transformations of the Swedish Welfare State. From social engineering to governance? (pp. 3-22). Basingstoke/New York: Palgrave Macmillian.

Latour, B., \& Woolgar, S. (1979). Laboratory life. The construction of scientific facts. Beverly Hills: Sage.

Leeuw, F. L., \& Furubo, J.-E. (2008). Evaluation systems. What are they and why study them? Evaluation, 14(2), 157-169.

Leiber, T., Stensaker, B., \& Harvey, L. (2015). Impact evaluation of quality assurance in higher education: Methodology and causal designs. Quality in Higher Education, 21(3), 288-311.

Levi-Faur, D. (2017). Regulatory capitalism. In P. Drahos (Ed.), Regulatory theory. Foundations and applications. Acton: ANU Press. http://press-files.ana.edu.au/downloads/press/n2304/pdf/ book.pdf?referer $=2304$.

Lewin, L. (2002). "Bråka inte!" Om vår tids demokratisyn. ["Do not fight!” about our contemporary view on democracy]. Stockholm: SNS.

Lingard, B., \& Rawolle, S. (2011). New scalar politics: Implications for education policy. Comparative Education, 47(4), 489-502.

Lindgren, L. (2012). En utvärderare om Högskoleverkets system för kvalitetsutvärdering 20112014 [An evaluator reflecting on the 2011-2014 national evaluations in higher education]. Statsvetenskaplig tidskrift, 114(3), 471-482.

Mark, M. M., \& Henry, G. (2004). The mechanisms and outcomes of evaluation influence. Evaluation, 10(1), 35-57.

Massey, D. (2013). Doreen Massey on space. Podcast interview by Nigel Warburton for Social Science Bites. Retrieved from https://www.socialsciencespace.com/2013/02/ podcastdoreen-massey-on-space/

Marshall, C., Mitchell, D. E., \& Wirt, F. (1985). Assumptive worlds of education policy makers. Peabody Journal of Education, 62(4), 90-115.

Merriam-Webster Dictionary. (n.d.). https://www.merriam-webster.com/dictionary/nexus

Molander, A. (2016). Discretion in the welfare state. Social rights and professional judgement. London: Routledge.

Neave, G. (1998). The evaluative state revisited: 20th anniversary issue of review of trends in higher education. European Journal of Education, 33(3), 265-284.

Normand, R. (2016). Epistemic governance of European education. The fabrication of the Homo Academicus Europeanus? Dordrecht: Springer.

Olssen, M., \& Peters, M. A. (2005). Neoliberalism, higher education and the knowledge economy: From the free market to knowledge capitalism. Journal of Education Policy, 20(3), 313-345.

Oxford Dictionaries. (n.d.). https://en.oxforddictionaries.com/definition/nexus

Ozga, J. (2016). Trust in numbers? Digital education governance and the inspection process. European Educational Research Journal, 15(1), 69-81.

Ozga, J., \& Lingard, B. (2006). Globalisation, education policy and politics. In B. Lingard \& J. Ozga (Eds.), The Routledge Falmer reader in education policy and politics (pp. 65-82). London: Routledge.

Ozga, J., Dahler-Larsen, P., Segerholm, C., \& Simola, H. (Eds.). (2011). Fabricating quality in education. Data and governance in Europe. New York/London: Routledge.

Paradeise, C., \& Thoenig, J. C. (2013). Academic institutions in search for quality. Local orders and global standards. Organization Studies, 34(2), 189-218.

Parliament Standing Committee on Education 2005/06:UbU3. Ny värld - ny högskola [New world - new higher education]. Stockholm: Riksdagen. 
Pierre, J. (2004). Central agencies in Sweden: A report from utopia. In C. Pollitt \& C. Talbot (Eds.), Unbundled government. A critical analysis of the global trend to agencies, quangos and contractualisation (pp. 203-215). London: Routledge.

Pierre, J., \& Peters, B. G. (2000). Governance, politics and the state. Basingstoke: Macmillan.

Pollitt, C. (1995). Justification by works of by faith? Evaluating the new public management. Evaluation, 1(2), 133-154.

Pratasavitskaya, H., \& Stensaker, B. (2010). Quality management in higher education: Towards a better understanding of an emerging field. Quality in Higher Education, 16(1), 37-50.

Preskill, H., \& Boyle, S. (2008). A multidisciplinary model of evaluation capacity building. American Journal of Evaluation, 29(4), 443-459.

Rhodes, R. A. W. (2007). Understanding governance: Ten years on. Organization Studies, 28(8), $1243-1264$.

Rider, S., Hasselberg, Y., \& Waluszelwski, A. (Eds.). (2013). Transformations in research, higher education and the academic market. The breakdown of scientific thought. Dordrecht: Springer.

Rosa, M. J., \& Amaral, A. (Eds.). (2014). Quality Assurance in Higher Education. Contemporary debates. London: Palgrave.

Rothstein, B. (1992). Explaining Swedish corporatism: The formative moment. Scandinavian Political Studies, 15(3), 173-191.

Rothstein, B. (2005). Från ämbetsverk till ideologiska statsapparater [From government offices to ideological state apparatuses]. In B. Rothstein, \& L. Vahlne Wästerhäll (Eds.), Bortom den starka statens politik [Beyond the politics of the strong state] (pp. 186-221). Stockholm: SNS.

Salter, B., \& Tapper, T. (2000). The politics of governance in higher education: The case of quality assurance. Political Studies, 48, 66-87.

Sassen, S. (2007). A sociology of globalisation. London/New York: W W Norton.

Schuetze, H. G., Bruneau, W., \& Grosjean, G. (Eds.). (2012). University governance and reform. Policy, fads, and experience in international perspective. New York: Palgrave Macmillian.

Scott, J. C. (1998). Seeing like a state. How certain schemes to improve the human condition have failed. New Haven: Yale University Press.

Segerholm, C. (2006, November 1-4). Evaluation and the pace of change - An exploration of consequences. Paper presented at the American Evaluation Association conference in Portland.

SFS 1992:100. (n.d.). Högskoleförordning [The Higher Education Ordinance].

SFS 1992:1434. (n.d.). Högskolelag [The Higher Education Act].

Shattock, M. (Ed.). (2014). International trends in university governance. autonomy, selfgovernment and the distribution of authority. New York/London: Routledge.

SHEA. (2018). Higher education in Sweden - 2018 status report. Stockholm: UKÄ.

Sultana, R. G. (2012). Higher education governance: A critical mapping of key themes and issues. European Journal of Higher Education, 2(4), 345-369.

Therborn, G. (1995). European Modernity and Beyond. The trajectory of the European societies 1945-2000. New Delhi/London/Thousand Oaks: SAGE.

Thörn, H., \& Larsson, B. (2012). Conclusions. Re-engineering the Swedish welfare state. In B. Larsson, M. Letell, \& H. Thörn (Eds.), Transformations of the Swedish Welfare State. From social engineering to governance? (pp. 262-282). Basingstoke/New York: Palgrave Macmillian.

Toots, A., \& Kalev, L. (2016). Governing in the shadow of Bologna: Return of the state in higher education quality assurance policy. International Journal of Public Policy, 12(1-2), 54-70.

Travers, M. (2007). The new bureaucracy. Quality assurance and its critics. Bristol: The Policy Press.

Wedlin, L. (2011). Mål och resultatstyrning för högre utbildning och forskning - en kunskapsöversikt. Rapport till MOR, RJ [Governing by objectives/goals and outcomes/results in higher education and research - A research review. Report to MOR, The Swedish Foundation for Humanities and Social Sciences]. http://www.rj.se/1/130/var/newsID/478, Retrieved February 2012. 
Wedlin, L., Pallas, J., Ahlbäck Öberg, S., Bomark, N., \& Edlund, P. (2017). Det ostyrda universitetet. Perspektiv på styrning, autonomi och reform av svenska lärosäten [The ungoverned university. Perspectives on governing, autonomy and reformed Swedish HEIs]. Göteborg: Makadam.

Westerheijden, D. F., Stensaker, B., \& Rosa, M. J. (Eds.). (2007). Quality assurance in higher education: Trends in regulation, translation and transformation. Dordrecht: Springer.

Wiktionary. (n.d.). https://en.wiktionary.org/wiki/nexus

Open Access This chapter is licensed under the terms of the Creative Commons Attribution 4.0 International License (http://creativecommons.org/licenses/by/4.0/), which permits use, sharing, adaptation, distribution and reproduction in any medium or format, as long as you give appropriate credit to the original author(s) and the source, provide a link to the Creative Commons license and indicate if changes were made.

The images or other third party material in this chapter are included in the chapter's Creative Commons license, unless indicated otherwise in a credit line to the material. If material is not included in the chapter's Creative Commons license and your intended use is not permitted by statutory regulation or exceeds the permitted use, you will need to obtain permission directly from the copyright holder.

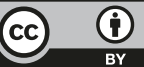




\title{
National Evaluation Systems
}

\author{
Christina Segerholm and Joakim Lindgren
}

\begin{abstract}
The national reform context for evaluation and quality assurance (EQA) in Swedish higher education along with the designs of the different national EQA systems during 1995-2014 is described and analysed in this chapter. This historical account establishes the background for the coming chapters in the book. Our aim is to scrutinise the relationship between the EQA systems and governing. We used government bills, official reports, research reports, articles, and books to describe and analyse the different policy contexts and EQA systems. In the analysis, we observe shifts and continuities as institutional reproduction and change. In this chapter, we also discuss governing in terms of the different expectations raised by the national EQA systems and liken the historical expansion of the systems to an evaluation machinery.
\end{abstract}

\section{Introduction}

This chapter, in addition to forming the background for the coming chapters in this book, contextualises the Swedish national evaluation and quality assurance (EQA) systems and explicates their national reform contexts. ${ }^{1}$ Higher education is an area that European and global policy efforts have greatly influenced in recent years. The Bologna declaration and the joint work on developing common indicators for assessing quality in higher education are far-reaching examples of such policy work. In parallel with other policy areas, the contemporary education policy strongly promotes the idea of systematic EQA and is part of what Power (1997) has discussed

${ }^{1}$ This text is a revision and extension of Segerholm et al. 2014.

C. Segerholm $(\square)$

Department of Education, Umeå University, Umeå, Sweden

e-mail: christina.segerholm@umu.se

J. Lindgren

Department of Applied Educational Science, Umeå University, Umeå, Sweden

e-mail: joakim.lindgren@umu.se

C. Segerholm et al. (eds.), The Governing-Evaluation-Knowledge Nexus,

Evaluating Education: Normative Systems and Institutional Practices,

https://doi.org/10.1007/978-3-030-21143-1_2 
as the "audit society", Dahler-Larsen (2012) as the "evaluation society", and Neave (1998) as the "evaluative state". These European policy efforts have also influenced the Swedish national context. Thus, we recognise the importance of global and European influences (see, e.g. Ozga et al. 2011; Grek and Lindgren 2015), but in this chapter, we concentrate on exploring the relationship between national EQA systems and governing in the Swedish context. This account, we believe, can provide insight also into how changes in other countries' EQA systems are part of the contemporary governing of higher education.

Over the last few decades in Swedish higher education, various national EQA systems have been decided, developed, and put into effect. Over time, these systems have displayed diverse political purposes and directions and exhibited different designs. The ramifications for the EQA systems that emerged from the policy context and the design of these systems form parts of the complex and comprehensive work of governing. Here, our objective is to provide a historical account and describe and analyse the national EQA systems for higher education, their designs from 1995 to the 2011-2014 system, and their relation to governing. We explore the political process leading up to the 2016 system in the chapter "Hayek and the Red Tape: The Politics of Evaluation and Quality Assurance Reform - From Shortcut Governing to Policy Rerouting" and scrutinise this system in detail in the chapter "Re-launching National Evaluation and Quality Assurance: Expectations and Preparations".

In this chapter, the following questions directed our analysis and also organised our presentation of the national EQA systems:

- What is being evaluated? Why? By whom? How? What are the consequences in terms of expectations?

- What are the implications for higher education governing?

In the following, we present a theoretical frame for our understanding of the different national EQA systems that have evolved over the past 25 years. Thereafter, we describe the major reforms in Swedish higher education as a context for the design and use of the EQA systems. We divide this description into the periods the respective designs were in operation. Finally, we discuss the EQA systems in relation to governing by expectations and inductively based on Dahler-Larsen's (2012) idea of evaluation machines (see next section).

\section{A Theoretical Approach to Evolving National Evaluation Systems}

As stated in the first chapter, we understand governing as a verb and emphasise the work carried out in different ways by different actors in diverse places and spaces and by various means to reach certain aims (Clarke 2015). Policy intentions and aims are expressed in several policy documents and reforms, and for EQA systems, such intentions are also embedded in their designs or "infrastructures of rules" 
(Fourcade 2010, pp. 571-572). The designs prescribe what is to be done (what is to be evaluated, how, by whom, and for what reasons [what is hoped to be achieved]), orient the attention of those taking part in these processes, and influence their behaviours, activities, and perceptions of their enterprises (Dahler-Larsen 2014; Segerholm 2001).

For the purpose of this chapter, we recognise the dynamic relationship underlying both institutional reproduction and change (Mahoney and Thelen 2010). Change does not necessarily need to encompass the whole institution but can target and influence parts of it. EQA systems may change gradually or more dramatically, and these dynamics hold implications not only for governing but also for our understanding of expectations of what should count as, for instance, "good quality" (Hopmann et al. 2007). Thelen (2003, p. 213) argues that models of path dependency, accompanied by change as rapid and drastic punctuations, need to be complemented by other tools that enable us to account for a more gradual and dynamic relationship, as these processes may be more incremental than usually proposed. Departing from such an understanding of stability versus change, we use a set of concepts that capture this dynamic in different ways.

First, conversion, marking a change originating from within the institution itself when existing frameworks come to be enacted in various ways, resulting in institutions' reorientation towards new goals or missions. If new rules and procedures that originate from outside the institution are put into place, the concept of displacement refers to both more radical exogenous alterations, as well as slow, incremental processes of change. Institutional layering marks a gradual process of change, involving revisions, additions, and modifications when new elements are added to and put alongside old ones. Each revision may be small, but when placed alongside one another, they accumulate and result in a fundamental change. Institutions also face the risk of drift, erosion stemming from an incapacity to respond to the external context. Another such risk is exhaustion by slow-moving breakdown, resulting in self-destruction from within (Mahoney and Thelen 2010; Thelen 2000, 2003). We use these concepts as analytical descriptors of the evolving national EQA systems.

We relate to the idea of a governing - evaluation - knowledge nexus in that the notion of "evaluation machines" (Dahler-Larsen 2012, pp. 176-182) is used as a basis to discuss the expansion of the EQA systems over time. Evaluation systems may be conceived as evaluation machines, since they are being based on "distinctive epistemological perspectives", "organisational responsibility", "permanence", and "focus on the intended use of evaluations" (Dahler-Larsen 2012; Leeuw and Furubo 2008, pp. 159-160). We will elaborate on the evaluation machine metaphor further in the discussion.

Our account is based on documentary materials, such as government bills, official reports, and descriptions of the EQA systems, by the two national agencies responsible for higher education during the periods. We also use secondary sources such as research reports, articles, and books that describe and analyse the different policy contexts, and EQA systems in higher education in Sweden. 


\section{Shifting Policy Contexts: Continuities and Shifts in Evaluation Designs}

In this section, we present continuities and shifts in Sweden's higher education policies, along with the variety of national EQA systems designs that emerges from 1995 to the system decided in 2016. We find that descriptions of the major reforms are contextual information that is necessary for understanding the EQA systems' designs. The periods slightly extend into each other since the termination of one system overlaps with the introduction of a new one. Before we go into this presentation, we offer a short background on the history of EQA in Sweden.

\section{$-1994$}

External evaluation is a rather new phenomenon within the landscape of Swedish higher education institutions (HEI). From 1477, the formation of the first university in Uppsala, up until the 1960s, institutionalised forms of external evaluation did not exist. According to Gröjer (2004; see also Neave 1998), external evaluation was a response to problems related to the expansion of higher education, and to the transformation from an elite institution to a mass university. From 1950 to 1960, the higher education system expanded from 16,400 students to 37,000, and by 1970 , the number had increased to 130,000 (Gröjer 2004, p. 50). This expansion involved not only new groups of students but also new HEIs, staff, programmes, etc., and external evaluation was perceived as a state instrument to retrieve knowledge that could be used to plan, steer, and improve the sector according to contemporary utopian and rationalistic ideas. Notably, the first national agency (Universitetskanslersämbetet, UKÄ), which was installed in 1964 and was responsible for planning and sizing, focused its first evaluations on issues on pedagogical aspects such as improvement in teaching and examination. The 1970s saw the emergence of the idea that evaluation could be used at a national system level in order to control whether national goals were attained. Not only examination frequencies, i.e. output, were used, but also data on the inner workings of HEIs in terms of teaching, examination, students' previous knowledge, study habits, teachers' working conditions, etc. were acknowledged. As Gröjer (2004) noted, "effective development could only be achieved if the entire education system was scanned and evaluated" (p. 64). Thus, evaluation originally served the purpose of making the inner world of higher education "visible" to the state. External experts and agency staff who used implicit professional standards and indicators conducted the evaluations, and methods were adapted contextually without any overall agency policy governing the assessments. Information from the evaluations did not follow any explicit official plan but was still distributed to those who were affected (Gröjer 2004). In 1977, a higher education reform informed by ideas on decentralisation and management by objectives called for further national evaluations. The new national agency 
(Universitets- och högskoleämbetet, UḦ̈) engaged independent researchers and started building networks to facilitate exchanges of experiences and ideas. Conferences, seminars, and information were also used to develop evaluation practices.

According to Gröjer (2004), notions of inefficiency within the higher education sector in the 1980s made evaluations increasingly important. Components like site visits, peer reviews, and criteria for international comparisons were implemented and methods developed. However, HEIs still held responsibility for teaching quality and education results, whereas EQA served to control quality at the national level. At the end of the 1980s, the concept of "quality" began to manifest itself within the language of EQA, and the perspectives of new groups of actors including students, student unions, and representatives from the working life (like potential employers) were introduced in the evaluations. The purpose of the evaluations was both to improve and control; however EQA was still based on implicit criteria and a group of directly involved experts who, based on their professional discretion, designed and implemented each evaluation (Gröjer 2004). Gröjer (2004) describes a continuous process of professionalization for the evaluative activities during this period. In this process, specific knowledge was developed, for example, during site visits where actors had the opportunity to learn from each other. Increasingly also, the national agency (UHÄ) argued that the HEIs must use the evaluation results for the purpose of improvement.

\section{5-2001}

The overall aims of the higher education reform of 1993 were to increase the freedom of HEIs, to establish incentives for quality development, and to improve efficiency in the use of resources in HEI activities. This reform also dramatically changed the preconditions for HEIs since the entire state allocation system was altered to a governing system based on economic incentives and productivity (Bauer et al. 1999; Government Bill 1992/1993:1). A performance-based funding system (Herbst 2009) based on a per-student state grant system was introduced, with one sum for each registered student and a larger sum for each student passing the course requirements. This meant that the previous system of applying for state grants in relation to the number of students was abandoned, as well as the applications for funds to install professorships and senior lecturers, that when approved, were granted by royal letters. Another novelty compared to the central planning in the 1960s was local freedom for the HEIs to decide on educational content in their courses and programmes. Specific national/state requirements were however still in operation for professional programmes (e.g. teacher education, physicians). Internal quality assurance (IQA) systems at the HEIs were also introduced as a mandatory requirement along with a demand for obligatory course evaluations (Bauer et al. 1999; Government Bill 1992/1993:1). 
The design of the national EQA system during this period, it was argued, was to stimulate internal quality work in order to uphold and enhance quality. A new national agency, the Swedish National Agency for Higher Education (SNAHE, Högskoleverket), was established with the commission to push and control the HEIs' work with quality issues (Government Bill 1992/1993:1). In line with these motives, the design of the EQA system was directed at the HEIs' internal quality assurance work, leaving it to the HEIs to decide how this was to be carried out. The SNAHE carried out two cycles of these types of evaluations (SNAHE 1998). Another part of the EQA system was directed towards accreditation for awarding magister degrees. Both these evaluation types were performed in a similar way, by a so-called self-evaluation based on a particular national template, peer review with a site visit carried out by external colleagues, plus a public report. The process as a whole was administered by the SNAHE. All HEIs were evaluated in 3-year cycles. During this period, with the 1993 years reform as a starting point, recurring external control of higher education through a national EQA system was introduced for the first time in Sweden.

\section{1-2007}

No major national quality assurance reform was decided during this period, but some substantial changes were nevertheless made regarding the design of the national EQA system. The system was now said to be a means to guarantee a minimum standard in the education provided, to enhance trust in HEIs, to increase student influence, and to serve students with information so they can make informed choices (Government Bill 1999/2000:28).

The design of the EQA system shifted its focus to be directed to quality in education, that is, evaluation of the quality in academic subject courses and programmes (Government Bill 1999/2000:28; Franke and Nitzler 2008). Another part of the design was to include thematic evaluations, which were directed at, for example, student influence and diversity. Accreditation for rewarding degrees and certificates and of so-called scientific areas (e.g. the right for a university college to establish PhD programmes and award doctoral degrees) was another part. All types of evaluations were carried out in line with a local evaluation model developed in the 1980s by Sigbrit Franke-Wikberg (1990), who at this time was the director general of the SNAHE. The model was adapted to serve a national perspective and consisted of a self-evaluation based on a national template. The template for the subject and programme evaluations asked the responsible department for information about three aspects: preconditions for courses and programmes, the education processes, and the outcomes of the education processes (SNAHE 2001, 2003). The template emphasised preconditions such as number of faculty with $\mathrm{PhD}$, their positions, and number of enrolled students. The three aspects were then to be related to one another in an analysis and an assessment of the education the departments provided. A selfevaluation report was sent to the SNAHE, and the work with it was supposed to 
engage the whole faculty in an internal discussion of their work. A group of subject/ programme experts carried out a peer review, and for the first time, students were part of this external evaluation group. The peer-review group made site visits and conducted interviews with department heads and managers, teachers/researchers, and students. The group produced a written public report in which the SNAHE included their decision on whether the education was assessed to be of sufficient quality. Hence, the reviewers had to provide a cut score that encapsulated their judgement and formed the basis for the SNAHE's decision. Sanctions were also introduced with this EQA system, meaning that if the department/HEI did not improve, the right to award degrees or certificates could be revoked. A follow-up was therefore performed a year after in cases of a decision of inadequate quality. This happened very rarely (Wahlén 2012), but the entire base for HEIs to provide a certain level of education (course or programme) could be in jeopardy because the state grants regulated in the 1993 reform were (and still are in 2019) coupled to the right to award degrees. This EQA system was run in a 6-year cycle, and the intention was to include all academic subjects and programmes.

During this period, the HEIs had to evaluate their educational quality in line with the national template and had to yield to assessments conducted by an external group of "colleagues" including students. To adapt to these new circumstances and support departments in their work with self-evaluations, many HEIs expanded their administrations with new functions such as "quality officers" at the faculty level and deputy vice-chancellors with education quality as a particular responsibility at the central level (Segerholm and Åström 2007). The number of evaluations that the universities and departments had to engage in increased substantially with this rather extensive system, and there were signs that the previously existing internal evaluation models gave way to the national model and its templates (Segerholm and Åström 2007). There were also signs of evaluation influence, before an actual evaluation process had even started; for example, several signs showed that the attention of the HEIs was directed at what was asked for in the national template, and not what had locally been prioritised previously (Segerholm and Åström 2007).

\section{7-2011}

The major change in preconditions for higher education during this period was the so-called Bologna reform in 2007. The entire structure for Swedish higher education was altered to include three levels (undergraduate, advanced, and graduate) rather than two (undergraduate and graduate). This system introduced a new order for degrees and certificates that required students to achieve learning outcomes to get a degree/certificate. Subsequently, specified learning objectives for all individual courses were now also required. Another novelty was the establishment of the term "subject areas" (i.e. either an academic subject or composite of related academic subjects) compared to the previous, more strict division in academic subjects (e.g. political science, sociology, and psychology). At the end of this period, the 
government decided on a new national agency that should exclusively supervise and evaluate higher education, the Swedish Higher Education Authority (SHEA, Universitetskanslersämbetet).

The design of the national EQA system stayed rather much the same but with some stress on the relationship between the learning objectives (i.e. the requirements for passing an individual course) and the learning outcomes (i.e. the requirements for a degree/certificate) (SNAHE 2007). Evaluations of the IQA systems at the HEIs were reintroduced and followed the European Association for Quality Assurance in Higher Education's (ENQA) recommendations (Ministry of Education 2009; SNAHE 2007). The subject and programme evaluations were to be proportionate based on a simplified national self-evaluation template. Those who seemed to live up to the quality requirements were to be evaluated less extensively (i.e. no site visits). The introduction of rewards (a distinction for an eminent educational environment) to departments that delivered "good quality" education was a new feature in this period (ibid.).

The design of the EQA system more or less emphasised the constant presence of external control but also directed some attention to the general idea of the relationship between (learning) objectives and outcomes. This system also represents a mix of sticks and carrots (i.e. threats to withdraw degrees and quality rewards) as a way to stimulate, or force, the HEIs to adapt to the new conditions.

\section{1-2014}

Swedish higher education in the last period covered in this chapter was influenced by all previous reforms, which were layered on top of each other since none of them had been dramatically challenged or altered (Thelen 2003). There was a kind of incremental process towards a higher education system that became more and more characterised by New Public Management (see Pollitt 1995, Pollitt and Bouckeart 2017). As an additional step in this direction, the government decided on what has come to be called the "autonomy reform" in 2010 (Government Bill 2009/2010:149). This reform concerned local freedom for the HEIs to organise internally, make decisions on types of positions and requirements for employment, and allocate resources internally at their own discretion. Just before this autonomy reform, the government, after a tense conflict with the SNAHE, decided to reform the design of the national EQA system (Government Bill 2009/2010:139). Its results-oriented design was thereafter severely critiqued (see, e.g. Kettis and Lindberg-Sand 2013); we will return to some of the reasons for this in the coming chapters. The SHEA's membership in the ENQA was revoked because this system did not fully adhere to the ENQA statutes, and the system was finally terminated. The last evaluations in the system were carried out in spring 2014, and the final public reports were published in 2016.

When the design of this EQA system was decided upon, it was justified in the policy texts by the need to increase quality in higher education (Government Bill 
2009/2010:139). Sweden, it was argued, also needed to strengthen its international position in the global economy and education market. A third motive was the need to clarify education quality in relation to the students and to the society at large. As in the 2007-2011 system, it was quality in education, that is, in subject areas (the new term introduced earlier) that should be evaluated. Also, as in previous systems, accreditation for the right to award degrees and certificates was part of the design. The dramatic change concerned how quality in education should be evaluated: from a model where the relations between preconditions for education, the process, and the outcomes/results were the basis for assessing quality, to a new evaluation model decided by the government. (This decision was in itself quite unique, because the responsible national authority normally makes such detailed decisions.) This design was product oriented (Franke-Wikberg and Lundgren 1980, 1981; House 1978) and mainly directed to assess student outcomes as measured through the indicator of students' independent projects (in the social sciences often limited empirically based studies presented as a small thesis/report). As before, a mandatory selfevaluation, in line with a national template asked for student grades, share that passed, etc. Quality assessment was delegated to an expert panel of peers, students, and representatives from areas external to the HEIs such as private companies or from the public sector. A sample of students' independent projects for the bachelor, magister, and master degrees, the self-evaluation, and video interviews with department representatives, teachers, and students (instead of site visits) formed the basis for the assessments (SNAHE 2010, 2012, 2013). The external panel produced a public report including the SHEA's decision. If the SHEA decided that the quality was insufficient, a plan for improvement was requested and a follow-up conducted. Sanctions were the same as before, but the carrots were resource allocation by state grants partly related to the assessment of quality (Government Bill 2009/2010:139). The political focus on "quality" during this period can be observed in the government bill (Government Bill 2009/2010:139) in which the design was proposed: The term "quality" alone or in connection with other terms appears eight times per page as a mean (Segerholm 2010), without being given any substantial meaning apart from student outcomes as measured by assessing students' independent projects for the bachelor, magister, and master degrees.

As we will see in the chapter "Hayek and the Red Tape: The Politics of Evaluation and Quality Assurance Reform - From Shortcut Governing to Policy Rerouting", the design of the national EQA system in this period marks a turn in evaluation ideology in two important ways. Firstly, the system is deliberately based on ideas regarding autonomy in the sense that it steers evaluation away from preconditions and education processes in an attempt to not interfere with the internal work of HEIs. Secondly, it involved a mode of governing by evaluation in which the government, by rather harsh means, forced a totally different model on the HEIs - a design based basically on the relationship between expected learning outcomes for a particular degree and student outcomes as measured by assessing students' independent projects. The stress was clearly on what has been labelled as evaluation of effects (results), which were quite independent of education and/or learning process and preconditions. There are examples, however, where the self-evaluation reports 
were given more weight in the evaluations. This slightly increased stress on self-evaluations was something that occurred during the period, much as a response to the criticism from the HEIs, as we understand it. The emphasis on evaluation of effects is also visible in the composition of the external panels, where HEI external representatives (or potential employers) were now for the first time acting as evaluators.

\section{Discussion}

In this chapter, we have described the major reforms in Swedish higher education and how the national EQA systems have been designed, used, and influenced HEIs. We have noted reproduction as well as change in the relatively short history of EQA in Sweden. Many components of systems in terms of design (e.g. peer reviews, selfevaluations, site visits, public reports) are introduced in the 1980s and 1990s as EQA was amplified on a broad national scale, and these were later complemented by additional components (e.g. thematic evaluations, accreditation) that were combined in different ways over time producing new aggregate system designs. We thus identify an overall process of expansion and change in the comprehensiveness of the various EQA system designs over time. The designs developed from a rather limited scope in direction as late as the 1990s, including evaluation of the HEIs' IQA systems and accreditation, over a very comprehensive design including at a minimum quality evaluations, thematic evaluations, and accreditation, to some intermediate state in the 2011-2014 period. The result of these developments in which the designs of the different EQA systems are layered over one another, mixing and blending new parts with the old and, when combined, results in a reorientation (Mahoney and Thelen 2010).

Moreover, ways of organising designs by way of technologies like visibility, comparability, economic rewards, and sanctions that foster and trigger certain modes of behaviour have been added over time. Such technologies are productive from an organisational perspective in the sense that they make things happen, and they also have a radical impact on the ways individual components are employed. For example, if the quality of HEIs is to be comparable on the basis of public reports, these must be reliable and comparable to all others of a similar kind. A public report that is part of an EQA system and explicitly serves the purpose of comparability thus puts increasing demands on methods and ways of writing in terms of validity and reliability. Such issues related to changes in EQA designs and the implications of such changes on practices and behaviours will be explored more in the upcoming chapters of the book. 


\section{Governing by Changing Designs}

The issue of change is interesting in different ways. First of all, changes in national EQA systems do not come about by themselves; each reform involves a political process and agency work, to plan, design, and implement new system parts and ways of organising them. Change thus produces fundamental shifts in the work of actors directly involved in evaluations. Our results therefore raise questions about whether the governing potential in the EQA systems in the Swedish case partly relies on the shifts themselves. By constantly changing the systems, expectations are also changed and form one important part of the work of governing. While change in EQA systems serves to produce change (i.e. improvement) within HEIs as new aspects of practices are evaluated over time, this change arguably also produce social acceleration (Rosa 2013) since each new national system brings about time-consuming efforts within the HEIs in terms of interpretation and translation (Ball et al. 2012) - efforts that are not only related to concrete practices of dealing with evaluations but also related to core activities such as organisation, planning, teaching, and examination.

Overall, our account confirms Hopmann's (2008) thesis that higher education over the last two decades has moved from being an internally managed "ill-defined problem" (evaluated by professionals themselves who needed leeway to define their own practice) to a "well-defined problem" that is managed and controlled by external (and internal) "expertise" by way of using indicators and standards. According to Hopmann (2008): "Expectation management changes [higher education] dramatically. The core focus shifts to more or less well-defined expectations of what has to be achieved by whom" (p. 424).

Although we recognise that European (and global) EQA policy interacts with the Sweden's national policy, the results also show that references regarding EQA design are formed rather endogenously through the social and institutional contexts in which the interactions are established. One observation is that the overall picture of the changes in the national EQA systems in terms of Mahoney and Thelen (2010; Thelen 2000, 2003) can be identified as institutional layering. However, over time there is also an ongoing process of displacement that has changed the entire direction of Swedish higher education through the different designs of EQA systems and particularly the various kinds of evaluation models. Displacement here involves fundamental change through more active interventions in prior arrangements in terms of democratic ideals and the creation of new market-oriented alternatives in their place. Overall, this development implied a relative state suspension of ambitions to guarantee equivalence within the higher education sector. Instead, students were increasingly seen as consumers, and diversification in terms of education quality was seen as a problem that could be targeted through competition. This displacement is particularly visible in the 2011-2014 system, in which increased stress was put on providing information to students to facilitate informed choices, informing 
the society at large of the accomplishments of higher education in general (accountability), and on including representatives of potential employers. This system was imposed on the HEIs, and traditional ideas on evaluation were displaced in favour of new components and technologies associated with new behavioural logics overall, an alien approach to the higher education sector at that time.

A second observation is that the change in evaluation models displays a successive advancement of comparability among HEIs. Comparability as a technology hence serves the purpose of establishing common standards and agreements and organise the HEI sector within an international and national market. Taken together, external demands have increasingly, and bit-by-bit, resulted in a displacement, where HEIs become more consumer oriented, a movement provoked by the evaluation exercises. In these processes, HEIs need to precisely spell out what it is the students need to learn and also the HEIs' degree of success in that respect (a declaration in advance of the quality of the service the student is "buying", similar to custom charters.) Rider et al. (2013) describe the profound impacts of universities' transformation from public and democratic institutions into marketised networks. These changes in the higher education system are similar to some of the changes observed in education more generally in Sweden and elsewhere (see, e.g. Ozga et al. 2011).

\section{Governing by Expectations}

When considering the expectations these different EQA systems may give rise to and the governing role they fill, we would like to emphasise the following:

After the 1993 reform, particularly from 1995 and onwards, there is a constant presence of some kind of national evaluation of higher education. This constant presence of external control also leads to the expectation for it to be there and to continue to be present. In turn, this is part of making higher education "auditable" according to Power (1996) or evaluable (see also Sahlin-Andersson 1995).

In the later periods, when the designs of the EQA systems first included sanctions, and then rewards, the HEIs also developed expectations of such sticks and carrots. The possibility of having the right to award degrees and certificates revoked makes the HEIs also expect such sanctions to be used (which they also are, albeit rarely). The consequences of expectations of such high-stakes evaluations are well known in educational research, particularly concerning widespread testing, where phenomena such as teach-to-the-test and window-dressing are developed (see, e.g. Linn 2000). Compliance is another consequence that easily makes educational considerations give way to juridical or managerial ones in order to avoid criticism (Lindgren et al. 2012; Solbrekke and Englund 2011).

From the implementation of the Bologna system, with Sweden's stress on a rationale based on objectives and results, particularly manifested in the design of the 2011-2014 EQA system, and its emphasis on student outcomes and attainment, the 
state expects the HEIs to deliver students who produce independent projects that are assessed as good enough. Consequences of this that we know include, for example, changes in resource allocation so that supervisors in courses for independent projects get more time for supervision and teachers in other courses get less time teaching (cf. Sørenssen and Mejlgaard 2014, pp. 26-27). Overall, such strategic responses to EQA raise critical questions. Do the designs of national EQA systems provoke the desire to improve/comply but take away/distort the performance? Hence, as pointed out by Hopmann (2008): “only those results which can be 'verified' according to the stakes given and do not meet expectations become problematic, and only those outcomes which meet the pre-defined criteria are considered a success" (p. 424).

As noted above, accreditation has been part of all EQA systems and has stayed much the same over the different periods - an important continuity to acknowledge despite certain and other simultaneous and ongoing processes of change. The different national agencies (the SNAHE and the SHEA) more or less had the same expectations for what the HEIs have to show in order to get permission to offer $\mathrm{PhD}$ programmes or to get the right to award degrees and certificates. This leads to stability in what the HEIs expect these accreditation processes to direct attention to, and that is of foremost attention to certain preconditions, such as share of teachers with a doctorate. One known consequence of this, however, is that HEIs try more intensely to increase their shares of faculty with a doctoral degree when they apply for the right to start a $\mathrm{PhD}$ programme. In general terms, the consequences of these reciprocal expectations are that the HEIs direct resources to live up to the different requirements in the evaluations.

The successive additions in the external panels of students, and of future employers in the 2011-2014 system, teach the HEIs, and develop expectations that parts of society outside the higher education sector, have legitimate interests in the scrutiny of higher education. Expectations are also raised about them having knowledge and competence enough to evaluate higher education. Extended influence by external stakeholders is by no means a Swedish higher education phenomenon, as Deem et al. (2007) and Magalhães et al. (2018) show in their studies of managerialism and higher education governing boards.

The state, on the other hand, expects the HEIs to accept all sorts of evaluators and also expects the HEIs to acknowledge that the expertise of the external panel is sufficient when it comes to higher education. A plausible consequence of these last two sets of expectations is a shift in the mindset of HEI managers and teachers/researchers to be more receptive to external demands on the direction of their work, that is, to make higher education and research better adapted to market needs. For example, this may mean increased efforts to produce more "useful" (applied) education and research. This is an example of what Dahler-Larsen (2012) labels constitutive effects, pointing to the potential of evaluations to influence not only behaviours but also our perceptions of the phenomenon/activity/programme that is being evaluated. 
The final kind of expectation we bring forward is based on the descriptions of the different designs of the national EQA systems. This expectation suggests that the shifts in designs themselves make the HEIs to expect changes. A consequence of that is that it has become necessary for the HEIs to always keep an eye on national policy developments and on what is required of them. They thus accept constant change, constant pressure, and constant control and must be on alert, thereby possibly avoiding the risk of drift (Mahoney and Thelen 2010). Depending on the more detailed shifting but also stable requirements in the different designs of the EQA systems, governing by expectations is both about what the HEIs expect the state (the national agencies) to do and what the state and national agencies (through decisions and policy) expect to happen at the HEIs.

\section{Building an Evaluation Machinery?}

Overall, we contend that the historical process of establishing national EQA systems in Sweden shows resemblance to what Dahler-Larsen (2012) describes in terms of evaluation machines. In this book, we use the evaluation machine analogy in our explorations of evaluation as a practice in governing the Swedish higher education case. As shown in this chapter, the EQA systems change constantly, leading us to use the notion of an "evaluation machinery" to denote the assemblage of elements that we have identified during the covered period. We equal an evaluation machinery with Dahler-Larsen's characterisation of evaluation machines as an ideal typical concept that draws attention to development within the audit society, where evaluation has become institutionalised and professionalised so that "arbitrariness and subjectivity" are eliminated (Dahler-Larsen 2012, p. 176). They are:

[m] andatory procedures for automated and detailed surveillance that give an overview of organizational activities by means of documentation and intense data concentration. (Dahler-Larsen 2012, p. 176)

Similar to evaluation machines, the Swedish national EQA machinery has become permanent and repetitive over time and functions as a producer of "streams of information" rather than occasional reports (Dahler-Larsen 2012, p. 177). It has become increasingly embedded in HEIs organisational procedures of verification and resource allocation; EQA is thus framed by ideas of "organizational responsibility" (Dahler-Larsen 2012, p. 177). As such EQA has also become a prospective rather than just a summative form of evaluation. Broad scales of activities related to EQA are "planned in advance so they can be intentionally linked to decision and implementation process" (Dahler-Larsen 2012, p. 177). EQA is hence increasingly reciprocal and has become a natural condition for HEIs. Over time, EQA has become based on "distinctive epistemological perspectives" and increasingly "relies on a number of tools or scripts such as definitions, indicators, handbooks, procedures, guidelines, etc., to support fairly standardized operationalisations" (Dahler-Larsen 2012, pp. 177-178). Finally, as an evaluation machinery, EQA cover "phenomena 
that have broad scope in time and space" (Dahler-Larsen 2012, p. 178). Higher education involves extensive and complex activities that are detailed "in a systematic and integrated way that permits comparison among areas of activities" (DahlerLarsen 2012, p. 178).

\section{Finally}

The notion of an evaluation machinery harbours a range of aspects that will be explored further in the upcoming chapters of the book. This notion draws attention to the role of documentation and specific forms of documentation in terms of selfevaluations that have become institutionalised over time. An evaluation machinery also require distinctive roles and knowledge for their functioning. They must be designed, engineered, and operated (Dahler-Larsen 2012). For example, what are the implications of increasing demands on external assessment panels and site visits in terms of forms of knowledge, expertise, experience, and social competence?

The issue of constitutive effects (Dahler-Larsen 2012) will also be pursued as an important theme in the book. In some of the following chapters, we will look more closely into this and explore some of the above described national EQA systems and processes, their consequences, and the way they influence and govern higher education.

In the next chapter, however, we turn to the wider international context and situate the Swedish example within Europe in order to understand development in higher education policy and EQA systems.

\section{References}

Ball, S. J., Maguire, M., \& Braun, A. (2012). How schools do policy: Policy enactments in secondary schools. London: Routledge.

Bauer, M., Askling, B., Gerard Marton, S., \& Marton, F. (1999). Transforming universities. Changing patterns of governance, structure and learning in Swedish higher education. London: Jessica Kingsley Publishers.

Clarke, J. (2015). Inspection: Governing at a distance. In S. Grek \& J. Lindgren (Eds.), Governing by inspection (pp. 11-26). London: Routledge.

Dahler-Larsen, P. (2012). Evaluation society. Stanford: Stanford University Press.

Dahler-Larsen, P. (2014). Constitutive effects of performance indicators. Getting beyond unintended consequences. Public Management Review, 16(7), 969-986.

Deem, R., Hillyard, S., \& Reed, M. (2007). Knowledge, higher education, and the new managerialism: The changing management of UK universities. Oxford: Oxford University Press.

Fourcade, M. (2010). The problem of embodiment in the sociology of knowledge: Afterword to the special issue on knowledge in practice. Qualitative Sociology, 33, 569-574.

Franke, S., \& Nitzler, R. (2008). Att kvalitetssäkra högre utbildning - en utvecklande resa från Umeå till Bologna [To quality assure education - A developmental journey from Umeå to Bologna]. Lund: Studentlitteratur. 
Franke-Wikberg, S. (1990). Utvärdering i och av gymnasieskolan. En principskiss [Evaluation in high school. A principle sketch] (Arbetsrapporter 86). Umeå: Umeå universitet, Pedagogiska institutionen.

Franke-Wikberg, S., \& Lundgren, U. P. (1980). Att värdera utbildning. Del 1 [To evaluate education. Part 1]. Stockholm: Wahlström \& Widstrand.

Franke-Wikberg, S., \& Lundgren, U. P. (Eds.). (1981). Att värdera utbildning. Del 2. En antologi om pedagogisk utvärdering [To evaluate education. Part 2. An anthology]. Stockholm: Wahlström \& Widstrand.

Government Bill 1992/1993:1. Universitet och högskolor - frihet för kvalitet [Universities and university colleges - Freedom for quality].

Government Bill 1999/2000:28. Studentinflytande och kvalitetsutveckling i högskolan [Student influence and quality development in higher education].

Government Bill 2009/2010:139. Fokus på kunskap - kvalitet $i$ den högre utbildningen [Focus on knowledge - Quality in higher education].

Government Bill 2009/2010:149. En akademi i tiden - ökad frihet för universitet och högskolor [A contemporary academy - Increased freedom for universities and university colleges].

Grek, S., \& Lindgren, J. (Eds.). (2015). Governing by inspection. London: Routledge.

Gröjer, A. (2004). Den utvärdera(n)de staten [The evalua(ing)ed state]. Doctoral dissertation. Stockholm: Stockholm University, Department of Political Science.

Herbst, M. (2009). Financing public universities. The case of performance funding. Dordrecht: Springer.

Hopmann, S. T. (2008). No child, no school, no state left behind: Schooling in the age of accountability. Journal of Curriculum Studies, 40(4), 417-456.

Hopmann, S. T., Brinek, G., \& Retzel, M. (2007). Pisa zufolge Pisa - Pisa according to Pisa. Wien: Lit-Verlag.

House, E. R. (1978). Assumptions underlying evaluation models. Educational Researcher, 7(3), 4-12.

Kettis, Å., \& Lindberg-Sand, A. (2013). Det svenska kvalitetssystemets kval - en dialog från olika utgångspunkter [The anguish of the Swedish quality system. A dialogue from different viewpoints]. Högre utbildning, 3(2), 139-149.

Leeuw, F. L., \& Furubo, J.-E. (2008). Evaluation systems. What are they and why study them? Evaluation, 14(2), 157-169.

Lindgren, J., Hult, A., Segerholm, C., \& Rönnberg, L. (2012). Mediating school inspection - Key dimensions and keywords in agency text production 2003-2010. Education Inquiry, 3(4), 569-590.

Linn, R. (2000). Assessment and accountability. Educational Researcher, 29(2), 4-16.

Magalhães, A., Veiga, A., \& Amaral, A. (2018). The changing role of external stakeholders: From imaginary friends to effective actors or non-interfering friends. Studies in Higher Education, 43(4), 737-753.

Mahoney, J., \& Thelen, K. (2010). A theory of gradual institutional change. In J. Mahoney \& K. Thelen (Eds.), Explaining institutional change. Ambiguity, agency and power (pp. 1-38). Cambridge: Cambridge University Press.

Ministry of Education. (2009). Uppdrag till Högskoleverket att föreslå ett nytt system för kvalitetsutvärdering av högskoleutbildning. Regeringsbeslut, U2009/1444/UH. [Commission to the SNAHE to propose a new system for quality evaluation of higher education]. Stockholm: The Government, Ministry of Education.

Neave, G. (1998). The evaluate state reconsidered. European Journal of Education, 33(3), 265-284.

Ozga, J., Dahler-Larsen, P., Segerholm, C., \& Simola, H. (Eds.). (2011). Fabrication quality in education: Data and governance in Europe. London: Routledge.

Pollitt, C. (1995). Justification by works or by faith? Evaluating the new public management. Evaluation, 1(2), 133-154.

Pollitt, C., \& Bouckaert, G. (2017). Public management reform (4th ed.). Oxford: Oxford University Press. 
Power, M. (1996). Making things auditable. Accounting, Organizations and Society, 21, 289-315. Power, M. (1997). The audit society. Rituals of verification. Oxford: Oxford University Press.

Rider, S., Hasselberg, Y., \& Waluszewski, A. (Eds.). (2013). Transformations in research, higher education and the academic market. The breakdown of scientific thought. Dordrecht: Springer.

Rosa, H. (2013). Social acceleration: A new theory of modernity. New York: Columbia University Press.

Sahlin-Andersson, K. (1995). Utvärderingars styrsignaler [The signals of governance in evaluations]. In S. Rombach \& K. Sahlin-Andersson (Eds.), Från sanningssökande till styrmedel. Moderna utvärderingar i offentlig sektor [From a search for truth to a governing instrument. Modern evaluations in public sectors] (pp. 71-92). Stockholm: Nerenius \& Santérus Förlag.

Segerholm, C. (2001). National Evaluations as governing instruments: How do they govern? Evaluation, 7(4), 427-438.

Segerholm, C. (2010). Utbildning, forskning, apor och bananer. Installationsföreläsning vid Mittuniversitetets årshögtid den 19 november 2010 [Education, research, monkeys and bananas. Inauguration speech at MidSweden's annual ceremony 19 November 2010]. Härnösand: Mittuniversitetet, the author.

Segerholm, C., \& Åström, E. (2007). Governance through institutionalized evaluation. Recentralization and influences at local levels in higher education in Sweden. Evaluation, 13(1), 48-67.

Segerholm, C., Rönnberg, L., Lindgren, J., Hult, A., \& Olofsson, A. (2014). Changing evaluation frameworks - Changing expectations? The case of Swedish higher education. Paper presented at the European Conference for Educational Research, Porto, 2-5 September, 2014.

SHEA. (2013). Reflektioner kring det nuvarande utvärderingssystemet. Erfarenheter 2011-september 2013 [Reflections over the present evaluation system. Experiences 2011-September 2013]. Stockholm: SHEA.

SNAHE. (1998). Fortsatt granskning och bedömning av kvalitetsarbetet vid universitet och högskolor. Utgångspunkter samt angrepps- och tillvägagångssätt för Högskoleverkets bedömningsarbete [Continued evaluation and assessment of quality work at universities and university colleges. Starting points, approach and methods for the SNAHE's evaluation work] (Högskoleverkets rapportserie 1998:21). Stockholm: SNAHE.

SNAHE. (2001). National review of subjects and programmes in Sweden (Högskoleverkets rapportserie 2001:11R). Stockholm: SNAHE.

SNAHE. (2003). Nationella ämnes- och programutvärderingar. Anvisningar och underlag för självvärdering. Reviderad maj 2003 [National evaluations of academic subjects and programmes. Instructions and template for self-evaluation. Revised May 2003]. Stockholm: SNAHE.

SNAHE. (2007). Nationellt utvärderingssystem för perioden 2007-2012 [National evaluation system for the 2007-2012 period] (Högskoleverkets rapportserie 2007:59R). Stockholm: SNAHE.

SNAHE. (2010). Högskoleverkets system för kvalitetsutvärdering 2011-2014 [The SNAHE's system for quality evaluation 2011-2014] (Högskoleverkets rapportserie 2010:22R). Stockholm: SNAHE.

SNAHE. (2012). Högskoleverkets system för kvalitetsutvärderingar 2011-2014. Examina på grundnivå och avancerad nivå [The SNAHE's system for quality evaluations 2011-2014. Degrees at bachelor and master levels] (Högskoleverkets rapportserie 2012:4R). Stockholm: SNAHE.

Solbrekke, T. D., \& Englund, T. (2011). Bringing professional responsibility back in. Studies in Higher Education, 36(7), 847-861.

Sørenssen, M. P., \& Mejlgaard, N. (2014). Autonomi och kvalitet - ett uppföljningsprojekt om implementering och effekter av två högskolereformer i Sverige. Delredovisning 2. 2013/14 $R F R 22$ [Autonomy and quality. A follow-up project about implementation and effects of two reforms in higher education in Sweden. Report 2]. Stockholm: Riksdagstryckeriet.

Thelen, K. (2000). Timing and temporality in the analysis of institutional evolution and change. Studies in American Political Development, 14, 101-108. 
Thelen, K. (2003). How institutions evolve: Insights from comparative historical analysis. In J. Mahoney \& D. Rueschemeyer (Eds.), Comparative historical analysis in social sciences (pp. 208-241). Cambridge: Cambridge University Press.

Wahlén, S. (2012). Från granskning och bedömning av kvalitetsarbete till utvärdering av resultat [From review and assessment of quality work to evaluation of results]. In SNAHE (Ed.), En högskolevärld i förändring. Högskoleverket 1995-2012 [A changing landscape of higher education] (pp. 27-35). Stockholm: SNAHE.

Open Access This chapter is licensed under the terms of the Creative Commons Attribution 4.0 International License (http://creativecommons.org/licenses/by/4.0/), which permits use, sharing, adaptation, distribution and reproduction in any medium or format, as long as you give appropriate credit to the original author(s) and the source, provide a link to the Creative Commons license and indicate if changes were made.

The images or other third party material in this chapter are included in the chapter's Creative Commons license, unless indicated otherwise in a credit line to the material. If material is not included in the chapter's Creative Commons license and your intended use is not permitted by statutory regulation or exceeds the permitted use, you will need to obtain permission directly from the copyright holder.

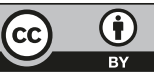




\title{
Europe in Sweden
}

\author{
Christina Segerholm and Agneta Hult
}

\begin{abstract}
The increased importance given to European policy concerning evaluation and quality assurance in higher education in the Swedish national policy context is explored in this chapter. The description rests on interviews with what here is labelled policy brokers and on the material from the European Association for Quality Assurance in Higher Education (ENQA), as well as government bills, parliamentary minutes, national agency reports, and university teachers' union journals. The results show that ENQA membership requirements played a significant role in the Swedish policy debate on the design of the 2016 national evaluation and quality assurance system. Dissemination channels between Europe and Sweden are populated by individuals with similar functions and positions, e.g. that ministers often meet ministers. Within Sweden, European policy is disseminated by and through individuals who move between different positions within the ministry of education, national agencies, and higher education institutions. Different organisations also communicate with each other within Sweden, ensuring European policies reaching into higher education institutions. Such European governing attempts are carried out in activities like networks, conferences, papers, guidelines, and by using different forms of knowledge, both inscribed, embodied, and enacted.
\end{abstract}

\section{Introduction}

In the previous chapter, we analysed the development of national evaluation and quality assurance systems mainly as a national issue. However, we also noted that Sweden's engagement in the Bologna Process influenced the evaluation and quality assurance systems, for example, by placing an increased stress on expected learning outcomes. The European policy agenda also gained power in the debate following the membership status of the Swedish National Agency for Higher Education (SNAHE) in the European Association for Quality Assurance in Higher Education

C. Segerholm $(\bowtie) \cdot$ A. Hult

Department of Education, Umeå University, Umeå, Sweden

e-mail: christina.segerholm@umu.se; agneta.hult@umu.se

(C) The Author(s) 2019

C. Segerholm et al. (eds.), The Governing-Evaluation-Knowledge Nexus,

Evaluating Education: Normative Systems and Institutional Practices,

https://doi.org/10.1007/978-3-030-21143-1_3 
(ENQA) following the 2011-2014 national system. The amplified importance of European evaluation and quality assurance policy for Sweden is portrayed in this chapter. We will deepen the study of European influence and governing potential and explore the European arena and its relation to Swedish higher education policy concerning evaluation and quality assurance (EQA). ${ }^{1}$

Knowledge and ideas about evaluation and quality assurance may exist in national/state agencies to a lesser or larger degree. As shown in the previous chapter, Sweden has used a handful of national evaluation and quality assurance systems for higher education during the last decades, and, through these processes, certain knowledge about EQA and governing has been acquired (e.g. Franke and Nitzler 2008; Kettis and Lindberg-Sand 2013). Such knowledge has progressively been brought together and circulated in transnational spaces (e.g. the ENQA 2010). Through these transnational spaces, circulation or dissemination of policies and knowledge about EQA among national/state agencies and contexts also takes place.

Since the signing of the Bologna agreement for European higher education, a number of initiatives, programmes, and organisations have been launched. These efforts can be summarised by the concept of "Europeanisation" (e.g. Grek and Lawn 2012; Jacobsson 2010a). An explicit political purpose is to safeguard Europe's position on the global market. Education is believed to promote this, and it is argued that student, teacher, and researcher mobility would facilitate this ambition (Standards and Guidelines for Quality Assurance in the European Higher Education Area, ESG, 2015, p. 6). Coordination of different national education systems is one way to sustain this mobility ambition. As higher education is not regulated by European laws and regulations, processes of coordination must rely on "soft" governing (Lawn 2006) through means like the open method of coordination, which is based on:

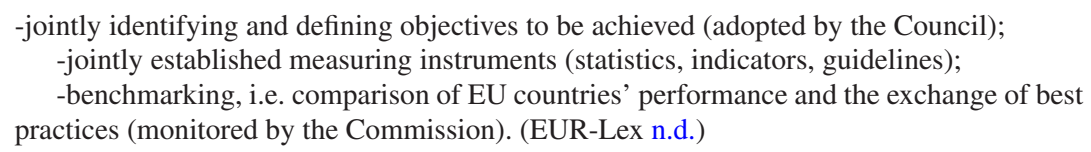

It is also said that to support and increase mobility, national higher education systems have to be trusted to deliver high-quality education, and it is claimed that quality assurance (QA) is the means to achieve this (ESG 2015, p. 6). In the last decades, a number of reforms have been implemented, and multiple QA activities have been performed (Maassen and Stensaker 2011).

One of these initiatives and from 1999 specifically directed at ensuring "more comparable, compatible and coherent systems of higher education in Europe" is the European Higher Education Area, (EHEA n.d.-a). A central purpose of the Bologna Process, and hence the EHEA, is to "encourage European cooperation in quality assurance of higher education with a view to developing comparable criteria and methodologies" (EHEA n.d.-b). For this reason, the European ministers of education

\footnotetext{
${ }^{1}$ The chapter is based on two conference papers that have been revised and updated: Segerholm and Hult $(2015,2017)$.
} 
agreed to support the Standards and Guidelines for Quality Assurance in the Higher Education Area (ESG) in 2005, which was drafted by the European Association for Quality Assurance in Higher Education, ENQA (ENQA 2009; Thune 2010), and revised in 2015 (Standards and Guidelines for Quality Assurance in the European Higher Education Area (ESG) 2015).

In spring 2019, 50 QA agencies in 28 countries were full members of the ENQA, which means that they met QA policies and practices set up by the organisation. Since all EQA activities are part of governing work (Ozga et al. 2010), our argument is that ENQA membership (or striving for ENQA membership) can be significant when attempting to understand how certain governing policies and practices are brokered and translated into the European context and beyond.

In this chapter, we investigate the significance of membership in the ENQA and its relation to the governing of higher education. Here, Sweden is an interesting example in that its national agency for higher education was a full member of the ENQA, but this status was questioned in 2012 (ENQA 2012), and membership was revoked in February 2014 (ENQA 2014a). This state of affairs fuelled an already existing debate about the shortcomings of the national EQA system in existence from 2011 to 2014 and was linked to political discussions about the design of a new EQA system, which we analyse more thoroughly in the chapter "Hayek and the Red Tape: The Politics of Evaluation and Quality Assurance Reform - From Shortcut Governing to Policy Rerouting". The specific focus of this chapter is the relation between the ENQA's policy and Sweden's policies on EQA and the channels by which European policy enters Sweden. We recognise that policy dissemination and circulation (i.e. brokering) may occur in bi- or multidirectional processes, not just from one part or level to another. The special situation of the Swedish agency's nonENQA membership did however produce a particular national policy context in which European and ENQA policy became very influential. Our aim is, therefore, to explore the influence of the ENQA policy on the Swedish national EQA policy in higher education and how the ENQA policy enters the Swedish policy context and forms part of the governing of Swedish higher education during a period of nonmembership of the Swedish agency.

The questions we pursue are:

- How is the ENQA's policy visible in the Swedish national policy process?

- Through what channels was ENQA policy disseminated, and what policy was perceived as important in Swedish national policymaking?

- How does ENQA policy relate to the governing of higher education in Sweden?

\section{Theoretical Notes, Methods, and Material}

In this book, we have emphasised governing as a verb, i.e. to focus on activities and the work that is "done", be it by talking to people, writing texts, arranging and participating in meetings and workshops, and/or by decision-making bodies. In this 
context and as we outlined in the chapter "Governing by Evaluation: Setting the Scene", we conceptualise "governing" as a verb so as to underline that attempts to develop, disseminate, and implement policy require activities and work, as do attempts to develop and disseminate practice.

In an effort to promote stronger and more unified education policies throughout Europe, different activities are carried out to influence member countries (and perhaps others) to accept and also develop similar policies and practices. As we will show in this chapter, different methods are used to increase the governing power of European policies. Ways of disseminating policy and practice that can influence (govern) beyond the central European sphere have been described and analysed by Jacobsson (2010a, b) through the concepts of "regulative, inquisitive, and meditative" governing activities. "Regulative" refers to activities like rule-making and mandatory obligations where penalties can be invoked if the rules are broken. "Inquisitive" activities require organisations to be open to examination, inquiry, scrutiny, and/or different sorts of assessments. Finally, "meditative" activities, which form the foundation of the other two, are in themselves a separate type of activity that includes verbal and written interaction, sometimes in spaces particularly aimed for such activities (e.g. workshops, meetings, conferences) where the exchange of experiences and probing of common issues are central (Jacobsson 2010a, pp. 4-6.) This conceptual frame also points to different ways that policy may be brokered and disseminated.

The importance of national and local contexts in these processes (Ozga and Jones 2006; Steiner-Khamsi 2004; Sassen 2007) is also noted. European education policy has to make national sense and be translated and interpreted to fit specific national contexts so as to influence already existing policy and practice. In European governing and policy work, nation-states are more or less actively involved. Involvement requires balancing internal national interests with national and international requirements. To come to international agreements and consensus on ENQA membership requirements, active work is needed by nation-states, sometimes with actors holding oppositional views (see Sassen 2007) where struggles and conflicts occur over time and have to be addressed. Therefore, national and local contexts affect when, how, and what policies travel, how they are disseminated and translated, and how governing influenced by international (European) policies is possible. In the Swedish case, several actors take part in discussing higher education policy and the EQA system(s), and the state (government and agencies) has interacted with these actors in different ways during the periods we studied (see also the chapter "Hayek and the Red Tape: The Politics of Evaluation and Quality Assurance Reform - From Shortcut Governing to Policy Rerouting"; Lindgren and Rönnberg 2015). There are also actors that function as links, or brokers, between Sweden and the European/global space. These are what Lawn and Lingard (2002) call "policy elites", composed of actors like ministers, high-ranking civil servants, and experts in different policy fields. They meet in different organisations to discuss mutual policy issues, exchange experiences, and decide on common policies and actions.

This chapter is based on interviews with ten such national policy brokers carried out mainly in spring 2015. We also collected and analysed a variety of documents 
from the ENQA and other European organisations, from Swedish government bills and parliamentary minutes, documents, etc., and documents from the two national agencies responsible for supervising higher education in Sweden. In addition, we also analysed material from the university teacher union's journal and daily national press (Svenska Dagbladet).

Next, a description of the ENQA is presented based on official ENQA documents. We then scrutinise the ENQA influence through its membership requirements and relate them to the Swedish EQA contexts, showing that European governing attempts through QA policies enter the national context of Swedish QA. In this account, we also insert examples of the internal national debate in Sweden to exemplify the influence of the ENQA on the national policy space. Next, we investigate how these Europeanising processes are experienced and handled by what we here call national policy brokers and through which channels European policies enter Sweden. We then describe these intranational dissemination channels. The chapter ends with a discussion of our findings, which we discuss in relation to the importance of governing by comparison, in the dissemination of EQA and governing policy.

\section{The ENQA}

The history of the ENQA goes back to the beginning of the 1990s when "national quality assurance agencies had started to arrange unofficial meetings in the early and mid-1990s in order to exchange information and, quite practically, to get to know each other" (Ala-Vähälä and Saarinen 2009, p. 90; see also Kauko 2012). This was a process in which Sweden was actively involved, and the country also became one of the early members in 2000. The European Commission had a general interest in supporting QA processes and took a particular interest in such activities in higher education, leading to a number of pilot projects (Enders and Westerheijden 2014; Kristensson 2010). After the finalisation of these projects, ministers for higher education in EU and EFTA/EEA countries, representatives for QA agencies, and associations for higher education met in Brussels for a conference where the ENQA network was launched (Thune 2010, p. 9). In 2011, it was transformed into the organisation European Association for Quality Assurance in Higher Education and kept its acronym ENQA. The stated mission of the organisation is to contribute to quality enhancement of European higher education, to develop QA processes, represent its members internationally, influence policymaking at the European level, promote cooperation among QA agencies, and "foster the European dimension of quality assurance of higher education" (ENQA statutes 2015, article 3). This is to be achieved by providing services and expertise, opportunities for networking, and coordinating external reviews of QA agencies. The ENQA also engages in the Bologna Process in projects, publication of reports and policy papers, and in cooperation with stakeholder organisations in higher education in Europe and worldwide (ENQA statutes 2015, article 4). European EQA policy travel through these 
activities, and are some of the means in operation to influence European countries. Activities like these are what Jacobsson (2010a, b) calls meditative processes. Another avenue for the ENQA to influence higher education through quality assurance policy and practice is the importance put on membership requirements.

\section{The ENQA's Membership Requirements and Sweden}

To become a member and have access to the ENQA's activities, member organisations must meet certain conditions (ENQA statutes 2015, article 5-8). There are two types of involvement: membership and affiliation:

Membership is open to European quality assurance bodies in the field of higher education that are conducting quality assurance activities as understood in the Standards and Guidelines for Quality Assurance in the European Higher Education Area (ESG) and act in compliance with the membership criteria. (ENQA statutes 2015, article 5)

The ESG is divided in three parts. The first part concerns quality standards and criteria for higher education institutions. The second part "basically required QA agencies to check how higher education institutions had implemented Part I, and in Part III required the QA agencies to be regularly reviewed themselves" (Enders and Westerheijden 2014, p. 173). Affiliation concerns QA bodies that cannot or do not wish to become members. Nonetheless, they still must agree to abide by the statutes of the ENQA, which in Jacobsson's (2010a, b) terminology would be considered governing by regulative activities.

ENQA regulations require member agencies to undergo an external review at least once every 5 years, which is an example of an inquisitive activity (Jacobsson 2010a, b). The SNAHE had been a member of the ENQA since 2000 and was also confirmed as a full member in 2005-2006 (SNAHE 2006). However, the EQA system established in 2011 was reviewed by an ENQA review panel in 2012 and assessed to be "fundamentally at odds with the ESG" (SNAHE 2012, p. 23). The main areas where the Swedish system deviated from ENQA principles were in not evaluating higher education institutions' internal QA systems and in not giving recommendations for improvement. Also, according to the review panel, the Swedish agency responsible for QA could not be considered independent (ENQA $2009,3.6)$ "due to the extent to which their procedures and methods, as well as overall aims and objectives have been dictated by government" (SNAHE 2012, p. 23). This news was highlighted in the University World News, which described the distress it caused in the higher education sector (Mycklebust 2012). Later the same year, the ENQA board decided that the Swedish agency was a "full member under review", and it was to be reviewed again in 2014 (ENQA 2012). However, in 2014, the criticised national EQA system was about to be phased out, and a new system was under development, and the application for full membership was to be postponed until the new national EQA system was in place. Since February 2014, the Swedish agency is not a member of the ENQA (ENQA 2014a). 
The national EQA system was critiqued, debated, and analysed by scholars across disciplines throughout the period of its existence of 2011-2014 (see, e.g. Adamson 2013; Ericsson 2014; Haikola 2013; Kettis and Lindberg-Sand 2013; Lundmark and Sjölund 2012; Sedigh 2013). It was challenged by the Association of Swedish Higher Education Institutions (ASHEI, SUHF Sveriges universitetsoch högskoleförbund $)^{2}$ and debated within the Swedish Association of University Teachers and Researchers (SAUTR, Sveriges Universitetslärares Förbund SULF) and by the Swedish National Union of Students (SNUS, Sveriges Förenade Studentkårer $S F S$ ). In these debates, the lost ENQA membership and suspension of the Swedish national agency (Swedish Higher Education Authority, SHEA) were used as arguments to reform the national EQA system. In an interview, one teacher union representative said the suspension was "embarrassing" (Dagens Arena 2014). The chairman of the national student union wrote that "Sweden cannot apply for new membership for another two years, which is a big blow to the international reputation of the Swedish education system" (Arroy 2014). The issue of ENQA membership was also brought up by the political opposition in parliament, and the Minister of Education from the Liberal Party framed his response this way:

\begin{abstract}
Mister President! Jabar Amin [MP from the Green Party] has asked me what I intend to do to guarantee that Sweden will have a quality assurance system that is good enough and may install confidence for Sweden in this respect. Ibrahim Baylan [MP from the Social Democratic Party, our clarification] has asked me what I have done to avoid a termination of the membership [in ENQA] and what measures I plan to take in order to reinstall confidence for the Swedish higher education system. (...) The SHEA is responsible for a development work where they, along with representatives for the higher education institutions, the students, and labour market undertake certain adjustments of the quality assessment system. With these adjustments, the SHEA should be able to fulfil the ENQA's requirements for full membership. (Parliament Minutes 2013/2014:81, p. 3)
\end{abstract}

In 2013, the SHEA was commissioned to develop a revised national EQA system, which was planned to be presented publicly in spring 2014 but was cancelled just prior to launch (SHEA Central staff). The ASHEI sent a proposal in April 2014 to the Ministry of Education in which they suggested a new EQA system for higher education where the responsibility for performing QA and evaluations would be transferred from the national agency to the higher education institutions themselves (ASHEI 2014). This was rapidly followed by an article in one of the national newspapers, signed by all vice chancellors and the chairman of the national student union. In the article, an overview of the proposed new system was presented (Svenska Dagbladet 2014). It was pointed out that the suggested system would be fully compatible with the ENQA membership requirements. An immediate response from the government was to assign a special investigator to develop and propose a

\footnotetext{
${ }^{2}$ This is an organisation in which the vice chancellors of all higher education institutions form a strong interest group that increasingly put pressure on the government and try to develop common advice for how to act in relation to the new policy landscape that opened up by recent reforms (ASHEI n.d.). Even though the ASHEI represents the name of the entire higher education sector, the organisation does not necessary represent teacher and researcher interests and opinions.
} 
new national EQA system (Government Office 2014). The instructions said that "principles for quality assurance at the European level shall be taken into account" (Government Office 2014, p. 1).

\section{European Policy Enters a Proposed National EQA System}

In April 2014, the government appointed the soon-to-be university chancellor and Director General of the SHEA as the special investigator. The instructions concerning European-level principles stated that the new system should include the higher education institutions' (HEI) own work on QA and that the system should be quality driven and give the HEIs recommendations to improve education (Government Office 2014, p. 1).

As will be shown in the chapter "Hayek and the Red Tape: The Politics of Evaluation and Quality Assurance Reform - From Shortcut Governing to Policy Rerouting", the preparation with the special investigator's proposal involved a large number of stakeholders (see also the chapter "Enacting a National Reform Interval in Times of Uncertainty: Evaluation Gluttony Among the Willing"). At this time, new ENQA standards and guidelines were proposed but not decided on, although a preliminary version from September 2014 had been presented (ENQA 2014b) and was taken into account. The special investigator presented her suggestion to the government in late 2014. Afterwards, in March 2015, the government crafted a memorandum through which their ideas concerning a new national EQA system was circulated to the HEIs and other stakeholder organisations for comments (Ministry of Education 2015). The memorandum was said to outline an overall framework, and the SHEA was then responsible for developing and implementing the details and design of this new system. In this work, the agency was to pay attention to the government's considerations as well as to national laws and ordinances. The agency was also to adhere to the international principles for QA that were developed within the framework of the Bologna Process (Ministry of Education 2015).

Throughout the memorandum, the importance of developing the system in accordance with European and international QA principles was put forward, and the Ministry clearly referred to the ESG and to the organisations involved in and responsible for them (Ministry of Education 2015, pp. 11-12). An overall emphasis was also put on an EQA system that should help improve higher education and not only control for results.

In the following political process, the European policy on EQA for higher education continued to be prominent in the Swedish context. The government collected comments from the HEIs and other stakeholders during 2015 and produced a government petition (2015/2016:76) to the parliament in December 2015 in which it once again was stressed that a new national EQA system for higher education should take into account "those principles that have been put forward within the frames of the Bologna process" (Government Petition 2015/2016:76, p. 7). This was also endorsed by many of the stakeholders in their comments on the government memo- 
randum (Ibid.). To provide background for the position taken, the government petition described the political aims with the ESG and the ENQA and what had happened to the Swedish agency's membership in that organisation (Ibid.).

The Parliament Standing Committee on Education handled the issue further, and in its discussions of the government petition, it also brought forward the European principles for QA (Parliament Standing Committee on Education 2016, pp. 17-18). The committee's proposal to the parliament also accounted for the Swedish agency's membership status in ENQA and described the process that led to the termination of ENQA membership (Parliament Standing Committee on Education 2016, p.14). In March 2016, the parliament finally decided on a new national EQA system in line with the framework set out by the government (Parliament Decision 2015/2016:155).

While they were waiting for a definitive parliamentary decision to launch a new national EQA system, the SHEA began developing and testing some of its planned components, some of which were already suggested in the 2015 Ministry memorandum (for instance, in the format of pilot evaluations of $\mathrm{PhD}$ programmes). This work continued in 2016 and 2017 when the SHEA performed pilots of the main parts of the new EQA system (SHEA 2016a, 2017, 2018). The new and existing system and its design and implementation process are explored in more detail in the chapters "Re-launching National Evaluation and Quality Assurance: Expectations and Preparations" and "Re-launching National Evaluation and Quality Assurance: Governing by Piloting". In the context of this chapter, however, we want to highlight that the SHEA repeatedly and consistently underlined the importance of the ESG in all its activities related to developing the design of and pilots of the new system. As an illustration, this was evident in the SHEA Guidelines for HEIs' selfevaluations and external assessor panels in the pilot evaluation of institutional reviews that should assess the HEIs' internal QA systems (SHEA 2016b). In those guidelines, particular standards and the ESG as a whole were referenced in detail. Occasionally, there were translations almost to the letter, as is the case concerning the ESG 1.2 and 1.3 (ESG 2015, pp. 11-12) and their equivalents, Aspects 3.1 and 3.2 in the SHEA Guidelines (SHEA 2016b, pp. 22-25).

As we have shown so far, the national political context matters (cf. Ozga and Jones 2006) when it comes to how receptive Sweden has been in relation to European EQA policy. When the Swedish agency's ENQA membership status was finally revoked in 2014, concerns were raised from many stakeholders pointing to the lack of international legitimacy of the Swedish EQA system. One way of coming to terms with these national concerns was to develop a new national system more in line with the ESG. Our data recurrently display how policymakers and stakeholders in the higher education sector were preoccupied with regaining international legitimacy through the adoption of the ESG and reinstated ENQA membership. This is evidenced by continual references to and arguments for the importance of adherence to European policies in matters that were voiced in the national political debate. This is what Sassen (2007) refers to as the important policy work necessary for national agreement on issues where oppositional views exist. Such work is also needed to facilitate policy translation work to fit a specific national context (Ozga 
and Jones 2006; Steiner-Khamsi 2004; Shattock 2014). We will get back to these issues in the chapter "Re-launching National Evaluation and Quality Assurance: Expectations and Preparations" where the design work of the 2016 system is further scrutinised.

We have also shown that the European EQA policy influenced Swedish national EQA policy, later resulting in the new national EQA system of 2016. Some of the explanations for this state of affairs were also given by what we call the policy brokers or elites (c.f. Lawn and Lingard 2002). Next, we turn to these policy brokers and their experiences of how and what policies travel with an emphasis on the routes or channels policy takes in entering and circulating in Sweden, what we here call dissemination. We use the concept of dissemination to denote an intentional process of negotiating and spreading policy to different (European) countries and to different actors within countries. We also conceive dissemination to be akin to circulation, meaning that some ideas are spread widely and become authoritative by such a process (Sahlin and Wedlin 2008). The idea of channels developed from empirical data where some organisational relations turned out to be rather prominent. This inspired us to view dissemination of EQA policies through these channels.

\section{EQA Policy Dissemination}

In the following section, we first describe the European and other organisations' links to Sweden before moving on to describe the internal Swedish dissemination channels. The types of dissemination activities and the primary content of those activities are also reported.

\section{European and Other Dissemination Channels}

Overall, the channels through which European EQA policies for higher education travel, are disseminated, and enter Sweden are generally bi- or multidirectional. But it is quite clear that the predicament with the questioned, and later revoked, ENQA membership made Swedish policy actors and brokers more receptive and sensitive to European and ENQA influences, giving the policy flow a more unidirectional character during this period.

The ten policy brokers we interviewed worked in the Ministry of Education, the SHEA, the ASHEI, teachers and student unions, and a lobby organisation. Many of these persons had experiences from different parts of the higher education sector, including political and/or administrative offices and/or high-level leadership positions in HEIs.

The policy brokers talked about a number of European, global, and Nordic organisations as particularly important for them and the organisations they represented in relation to EQA (see Fig. 1). Not surprisingly, informants at the 


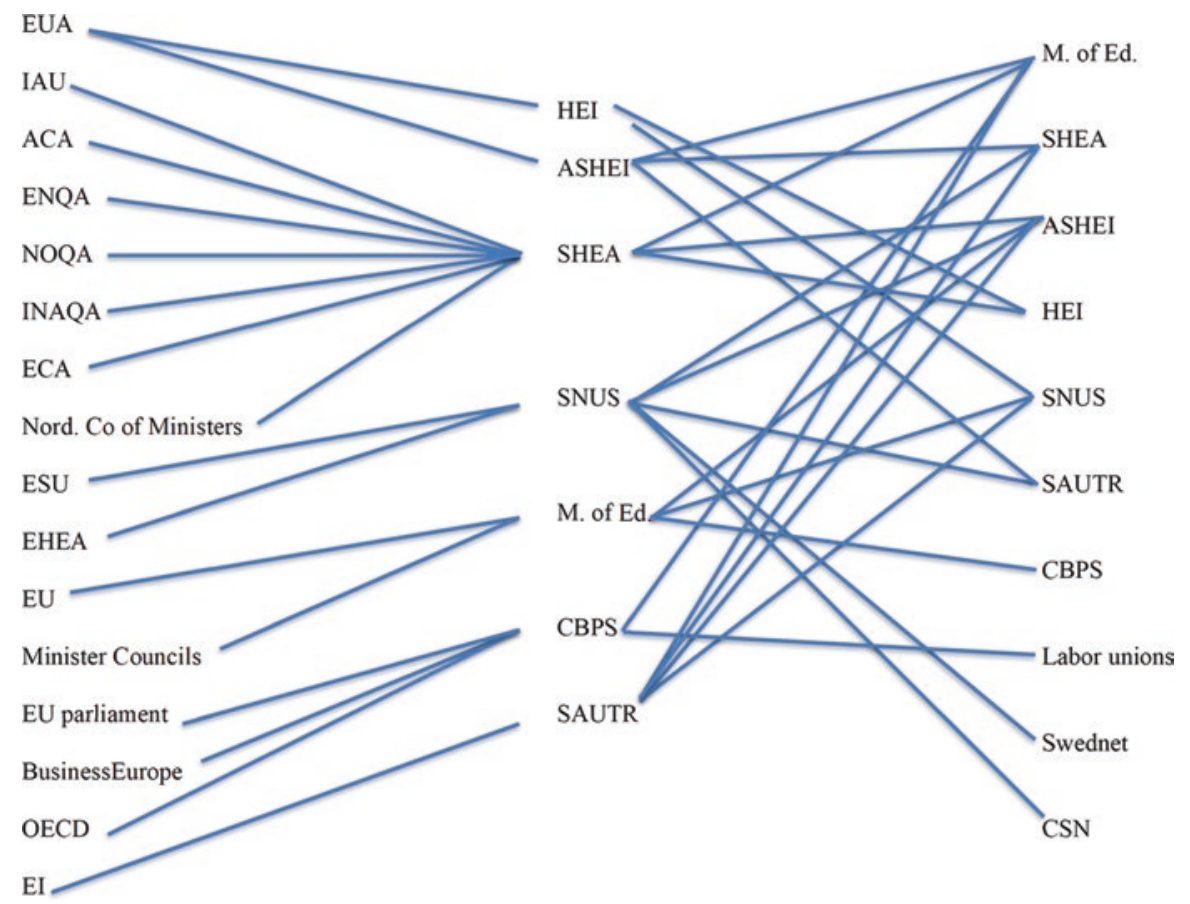

Fig. 1 From left to right: European/international to Swedish dissemination channels; internal Swedish dissemination channels

SHEA were involved with the highest number of international organisations, since the SHEA as a national agency is responsible for the supervision of higher education and is expected to engage in EQA policy and practice and promote such activities. Important organisations for these policy brokers were the ENQA (emphasising the ESG), the European Consortium for Accreditation in Higher Education (ECA), and the European Quality Assurance Forum (EQAF). The International Association of Universities (IAU) and the International Network for Quality Assurance Agencies in Higher Education (INQAAHE) were put forward. As non-European organisations, the Nordic Quality Assurance Network in Higher Education (NOQA) and the Nordic Council of Ministers were also stressed.

Another central policy actor when it comes to higher education policy and EQA is, of course, the government and its Ministry of Education. In our interviews, Ministry participants mentioned the European Commission and the Council of Ministers and the Nordic Council of Ministers as important venues for Sweden concerning policy information and discussions about EQA policy in higher education. Again, this is hardly surprising, as these channels are the formal ones one would expect European policies to take.

Ever since the so-called autonomy reform in Sweden was decided upon in 2010, leaving space for the HEIs to decide on internal organisation and positions (see 
the chapter "National Evaluation Systems"), the ASHEI has increasingly worked to establish a common policy platform for the Swedish HEIs and has strengthened its influence on national policy. This actor organises the vice chancellors of higher education and has a task force solely working with issues of EQA. The ASHEI participants claimed that their most important international contacts in this respect were with the European University Association (EUA), and, as the ASHEI in a way represents the HEIs, respondents indicated that the EUA is also an essential contact for the HEIs.

Another policy actor is the Centre for Business and Policy Studies (CBPS, Studieförbundet Näringsliv och Samhälle SNS), which organises private companies, research organisations, public enterprises, and national agencies. It engages in policy activities, research, lobbying, and policy advocacy concerning all areas of societal welfare. Our informant at this organisation said that the main policy contacts for them, in relation to EQA and higher education policy outside Sweden, are the European Parliament, BusinessEurope, ${ }^{3}$ and the Organisation for Economic Co-operation and Development (OECD).

Two policy brokers in our sample representing teachers, researchers, and students in higher education were from the SAUTR and the SNUS. The informant at the first organisation brought forward the Education International ${ }^{4}$ (EI) as an important link for them in relation to EQA. The second recognised the European Students' Union (ESU) as an organisation that they interact a lot with. The EHEA was also mentioned as a more general resource for their policy work.

\section{What Policy Is Important for Sweden?}

We also found it interesting to take a closer look at which issues, according to the policy brokers, some of the European actors disseminate in Sweden. Not surprisingly, the ENQA and its interest in QA models and systems were most often mentioned by the policy brokers. They indicated that the ENQA offers a possibility to review QA models in other countries and compare them to the Swedish model, thereby making it possible to assess the Swedish model and to monitor the changes in EQA policy. The policy brokers said that the ENQA paves the way for international agreements like the ESG and is important for mutual recognition of different kinds of higher education systems in European countries. This is significant for future student exchanges among European countries, they explained. Additionally, the ENQA provides opportunities to reconsider boundaries between politics and academics

\footnotetext{
3 "BusinessEurope is the leading advocate for growth and competitiveness at European level, standing up for companies across the continent and campaigning on the issues that most influence their performance" (BusinessEurope n.d.).

${ }^{4} \mathrm{EI}$ is a global umbrella organisation for labour union organisations for teachers and researchers in preschool up to higher education.
} 
and can help politicians understand that they have to work with the academic community and not against it, as one informant put it.

Another often mentioned association was the EUA, and the topic that was most interesting for Swedish policy was different aspects of autonomy for the HEIs in relation to central state power and authority. EUA conferences and study visits are argued to give insight opportunities to compare Swedish HEIs with other European HEIs. This comparison has, according to the policy brokers, shown that the autonomy for Swedish institutions is more restricted compared to other European countries. The HEIs in other countries are claimed to be more trusted than the Swedish ones, and in these countries, the HEIs also take a greater responsibility for their internal quality. One of the policy brokers said:

The great boundary line, I think, is between the systems that trust the universities and the ones that don't trust the universities. Sweden has had a system where they don't trust the universities; we have had that for many, many years in different shapes. I hope for a change towards a system that trusts the universities. If you make this distinction, the result will be two completely different models. (PB4)

Different European organisations also nourish conflicting interests in Sweden. The ESU is argued to be important in their resistance to the OECD's instrumental views of higher education - that education primarily should serve the labour market-according to the SNUS informant. Then again, the representative for the CBPS emphasised BusinessEurope in their mission of emphasising the importance of education and training in relation to the need for the labour market and public welfare.

Taken together, dissemination of EQA policy runs through channels with the help of a variety of activities that are designed to bring people and organisations together. In our interviews, such activities were described as conferences, workshops, annual membership meetings, formal meetings, study visits to other countries, hearings, and dialogues. Several of these are face-to-face activities and were talked about with enthusiasm by the informants. They resemble what Jacobsson (2010a, b) calls meditative activities and very much rely on social skills to be convincing enough to inspire travel and translation into different national and local contexts.

\section{Internal Swedish Dissemination Channels}

Within Sweden, the picture is more complex, indicating interesting connections between different organisations and actors that might aid further dissemination (see Fig. 1). Starting with the Ministry of Education, the informants there said that they "naturally" interact with the SHEA. Other connections of importance are the ASHEI, the SAUTR, the SNUS, and the CBPS. One informant also said that particular private companies may be of interest.

The SHEA informants equally "naturally" mentioned the Ministry of Education, the HEIs, the SAUTR, and the ASHEI as central to their work with evaluation and 
EQA policy, as these are regarded as the primary stakeholders. The ASHEI, in turn, had a mutual interest in the SHEA, the Ministry of Education, the HEIs, and the SNUS. The informant at the SAUTR stressed the relation to the SNUS, and of course to the HEIs, but also mentioned the Ministry of Education and the SHEA. Likewise, the SNUS informant talked about the link to the SAUTR but also mentioned other unions that organise HEI teachers, researchers, and other professionals with higher education degree requirements, like the Swedish Confederation of Professional Employees (Tjänstemännens centralorganisation, $T C O)$. This informant also said that $\mathrm{Swednet}^{5}$ is important for their policy work.

The informant from the CBPS said that as they are an organisation based on membership organisations, their important contacts are with their members and also with the Ministry of Education when it comes to EQA issues in education in a Swedish policy context.

When we conducted the interviews with this selection of policy brokers, it also became evident that they, as individuals, are themselves channels or "carriers" (Sahlin and Wedlin 2008, pp. 228-229) for EQA policy dissemination. As we showed in the chapter "National Evaluation Systems", the number of national evaluations and evaluators was very restricted in the 1970s, and the knowledge they generated did not feed into national or institutional politics and policy in any substantial way; it seems as not very much brokering or dissemination was taking place. This has changed, but the number of actors who are now involved in policy brokering and act as carriers of higher education EQA policy between Europe and Sweden is still rather small. They move between employment at HEIs, the national agencies, the Ministry of Education, and other influential organisations. This means that the governing power within Sweden is quite concentrated to these individuals: they are themselves both carriers and channels.

There are a large number of organisations, particularly European, that are involved in, or more specifically work with, EQA issues in higher education. Although the informants did not mention all possible organisations, it was nevertheless clear that comprehensive discussions and other types of policy work are broadly conducted in this respect. Dissemination of EQA policy seems to run through organisational links between similar actors and/or functions in the European and international contexts and the Swedish context. Politicians meet and disseminate policy to other politicians; national agency staff and quality experts meet and disseminate EQA policy to others in similar organisations, positions, etc. We interpret this to mean that the channels between European and global policy spaces and Sweden appear to be quite insulated from each other. But when we add the internal Swedish dissemination channels to the European/global channels, there is some evidence that EQA policy nevertheless is disseminated rather widely, all the way into Swedish higher education institutions, and the SHEA plays a significant role in this respect. (See Fig. 1)

\footnotetext{
${ }^{5}$ Swednet is a formal Swedish network for pedagogic development in higher education (Swednet n.d.).
} 


\section{Discussion}

Our findings show that the ENQA membership, or rather the revoked membership, was presented as an essential issue in the national EQA policy processes. After having been one of the early members, the Swedish national agency was denied membership in 2014. This status was a result of the 2011-2014 EQA system and came to be portrayed as a national and international embarrassment. We think this is a clear example of how the open method for coordination works. The ENQA membership requirements are tied to the adherence of the ESG for aspiring members, and the ESG are examples of: "jointly established measuring instruments (statistics, indicators, guidelines); benchmarking, i.e. comparison of EU countries' performance and the exchange of best practices (monitored by the Commission)" (EUR-Lex n.d.). We have also shown that becoming a full member again was framed as an important political goal and used as a way to re-establish the lack of national legitimacy and criticism of the 2011-2014 system. The government and the national agency SHEA did this by stressing the European EQA policy and the ESG. As Sassen (2007) emphasised, this points to the importance of the policy work needed by the nation-state to make international/global policy attractive to the national context. Not only have several nation-states come to agreements over joint standards, but individual nation-states have had to reconcile internal conflicts and interests to form a receptive national context for external policy to enter and influence the national policy.

Other means for European EQA policy to travel and influence national policies are also evident. In the case of EQA policy and practice, our study shows that meditative activities (Jacobsson 2010a, b) like taking part in European/international networks, conferences, meetings, etc. are important in governing and policy work. In relation to the ENQA membership situation, regulative and inquisitive activities also become indirectly important. This is because becoming a member means adhering to certain rules and regulations, ENQA statutes, and the ESG, which means engaging or performing activities that are in line with these requirements. Complying with the ESG also means opening up for reviews and assessments by external bodies. Taken together, these activities most likely are strong governing powers for those who aspire to become and remain members, as member agency reviews are conducted every 5 years. For Sweden, this means that when the SHEA applies for a new membership, such activities will take place, and the 2016 national EQA system was designed in line with the ENQA membership requirements, which we come back to in the chapter "Re-launching National Evaluation and Quality Assurance: Expectations and Preparations". Knowledge carried by the policy brokers about how to design the Swedish EQA system to be in line with the ENQA requirements have been a condition for European policy to enter Sweden and hence influence national governing of higher education.

This EQA policy travels well through the channels we have described and through the governing activities (Jacobsson 2010a, b) we discussed above. In these encounters (conferences, networks, etc.), knowledge about EQA is exchanged, 
learned, and brokered. Freeman and Sturdy (2014) proposed that three forms of knowledge are activated in policy processes: embodied, inscribed, and enacted. We find that all three forms are probably present in the dissemination processes and channels. The policy brokers bring experiences of EQA work with them to meetings and conferences, which is akin to embodied knowledge that travels with "carriers" (Sahlin and Wedlin 2008, pp. 228-229). Inscribed knowledge is present in the ESG, in formal presentations, reports, and papers circulated and disseminated, and this kind of knowledge is easy to move and reproduce. Enacted knowledge is present in the actions taking place, for example, when presentations and reports are discussed and translated to fit into new contexts.

The exchange of EQA knowledge is often done by comparing national models and systems, both entire education systems and specific EQA systems. We find that comparisons are important as a condition for European EQA policy influence in higher education in that they are necessary for making adjustments in line with the ESG. By exchanging knowledge and experiences of how different national (regional) EQA systems are designed so as to be in line with the ESG, national policy brokers may bring this knowledge "home" and influence the national policy context. Comparisons are also used as a means to know what in the dissemination of EQA (and other) policies is of interest, useful, and possible to get acceptance for in a national context. In the Swedish case, it is clear that a main policy driver for the development of the 2016 system was the ESG, meaning that these standards and guidelines became influential in the attempts to govern higher education institutions, a finding we will elaborate on in the chapters "Enacting a National Reform Interval in Times of Uncertainty: Evaluation Gluttony Among the Willing" and "Re-launching National Evaluation and Quality Assurance: Governing by Piloting".

Since 50 quality assurance agencies are full members of the ENQA and comply by its statutes, the EGS arguably hold a dominant position in the field of EQA policy in European higher education. The ESG acquire increased policy and governing power in this circulation of EQA ideas, as described by Sahiln and Wedlin (2008). The ESG are discussed, read, and worked with in relation to EQA systems designs. Through this kind of circulation of ideas carried by interested and influential policy elites, the ideas become attractive or fashionable. With reference to Czarniawska and Sévon (2005), Sahiln and Wedlin write about fashion:

Fashion guides imitation and the attention of actors to specific ideas, models, and practices, and fashion identifies but also creates what is appropriate and desirable at a given time and place. This leads organizations to adopt, but also to translate, these ideas, thus changing both what is translated and those who translate. (Sahlin and Wedlin 2008, p. 222)

The number of actors and people involved in EQA policymaking and dissemination is noteworthy. We only portray one comparatively small country. Considering the European and Bologna context of higher education in total makes us aware of the large number of people who must be involved in these policy activities and the 
dissemination of European EQA policy to the different European Union countries as well as inside these countries. Lingard and Rawolle (2011) discussed this growth and dispersion of politics and policy in terms of a rescaling process that we find is a useful characteristic for EQA policy as well:

It is the growing importance of this hybrid mix of global and national factors that we refer to as a rescaling of educational politics and policies, into which national policies and their effects are increasingly drawn and reconstituted in a global field of comparison. (Lingard and Rawolle 2011, p. 492)

They also argue that:

Another productive way of conceptualising this rescaling is in respect of the relocation of political authority-'outward toward supranational entities and inward toward subnational groups.' (Rosneau and Czempiel 1992, pp. 2-3, in Lingard and Rawolle, 2011, p. 490)

In this chapter, we do not exactly point to where the political authority is located or if it is relocated, but clearly political authority concerning EQA in higher education now has a firm base within the ENQA at the European level. The location or relocation within Sweden has yet to be explored fully, but a tendency is re-centralisation, despite the intentions of the previously mentioned autonomy reform. We have noted that the ASHEI has become an increasingly powerful organisation that tries to bring about common policies for the HEIs in Sweden in several areas (e.g. resources, employment, organisation, internal governance; ASHEI n.d.) in the wake of the "freedoms" of the autonomy reform. This points to efforts to centralise within the HEI sector itself, where individual HEIs adjust to the agenda set by the ASHEI. An additional example of centre-local relocation may be the government's recent decision to commission the SHEA to evaluate and quality assure all activities at the HEIs, including research (Government Office 2017). This is a new development that shifts authority and governing of research from the HEIs to the national authority (the State).

\section{Finally}

In pursuing the tendency to relocate authority within the higher education sector, we find the vice chancellors to be an important group, as they occupy a central function at higher education institutions concerning EQA policy and practice. In their capacity of being the executive leaders of the higher education institutions, they may be rather influential in EQA matters within their respective institutions. In the next chapter, their views of the mission of the university, of quality in higher education, and of national EQA are described and analysed. 


\section{References}

Adamson, L. (2013). Kvalitetsutvärdering av högre utbildning - en kritisk granskning av det svenska systemet framtagen på uppdrag av SNS Utbildningskommissionen [Quality evaluation of higher education - A critical review of the Swedish system as a commission for the SNS's Educational Committee]. Stockholm: SNS.

Ala-Vähälä, T., \& Saarinen, T. (2009). Building European-level quality assurance structures: Views from within ENQA. Quality in Higher Education, 15(2), 89-103.

Arroy, E. (2014, March 7). SFS: Utvärderingen av våra utbildningar fungerar inte (Evaluation of our higher education does not work). Dagens Arena. Retrieved March 10, 2014, http://www. dagensarena.se/opnion/sfs-utvarderingen-av-vara-utbildningar-fungerar-inte/

ASHEI (2014). Hemställan om åtgärder avseende kvalitetssystem för högre utbildning. 201404-11, Dnr 14/029. [Request about actions concerning quality systems for higher education]. Retrieved August 12, 2015, http://www.ASHEI.se/publicerat/skrivelser

ASHEI. (n.d.). Sveriges universitets- och högskoleförbund. http://www.ASHEI.se. Accessed 5 Aug 2017.

BusinessEurope. (n.d.). Our mission. https://www.businesseurope.eu/mission-and-priorities. Accessed 6 July 2017.

Czarniawska, B., \& Sévon, G. (Eds.). (2005). Global ideas: How ideas, objects and practices travel in the global economy. Malmö: Liber and Copenhagen Business School Press.

Dagens Arena. (2014, March 3). Sverige utesluts ur utbildningsnätverk (Sweden is excluded from education network). http://www.dagensarena.se/innehall/sverige-utesluts-ur-utbildningsnatverk/. Downloaded 4 March 2014.

EHEA. (n.d.-a). www.ehea.info. Accessed 19 Nov 2014.

EHEA. (n.d.-b). www.ehea.info/article-details.aspx?/Articleid=24. Accessed 19 Nov 2014.

Enders, J., \& Westerheijden, D. F. (2014). Quality assurance in the European policy arena. Policy and Society, 33(3), 167-176.

ENQA. (2009). Standards and guidelines for quality Assurance in the European Higher Education Area (3rd ed.). Helsinki: ENQA.

ENQA. (2010). ENQA: 10 years (2000-2010). A decade of European cooperation in quality assurance in higher education. Helsinki: ENQA.

ENQA. (2012). Letter from Achim Hopbach, President of ENQA, to Dr. Lars Haikola, University Chancellor and Head of the Swedish National Agency for Higher Education, 17 September, 2012.

ENQA. (2014a). Letter from Padraig Walsh, President of ENQA, to Lars Haikola, University Chancellor of the Swedish Higher Education Authority, 25 February, 2014.

ENQA. (2014b). Standards and guidelines for quality Assurance in the European Higher Education Area (ESG) (Endorsed by the Bologna Follow-Up Group in September 2014). Helsinki: ENQA.

ENQA. (2015). Statutes of the European Association for Quality Assurance in Higher Education. Retrieved April 2018, http://www.enqa.eu/wp-content/uploads/2016/05/ENQA-Statutes2015-EN.pdf

Ericsson, M. (2014). Analys av Universitetskanslersämbetets utvärderingar av utbildningskvalitet år 2011-2014 [Analysis of the SHEA's evaluations of education quality years 2011-2014]. Stockholm: KTH. e-mail: merics@kth.se.

EUR-Lex. (n.d.). Open method of coordination. http://eur-lex.europa.eu/summary/glossary/open_ method_coordination.html. Accessed 27 Dec 2016.

Franke, S., \& Nitzler, R. (2008). Att kvalitetssäkra högre utbildning - en utvecklande resa från Umeå till Bologna. [To assure quality in higher education. A developmental journey from Umeå to Bologna]. Lund: Studentlitteratur.

Freeman, R., \& Sturdy, S. (2014). Introduction. In R. Freeman \& S. Sturdy (Eds.), Knowledge in policy. Embodied, inscribed, enacted (pp. 1-17). Bristol: Policy Press. 
Government Office. (2014). Press release 8 April 2014. Harriet Wallberg Henriksson utreder systemet för kvalitetssäkring av högre utbildning [Harriet Wallberg Henriksson investigates the national quality assurance system in higher education]. Retrieved April 10, 2014, http:www. regeringen.se/sb/d/18276/a/238291

Government Office. (2017). Press release, 7 July 2017. Kvalitetssäkring av forskningsmiljarder förstärks [Strengthend quality assurance of research billions]. Retrieved July 7, 2017, http://www.regeringen.se/pressmeddelanden/2017/07/kvalitetssakringen-av-forskningsmiljarderforstarks/

Government Petition 2015/2016:76. Kvalitetssäkring av högre utbildning [Quality assurance of higher education]. Retrieved March 22, 2016, http://www.regeringen.se/rattsdokument/ skrivelse/2015/12/skr.-20151676/

Grek, S., \& Lawn, M. (2012). Europeanizing education. Governing a new policy space. Oxford: Symposium Books.

Haikola, L. (2013). Reflektioner kring det nuvarande utvärderingssystemet. Erfarenheter 2011-september 2013 [Reflections on the present evaluation system. Experiences 2011-September 2013]. Stockholm: SHEA.

Jacobsson, B. (2010a). Making sense of Europeanization. Jerusalem papers in regulation \& governance (Working Paper No. 11, June 2010). Jerusalem: The Hebrew University, Jerusalem Forum on Regulation \& Governance.

Jacobsson, B. (Ed.). (2010b). The European Union and the Baltic States. Changing forms of governance. London: Routledge.

Kauko, J. (2012). The power of normative coordination in the Bologna process: How universities learned to stop worrying and to love quality assurance. Journal of the European Higher Education Area, 2012(4), 23-40.

Kettis, Å. \& Lindberg-Sand, A. (2013). Det svenska kvalitetssystemets kval - en dialog från olika utgångspunkter [The anguish of the Swedish quality system. A dialogue from different viewpoints.] Högre utbildning 3(2), 139-149.

Kristensson, D. (2010). From the First Pilot Projects to the Founding of ENQA (1994-2000). In ENQA: 10 years (2000-2010). A decade of European co-operation in quality assurance in higher education (pp. 5-7). Helsinki: ENQA.

Lawn, M. (2006). Soft governance and the learning spaces of Europe. Comparative European Politics, 2006(4), 272-288.

Lawn, M., \& Lingard, B. (2002). Constructing a European policy space in educational governance: The role of transnational policy actors. European Educational Research Journal, 1(2), 290-307.

Lindgren, J., \& Rönnberg, L. (2015). The emotional politics of policy processes. Governing in and by quality evaluation reforms in Swedish Higher Education. Paper presented at the European Conference for Educational Research in Budapest, 8-11 September, 2015.

Lingard, B., \& Rawolle, S. (2011). New scalar politics: Implications for education policy. Comparative Education, 47(4), 489-502.

Lundmark, A., \& Sjölund, M. (2012). Håller utvärderingsmetoden tillräcklig kvalitet? En uppföljning vid Uppsala universitet av Högskoleverkets system för kvalitetsutvärdering 20112014. Första omgången [Is the quality of the evaluation model good enough? A follow-up at Uppsala University of the SNAHE's system for quality assurance 2011-2014. First cycle]. Uppsala: Uppsala universitet, Enheten för kvalitet och utvärdering.

Maassen, P., \& Stensaker, B. (2011). The knowledge triangle, European higher education policy logics and policy implications. Higher Education, 61(6), 757-769.

Ministry of Education. (2015). Promemoria. U2015/1626/UH. Kvalitetssäkring av högre utbildning [Quality assurance of higher education]. Retrieved April 18, 2018, http://www.regeringen. se/rapporter/2015/03/u20151626uh/

Mycklebust, J.P. (2012, May 6). Quality assurance regime fails to meet European standards. UniversityWorldNews. http://www.universityworldnews.com/article.php?st ory $=20120503164105608$. Accessed 8 July 2015. 
Ozga, J., \& Jones, R. (2006). Travelling and embedded policy: The case of knowledge transfer. Journal of Education Policy, 21(1), 1-17.

Ozga, J., Dahler-Larsen, P., Simola, H., \& Segerholm, C. (Eds.). (2010). Fabricating quality in education. Data and governance in Europe. London: Routledge.

Parliament Decision 2015/2016:155. Riksdagsskrivelse [Parliament decision]. Retrieved 18 April, 2018, https://www.riksdagen.se/sv/dokument-lagar/dokument/riksdagsskrivelse/ riksdagsskrivelse-201516155_H30K155

Parliament Minutes 2013/2014:81. Svar på interpellationerna 2013/14:314 och 319 om kvalitetsutvärderingssystemet för den högre utbildningen [Answer on parliamentary questions 2013/14:314 and 319 concerning the quality assurance system in higher education]. Retrieved March, 2014, http://www.riksdagen.se/sv/Dokument-Lagar/Kammaren/Protokoll/ Riksdagens-snabbprotokoll-2013_H10981/

Parliament Standing Committee on Education 2015/2016:UbU9. Kvalitetssäkring av högre utbildning [Quality assurance of higher education]. Retrieved March 22, 2016, https://data.riksdagen.se/fil/BFE0EB56-062B-4AA8-BBE3-794EE45BB9CF

Rosneau, J. N., \& Czempiel, E.-O. (Eds.). (1992). Governance without government: Order and change in world politics. Cambridge: Cambridge University Press.

Sahlin, K., \& Wedlin, L. (2008). Circulating ideas: Imitation, translation and editing. In R. Greenwood, C. Oliver, K. Sahlin, \& R. Suddaby (Eds.), The SAGE handbook of organizational institutionalism (pp. 218-242). Thousand Oaks: SAGE Publications.

Sassen, S. (2007). A sociology of globalization. New York: W. W. Norton \& Company, Inc.

Sedigh, M. (2013). External quality assurance and its impact on internal quality management. A review of the Higher Education Authority's evaluation system for quality assessments 20112014. Stockholm: Swedish Higher Education Authority, and the author (status unclear).

Segerholm, C., \& Hult, A. (2015). Manoeuvring in the European quality landscape: The significance of ENQA policy in governing Swedish higher education. Paper presented at the European Conference for Educational Research in Budapest, 8-11 September, 2015. Umeå: Umeå University, Department of Education.

Segerholm, C., \& Hult, A. (2017). Channels for European quality assurance policy in higher education - The Swedish example. Paper presented at the European Conference for Educational Research in Copenhagen, 22-25 August 2017. Umeå: Umeå University, Department of Education.

Shattock, M. (Ed.). (2014). International Trends in University Governance. Autonomy, selfgovernment and the distribution of authority. Oxon: Routledge.

SHEA. (2014). Personal communication with SHEA Central staff, May 2014.

SHEA. (2016a). Annual report for 2015. Stockholm: SHEA.

SHEA. (2016b). Guidelines for reviewing quality assurance procedures of higher education institutions. Pilot study. Stockholm: SHEA.

SHEA. (2017). Annual report for 2016. Stockholm: SHEA.

SHEA. (2018). Annual report for 2017. Stockholm: SHEA.

SNAHE. (2006). Evaluation of the Swedish National Agency for Higher Education. 31 January, 2006. Retrieved July 9, 2015, http://www.enqa.eu/wp-content/uploads/2007/05/Externalreview-report-of-the-Swedish-National-Agency-for-Higher-Education-HsV-May-2007.pdf

SNAHE. (2012). Swedish National Agency for Higher Education: Review of ENQA Membership. April 2012. HSV_review-ENQA-Criteria-Report-April2012 (1).pdf

Standards and Guidelines for Quality Assurance in the European Higher Education Area (ESG). (2015). Brussels, Belgium.

Steiner-Khamsi, G. (2004). The global politics of educational borrowing and lending. New York: Teachers College, Columbia University. 
Svenska Dagbladet. (2014). SvD Opinion. Brännpunkt. Kvalitetskontroll [SvD Opinion. Focal point. Quality control]. April 13, 2015. Retrieved April 14, 2015, http://www.svd.se/ universiteten-vi-kan-skota-granskningen

Swednet. (n.d.). http://www.swednetwork.se/hem/. Accessed 22 July 2018.

Thune, C. (2010). ENQA 2000-2005: From the launch of a professional network to the success in Bologna of a new association. In ENQA: 10 years (2000-2010). A decade of European cooperation in quality assurance in higher education (pp. 9-15). Helsinki: European Association for Quality Assurance.

Open Access This chapter is licensed under the terms of the Creative Commons Attribution 4.0 International License (http://creativecommons.org/licenses/by/4.0/), which permits use, sharing, adaptation, distribution and reproduction in any medium or format, as long as you give appropriate credit to the original author(s) and the source, provide a link to the Creative Commons license and indicate if changes were made.

The images or other third party material in this chapter are included in the chapter's Creative Commons license, unless indicated otherwise in a credit line to the material. If material is not included in the chapter's Creative Commons license and your intended use is not permitted by statutory regulation or exceeds the permitted use, you will need to obtain permission directly from the copyright holder.

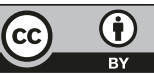




\title{
Navigating Higher Education Institutions in Times of Quality Assurance: The Assumptive Worlds of Vice Chancellors
}

\author{
Agneta Hult
}

\begin{abstract}
In this chapter, the vice chancellors' views of the idea of the university, quality in higher education, and national evaluation and quality assurance are described and analysed as parts of their assumptive worlds. A majority of all Swedish vice chancellors were interviewed, and their different and partly conflicting views are outlined as different regions of the Swedish higher education landscape. As a background, the changes to the governing of higher education in Sweden are briefly presented. The vice chancellors' assumptive worlds are discussed in relation to these transformations and to governing higher education by evaluation and as potential grounds for their common policy and action.
\end{abstract}

\section{Introduction}

In the previous chapters, we delineated the background by describing the Swedish higher education system and the former national evaluation and quality assurance (EQA) systems. We further related them to a European context. In this chapter, ${ }^{1}$ we will continue to map the scenery by focusing on the subjective understandings, or the "assumptive worlds" (Marshall et al. 1985), of Swedish vice chancellors.

We started our project, as described in the chapter "National Evaluation Systems", by gaining deeper insights into the different national EQA systems. These insights pointed to an expansion in the activities making up the EQA systems and to changes in governing by evaluations of higher education institutions (HEIs). Along with these changes, it was also obvious that higher education in Sweden was not isolated from Europe or beyond (as described in the chapter "Europe in Sweden"). The purpose, benefits, and quality of education and research at the HEIs had become matters

${ }^{1}$ This chapter is a revision and reanalysis of two conference papers: Olofsson and Hult (2015) and Olofsson et al. (2015).

\footnotetext{
A. Hult $(\bowtie)$

Department of Education, Umeå University, Umeå, Sweden e-mail: agneta.hult@umu.se 
of concern for instances far away from the universities. When taking part of documents at both the national and European levels concerning the evaluation and quality of higher education, we found an idiom and a jargon that was hard to see through. The texts concern quality, higher education, and quality assurance; at the same time, they do not touch upon what quality in higher education is or what the idea of the university is and should be. These questions were never really discussed. In light of the changing governing of higher education, we were interested in letting the Swedish vice chancellors state their views on these issues. Our focus on the actors doing the EQA led us not only to study the work of these actors but also their ideas and beliefs.

In Sweden, vice chancellors are academics with backgrounds as scholars and teachers within their respective discipline and within an academic tradition. Before 1993, the HEIs' staff elected the vice chancellor. Since 1993, the government has appointed vice chancellors after an internal selection process (SFS 1993:100). In Sweden, the vice chancellors at the universities and university colleges ${ }^{2}$ are ultimately responsible for the quality of education at their HEIs. Today, they carry out their work in a quite different institutional setting compared to some decades ago, when they were able to "mind their own business" to a large degree, without much external interference. The questions of what a university is and what it ought to be are becoming increasingly politicised. In the European Union (EU), efforts have been made to unify the educational systems, and the far-reaching political consensus in Sweden is that it is crucial that Swedish HEIs are part of these efforts. Vice chancellors in Sweden thus have to consider a multitude of international and European as well as national and regional aspects. How they navigate in these relatively new circumstances for HEIs and how they formulate their agendas are of interest and relevance for their way of governing and forming policies and practices at their HEIs and for future joint actions within their network, the Association of Swedish Higher Education Institutions (ASHEI, Sveriges Universitets- och högskoleförbund, SUHF). When elaborating on decentred governance, Bevir (2011, p. 191) argues that "[t]he flow of politics is speech and other actions". Actors' contingent beliefs are meaningful parts of governing, as "there are diverse practices composed of multiple individuals acting on changing webs of beliefs rooted in overlapping traditions" (Bevir 2013, p. 57).

In this chapter, we will take a closer look at the beliefs and ideas about the university and of quality in higher education among vice chancellors of Swedish HEIs. Close attention will also be paid to their views on mechanisms of national EQA. The vice chancellors' ideas and views will be interpreted as parts of their assumptive worlds - that is, as a "shared sense of what is appropriate in action, interaction, and choice". Assumptive worlds, argue Marshall et al. (1985, p. 90 and 114), "provide the model or skeleton and connective tissue that pulls together data from various views of policy making". Since the vice chancellors are the executive leaders at the

\footnotetext{
${ }^{2}$ The difference is primarily that universities do not need to apply for degree-awarding powers to the same extent as university colleges (Swedish Higher Education Authority [SHEA] n.d.).
} 
HEIs, we argue that studying their assumptive worlds concerning external EQA will give insights into the governing of higher education.

Next, we give a short background on national EQA in Sweden, including some important changes in the governing of higher education. This will be followed by a brief account of our methodology and of the concept of assumptive worlds. We then present the Swedish higher education landscape and national EQA, as perceived by the vice chancellors. Finally, the vice chancellors' assumptive worlds will be discussed in relation to the transforming governing of higher education in Sweden and how these "shared senses" might constitute a basis for the vice chancellors" common policy and action.

\section{Background}

Ever since the signing of the Bologna agreement, there has been a strong movement towards comparability between, and quality assurance of, the member nations' higher education systems (c.f. the chapter "Europe in Sweden"). On the European level, 50 agencies in 28 countries were being monitored by the European Association for Quality Assurance in Higher Education (ENQA) in spring 2019. On the national level, the higher education reform of 1993 (Government Bill 1992/1993:1) established a new national agency responsible for auditing the HEIs' quality assurance and development programmes. In addition to this external control mechanism, the Higher Education Act and Higher Education Ordinance demands functional forms for quality assurance within all Swedish HEIs. Thus, each HEI is obliged to organise an internal system for QA and programmes for quality development.

The higher education reform of 1993 changed many activities in all Swedish HEIs. Bauer (1996) has argued that the reform clearly expressed "a shift from steering mainly by rules and regulations, to a steering by goals and results" (p. 78). In an interview study of faculty and leadership from six disciplines at three Swedish universities, Bauer (1996) found that vice chancellors and heads of university administration were generally receptive to the reform's intentions to provide more freedom and authority to the universities, "even though several suggest that much of it is illusory and superficial” (Bauer 1996, p. 78). The widened autonomy was also followed by "increasing demands on their local statutes, more decisions, and adherent internal conflicts" (ibid.).

Today, Swedish vice chancellors and HEI teachers and staff have lived with, and seemingly become used to, many and increasingly extensive and significant external and internal EQA systems for 25 years. ${ }^{3}$ Besides the 2011-2014 EQA system, the compulsory EQA systems as such have not been subject to protests. When the 2011-2014 EQA system was imposed (in which the control function prevailed and the agency's judgement was built on reviewing the students' independent degree

\footnotetext{
${ }^{3}$ As we have demonstrated in the chapter "National Evaluation Systems", most of the national EQA systems evaluated the HEIs' internal quality assurance systems (IQAs).
} 
projects), many of the vice chancellors objected. The system was heavily criticised in the media, foremost by the vice chancellors' network ASHEI. In the chapter "Hayek and the Red Tape: The Politics of Evaluation and Quality Assurance Reform - From Shortcut Governing to Policy Rerouting", we give a more detailed analysis of the political processes leading up to the two more recent EQA systems.

Sweden is, of course, not unique in the above changes in governance. As we have demonstrated elsewhere (see Segerholm et al. 2014), the transformation of higher education in Sweden appears to follow these international trends. Jarvis (2014) argues that "QA regimes are not benign managerial instruments - they must also be understood as part of a broader series of agendas associated with neo-liberal policy prescriptions that valorise market rationality" (p. 164).

Liedman (2009) provides a historical expose of the transformation of the Swedish university. In a very condensed version, during the 1950s and 1960s, the collegial organisation received competition from bureaucratic organisation entering the Swedish universities, bringing with it a formalised and growing economic administration and several new sections, for planning and staff, for example. It also meant more power being transferred from the professors to the head of the departments. Another layer during the late 1960s and 1970s was the idea of democratisation, chiefly in the sense of student influence or, more accurately, representation in the departments' new boards. Today, these boards have mostly been abolished, but students still can be represented in education programme committees and in boards at the faculty level. The next layer entering the HEIs in the 1980s and 1990s was a focus on leadership and the importance of charismatic leaders for the HEIs, faculties, and departments. From the beginning of the twenty-first century, the entrepreneur made its entrance into the HEIs and contributed to a shift, where "higher education and research is a central part of the surrounding business world, yes maybe the most important engine" (Liedman 2009, p. 9). With the Bologna agreement, the ties between higher education and the business world were strengthened, and employability became the new buzzword.

The transformation of higher education in Sweden has been subject to much debate within the academy, above all among social scientists. Conferences have been arranged, and books and special feature issues have been published, on the transformed field of HEIs (e.g. Rider et al. 2013; Ahlbäck Öberg et al. 2016; Karlsohn 2016; Wedlin et al. 2017). Even a novel taking place at an old university with the sub-heading "When the university lost its freedom", authored by a former political science professor - debates these changes (Lewin 2017). In their analysis of Swedish higher education policy texts from 1992 to 2007, Ljunggren and Öst (2008) found that the language in higher education policy has been reduced over time, "owing to the hegemonic tendencies of the discourse of economic globalization" (p. 13). Traditional academic ideals and justifications had been superseded in favour of this discourse and whose new key words include economic development, competition, mobility, comparability, and life-long learning. Hasselberg et al. (2013) further discusses professionalism and discretion and argues that professionals today have been turned into administrators: they are expected to be "doers" without individual ideas on how things should be done or why. As a result, "the new 
professionalism lacks the central ingredient of a value-based standard of good work" (p. 139).

Increasing expectations from outside the academy, external funding bodies, employers, and partners from industry are putting pressure on academic life and work (Elmgren et al. 2016). Hasselberg et al. (2013) argue that the governments' and regional actors' ambition is to regulate and adapt the system of higher education and research to meet the demands of the global economy, of employability for the students, and new patents and products for the international market, "the driving force is the production of knowledge as an engine of economic prosperity and growth" (Hasselberg et al. 2013, p. 4, italics in original). In a case study of the Swedish Knowledge Foundation (KK-stiftelsen) and its mission to modify the new universities (established after 1977) into motors of regional development, Hyvönen (2013) found that the vice chancellors at these HEIs were enthusiastic and optimistic. For instance, the then-chief executive officer of the foundation stressed that "our meetings with the vice chancellors testify to the strong bonds between the vice chancellors and the representatives of the business community" (quoted in Hyvönen 2013 , p. 101). These bonds seemed more easily established at the new regional university colleges, where research funding is scarce and cooperation with local businesses may be appealing.

The transformed field of higher education will most likely change the notion of quality as well. Hasselberg et al. (2013) predict that quality evolves into a supply and demand definition, i.e. "the notion of quality and demand merge" (p. 3).

As have been shown, quality in higher education has for long been an object of interest yet elusive and hard to exhaustively define. Scholars have identified many aspects when trying to capture the essence of quality. Harvey and Green (1993), for example, gave an account of five basic forms, while Dahler-Larsen (2008) investigated five perspectives on quality by analysing which quality criteria, types of problem, operationalisations, forms of normativity, and matters of avoidance they represent. Cole (2011) discussed educational quality in terms of research and teaching and suggested 13 quality indicators.

In Sweden, the government's higher education reform bill of 1993 (Government Bill 1992/1993:1), which had the subtitle "Freedom for quality", was motivated by a need to strengthen Sweden as a "nation of knowledge" (Bauer 1996, p. 77). Bauer (1996) found that the university leadership often expressed quality in terms of basic, solid work and a conscious ambition to develop this work, as an improvement that must come from within the university. They problematised the balancing between the internal academic criteria and the external societal demands, and "[n]o one directly formulated quality in terms of goal- fulfilment" (Bauer 1996, p. 78). To ensure and enhance quality, the university leadership emphasised dialogue between teachers as well as between teachers and students. The teachers, on the other hand, demonstrated great uncertainty when asked about quality in higher education and also admitted that they had not thought much about it. When answering questions about quality, the most common answer was that quality is related to the connection between research and teaching. Bauer (1996) commented that quality "is often taken for granted in the university" (p. 79). This is hardly the case for Swedish 
university teachers today after taking part in internal quality assurance (IQA) and national EQA systems since the beginning of the 1990s.

In the next section, the method and data will be set out, and the contemporary Swedish higher education landscape as described by the vice chancellors' will be presented.

\section{Methodology and Data}

Marshall (1985) underlines the potential of using interviews as a way of entering into the assumptive worlds of the interviewees:

Using their utterances as a key to understanding their assumptive worlds will provide insights into policymakers' worldviews, their ways of understanding and wending their way through their own world to achieve their own ends. (Marshall 1985, pp. 9-10)

Following Marshall et al. (1985), who interviewed policy makers, we argue that our interviews with vice chancellors reflect "[h]ow these elite act, with what understanding, values, and senses of what is possible and proper" (Marshall et al. 1985, p. 93). They have common experiences and values related to their previous academic history and current situation. In line with Marshall et al.'s argument about policy makers' assumptive worlds, we assume that vice chancellors' perspectives on higher education "limit the range of options and focus debate within certain understood priorities" (Marshall et al. 1985, p. 110). Assumptive worlds reflect shared meanings that, in this case, represent the vice chancellors' common sense and help them decide what is appropriate and possible and what is not. This also involves a common language that reflects a "taken-for-granted framework within which policy making occurs" (Marshall et al. 1985, p. 91).

Also arguing for studies of meanings and beliefs, Bevir (2013, p. 70) encourages social science researchers to focus on "the social construction of practices through the ability of situated individuals to create and act on meanings". The decentred approach he offers is aimed at studying social life through the meanings "that infuse the beliefs and practices of individual actors" (p. 70).

It is to reveal the contingent and conflicting beliefs that inform the diverse actions that constitute any domain of social life. (Bevir 2013, p. 70)

During spring and autumn 2014, we interviewed 33 vice chancellors of Swedish HEIs. The interview questions forming the basis for this chapter were: What is a university/university college? What makes it a university/university college? What is quality in higher education? How is it possible to reach that quality (i.e. quality as described by the informant)? Can evaluation and quality assurance enhance the quality of higher education? When asked these rather wide questions, the vice chancellors often appeared surprised and a bit disturbed or confused. Like the university teachers in the beginning of the 1990s (Bauer 1996), they seemed unprepared and not used to talk about higher education and quality in this (abstract) way. 
The vice chancellors' answers were analysed at three separate occasions: one for identifying the different ideas of the university, one for arriving at the different views of quality in $\mathrm{HE}$, and finally one for determining their line of reasoning about EQA. A merger of the two first analyses is presented in this chapter, forming the Swedish higher education landscape, which is described as comprising four diverse regions. The analysis of their views on evaluation and quality assurance will then follow as a special aspect of this landscape. Quotations from the vice chancellors are used to illustrate the different regions.

\section{The Higher Education Landscape According to the Vice Chancellors}

The vice chancellors are navigating their institutions through the previously described changed governing of Swedish higher education. In the following, we present the different ideas on higher education expressed by the vice chancellors. We will present them metaphorically as different regions within the higher education landscape. We focus on the qualitative differences that constitute the contemporary higher education landscape in Sweden, rather than on giving a quantitative account of how many vice chancellors represent each perspective. The vice chancellors sometimes moved across this landscape and expressed more than one perspective. Overall, the vice chancellors understood the HE landscape as fulfilling the task of producing new knowledge and communicating it to new generations. This was often the first answer to the question of what a university/university college is. However, when asked to elaborate on their answers, four distinct regions of this landscape appeared.

\section{The University as Freedom and Integrity}

This region accentuates the university idea as one of freedom and integrity for higher education institutions.

That we can protect the freedom to be able to think freely, deciding on content and forms for education and research: that's our question, and that is the important question for a university. (VC 3)

It is essential that the building of new knowledge be driven by researchers and not by politicians or other external interests. The absence of directed research enables the research process to take unpredictable and interesting directions that would not be possible if steered from other instances.

The freedom of research, the possibility to choose both methods and presentation and to a great degree objective and focus: that change, and development of new knowledge are driven by researchers and academics and not by political issues, for example. (VC 31) 
The importance of critical dialogues among colleagues was emphasised, as were encountering and confronting knowledge. The university is a place characterised by "a positive, creative, knowledge-focused environment" (VC 6), where different views and perspectives can be brought together. "It should be a kind of melting pot", meant VC 6.

The free spirit characterising research and collegial dialogue among researchers also benefits the quality of education at HEIs. Quality in higher education means that students should be offered an education that opens up their minds and ways of thinking.

....at a university, you don't educate and teach about truths but widen the students' perspective and teach students to put questions to the surrounding world and also to themselves.

That is what I think characterises a university. (VC 13)

Teaching with quality is believed to produce education that generates and advances students' ability to analyse and critically reflect on problems. These abilities should be nurtured during the educational programme and will be generated when acknowledged research is utilised in education, to give students opportunities to develop their reflective abilities by burrowing into research, trying different avenues, and thus critically valuing what they are experiencing: "It's incredibly important that all our teachers, from lecturers to professors, are doing both research and teaching so that our students always get to experience the best" (VC 26). However, this kind of quality, with an education that is deeply rooted in lecturers' own research, is sometimes a problem for the university colleges. Their possibilities for securing research funding, and thereby having lecturers who are both researchers and teachers, are less than those of the universities. One of the vice chancellors from a university college clearly stated that "the reduced funding also causes a deterioration of the possibilities in education" (VC 31).

By graduation, students should manifest sustainable qualities that can be used in future occupations and societal engagements as a whole. Stressing these more generic skills, such as analytical ability, might also mean that universities have to struggle against - and not give in to - commercial and industrial demands that would prefer universities to customise students according to a presently narrow concept:

They [the companies] really would like to have 'turnkey component students' for existing production, students who are directly useful in production today, but I think it's equally important, to say the least, that they are useful or fit the labour market in 10 or 20 years. Therefore, a stable ground is the absolute most important thing to give them. (VC 10)

Evaluating the quality of higher education means providing information of the students' development during the educational process, such as by reviewing if the HEIs "follow up on students' abilities", including "the ability to make critical analysis" (VC 3).

In a special part of this region of freedom and integrity, quality of higher education meant refining the unique gifts with which students enter the education; that is, "they are educated towards creating something out of their own minds" (VC 32). 
The first step of reaching quality is an accurate selection process that can succeed in picking the most talented students. In this selection process the initial qualities are specified as technical skill, musical expression, ability to analyse and so on (VC 34)

To strengthen the students' individual talents and visions, the education must give them room to develop their capacities and interests in close encounters with the teachers and with the institutions' research. Students should also meet a lot of different role models and have the opportunity to learn from different ways of practising their speciality.

Quality for us is these different aspects: high quality when they enter [the education]; very high competence in the teachers and material, collaboration, and media; and the surrounding society, the physical nearness to professional experts in their field. (VC 34)

It is important for an educational institution to be up to date and be "perceptive of innovations and support new interesting things" (VC 33). Thereby, the HEIs' freedom to choose their own lines of research is important as well. It is also a matter of time and resources spent tutoring the students for them to gain a certain expertise and confidence in their chosen field. The goal is " $[\mathrm{t}]$ hat you become confident and safe in your area, safer, so you grow in your studies" (VC 35). This self-reliance will be built when resources and time are spent on encouraging the students to question and challenge their own creativity and reflect together with supportive and more experienced teachers.

\section{The University as Societal Progress}

Close to the above region of the HE landscape characterised by freedom and integrity for HEIs, we found a second region emphasising the HEIs' function of developing the community and being conducive to societal progress: "The institutions have an important task in providing society with knowledge and also contribute to positive change in society" (VC 29). In this region, research and tertiary education are emphasised as a driving force for social development and change. Such ideas critically reflect the HEIs' responsibility:

This model with a core of research and education and the task of collaboration and development, of course it has proven historically to be a survivor (...) the characteristics are, you have stability, and you have the freedom to examine our contemporary society, including your own responsible authority, if it is a public university. At the same time, you are perhaps the most vital force for community development and social change. (VC 2)

The HEIs play a key role for national progress due to their efforts to educate the next generation and their search for new knowledge. In this mission, it is important to protect "the academic integrity" (VC 17) to "make our own decisions, so this is a crucial thing for the university" (VC 2). This concern, as we can see, relates to the above presented region in its wish to protect academic integrity. This can therefore be said to constitute a common part of the assumptive worlds among Swedish vice chancellors, a part of their shared meanings or common sense. 
This region is characterised by its emphasis on the HEIs' contribution to society through research and education and thereby their commitment to the long-term mission to change society in a positive way.

There is no other actor in society that really can take on this responsibility of bringing together, taking a long-term approach forward: a responsibility the other players can't take because they are more short-term oriented. Politically, or other forces, commercial forces, can't take this responsibility. (VC 9)

Through their long-term and future-oriented research, the HEIs can educate and prepare the next generation with the most recent knowledge. Furthermore, the HEIs must establish and stay in contact with other actors in society and be able to prepare and advance these actors' ability to "utilize the new force that the newly graduated students represent" (VC 9). As such, there is ever-greater pressure on universities to interact with and prepare for a sustainable society as well as "to generate understanding for the important challenges and linkages at hand" (VC 20).

The quality of higher education in this region characterised by development optimism implies an institution with an education that gravitates towards preparing students to become overachievers, based upon international comparison. As one vice chancellor expressed the demands, "Well, of course it is important with a high level of quality internationally and that it can be compared with the best educations internationally" (VC 8). Quality is produced and identified in collaboration and comparison with high-ranking international and national universities and research communities. Well-functioning collaboration enables the international recruitment of skillful teachers, researchers, and students, and to VC 2: "there is nothing like having large international recruitment at your university" (VC 2). Comparison and collaboration with prestigious international universities are important for quality assurance and for setting standards for the universities' internal quality assurance systems, and they also inspire and incentivise improved contributions by the staff and students. In addition, this international collaboration, besides benefitting a university's research, education, and quality assurance, is also seen as enabling Swedish scholars and tutors to "influence the EU agenda for research and education" (VC 2). Evaluations of quality of higher education in this part of the landscape thus involves engaging in qualified international networks, as "they give us advice, we present our strategies and our thoughts to them, and they give us their views on what we should reflect on" (VC 2).

\section{The University as Regional Benefit}

A third region in the higher education landscape concerns the regional benefit and profitability. This region is somewhat related to the former, in the sense that the knowledge produced at the HEIs should benefit society. However, in contrast to the former region, this region is more directed towards economic and regional profitability. These institutions are important to vitalise the region: 
University colleges in this regional perspective have an extremely important role, not least for the supply of competence for key functions in the region. This can be seen, for example, in our catchment area, where 70 per cent of our students come from this region. (VC 26)

This benefit also seems to be mutual. Regional enterprises can be very important for the HEIs. Enterprises and regional driving forces thus indirectly can exercise influence since they can contribute to smaller universities' research and development funding. Hence, HEIs can receive new funding by being receptive to regional needs. One vice chancellor expressed this as follows:

New universities or fairly new university colleges [like ours] are a bit closer to 'put our ears to the ground' and be part of situations where things happen. It is relatively easy to get in contact with us. (VC 30)

Producing "utilizable research" (VC 1) is emphasised as being important and worthwhile, and no contradiction seems to exist between basic and applied research; "the benefit extends from the ivory tower and out to the garage" (VC 25). These benefits may be threatened by the recent merger of smaller HEIs into bigger units, as " $[\mathrm{t}]$ hey risk losing the unique regional conditions and it gets worse for the regions" (VC 28).

Also in this region of the HE landscape, quality in higher education can be illustrated as a form of education that conveys to the students an ability to make critical analyses; "these cognitive qualities that the society needs" (VC 30). The HEIs that succeed in doing this perform educations with quality.

\section{The University as a State Authority}

The final region in the Swedish higher education landscape characterises HEIs mainly as an official state authority. Here lies the formal and assigned commission that vice chancellors as representatives of an authority are obliged to perform, according to the Higher Education Act and Higher Education Ordinance. The HEIs are responsible for producing knowledge and giving students a good education.

It is actually to have an official mission in terms of education and research, and accounting for knowledge production and knowledge transfer, exercised according to constitutional law in terms of quality, research, and education. (VC 24)

Quality in higher education is equated with achieving (or exceeding) the Swedish national goals for higher education. In other words, if students taking a specific programme or degree reach the national goals for that programme or degree, their education has been of high quality. The content and competences are not specified for this kind of quality; rather, such goals were taken for granted. "Quality is related to the goals you specify", and these goals are predefined "[a]ccording to the quality assurance system of the SHEA" (VC 23, both quotes). 
As mentioned, quality in education is often taken to be of value to society. However, this region also has conceptions of educational quality that are as valuable to the individual student:

From the point of view of the student's period of study here, education should be as valuable as possible for them from all angles. It should be an investment in their future, and that's the core point in the quality concept: that we make it as good as it can ever be. That it is useful for the student. (VC 14)

This type of quality in higher education can be determined through student questionnaires and course evaluations. The results of these assessments are taken seriously: "if they answer that they have not come in contact with research, we can take a look at these courses" (VC 14). According to the vice chancellors, IQAs and national EQA systems also may identify and help improve the quality of education. Both are developed in agreement with the national and local goals, which therefore means a close follow-up on the goals. The vice chancellors often reported and elaborated on ambitious IQA systems developed by their institutions to anticipate the national evaluation and hopefully adjust the quality of education before being evaluated by the SHEA.

In this section, we have sketched the higher education landscape in Sweden as one comprising four regions. These perspectives of HEIs and quality in higher education constitute the vice chancellors' assumptive worlds, in the sense that they are well known and openly display "what is possible and proper" (Marshall et al. 1985, p. 93). Even though not all of the vice chancellors sympathised with all of these perspectives, in contemporary Sweden, the perspectives are approved ways of stating the idea of the university and thus to base higher education policy on. In the next section, we will take a closer look at the vice chancellors' approaches to EQA.

\section{National Evaluation and Quality Assurance}

Can external evaluation and quality assurance promote quality in higher education? In all different regions of the higher education landscape, it seems, according to the vice chancellors, that the national EQA systems are drivers for quality improvement and thus part of the vice chancellors' assumptive worlds. However, the kinds of quality that should be evaluated may differ.

When the interviews were performed, the vice chancellors' most recent experience with external EQA was the national system operating between 2011 and 2014. As described in the chapter "National Evaluation Systems", this system was heavily criticised by the vice chancellors' own network, the ASHEI. The criticism foremost concerned the strong emphasis placed on students' independent degree projects for deciding the quality of a special educational programme or discipline: "They measure far too narrowly (...) have to look to more breath than the degree project" 
(VC 8). Despite this criticism, in their interview answers, the vice chancellors quite often suggested that this national EQA system operated to promote quality anyhow. One motivation behind these somewhat puzzling answers was, "When we know we are going to be evaluated, we shape up" (VC 25). The decisions from the agency are high stakes, and for the HEIs, a fail decision can mean that they will lose their right to award degrees for an education programme or a discipline.

Carrying out the national EQA means initiating many activities at the HEIs. The self-evaluation that has been a compulsory part of all national EQA systems forces the HEIs to examine and describe in detail their own institution and work. Among other things, it makes them reflect on how their HEI is organised and engage in "the collegial academic dialogue about why the results are the way they are, or why it seems to be these effects, how can we understand this?" (VC 24). Another element of the EQA systems that the vice chancellors seemed to appreciate was having external peers looking at and commenting on their HEI: "that someone from the outside takes a look at the work you do is always positive. You catch sight of things you have forgotten" (VC 27). The vice chancellors meant that one important thing for an EQA system is that it is an element that sustains improvement. This statement is related to one of the ENQA's reasons for excluding the 2011-2014 EQA system, which was that this system did not give any recommendations for improvement (Swedish National Agency for Higher Education 2012). Most of the vice chancellors endorsed this critique: "it was explicitly not enhancing but controlling" (VC 1). "It gave a very meagre material for quality enhancement" (VC 6). Instead, the vice chancellors wished for an evaluation and a report with recommendations that they could use directly for improving their internal quality assurance. This was also the intention in a proposition sent to the Ministry of Education from the ASHEI in 2014.

Where the national EQA system directs its interest is of great significance, and the vice chancellors had proposals for other important matters to evaluate, including more qualitative aspects like whether the students develop their independence during their studies. Furthermore, concerning the EQA system's focus, some of the vice chancellors had noticed that when the students' independent degree projects were the focus of the national system, many HEIs invested their efforts into preparing the students for this exercise. This can be an example of the direct governing effect that the EQA systems have on the HEIs - that is, what the EQA system checks for is also what the HEIs put their resources on. As a consequence, one of the vice chancellors remarked that from the perspective of the national agency responsible for the EQA system, it can be a good idea to shift the EQA systems' focus once in a while because the institutions learn how to master and fill in templates and forms in order to be approved.

Finally, a critical remark on the time and resources put on EQA was that it risks taking so much from the HEIs' resources, "at the expense of other parts and [may] not at all work for enhancing the quality" (VC 1). 


\section{A Changed Higher Education Landscape}

As we can see, the different regions of the higher education landscape in Sweden, as analysed from the vice chancellors' statements, in many respects mirrors the historical exposé presented by Liedman (2009). The various and, to some extent, opposing layers representing different times in the transformation of Swedish higher education still seem to exist side by side among the vice chancellors. The traditional Humboldtian ideals of independently formulated problems for research and education are found in many of the described parts of the higher education landscape, despite their obvious challenge to parts more positive towards external cooperation, influence, and research funding. However, none of the presented regions are unknown to the vice chancellors - they are all features of the university's history and of official higher education policy. Thereby, they are also parts of the vice chancellors' assumptive worlds - that is:

a shared sense of what is appropriate in action, interaction and choice. That sense is inculcated through socialization in their distinct policy culture, and it always affects policy making. (Marshall et al. 1985, p. 90)

Bevir (2013) talks about traditions in a similar manner, as "a set of theories, narratives, and associated practices that people inherit and that then forms the background against which they hold beliefs and perform actions" (p. 50). The vice chancellors' assumptive worlds can, taken together, be said to compose the historical tradition and background of the different regions. With this shared sense or common tradition, it is less surprising that the vice chancellors, despite the somewhat opposing positions in the higher education landscape, could become united in their critique of the 2011-2014 national EQA system. Moreover, they successfully joined in a collective proposition to the government, which was also published in the public press. The new 2016 national EQA system displayed a great resemblance to the ASHEI proposition.

The part of the freedom and integrity region that identifies quality in higher education as the institution's capacity to refine the unique gifts that the students bring with them when entering the education represents aesthetic institutions. With the stress on close encounters and dialogue between teachers and students, the aesthetic institutions seemed to be the only ones that still could uphold the traditional ideals of an education that closely follows and encourages each student's development. None of the vice chancellors representing other HEIs expressed this view of quality in higher education. However, in the beginning of the1990s, the vice chancellors and heads of university administration still identified the dialogue among teachers and between teachers and students as "a necessary prerequisite for assuring and enhancing quality" (Bauer 1996, p. 78). So, in this respect, the vice chancellors' views of how to reach quality in higher education seem to have changed since the 1990s.

The more traditional ideas of the university, as represented by the first two regions of the higher education landscape - freedom and integrity and societal progress - both stress the importance of HEI autonomy and collegial influence in 
directing research and education. When the future of Swedish universities was debated recently in a seminar arranged by Uppsala University, the participating vice chancellors were critical of the lack of autonomy for Swedish universities and university colleges. A recent study by Karran et al. (2017), comparing autonomy for universities in European countries utilising 37 parameters, places Sweden very low on autonomy, at number 22 out of 28 countries. The ASHEI, the vice chancellors network, initiated a discussion on a long-term perspective on autonomy through a new report (Classon 2018). This issue might be the next area for the ASHEI and the vice chancellors' assumptive worlds to collectively play an important role in order to elaborate joint policies.

In Liedmans' (2009) historical exposé, the collegial organisation at the university was followed by a bureaucratic one and by a stress on leadership and on entrepreneurial progress. These layers can be compared with the two parts of the HE landscape representing regional benefit and the university as a state authority. The former implies that the new smaller university colleges need to be open to the interests of regional businesses to gain research funding. Hyvönen (2013) argues that they are embedded in an ideology of economic growth, in which:

commercialised research will lead to successful innovations. Innovations are good because they promote economic growth. Economic growth, in turn, secures welfare and general prosperity. Everybody wants that. Hence, everybody must work for greater economic growth. (Hyvönen 2013, p. 107)

The majority of public grants end up with the larger old universities, and the smaller university colleges increasingly have to rely on external grants from foundations, local authorities, county councils, and private companies, "funders that tend to make far reaching demands on what research should be prioritised and how it should be conducted" (Hyvönen 2013, p. 107). Problems at the regional and national levels are increasingly viewed as something for the HEIs to deal with, with the demands for solutions becoming part of the definition of quality in higher education. As Hasselberg et al. (2013) expressed it, "the notion of quality and demand merge" (p. 3).

Another of the newer regions of the HE landscape - the university as a state authority and, following this, the vice chancellor as an administrator of the university's capacity to live up to the national goals - can be related to the new professionalism and loss of discretion discussed by Hasselberg et al. (2013). As leaders of the HEIs, the vice chancellors are not expected to be led by professional values and ideals of good work. Instead, "professional judgement is replaced by rules, regulations, standards, management, etc." (Hasselberg et al. 2013, p. 140). As mentioned earlier, when interviewed, the vice chancellors seemed a bit unprepared for the wide questions about what characterises a university/university college and what quality in higher education is. This reaction might also be related to the vice chancellors' new role as administrators. When interviewed in the beginning of the 1990s (Bauer 1996), the vice chancellors and heads of administrations did not seem to have problems with the quality question, in contrast with the teachers at that time. 
After about 25 years in Sweden, the permanence and repetitiveness of national EQA systems, which Dahler-Larsen (2011) argues is one characteristic of evaluation machines, seems to have become an obvious part of the Swedish vice chancellors' duties and of their assumptive worlds. None of the vice chancellors maintained that the national EQA systems should be abolished. This can serve as a reminder of the Swedish history of it building its welfare state and the trust that was built among the citizens in relation to the state at the same time (see the chapter "Governing by Evaluation: Setting the Scene"; Larsson et al. 2012). The vice chancellors are part of this history, and their embodied knowledge (Freeman and Sturdy 2014) may hold traces of this trust, in turn legitimatising the national EQA systems, which are enacted with their cooperation at their HEIs and with other HEIs.

The governing potential of national EQA in higher education was notably visible when the 2011-2014 EQA system was in operation. The vice chancellors confirmed this in our interviews and in interviews to evaluate this reform performed by the Danish Centre for Studies in Research and Research Policy (Sørenssen and Mejlgaard 2014). In both interviews, the vice chancellors commented on the effects of adding extra efforts and resources to the independent degree project courses. This meant that the leadership at the university, faculty, and department levels had to gain insights into the state of these courses. The embodied knowledge of experienced teachers was requested and enacted in planning for improvements to and more resources for courses preparing students for the degree project. However, these redirections of resources also meant a potential loss of resources and quality in other courses.

The 2016 national EQA system, with its focus on the HEIs' internal quality assurance system, instead enforces the vice chancellors and the staff handling these systems, for them to get to know the different parts of their institution, enact this knowledge, and be able to describe their system to the SHEA.

\section{Finally}

Evaluation machines direct attention to certain criteria that "help determine what actors should strive to accomplish in a given activity" (Dahler-Larsen 2011, p. 206). As the vice chancellors testified, the 2011-2014 EQA system directed efforts and resources at the independent degree project courses, with a possible loss of quality in other courses. This illustrates what Dahler-Larsen (2012) has defined as constitutive effects.

In this chapter, we have described the Swedish higher education landscape as one with inherent contradictions, older traditional academic ideals coexisting with newer utility, or demand-based perspectives. In the next chapter, we will take a closer look at how these contradicting perspectives have played out in the political process leading up to the latest two national EQA systems. 


\section{References}

Agnafors, M. (Ed.) Universitetet AB. Om kommodifiering, marknad och akademi [The University Inc. about commodification, market and academy]. Göteborg: Daidalos AB.

Ahlbäck Öberg, S., Bennich-Björkman, L., Hermansson, J., Jarstad, A., Karlsson, C., \& Widmalm, S. (Eds.). (2016). Det hotade universitetet [The threatened university]. Stockholm: Dialogos Förlag.

Bauer, M. (1996). Quality as expressed in a Swedish reform of higher education and as viewed by university teachers and leadership. Tertiary Education and Management, 2(1), 76-85.

Bevir, M. (2011). Public administration as storytelling. Public Administration, 89(1), 183-195.

Bevir, M. (2013). A theory of governance. Berkely: University of California Press.

Classon, A. (2018). Några frågor om... akademins autonomi [Some questions about...the autonomy of the academy]. Stockholm: SUHF.

Cole, J. R. (2011). The great American University: Its rise to preeminence, its indispensable National Role, why it must be protected. New York: Public Affairs.

Dahler-Larsen, P. (2008). Kvalitetens beskaffenhed [The Constitution of Quality]. Odense: Syddansk Universitetsforlag.

Dahler-Larsen, P. (2011). The evaluation society. Stanford: Stanford University Press.

Dahler-Larsen, P. (2012). Constitutive effects as a social accomplishment: A qualitative study of the political in testing. Education Inquiry, 3(2), 171-186.

Elmgren, M., Forsberg, E. \& Geschwind, L. (2016). Special issue: Work and life in Academia. Nordic Journal of Studies in Educational Policy, 2.

Freeman, R., \& Sturdy, S. (2014). Knowledge in policy: Embodied, inscribed, enacted. Ort: Policy 883 Press.

Government Bill 1992/1993:1. Regeringens prop. 1992/1993:1. Universitet och högskolor - Frihet för kvalitet [Universities and university colleges - Freedom for quality].

Hasselberg, Y., Rider, S., \& Waluszewski. (2013). Introduction. In S. Rider, Y. Hasselberg, \& A. Waluszewski (Eds.), Transformations in research, higher education and the academic market. The breakdown of academic thought. Dordrecht: Springer.

Harvey, L., \& Green, D. (1993). Defining quality. Assessment \& Evaluation in Higher Education, $18(1), 9-34$.

Hyvönen, M. (2013). The foundation of knowledge according to the knowledge foundation. In S. Rider, Y. Hasselberg, \& A. Waluszewski (Eds.), Transformations in research, higher education and the academic market. The breakdown of academic thought. Dordrecht: Springer.

Jarvis, D. S. L. (2014). Regulating higher education: Quality assurance and neo-liberal managerialism in higher education-A critical introduction. Policy \& Society, 33(3), 155-166.

Karlsohn, T. (Ed.). (2016). Universitetets idé [In Swedish. The idea of the university]. Göteborg: Bokförlaget Daidalos AB.

Karran, T., Beiter, K., \& Appiagyei-Atua, K. (2017). Measuring academic freedom in Europe: A criterion referenced approach. Policy Reviews in Higher Education, 1(2), 209-239.

Larsson, B., Letell, M., \& Thörn, H. (Eds.). (2012). Transformations of the Swedish Welfare State. From social engineering to governance? Basingstoke/New York: Palgrave Macmillian.

Lewin, L. (2017). Ogiltig frånvaro. När universitetet förlorade sin frihet [Invalid absence. When the university lost its freedom]. Faun förlag 2017. ISBN 978-91-87435-92-8.

Liedman, S.-E. (2009). Tid för erfarenheter eller bara tid för yrkesförberedelse? Om universiteten och deras uppgift [Time for experience or just time for vocational preparation? On the university and its function]. Psykoanalytisk tidskrift. No 26-27, 7-35.

Ljunggren, C., \& Unemar Öst, I. (2008). Professional and personal responsibility in higher education. An inquiry from a standpoint of pragmatism and discourse theory. Utbildning \& Demokrati, 17(2), 13-50. Theme: Educating towards civic and professional responsibility.

Marshall, C. (1985). Policymakers' assumptive worlds: Informal structures in state education policy making. Paper presented at the annual meeting of the American Educational Research Association, Chicago, March 21-April 41985. 
Marshall, C., Mitchell, D. E., \& Wirt, F. (1985). Assumptive worlds of education policy makers. Peabody Journal of Education, 62(4), 90-115.

Olofsson, A. \& Hult, A. (2015). What is quality in higher education? Vice-chancellors' notions in times of accountability in Sweden. Paper presented in Abstract Book, NERA 4-6 March 2015: Marketisation and Differentiation in Education, 2015.

Olofsson, A., Hult A. \& Lindgren, J. (2015). The idea of a university in times of quality assurance The voices of Swedish vice chancellors. Paper presented at ECER 2015, 7-11 September, Hungary: Education and Transition - Contributions from Educational Research.

Rider, S., Hasselberg, Y., \& Waluszewski, A. (Eds.). (2013). Transformations in research, higher education and the academic market. The breakdown of academic thought. Dordrecht: Springer.

Segerholm, C., Rönnberg, L., Lindgren, J., Hult, A. \& Olofsson, A. (2014) Changing evaluation frameworks - Changing expectations? The case of Swedish higher education. Paper presented at the European Conference for Educational Research, Network 23, Symposium Governing by Expectations: School Inspection and Evaluation across Europe and Beyond, Part 1, Porto, 2-5 September, 2014.

SFS 1993:100. Högskoleförordning [The Higher Education Ordinance].

Sørenssen, M. P., \& Mejlgaard, N. (2014). Autonomi och kvalitet- ett uppföljningsprojekt om implementering och effekter av två högskolereformer $i$ Sverige. Delredovisning 2, Intervjuundersökning med rektorer. 2013/14: RFR22 [Autonomy and quality. A follow-up project about implementation and effects of two reforms in higher education in Sweden. Report 2, Interview study with vice chancellors]. Stockholm: Riksdagstryckeriet.

Swedish Higher Education Authority. (n.d.). Universities and university colleges. https://english. uka.se/facts-about-higher-education/higher-education-institutions-heis/universities-and-university-colleges.html. Accessed 8 Mar 2019.

Swedish National Agency for Higher Education. (2012). HSV (2012). Swedish National Agency for higher education: Review of ENQA membership. April 2012.

Wedlin, L., Pallas, J., Ahlbäck Öberg, S., Bomark, N., \& Edlund, P. (2017). Det ostyrda universitetet. Perspektiv på styrning, autonomi och reform av svenska lärosäten [The ungoverned university. Perspectives on governing, autonomy and reformed Swedish HEIs]. Göteborg: Makadam.

Open Access This chapter is licensed under the terms of the Creative Commons Attribution 4.0 International License (http://creativecommons.org/licenses/by/4.0/), which permits use, sharing, adaptation, distribution and reproduction in any medium or format, as long as you give appropriate credit to the original author(s) and the source, provide a link to the Creative Commons license and indicate if changes were made.

The images or other third party material in this chapter are included in the chapter's Creative Commons license, unless indicated otherwise in a credit line to the material. If material is not included in the chapter's Creative Commons license and your intended use is not permitted by statutory regulation or exceeds the permitted use, you will need to obtain permission directly from the copyright holder.

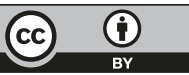




\title{
Hayek and the Red Tape: The Politics of Evaluation and Quality Assurance Reform - From Shortcut Governing to Policy Rerouting
}

\author{
Joakim Lindgren and Linda Rönnberg
}

\begin{abstract}
In this chapter, we draw attention to the important political dimension of the governing-evaluation-knowledge nexus. The aim is to describe and analyse the processes leading up to the two most recent national evaluation and quality assurance (EQA) systems in operation from 2011 to 2014 and from 2016 onwards by analysing the formation of the respective EQA systems and the actors involved in these processes. The chapter outlines political justifications and ideological beliefs and highlights central shifts and continuities in these processes. We explore how formation of EQA systems can be understood within a wider context of the work of governing by contrasting the fast, competitive "shortcut governing" from the 20112014 EQA system with the more dialogue- and consensus-oriented process implying a "policy rerouting" later, as manifested in the process leading up to the 2016 EQA system. We also discuss quality assurance expansion in the context of higher education policymaking.
\end{abstract}

\section{Introdu ction}

The chapter "National Evaluation Systems" concluded that Swedish national evaluation and quality assurance (EQA) systems have varied over time. In the following, we take a closer look at the political processes preceding the highly debated EQA system in operation from 2011 to 2014 and the most recent system implemented in 2016. ${ }^{1}$ The 2011-2014 national EQA system was highly debated and made its mark on both the 2016 EQA system and on the processes leading up to the decision to

\footnotetext{
${ }^{1}$ This chapter is partially based on previous conference presentations and papers that have been revised and updated (Lindgren and Rönnberg 2015; Rönnberg and Lindgren 2015). Some of the empirical data reported in this chapter have also been published in Lindgren and Rönnberg (2018).
}

\section{J. Lindgren $\cdot$ L. Rönnberg $(\bowtie)$}

Department of Applied Educational Science, Umeå University, Umeå, Sweden e-mail: joakim.lindgren@umu.se; linda.ronnberg@umu.se

C. Segerholm et al. (eds.), The Governing-Evaluation-Knowledge Nexus,

Evaluating Education: Normative Systems and Institutional Practices,

https://doi.org/10.1007/978-3-030-21143-1_5 
introduce this new system. As we zoom in on processes of policy formation, it will become clear that EQA systems do not just replace one another like the seasons of the year - shifts may involve deep and heated political conflicts. This chapter will draw attention to how EQA systems are framed by different ideological beliefs that are manifested in designs in terms of whether such systems ought to, for instance, focus on conditions, processes, and/or results. We thus want to highlight the important political dimension of the governing-evaluation-knowledge nexus. As Jarvis has observed, "Far from simply a managerial tool, the history of quality assurance has been inextricably political; used as much to engineer sector and organizational change associated with specific political agendas as it has the pursuit of excellence" (Jarvis 2014, p. 158).

We ask the following questions:

- What political justifications and framings characterise the reform processes leading up to the respective EQA systems, and what actors were involved?

- What continuities and/or shifts can be discerned in the respective debates?

- How can these political debates be related to governing by evaluation?

The rest of this chapter has the following structure: We begin by discussing our approach and present the data analysed in the chapter as a way to set the scene. The policy story we intend to tell begins with an analysis of the process leading up to the 2011-2014 EQA system and the actors involved in this highly debated process. We then briefly move on to the system that was put into effect as a result of the reform and point to the incremental readjustments that were implemented. We go on to discuss the process leading up to the 2016 EQA system and highlight the overall bottom-up and consensus-oriented model of policymaking characterising this policy process. The concluding discussion points to the ideological framing of quality assurance, issues of policy speed, and how national EQA seems to expand over time.

\section{Approaching the Politics of Evaluation in Higher Education}

The starting point for this book is the inherent political-ideological character of the governing-evaluation-knowledge nexus. Evaluation is an increasingly important activity in society as a whole, and as such, it is also embedded within a political frame and governing rationale (Dahler-Larsen 2011). As we noted in earlier chapters, a dimension often referred to in governance concerns centralism and decentralism. This dimension is, of course, also related to and embedded in particular national political histories and debates. The Swedish Social Democratic Party has made a distinctive mark on Swedish education policy. In the post-war era, this party has rarely been out of office. Parties located to the centre-right formed coalition governments in the mid-1970s, in the early 1990s (1991-1994), and for two consecutive terms in the 2000s (2006-2014) (Jarl and Rönnberg 2019). The processes we analyse in this chapter thus began during the non-socialist government's first term in 
office in 2006 and spanned the post-2014 national election developments, when the social democrats formed a minority government with the Green Party (Aylott and Bolin 2015).

Going back to the centralisation-decentralisation divide, social democracy has historically turned to centralism, the "strong state" (Lindvall and Rothstein 2006), and regulation as means to realise political goals, while the political right has emphasised decentralism and deregulation (Bennich-Björkman 2002). During the last decades, however, this polarisation has largely been dissolved as ideas on decentralisation, deregulation, and marketization have been embraced across the political spectrum from left to right, contributing to political-ideological convergence.

Swedish higher education policy may not be the most politicised policy area within the Swedish welfare state, compared to, for instance, compulsory education or employment. Even so, there are important ideological lines of conflict within political debates concerning higher education governance and evaluation. Tangent to the more general political debate, there are converging ideological and partypolitical unifying standpoints in terms of common overall goals regarding, for instance, academic freedom, collegiality, and autonomy. However, when looking more closely at the political rationale on how these common and cherished values are to be promoted and defended, certain political and ideological differences are brought forward. We argue that one way to unveil and explore such lines of potential conflict is to analyse political debates of external evaluation systems and their designs.

To explore matters of evaluation design, a general definition is a good starting point. Notably, conceptualisations of and in social science are seldom straightforward, and in our case, there exist numerous definitions of evaluation. We will not enter that discussion here, but instead turn to Vedung, who has provided a general definition on this flexible concept, namely that:

Evaluation is a careful retrospective assessment of the merit, worth and value of administration, output and outcome of government intervention, which is intended to play a role in future practical situations. (Vedung 2000, p. 3)

Evaluation may focus on different aspects of an intervention, such as a higher education programme or institution, for instance:

- (Pre)-conditions/input (e.g. funds, people, instructions)

- Processes (e.g. teaching, supervision)

- Outcomes/results (e.g. what the students have learned; goal attainment, examination results, assessments of student final degree projects, etc.)

If the overall purpose is to use the evaluation for further and future improvement of the intervention, a holistic approach to evaluation intuitively appears valid. In order to understand how a certain result has come about, one must examine the conditions and process. It is not sufficient to only to look at the results and/or outcomes of the intervention; one must establish how these results came about (Weiss 1998; Franke-Wikberg 1992). Where to put the emphasis and what approach to 
employ in the assessment of (certain aspects of) interventions have differed. Different actors located in different parts and functions of the state, such as political parties, national agencies, HEI chancellors, researchers, etc., have displayed different opinions and preferences in this regard. Additionally, as the organisation and design of national EQA systems are ultimately and intrinsically related to state governance, they have been the objects of debate emanating from certain politicalhistorical developments.

\section{Governing Evaluation: Governing Knowledge in Swedish Higher Education}

Early forms of evaluation were introduced as a part of the Swedish "rational social engineering" welfare state project originating in the 1940s (Vedung 1998; Gröjer 2004). At that time, the expansion of the HE sector served political goals pursued by the Social Democratic Party in terms of social and regional justice and equality. During the 1950s, however, problems of low examination frequencies in higher education were identified, and these problems did not go away despite an increase in input by way of raising the number of lecturers and lecturing hours (Abdallah 2002). In the 1960s, more elaborate pedagogical theories (e.g. frame factor theory; Dahllöf 1999) attempted to "open the black box" of the education process and explain the relative failures of the expansion of the education system in overcoming problems of social inequality (Abdallah 2002). These ideas were later fused into an evaluation model that included conditions, processes, and results (Franke-Wikberg 1992). As we showed in the chapter "National Evaluation Systems", national EQA systems in Sweden have evolved since the 1990s, and these ideas have continued to circulate and been put to use (albeit with a somewhat different emphasis) in components of different EQA systems. In this chapter, we will show that the 2011-2014 EQA and 2016 EQA systems are no exceptions.

While such comprehensive systems that seek to asses conditions, processes, and results are perceived as scientifically valid, they are also costly and have often been criticised for being too bureaucratic and inefficient (Gröjer 2004). As we will see in the following, proponents of the political right have tended to argue that thorough assessments of conditions and processes run the risk of interfering with the autonomy and inner workings of HEIs (cf. Government Bill 2009/2010:139). Inherent in this criticism is a rather overlooked aspect of problems with governing by evaluation. We express this as the problem of governing situated knowledge. The basic idea is that attempts to assess processes of knowledge production or teaching with the overall purpose of improvement and/or control in fact run the risk of eroding important aspects of such practices.

This critique of technological rationalism and defence of situated knowledge can be discussed in line with arguments from Hayek on "the role of knowledge in society" (Hayek 1945). Hayek argued that top-down planning runs up against a 
"knowledge problem" that makes comprehensive, overall management of complex, dynamic systems inherently infeasible. According to Hayek:

[T]hose who clamour for 'conscious direction' - and who cannot believe that anything which has evolved without design (and even without our understanding it) should remember this: The problem is precisely how to extend the span of our utilization of resources beyond the span of control of any one mind; and, therefore, how to dispense with the need of conscious control and how to provide inducements which will make the individuals do the desirable things without anyone having to tell them what to do. (Hayek 1945, p. 527)

Hayek's argument holds implications for any attempt to govern human practices since the knowledge necessary for efficient resource allocation is "dispersed, subjectively held, fleeting, and largely tacit" (Foss and Klein 2013, p. 2). In this way, questions of governing by evaluation are not just a matter of the cost of:

searching for, identifying, transmitting, etc. such knowledge and/or setting up complex mechanisms for its revelation; like Polanyi (1959), Hayek seems to have held the view that there is knowledge that is inherently personal and cannot be communicated at any cost. (Foss and Klein 2013, p. 13)

Therefore, while knowledge ultimately resides in the heads of individuals, Hayek (1945) claimed that when such knowledge is somehow combined and allowed to evolve over time as dynamic and spontaneous systems, humans will possess knowledge that they do not develop if separated. Nevertheless - and this is important in relation to systems of EQA - nobody possesses all this knowledge in its totality; hence it cannot be codified and then collected and held by any central planner. Thus, it is argued, evaluation ought not focus on or interfere with the process (i.e. the actual work within HEIs) - this must be left to "the man on the spot" (Hayek 1945, p. 524), and evaluation ought only to assess the outcome of the process.

In this chapter, we highlight how these ideas on governing evaluation are played out in Swedish higher education policymaking; we explore the role of knowledge in political justifications and framings as well as continuities and/or shifts in the contemporary debates on EQA systems. We also link our exploration to issues of deliberation and speed in the processes of political policymaking.

\section{Modes of Policymaking: Issues of Deliberation and Speed}

Evaluation systems may be organised as a top-down or bottom-up activity or try to combine these approaches in different ways (Franke-Wikberg 1992). The EQA systems, the processes of designing them, and the policymaking leading up to their instigation can be conducted in several ways. In this context, we want to draw attention to processes of policymaking in terms of deliberation and speed. Lewin (2002) argues that political decision-making can be conceived in the following two simplified and ideal typical ways: firstly, in the form of a consensus-oriented policymaking approach, in which parties, decision makers, and other stakeholders try to agree as much as possible. Secondly, and in contrast, policymaking can also be 
characterised by a competitive approach. In this mode of policymaking, the winning political party or parties show its/their ability to take action and not let policies be watered down to reach a broad consensus. The focus is rather on prioritising the task of getting reforms and new regulation in operation.

On one hand, decisions made according to the cooperative model are more likely to be long-lasting and not to be withdrawn if a new government comes into office. On the other hand, cooperation and seeking consensus also entails some difficulties when it comes to (certain perceptions of) political accountability. Arguments have been raised that the competitive model can indeed be seen as more efficient and can result in more innovative policy solutions (Lewin 2002). Far-reaching cooperation and consensus-seeking across the political spectrum and among stakeholders run the potential risk of producing "more of the same" instead of something "new" due to the nature of reaching agreement and bargaining, often resulting in small, incremental adjustments (Lewin 2002).

More recent discussions on modes of policymaking and their speed have drawn attention to the increasingly trans- and international character of such developments. This is highly relevant for higher education, as Europeanisation and influences of international organisations, such as the European Association for Quality Assurance in Higher Education (ENQA), are prominent in this particular policy field. Peck and Theodore (2015) argue that:

The modern policymaking process may still be focused on centers of political authority, but networks of policy advocacy and activism now exhibit a precociously transnational reach; policy decisions made in one jurisdiction increasingly echo and influence those made elsewhere; and global policy "models" often exert normative power across significant distances. (Peck and Theodore 2015, p. 3)

This work is informed by Jessop's ideas on fast policy, i.e. a form of policymaking "reflected in the shortening of policy-development cycles, fast-tracking decisionmaking, rapid programme rollout (...) and relentless revision of guidelines and benchmarks" (Jessop 2015, p. 208). An overall starting point is that policymakers increasingly face temporal pressures to design and implement policy due to general acceleration of time and shortenings of time horizons in other social spheres of society (Rosa 2013). Policymaking, it is argued, thus becomes increasingly "based on unreliable information, insufficient consultation, [and] lack of participation", often framed by "the rhetoric of crisis" or "a climate for emergency measures or exceptional rule" (Jessop 2015: 208). According to Jessop (2015), these conditions tend to privilege policy actors who are able to "operate within compressed time scales, narrows the range of participants in the policy process, and limits the scope for deliberation, consultation, and negotiation" (p. 208; cf. Takayama et al. 2017).

We use these ideas on modes and speed in policymaking as an overall analytical framework to discern the policymaking styles and rationales that our analysis of the two national EQA policy processes brings to the foreground, bearing in mind the identified governing evaluation - governing knowledge issues raised in the above discussion. 


\section{Data and Sources}

In this chapter, we primarily draw on official and political documents, including government bills, reports, and parliamentary debates but also on different documents produced by various stakeholders and actors in these processes. We see these documents as embodying "the political processes by which they are produced" (Freeman and Maybin 2011, pp. 164-165). Following this, we have analysed and collected materials produced at different stages in these political processes leading up to the two most recent EQA systems. This material also includes reports from the Swedish National Agency of Higher Education (SNAHE, in Swedish Högskoleverket) and from 2013, the Swedish Higher Education Authority (SHEA, in Swedish Universitetskanslersämbetet). Reports from other stakeholder associations, for instance, the vice chancellors' organisation, the Association of Swedish Higher Education (ASHEI, in Swedish SUHF), the university teacher union SULF, and the student association SFS, are included. The process and the resulting national EQA system have been exposed in several media outlets and form a background for our understanding of the debates. We also draw on data from interviews with a number of actors involved in these processes. In particular, we turn to the project's interviews with policy brokers (PB), including individuals who were actively involved in these processes.

We did a qualitative-directed content analysis (Hsieh and Shannon 2005) of the text and transcripts in which we initially identified relevant passages of text and then examined these passages in more detail by paying special attention to the arguments, justifications, and attempts of legitimation embedded in the processes leading up to the respective EQA systems. We finally add that we do not intend to elaborate on all details in these processes but rather to highlight some important and signifying traits and moments.

\section{The Process Leading up to the 2011-2014 EQA System: Shortcut Governing}

Through a government decision in 2008, the evaluation system for 2007-2012 was cancelled due to heavy criticism from the higher education sector. The argument was, briefly put, that there was too much focus on conditions and too little on processes and outcomes. One of our informants, a key actor involved in the design of the system that was supposed to replace the revoked system, recalls the overall critique and debate and that the Director General at the SNAHE used to banter about the bureaucratic meticulousness of the 2007-2012 system: "It was all about counting the number of senior lecturers", but "what these lecturers were actually doing if they were teaching at all - was not checked" (PB 7). Critics argued that the system was not transparent and thus became out of touch with reality, and it demanded that HEIs fill in "tidy Excel sheets that required information "not of this world" (PB 7). 


\section{Preparing a New EQA System}

In 2009, the Ministry of Education formed a group led by a university vice chancellor that included representatives from the SNAHE, ASHEI, and the main student union. This group delivered a report with suggestions on how to design a new national EQA system. According to another of our informants, who had been working within the SNAHE as an architect of the 2007-2012 system, the ASHEI slowly became a "power broker" within the HEI sector during this time:

Initially, [ASHEI] was an interest group without any formal status. It was a small club for the vice chancellors where they met and discussed common affairs and where they exchanged experiences, but during this time ASHEI developed into a very potent powerbroker. There were many reasons for this (...) The new [SNAHE] Director General, for example, did not understand that he did no longer belong to the circuit around ASHEI, where he had been an influential person. (PB 2)

This informant described a cultural shift in which boundaries between the jurisdictions and functions of assessors and those assessed were blurred:

You cannot let those who are to be assessed set the conditions for the assessment, but of course, there must be dialogue and mutual understanding. There must be mutual respect among the parties and for the different functions of those parties. (PB 2)

At this point, new forms of interchange between actors within the agency and HEIs were initiated. According to Policy broker 7, this was a strategically important transformation:

\footnotetext{
It was a cultural clash, because N.N. and N.N. [authors' remark: names omitted] and many of their disciples shared the conviction that the agency must not involve the sector too much when designing a system. (...) We had the idea that when you design a new system, you darn [well] must involve the sector a lot, you must build it with the sector (...) [and for] these systems to work, you must work together with the sector and design the systems so that the people within academia find them relevant. It was a pity that, in a sense, we did not get the chance to develop our system further, because it was [an open] window that I think will never be open again. (PB 7)
}

As we will see later in this chapter, this window of dialogue was soon slammed, but eventually it was opened again as ideas on trust, cooperation, and engagement were reintroduced.

\section{A Rejected Agency Proposal Caused a Stir}

As mentioned, the Ministry of Education gave an assignment to the SNAHE in 2009. The agency was to develop a design for a new EQA system to include socalled quality evaluations that would highlight and measure results. Weekly meetings were held with the ministry and agency, and the SUHF and SFS were also partners in the discussions. About 6 months later, the work resulted in a report to the ministry emphasising three aspects in particular: expected learning outcomes and 
examination, achieved learning outcomes, and students' experiences and influence (SNAHE 2009). According to Policy broker 7, it was a pared-down system that deliberately broke with the previous system. It was deliberately "very, very slimmed". According to this informant, there is a risk for evaluative systems to expand if experts are allowed to design them. We can see that discussions on evaluation design are not only about the individual parts of systems but about the size and scope of systems:

You cannot let those "quality people" draw up [these systems], because it's like in every other area of expertise: They want to do everything. The previous system was enormous. I think that it included five components; it was way too bulky. (PB 7)

The ministry then worked on a government bill (2009/2010:139) that was to be presented to parliament. As this work progressed, it became clear that the Ministry was not completely satisfied with the SNAHE report and wanted to make further elaborations and amendments. The Ministry, however, did not involve the SNAHE in these further discussions, and the SNAHE report was turned down. It was accused of not focusing enough on outcomes and thus did not respond to the terms of reference the working group had received.

According to Policy broker 3, who at the time was a key political actor within the centre-right government, the argument for turning down the report was based on a basic "ideological view" of autonomy that was congruent with a particular evaluation design. In the words of Policy broker 3:

It [the Ministry's argument, authors' remark] was based on an insight that HEIs have been micromanaged in many ways. (...) So, the idea was to decrease micromanagement based on the insight that it is not efficient. It is not efficient to seek to govern complicated activities like higher education and research through micromanaged organisations (...) The debate was greatly about [whether] "it [is] right to have a system that concentrates on the results of activities" or a system where evaluation is about [determining whether] "the processes [are] found to be good". I think the latter option is wrong since you end up inside the activities fiddling around with how things are done instead of looking at the results. (PB 3)

One expression of this ideological conviction was the attitude towards the planned use of "learning outcomes" within the evaluation design in the rejected SNAHE report. Policy broker 7 asserted that these "learning outcomes and the assessment of whether these outcomes were attained became the 'hate object' [authors' remark: a strong Swedish word to indicate what attracts discontent] of the ministry and a reason for why the report was turned down" (PB 7).

Eventually, the Ministry of Education presented their version of a new EQA system. This was done with the bill "Focus on knowledge - quality in higher education" (Government Bill 2009/2010:139). Before this bill was submitted to the parliament, actors such as the ASHEI and the SNAHE had tried to argue in favour of the old rejected report, which was claimed to have been largely endorsed and approved by the HEI sector, in contrast to the hastily prepared bill (cf. Kaliber 2013). In the bill, the government stated that the system delivered in the SNAHE report was not in line with the government's ideas on autonomy, as it focused too much on expected learning outcomes in curricula and forms of examinations, i.e. 
issues related to planning and realisation of teaching and learning activities. It was concluded that:

Experiences from previous evaluation systems show that evaluations are powerful instruments of governance. Grounds of judgement that target how the internal processes are designed in order to reach the goals risk producing unintended steering effects, hence such grounds of judgement ought not to be part of the national evaluation system (...) The assessment ought to primarily concern actual education results and not be based on documents that merely display the intentions of a HEI when it comes to carrying out education with good results. (Government Bill 2009/2010:139, p. 13)

\section{A Heated Political Debate}

In June 2010, a parliamentary debate was held (Parliament Minutes 2010). The political opposition argued against both the design of the system and the "shortcut" policy process behind it. The new proposed national EQA system was criticised for its narrow focus on results and for being micromanaged by the political (Government Ministry) level and thereby not allowing HEIs sufficient autonomy. In the debate, the social democrat Mikael Damberg, who represented the political opposition, summarised the critique. He said:

\footnotetext{
The government has - on its own and totally unprovoked - bulldozed over the entire higher education sector and in addition, on its own - as it has been said - "played around as if they were a national agency for higher education" by knocking together a homemade micromanaged quality evaluation system. This is unbelievable. Because the preconditions have never been better than they are today: There is a deafening unity in the Swedish Parliament [concerning a need for a new system]. (...) This should have been done in close cooperation with the HEIs, ASHEI, and the students. But when the work was done and anchored, the government jumped in like an elephant in a glass shop and messed around. They came up with a new system that was presented through a couple of slides in an oral presentation at a meeting with the HE sector just 20 days before the bill was sent to the parliament. (Parliament Minutes 2010, Mikael Damberg, Social Democratic Party)
}

The quotation points to a critique aimed at the democratic process itself. Thus, accusations of micromanagement that the centre-right wing directed to system designs under social democratic rule (including input, process, and results) are now directed at how such systems are politically processed and decided (top-down without deliberation). Minister for Higher Education and Research Tobias Krantz replied in the debate and underscored that the nature of the political process and policymaking is in fact about conflicting perspectives and eventually also about determination and the ability to act in times of urgency:

The government bill has caused debate. This is excellent. It is good that important bills are debated and that they excite people. If the Swedish higher education sector was quiet we would have a reason to be worried. There are voices in favour of the bill, and there are others against it. The best way to avoid criticism is to do nothing. However, Sweden is facing a very important and big challenge. This is not the time to sit with our arms crossed. Sweden shall have a world-class higher education. (Parliament Minutes 2010, Tobias Krantz, Liberal Party) 
Policy broker 7 also underlined the virtues of a decisive and efficient mode of policymaking in that even though deliberation is crucial, fast policy is needed to produce change. This informant argued in favour of line management and against traditional collegiality as a solution to this problem:

If the ambition is to be at the front of the development in an international perspective, then HEIs cannot only be managed collegially, because not much change will come about. (...) We were convinced that we [actually] needed something [other] than what we had. (PB 7)

The discussions above about the political process leading up to the 2011-2014 EQA system reveal different ideological approaches to HE governance and evaluation of HEIs. These ideas are closely related to essential overall goals of and in higher education, such as academic freedom and social and economic development. These ideas were fused into and manifested in concepts such as autonomy and collegiality and also, as we have seen, different designs of EQA systems. At the end of the day, however, actors across the political spectrum appeared to be willing to govern HEIs through evaluation with somewhat different technologies.

\section{Implementing the Debated EAQ System}

Somewhat paradoxically, and in contrast to the government rhetoric, a parliamentappointed evaluation carried out by a group of Danish evaluators showed that the results of the 2011-2014 EQA system did seem to govern internal processes within HEIs in profound ways (Sørensen et al. 2015). The increasing orientation of actors within HEIs towards expected learning outcomes implied a thorough implementation of the Bologna reform. This was manifested through careful planning, assessment, and documentation, which was put forward as one of the most important success factors in this EQA system (Sørensen et al. 2015, cf. SHEA 2015, 2017). In a likewise paradoxical manner, the 2011-2014 system had a centralising effect and produced a continuous expansion of quality assurance work. One vice chancellor who was interviewed in the evaluation described the changes imposed by the EQA system in the following way:

Previously, we were incredibly decentralised, and in principle, all quality work was managed locally in the organisation. But we have centralised it, because it was needed (...) This evaluation model was very non-transparent to many actors within the organisation (...) After the first round [of evaluations] we could see that this was not going to work, so what we did was to set up a central... firstly, a central support function, but also, really, an organisation where the areas, that is our faculties, have their organisational representatives involved who can support and assist. (vice chancellor in Sørensen and Mejlgaard 2014, p. 22)

This tendency towards expansion and centralisation will be further elaborated in this chapter and later in this volume. Now we turn to the process initiated during the implementation of the 2011-2014 system that resulted in the 2016 EQA system. 


\section{The Process Leading up to 2016 EQA System: Policy Rerouting}

In the following, we will show that how EQA systems were politically "done" changed as ideas on dialogue and mutuality gained ground as a response to the previous perceived shortcut process. This dialogue was embedded within a discursive frame that, at least on the surface, appeared to slow down the speed of policy. As we shall see, deliberation and dialogue involve time-consuming work by actors. In addition, ambitious evaluation designs that result from the cooperation and consensus-seeking process may in turn produce new undertakings within organisations as national EQA expand. Slow policy may thus become a functional condition for social acceleration (Rosa 2013).

In April 2014, just a few months after the Swedish agency lost its membership in the ENQA, SHEA University Chancellor Harriet Wallberg was commissioned to propose a new quality assurance system for the higher education sector by the same Government that did the shortcut and introduced the 2011-2014 EQA system. This meant rerouting the process and the EQA system. Looking at the process, concepts like mutual trust, collaboration, and dialogue were emphasised, and the work was done in collaboration with different reference groups, including HEI, student, agency, and working-life (including unions) representatives. This involved efforts and work from several actors. There were meetings with HEI representatives; minutes were written and stored at the ministry (Ministry of Education 2015), and a consensus-oriented approach was stressed (cf. SHEA 2014a). Of course, such meetings and procedures had been taking place in the previous process leading up to the 2011-2014 EQA system as well, but as we will exemplify, the narrative to be conveyed in the new process was to explicitly declare the importance of coordination, cooperation, and seeking dialogue. In this context, trust comes across as a central notion in this discursive construction of values and meanings.

\section{Trust of and in Swedish Higher Education and Beyond}

In our interviews, many key policy brokers expressed hopes for the future and that such deliberations would result in a system based on trust:

The big differences between EQA systems are between systems that trust HEIs and systems that do not trust HEIs. Sweden has had a system that did not have any trust in the HEIs. We have had that for many, many years in different forms. I hope that we are moving onto a system that puts trust in the HEIs. (...) Ultimately, the political level must decide if it can put trust in the hands of the higher education sector. (PB 4)

As demonstrated in the chapter "Europe in Sweden", policy brokers also adopt and circulate ideas on national and international arenas, carrying knowledge from international to national discussions. One of our informants who was involved in such international collaborations and exchanges compared the European 
development with the situation in Sweden. This policy broker highlighted an encounter with EQA systems within a wider European meeting and setting also relating to the issue of trust:

You could feel, not just the systems on paper, but people of flesh and blood, talk about their
experiences. One important conclusion that we brought [home] with us was that the
Swedish culture on [the] evaluation of higher education specifically, and perhaps more
generally, is characterised by far less trust than what we could see in these countries (...)
the autonomy of HEIs had a completely different and profound meaning abroad. People
within the HEIs took on the responsibility, and within the equivalent to SHEA and the
Ministry of Education, there was respect and trust in that HEIs actually took on this respon-
sibility. So right now, we are hoping that all the work with the proposal [the forthcoming
2016 EQA system, authors' remark] (...) will lead not only to a new improved EQA system
but [will] promote a certain an academic culture in Sweden. (PB 1)

This quotation is also significant in that it highlights that Europe (and the ENQA) became a more dominant point of reference in the preparatory work in this policy process compared to the 2011-2014 process. Importantly enough, the SHEA Director General was quoted on the SHEA English website: "When implementing the new system for quality assurance for Swedish Higher Education, the European Standards and Guidelines must be taken into account" (SHEA 2014b) - thereby strongly conveying the message to the English-speaking SHEA website readers that Sweden and the agency are committed to ensuring that the new EQA system will meet international and European standards. It can be noted that the same text was also published on the ENQA website under the "News" section (ENQA 2014).

Later, on the Swedish SHEA website, the Head of the Department of Quality Assurance at SHEA described the process:

It was important for us to invite a dialogue before we have a complete decision basis. Also [the HEIs, authors' remark] will be using the new system, since it is important they are involved (...) After having discussed the proposal for a new national quality system with over 400 people, we are bound to say that the response has been largely positive (...) We have received important input (...) both before we took the final decision and before the pilots that are starting this autumn (...) Most important is perhaps that we felt that there was trust [authors' remark: among people in the higher education-sector] in the new quality assurance system. (SHEA 2016)

\section{Shifts and Continuities in Governing (by) Evaluation?}

In contrast to the former process, the 2016 EQA system proposal was not only deliberated as it was developed and designed; it was also formally sent to stakeholders for referral. In the 2016 EQA process, the SHEA was assigned responsibility for further elaborating on how to design the 2016 EQA system (Ministry of Education 2015). In contrast to the previous process, the SHEA was thereby granted an important role as an expert agency in the process of designing and implementing the 2016 EQA system. The rerouting thus not only targeted the process but also the content and activities in the EQA system. This rerouting may result in a different mode of 
governing by evaluation, and in the forthcoming chapters in this volume, we will address this potential shift in more empirical detail. In certain ways, and on the basis of the data presented in this chapter, it is possible to conclude that the new EQA system implied a form of shift even before its implementation. This shift refers to the values used to frame the processes leading up to the respective EQA systems as "shortcut governing" to be "rerouted". In addition, the 2016 EQA system implied some partial continuities as well as changes - both of which were embedded within the common discursive framework of trust and mutuality. The 2016 EQA system would not primarily be an assessment of students' independent projects (final degree projects), indicating a break with the former 2011-2014 EQA system. A much highlighted "new" (but essentially recycled; see chapter "National Evaluation Systems") dimension of the 2016 EQA system was the SHEA assessment of HEIs' internal quality assurance work. But some activities from the former EQA systems remained, even if reformed - for instance, thematic evaluations and evaluations of education courses and programmes (SHEA 2014a). Such shifts and continuities in processes and EQA systems also inform our concluding discussion.

\section{The Politics of Evaluation and Quality Assurance Reform}

In this chapter, we have described and analysed the processes leading up to the two most recent national EQA systems in operation from 2010 to 2014 and from 2016 and onwards. There have been heated political and ideological debates at times, particularly during the first period, inflicted by personal interests and conflicts, involving both high-level official resignations and public disputes (cf. Kaliber 2013).

\section{It Is Natural to Measure and Assure Quality in Higher Education}

Despite turbulence and change, a fundamental and important continuity characterises both periods and systems. For example, no substantial public objection or struggle existed about the actual need for the state, via its agencies, to (continue to) evaluate, assure, measure, and steer HEIs. Hence, there is a strong cross-party consensus about the need for such policies and activities in both processes. A Social Democratic MP summarised the common and widespread political assumption about the need for external evaluation in the following statement from the 2010 parliamentary debate:

It is natural to measure and assure quality in higher education. The state finances higher education and needs to know if tax money is used the best way possible (...) Students have a right to know the quality of the education they are attending (...) [and] they also have the right to know how useful their education is on the labour market. (Parliament Minutes 2010) 
Nevertheless, as we have seen, the ideological framing of autonomy and/or trust, academic freedom, etc. has been quite different within the two modes of policymaking in the analysed processes. In this way, the chapter has shown that stakeholders represent issues related to the politics of evaluation and quality assurance reform in partly different and conflicting ways within and across the two decision-making processes. As was also made evident, these problematisations are all directed towards justifying how to design the (perceived best) external national evaluation system. In this way, the inherent taken-for-grantedness that a desire indeed exists for such a system to be implemented in the first place goes largely unaddressed.

The act of extensive national external assessment of and in HEIs is not only taken for granted but also naturalised as a taken-for-granted part of the mindset of each actor and stakeholder in the sector. To illustrate this far-reaching striving for enhancement (cf. Saunders 2014; Stensaker 2007), a Social Democratic MP made a public and almost religious pledge to all higher education stakeholders, arguing that quality development is an approach to life: "Every morning when you wake up, you shall repeat a mantra about how you can work with continuous quality improvement" (Parliament Minutes 2016).

Yet, even if all political actors subscribe to traditional academic values, they also - albeit with different ideological underpinnings - to some extent show conflicting ideas on evaluation designs. Still, they unanimously push for quality assurance reform as well as to the need to measure. These simultaneous and somewhat contradictory stances are not easily aligned. As noted by Jarvis (2014), HEIs are caught between two "narratives" that appear to be difficult to interweave:

The university sits oddly amid two narratives; one that prizes academic freedom, independence of thought and expression, heterodoxy and exploration to create new knowledge frontiers, on the other hand, an increasingly intrusive series of regulatory regimes that seek to manage, steer and control the sector in ways that serve the interests of the state and the economy by applying specific ideational motifs about efficiency, value, performance, and thus the economic worth of the university to the economy. (Jarvis 2014, p. 156)

A more easily managed interlinkage is that the new government used the shortcut policymaking narrative politically to justify the rerouting of the latter process. In the process leading up to the 2011-2014 EQA system, academic freedom was framed as a value that is protected and defended, whereas the system was designed to only assess the outcomes, in the debated assessment of students' degree projects. This EQA system was said not to assess and thereby interfere with the (HEI internal) processes and preconditions leading up to the educational outcomes (Government Bill 2009/2010:139; cf. Parliament Standing Committee on Education 2010). However, when looking at the implementation, this EQA system did not produce a tangible rise in HEI autonomy, and evaluations have pointed to the further centralisation of quality assurance work within the HEIs (Sørensen et al. 2015). This EQA framework produced a more thorough implementation and enforcement of international and national rules and policies as well as a common set of learning outcomes that became a cohesive and obligatory reference for planning, teaching, and examination in HEIs. In this sense, it appears to have implied less autonomy, rather than the opposite (see also Toots and Kalev 2016). 
We wanted to place the political processes leading up to the national 2011-2014 and the 2016 EQA systems in the limelight. In this chapter, we sought to show the attempted framings by the actors involved and concluded that a shortcut and fastpaced (Jessop 2015) policy style was replaced by a more consensus- and dialogueoriented approach in the latter process (cf. Lewin 2002). In this vein, a relocation of the framing of and within the political discourses leading up to the 2016 EQA system also seemed to occur. We claim that certain non-government organisations, such as the nationally powerful ASHEI and, later on, the ENQA, came to set important and distinctive marks on the policy processes and contributed to the shift that ultimately came to position the 2016 EQA system in a discursively different way.

\section{Expansion and Complexity when Governing Situated Knowledge}

Significant in this development is also that the expansion of EQA-ambitions was done by bringing the HEI actors back in, by offering deliberations and giving HEI representatives a place at the drawing board. Such involvement did not result in less evaluation or auditing. Somewhat paradoxically, the HEI deliberations in the second process did not "roll back" state attempts of governing by evaluation. Rather, the earlier observation by one of our interviewed key policy actors draws attention to a plausible explanation: if the so-called quality people, i.e. those with expertise in quality assurance and evaluation, are involved in constructing evaluation systems, "they want to do everything" (PB 7). Thus, this chapter has illustrated the ongoing expansion and the complexity of quality assurance - as well as the importance of "expertise" and thereby of knowledge of and within these processes. Moreover, we have shown how the emerging cadre of professionals that we refer to as "qualocrats" mobilised themselves as power brokers by tearing down the previous boundaries between the subjects and objects of evaluation. This observation is also helpful to understand issues of resistance, more precisely the lack of critical debate concerning national EQA systems. This is a topic that we will return to later in the book.

We find that the analysed Swedish higher education case illustrates how "slow policy", in the form of dialogue and deliberation, is contributing to increased complexity and becoming a functional condition for social acceleration (Rosa 2013). In the beginning of this chapter, we also discussed the wicked problem of governing situated knowledge and turned to Hayek (1945) for illustrations of the risk that externally assessing processes of locally held and embodied knowledge production or acquisition will erode important aspects of such practices. Even if the data analysed in this chapter cannot provide a clear-cut answer on handling this problem, the data indeed point to the political attempts and politically articulated will to (a) assess and thereby (b) govern such processes, albeit by different means and technologies. Such manifestations are the different modes of policymaking and the associated paces for the work of doing governing they entail. Overall, however, we suggest that ideas and reforms on autonomy launched by the centre-right government did not manage to unfetter higher education actors from external accountabil- 
ity pressures. On the contrary, these policy attempts appear to provide an example of what Graeber (2015) terms "the Iron Law of Liberalism", which states that:

any market reform, any government initiative intended to reduce red tape and promote market forces will have the ultimate effect of increasing the number of regulations, the total amount of paperwork, and the total number of bureaucrats the government employs. (Graeber 2015, p. 9)

\section{Finally}

In the upcoming Chaps. 7, 8 and 9, we will unpack these developments in more detail as we empirically study the designs and local enactments of evaluation in HE. We will also show how the evolving group of professionals working with quality issues in the higher-education sector, the qualocrats, are making their mark in these processes of quality assurance enactment. Questions of autonomy, power, and expansion have been accentuated over time, and we will continue to explore how these issues unfold as the 2016 system is designed and put in place. The next chapter, however, focuses on how the debated 2011-2014 EQA system was carried out in terms of its media display and framing of evaluation results from evaluations of study programmes within individual HEIs. The next chapter thereby elaborates on the mediatised activities and work undertaken within the 2011-2014 EQA system and draws attention to how the communications of and with the media were formed and framed by both the responsible national agencies and the HEIs themselves.

\section{References}

Abdallah, L. (2002). Process eller resultat? Trender inom utvärdering av svensk högskoleutbildning pa 1990-talet [Process or result? Trends in evaluation of Swedish higher education in the 1990s] (Working paper 2002:20). Stockholm: SISTER.

Aylott, N., \& Bolin, N. (2015). Polarising pluralism: The Swedish parliamentary election of September 2014. West European Politics, 38(3), 730-740.

Bennich-Björkman, L. (2002). Någonting har hänt. Förbättring och frustration i svenska lågstatusskolor [Something has happened. Improvement and frustration in Swedish low-status schools]. Stockholm: SNS.

Dahler-Larsen, P. (2011). Evaluation society. Stanford: Stanford University Press.

Dahllöf, U. (1999). Det tidiga ramfaktorteoretiska tänkandet. En tillbakablick [The early framefactor theoretical thinking. A flashback]. Pedagogisk Forskning i Sverige, 4(1), 5-29.

ENQA. (2014). Sweden develops a new system for quality assurance. http://www.enqa.eu/index. php/sweden-develops-a-new-system-for-quality-assurance/. Accessed 2 Aug 2018.

Foss, N. J., \& Klein, P. G. (2013). Hayek and organizational studies. Journal of Chemical Information and Modeling, 53(9), 1689-1699.

Franke-Wikberg, S. (1992). Utvärderingens mångfald: några ledtrådar för vilsna utbildare [The diversity of evaluation: some clues for lost educators] (Projektrapport 1992:4). Stockholm: UHÄ. 
Freeman, R., \& Maybin, J. (2011). Documents, practices and policy. Evidence \& Policy: A Journal of Research, Debate and Practice, 7(2), 155-170.

Government Bill 2009/2010:139. Fokus på kunskap - kvalitet $i$ den högre utbildningen [Focus on knowledge - Quality in higher education]. Stockholm: Utbildningsdepartementet.

Graeber, D. (2015). The utopia of rules. On technology, stupidity, and the secret joys of bureaucracy. New York: Melville House Publishing.

Gröjer, A. (2004). Den utvärdera(n)de staten [The evaluative state]. Stockholm: Stockholm University: Department of Political Science.

Hayek, F. (1945). The use of knowledge in society. American Economic Review, 35(4), 519-530.

Hsieh, H.-F., \& Shannon, S. E. (2005). Three approaches to qualitative content analysis. Qualitative Health Research, 15(9), 1277-1288.

Jarl, M., \& Rönnberg, L. (2019). Skolpolitik. Från Riksdagshus till klassrum [School politics. From the parliament building to the class room] (3rd ed.). Stockholm: Liber.

Jarvis, D. S. L. (2014). Regulating higher education: Quality assurance and neo-liberal managerialism in higher education-A critical introduction. Policy \& Society, 33(3), 155-166.

Jessop, B. (2015). The state: Past, present, future. Cambridge, UK: Polity Press.

Kaliber. (2013). Högskolans kvalitetsmätning kritiseras internationellt [Quality measurement within higher education internationally criticized]. https://sverigesradio.se/sida/avsnitt/25844 2? programid=1316. Accessed 2 Aug 2018.

Lewin, L. (2002). "Bråka inte!" Om vår tids demokratisyn ["Do not fight!" About our contemporary view on democracy]. Stockholm: SNS.

Lindgren J. \& Rönnberg, L. (2015). The emotional politics of policy processes. Governing in and by quality evaluation reforms in Swedish Higher Education. Paper presented at the European Conference of Educational Research (ECER) in Budapest, Hungary, September 7-11, 2015.

Lindgren, J., \& Rönnberg, L. (2018). The emotional politics of quality assurance reform: Shifting affective atmospheres in Swedish higher education policy. Higher Education Policy, 31(1), $55-73$.

Lindvall, J., \& Rothstein, B. (2006). Sweden: The fall of the strong state. Scandinavian Political Studies, 29(1), 47-63.

Ministry of Education. (2015). Kvalitetssäkring av högre utbildning [Quality assurance of higher education] (Promemoria. U2015/1626/UH). Stockholm: Utbildningsdepartementet.

Parliament Minutes. (2010). Riksdagens protokoll 2009/10:130. Stockholm: Riksdagen.

Parliament Minutes. (2016). Riksdagens protokoll 2015/16:70. Stockholm: Riksdagen.

Parliament Standing Committee on Education. (2010). Fokus på kunskap - kvalitet $i$ den högre utbildningen [Focus on Knowledge - quality in Higher Education] Utbildningsutskottets betänkande 2009/10:UbU20. Stockholm: Riksdagen.

Peck, J., \& Theodore, N. (2015). Fast policy: experimental statecraft at the thresholds of neoliberalism. Minneapolis: University of Minnesota Press.

Rönnberg, L., \& Lindgren, J. (2015). Drive-by governing and policy rerouting: The case of quality evaluations in Swedish higher education. Paper presented at the 43rd Annual Congress of the Nordic Educational Research Association (NERA), NW21: Politics of Education and Education Policy Studies, March 4-6. Sweden: Gothenburg.

Rosa, H. (2013). Social acceleration: A new theory of modernity. New York: Columbia University Press.

Saunders, M. (2014). Quality enhancement: An overview of lessons from the Scottish experience. In M. J. Rosa \& A. Amaral (Eds.), Quality assurance in higher education (pp. 117-131). London: Palgrave.

SHEA. (2014a). Förslag till nytt kvalitetssäkringssystem. Ej färdigt förslag [Proposal for a new quality assurance system. Preliminary proposal]. Presentation 2014-10-28'. http://www.uka.se/ download/18.6cd9c6e9149126b701528a3d/1414662216085/presentation-preliminart-forslagnytt-utvsystem-28okt.pdf. Accessed 22 Jan 2015.

SHEA. (2014b). Evaluation process 2011-2014. http://www.uka.se/qualityassurance/standardeval uationprocess.4.4149f55713bbd917563800010219.html. Accessed 11 Oct 2016. 
SHEA. (2015). Utbildningsutvärderingarnas effekter. En genomgång av effekterna av det nationella utvärderingssystemet 2011-2014 [Effects of programme evaluations. A review of effects of the national evaluation system 2011-2014] (Rapport 2015:21). Stockholm: Universitetskanslersämbetet.

SHEA. (2016). Värdefull input om nya kvalitetssystemet [Valuable input about the new quality system]. http://www.uka.se/nyheter/2016-06-22-vardefull-input-om-nya-kvalitetssystemet.html. Accessed 1 Sept 2016.

SHEA. (2017). Erfarenheter och lärdomar av kvalietsutvärderingar 2011-2014 [Experiences and lessons from quality evaluations 2011-2014] (Rapport 2017:10). Stockholm: Universitetskanslersämbetet.

SNAHE. (2009). Kvalitetsutvärdering för lärande [Quality evaluation for learning] (Report 2009:25 R). Stockholm: Högskoleverket.

Sørensen, M. P., \& Mejlgaard, N. (2014). Autonomi och kvalitet - ett uppföljningsprojekt om implementering och effekter av två högskolereformer $i$ Sverige. Delredovisning 2: Intervjuundersökning med rektorer [Autonomy and quality - A follow-up study on the implementation and effects of two reforms in the Swedish higher education system. Sub-study 2: Interview study with the rectors]. Stockholm: Riksdagen.

Sørensen, M. P., Haase, S., Graversen, E. K., Kalpazidou Schmidt, E., Mejlgaard, N., Ryan, T. K., Björk, A., Møller Grønfeldt, L., Bargmann Madsen, E., \& Nyberg, M. E. (2015). Autonomi och kvalitet - Ett uppföljningsprojekt om implementering och effekter av två högskolereformer $i$ Sverige [Autonomy and quality - A follow-up study on the implementation and effects of two reforms in the Swedish higher education system. Main report]. Stockholm: Riksdagen.

Stensaker, B. (2007). Quality as fashion: Exploring the translation of a management idea into higher education. In D. F. Westerheijden, B. Stensaker, \& M. J. Rosa (Eds.), Quality assurance in higher education: Trends in regulation, translation and transformation (pp. 99-118). Dordrecht: Springer.

Takayama, K., Lewis, S., Gulson, K., \& Hursh, D. (2017). Fast policy: Experimental statecraft at the thresholds of neoliberalism. Discourse: Studies in the Cultural Politics of Education, 38(2), 292-316.

Toots, A., \& Kalev, L. (2016). Governing in the shadow of Bologna: Return of the state in higher education quality assurance policy. International Journal of Public Policy, 12(1-2), 54-70.

Vedung. (1998). Utvärdering i Politik och förvaltning [Evaluation in politics and administration] (2nd ed.). Lund: Studentlitteratur.

Vedung, E. (2000) Public policy and program evaluation. New York: Transaction publishers.

Weiss, C. (1998). Evaluation: Methods for studying programs and policies (2nd ed.). Upper Saddle River: Prentice Hall.

Open Access This chapter is licensed under the terms of the Creative Commons Attribution 4.0 International License (http://creativecommons.org/licenses/by/4.0/), which permits use, sharing, adaptation, distribution and reproduction in any medium or format, as long as you give appropriate credit to the original author(s) and the source, provide a link to the Creative Commons license and indicate if changes were made.

The images or other third party material in this chapter are included in the chapter's Creative Commons license, unless indicated otherwise in a credit line to the material. If material is not included in the chapter's Creative Commons license and your intended use is not permitted by statutory regulation or exceeds the permitted use, you will need to obtain permission directly from the copyright holder.

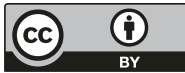




\title{
Quality Evaluations and the Media
}

\author{
Linda Rönnberg
}

\begin{abstract}
The aim of this chapter is to analyse how results from the 2011 to 2014 national evaluation and quality assurance (EQA) system were communicated to and via the media. First, the analysis focuses on the attempted media framing, as manifested in press releases of national evaluations from the responsible national agencies. Second, the higher education institution-media interactions, in the context of two national quality evaluations from two subject areas (education and specialist nursing), are analysed from the perspective of how four higher education institutions' attempted framings were (re)presented by the media. The chapter concludes with a discussion pointing to interdependence and possible reinforcement of the media-quality assurance relationship and points to some possible implications for education governing. The chapter also discusses the silences and articulations that could not be detected in the studied data, as situated within the context of reputation management and media display in the contemporary "evaluation society".
\end{abstract}

\section{Introduction}

This chapter continues to explore the governing-evaluation-knowledge interactions in Swedish higher education, now in the context of media exposure, display, and management. This chapter analyses the highly debated national quality assurance and evaluation (EQA) system in operation from 2011 to 2014 that was described in the previous chapter, with a focus on how the actual evaluations performed as a result of this EQA system were mediated and displayed "in the public eye". Today, media reporting on national evaluations and quality assurance are high stakes for the parties involved. For the higher education institutions (HEIs), attracting future students and a favourable "branding" not only depends on the actual outcome of the evaluation but also, importantly enough, on how the outcomes are reported and

\footnotetext{
L. Rönnberg $(\bowtie)$

Department of Applied Educational Science, Umeå University, Umeå, Sweden

e-mail: linda.ronnberg@umu.se
}

C. Segerholm et al. (eds.), The Governing-Evaluation-Knowledge Nexus, Evaluating Education: Normative Systems and Institutional Practices, https://doi.org/10.1007/978-3-030-21143-1_6 
represented by the media and thereby transmitted to the wider public and to different stakeholders. Media display is also important for the evaluation agencies, and media coverage is in itself displayed as a sign of both policy and agency "success".

As described in the chapter "National Evaluation Systems", this has not always been the case. Since the introduction of the per-student state grant system, the incentives for HEI branding and PR activities as well as the potential risk of unfavourable media exposure have risen considerably. In this context, the 2011-2014 EQA system can be said to have raised the stakes even more. It included both sanctions and rewards. Each HEI and programme was given a grade. The top performers received extra funding, and the lowest grade could result in a revoked licence to issue degrees. In addition, the evaluations of study programmes and the resulting grades were to be comparable across universities, as a form of "customer information" for prospective students. To aid in this ambition, the evaluation reports were standardised, made publicly available, and intended to speak to a wide audience. Taken together, the design of the 2011-2014 EQA system seems to go well with the "media logic" (see below), in which winners and losers, the potential for scandal, and the issuing of rewards and sanctions tend to be prioritised angles of reporting.

The aim of this chapter is to analyse how evaluation results were communicated to and via the media, by studying media communication and the display of national EQA, in the form of quality evaluations of higher education study programmes in operation from 2011 to 2014. The following questions are addressed:

- How were the evaluations communicated to the media, and how did the regional media portray the HEIs in the context of national quality evaluations?

- Did the media coverage reinforce the representations attempted by the responsible agency and the HEIs, or were these images challenged?

- How can the media-quality assurance relationships be understood in light of the two questions above, and what are the implications for governing?

Next, some conceptual tools and frames are introduced along with some brief notes on the empirical data used in the particular study reported in this chapter. This is followed, first, by a mapping of the attempted framing of the evaluation results made by the two national evaluation agencies (the Swedish Higher Education Authority and the National Agency for Higher Education, with the first replacing the second in 2013), by analysing their press releases from 2011 to 2016. Second, two particular quality evaluations are focused upon, namely, education and specialist nursing, to highlight how four HEIs' attempted framings were (re)presented by the media. The chapter concludes with a discussion of these findings by pointing to the interdependence and possible reinforcement of the media-quality assurance relationship and by arguing that these have important implications for education governing. 


\section{Approaching the Media-Quality Assurance Relationship}

This chapter focuses on some of the intersections of the "media society" and the "audit society" in the form of public agency evaluations of HEIs and seeks to explore some of the dual dependencies that these relationships entail and fortify, arguing that they constitute interesting tensions for further exploration from the perspective of governing. On the one hand, the media provide certain interpretative frames by conditioning "rules of the game," by allowing certain voices to speak and silencing others, and by operating according to a particular format and logic of communication (Hjarvard 2013). At the same time, media reporting depends on receiving certain information and material from perceived credible and legitimate sources, such as agencies and universities (cf. Fredriksson and Pallas 2016; Thorbjørnsrud 2015; Rönnberg et al. 2013).

The study reported in this chapter draws on literature related to different dimensions of media-education governing interactions, including (a) governance and governing work (Clarke 2015; Bell et al. 2010; Newman and Clarke 2009); (b) literature conceptualising the relationship between media, society, and policy/politics/bureaucracy (Christensen and Gornitzka 2018; Crow and Lawlor 2016; Thorbjørnsrud 2015; Hjarvard 2013; Strömbäck 2008); and (c) literature more specifically targeting the media in the context of education as a policy field (Rawolle 2010; Thomas 2009; Anderson 2007; Gewirtz et al. 2004).

In the contemporary "audit society" (Power 1999), scrutiny, evaluation, and control are prominent means of governing institutions, organisations, and professionals (Dahler-Larsen 2011; Grek and Lindgren 2015). The field of higher education is no exception. Under the umbrella of New Public Management, different evaluative activities are linked to and promoted by developments entailing the increased marketisation and privatisation of public welfare, in both Europe and beyond. Within such an agenda, higher education is increasingly conceived as a form of private good (Englund 1996), which positions students as consumers and quality evaluations as means by which to assist, account, regulate, and even fortify these relationships. As expressed by Tomlinson (2017):

[t]he comparative dimension of universities' performance in the form of league tables and information sets is seen as crucial in information [of] student "choice". Consumerism is portrayed as part of an increasingly subservient and defensive institutional climate that reflects a largely reactive position of professional accountability to external stakeholders' demands for transparent forms of provision that meet instant gratification needs. (Tomlinson 2017, p. 454)

Such "needs" are reinforced, shaped, and channelled by media reporting and media displays of evaluation information, not least when the evaluation information can be ranked and league tabled in a format fitting the "media logic" (Altheide and Snow 1979). Media outlets thus actively contribute to constructions of meaning (Thomas 2009; cf. Dahler-Larsen 2012 on constitutive effects). In a way, both the media and public agencies that rank and evaluate HEI performance can be argued to be aligned with a public mission to scrutinise - they are often perceived as defend- 
ers and enhancers of the public interest. But they also have fundamental differences. The national agency is an integral part of the state and its bureaucracy, in the form of public administration. News media are not bound by such formal or legislated obligations.

\section{Logics of Appropriateness}

In the language of normative institutionalism, there is a certain logic of appropriateness in operation: of taken-for-granted routines and operations defining action and relations (March and Olsen 1989, 2006), "collections of interrelated rules and routines that define appropriate action in terms of relations between roles and situations" (Peters 1999). The "media logic" (Altheide and Snow 1979) is signified by providing fast and easy access, readership-friendly accounts, etc. The media logic tends to favour "unambiguity, episodic frames (...) to focus on conflicts and has a prevailing negative bias (...) designating roles of heroes, victims and villains" (Thorbjørnsrud 2015, p. 181).

The media intersects - and perhaps collides - with bureaucratic ideals or visions. Such bureaucratic virtues are often conceptualised in terms of, for instance, impartiality, correctness, neutrality, or adhering to regulations. These key terms describing bureaucratic ideals may not be easily aligned with the media logic, at first glance (Thorbjørnsrud 2015). In this chapter, some of the instances when media logic and bureaucratic public agency work intersect will be pinpointed and examined through the evaluations performed within the 2011-2014 EQA.

\section{The Public Agency-Media Relationship}

At the outset and from the agency perspective, at least three strategies or responses can be identified for the agency/HEI-(news) media relationship: to accommodate, to be proactive, and/or to be protective (cf. Table 1):

Table 1 Public administration and news media interactions: strategies and stances

\begin{tabular}{|c|c|c|}
\hline Adapting and balancing & Bureaucratic branding & Information control \\
\hline $\begin{array}{l}\text { Accommodating: Providing } \\
\text { information that accommodates the } \\
\text { formats and timing of the media } \\
\text { logic as well as short, quick } \\
\text { answers, in combination with } \\
\text { upholding bureaucratic ideals of } \\
\text { correctness and accuracy (to a } \\
\text { greater or lesser extent) }\end{array}$ & $\begin{array}{l}\text { Proactive: Actively } \\
\text { promoting positive and } \\
\text { favourable images of the } \\
\text { agency/institution; pitching } \\
\text { positive news; spreading the } \\
\text { image of a well-run, } \\
\text { goal-oriented, and rational } \\
\text { system, successful steering, } \\
\text { etc. }\end{array}$ & $\begin{array}{l}\text { Protective: Controlling and } \\
\text { steering within the } \\
\text { institution before it goes } \\
\text { public, to secure uniform } \\
\text { and coherent messages } \\
\text { across levels and subunits, } \\
\text { etc. and to control and } \\
\text { streamline what reaches } \\
\text { journalists }\end{array}$ \\
\hline
\end{tabular}

Source: Adapted and revised from Thorbjørnsrud (2015, pp. 192-193) 
These three strategies, along with their compatibility with the media logic of appropriateness versus the bureaucratic ideal, will first be discussed in relation to the attempted framings and media communications by the agency and the selected HEIs (see below). Secondly, they will underpin the analysis of HEI-media interactions in the context of results from two national subject area evaluations performed by the responsible national agency within the framework of the 2011-2014 EQA system.

\section{Cases and Empirical Sources}

The study focuses on a selection of HEIs. These cases have been selected as a part of the research project to represent different overall outcomes in the national evaluations (in terms of share of study programmes judged as "inadequate", cf. Ericson 2014) and different institutional characteristics (university versus university college; old established institution or younger). This multiple case study (Stake 2006) thereby came to include four HEIs that displayed variety in terms of age, size, specialisation, and geographical location and were characterised by different contextual conditions as well as different outcomes to the national quality evaluations (see also Table 1 in the chapter "Enacting a National Reform Interval in Times of Uncertainty: Evaluation Gluttony Among the Willing").

In brief, Orion is a large old university with several faculties and subject areas that overall did well in the evaluations on an aggregate level, Hercules is an old and specialised university with one faculty and mainly professional programmes that did not do as well, Virgo is a comparably recently established university college with mainly professional programmes that did well in the national evaluations, and Pegasus is a comparably recently established university with both professional and academic programmes and courses that overall did not see much success in the national evaluations.

This chapter is based on a range of different empirical sources: first, press releases and evaluation reports from the responsible national evaluation agency (SHEA) and its predecessor (SNAHE) and second, press releases and information from the four HEIs' webpages, such as communication policies and records/ archives of press releases. Some press releases were hard to retrieve, as they date back several years, and the websites may not be updated. For some of these instances, a report from Academic Rights Watch (2015) - a foundation instigated to safeguard academic freedom and rights - has been valuable for tracing and obtaining press releases from the four studied HEIs. Third, media articles from the Swedish media database, Mediearkivet, were analysed, using search terms such as the HEI's name, the evaluation agency's name, and the subject area. To ensure confidentiality for the participants in the HEIs, the newspapers are not explicitly mentioned or listed as references. These searches did not provide an overall picture of the media debate in general but were focused on the particular HEIs and the selected subject areas. This means that the more general and national debate going on the 
time (cf. chapter "Hayek and the Red Tape: The Politics of Evaluation and Quality Assurance Reform - From Shortcut Governing to Policy Rerouting") is not included as a result of the particular selection criteria employed in this media study. Finally, the chapter also uses data collected within the wider research project that were analysed to provide additional contextual understanding of the four HEIs, including interviews with vice chancellors and senior management at the faculty level at the four HEIs.

The data has been ordered by thematic coding. For the press releases, the themes were derived from the main attempted "pitch", i.e. if the texts were mainly highlighting positive aspects or negative aspects, or if they were mixed press releases (with both top and low performers highlighted by the agency) or neutral press releases, with no value statements or attempted anglings present. In the primarily local media reportings, the thematic coding targeted how the media angling was related to the HEI press release, who was allowed to speak (by quotes in the articles), and in what role and context (for instance, as shamed or blamed or as heroes/ winners) (cf. Ekecrantz and Olsson 1991).

Before turning to the empirical study, the next section briefly provides some additional background and information on the processes and rationale of the national agency quality evaluations within the 2011-2014 EQA system.

\section{The Policy Context and the 2011-2014 EQA System}

In general, Sweden has followed the same kind of overall reform that other EU and OECD countries have undergone. The keywords of these reform efforts include, for instance, efficiency, transparency, customer orientation, and accountability, with an intensified focus on comparisons, data, indicators, and reinforcement of external evaluation. Drawing on Karlsson et al. (2014), the following main traits can be highlighted in the recent Swedish higher education policy context. The first are aspects relating to the HEIs and their relationship with the external environment. Reforms have been launched that can be expressed in terms of marketisation and competition, including an intensified hunt for resources. Even if attending Swedish higher education is free of charge, HEIs receive public funding based on the number of students they enrol. In addition, the introduction of tuition fees for non-EU citizens in 2011 marked a break with the former non-fee-paying system of Swedish HE. There is also an intensified emphasis on ranking and league tables, aimed at steering and guiding the potential "customer", in the wake of these general developments (see, for instance, the development of a Web-based tool to be used for comparisons between HEIs and with regard to their quality, as assessed in the 2016 EQA system) (SHEA 2018).

Secondly, reforms have also targeted what happens inside the HEIs, by reforming university management and organisation. Overall, several recent Swedish higher-education policies are aimed at HEIs taking a more active, self-governing role, which is assumed to lead to increased efficiency and improved outcomes. The 
so-called autonomy reform (Government Bill 2009/2010:149) is one example of the striving to make HEIs more independent and self-governing in some respects, such as with regard to internal organisation and hiring and promotion of staff. In these reform efforts, several performance-monitoring measures have been instigated by the state, such as audits, indicators, and intensified external evaluation. Bibliometric follow-up of research and the 2011-2014 EQA system are just two examples. As we saw in the previous chapter, the latter has also contributed to sparking a wider debate about trust and accountability in Swedish HE (see also Karlsson et al. 2014; cf. Kettis and Lindberg-Sand 2013).

As described in the chapter "Hayek and the Red Tape: The Politics of Evaluation and Quality Assurance Reform - From Shortcut Governing to Policy Rerouting", Sweden introduced a highly debated evaluation framework for assessing quality in higher education in 2011 that was explicitly focused on results and student outcomes: the 2011-2014 EQA system. Implementing this framework led to the Swedish agency being excluded from the European Association for Quality Assurance in Higher Education (ENQA), of which Sweden originally had been one of the founding members (see chapter "Europe in Sweden" and Segerholm and Hult 2015). Among other things, the Swedish EQA system at the time did not consider HEIs' internal quality-assurance procedures. It only focused on student results and outcomes, which the ENQA criticised, and turned out to be an infected and decisive issue in the Swedish policy discourse. In addition, the fast-paced "shortcut" policy process and detailed instructions set up by the ministry were an additional and important part of the criticism, targeting both content and the process by which it was designed and approved (cf. chapter "Hayek and the Red Tape: The Politics of Evaluation and Quality Assurance Reform - From Shortcut Governing to Policy Rerouting").

The 2011-2014 EQA system targeted study programmes that could lead to the award of a first- or second-cycle qualification and assessed the extent to which the students' learning outcomes corresponded to the intended learning outcome: the main assessment point was students' independent projects (called final degree projects). The evaluation resulted in a final overall grade of very high, high, or inadequate quality. The lowest grade meant a follow-up by the agency, with the possibility of a revoked entitlement to award degree qualifications (SHEA 2014a). Extra funding was given to top performers (highest grade). The evaluations in full, and not only the final grade, were then made public on the agency's website, most often followed by a press release from the agency.

The media searches and the data collection in this chapter target the 2011-2014 EQA system as well as the period 2014-2016, when SHEA was preparing for a new EQA system but continued to carry out follow-ups, which we label a "reform interval" (see the chapter "Enacting a National Reform Interval in Times of Uncertainty: Evaluation Gluttony Among the Willing"). To specify, no additional or new evaluations of study programmes were undertaken during this period, but the HEIs that had failed and received the inadequate quality grade were reassessed to see if they could now be passed or not. 


\section{Evaluation Agency Framing of the Evaluation Results}

As stated in the introduction to this chapter, media display is indeed high stakes for HEIs. But media reporting is important to the evaluation agencies as well. This is visible in the SHEA's annual report of its activities, directed to the government and the general public:

Our work receives much external attention and interest. This is obvious, not least, by the fact that media reporting on SHEA had a three-fold increase compared to last year. The agency's work is important and contributes to improving Swedish Higher Education. (SHEA 2015, p. 4)

As the above quote illustrates, media coverage is in itself displayed as a sign of policy and agency success and is linked to the mission to improve HE. As Gewirtz et al. note, "(c)ertain policies require the demonstration of progress and success and (...) this in itself becomes an intrinsic feature of the policies" (Gewirtz et al. 2004, p. 327). Given the importance of the media and display, and also as a means of actually making the policy "work", the next section focuses on the evaluation agencies' media communication by analysing their press releases.

Relevant press releases issued by the responsible agencies (the SNAHE and then the SHEA) were collected for the years 2011-2016 $(N=36)$ on the topic of evaluations of study programmes. As previously mentioned, the analysis sought to identify their framing by categorising them as mainly positive, negative, mixed, or neutral (Table 2).

In the positive category, many releases were about follow-ups conducted one year after a programme had been judged as inadequate. Very few programmes were ever revoked of their rights to issue degrees. The positive evaluation results - since almost all of the programmes passed the follow-ups - also function as an implicit justification of the agency (compare to bureaucratic branding), as "now" there has

Table 2 SNAHE and SHEA evaluation results press releases, 2011-2016 $(N=36)$

\begin{tabular}{l|l}
\hline $\begin{array}{l}\text { Positive } \\
(n=6)\end{array}$ & $\begin{array}{l}\text { A majority of the follow-ups are in this category; almost all reassessed programmes } \\
\text { were judged as high quality, thereby shedding positive light on the agency as well as } \\
\text { claims that the 2011-2014 EQA system had in fact resulted in a "significant raise in } \\
\text { quality" }\end{array}$ \\
\hline $\begin{array}{l}\text { Mixed } \\
(n=11)\end{array}$ & $\begin{array}{l}\text { Expressed as, for instance, "mixed quality in artistic training" (and several other } \\
\text { subjects were expressed in the same way), i.e. the releases mention both negative } \\
\text { and positive results. Often, these press releases begin with and emphasise the failed } \\
\text { and lacking programmes and HEIs and then mention top performers }\end{array}$ \\
\hline $\begin{array}{l}\text { Negative } \\
(n=6)\end{array}$ & $\begin{array}{l}\text { Mainly focusing on and framing the release in terms of failures, such as "several } \\
\text { programmes failed", "many programmes failed", or "midwife training programmes } \\
\text { are insufficient". (Note: none of these midwife programmes earned the highest } \\
\text { grade, as 15 were judged as high quality, and only 3 as lacking quality, but the } \\
\text { headline of the press releases still concluded "insufficient") }\end{array}$ \\
\hline $\begin{array}{l}\text { Neutral } \\
(n=13)\end{array}$ & $\begin{array}{l}\text { These press releases are stating a new evaluation that has been completed and } \\
\text { published, no quotes that are assessing/valuing the results, with headlines such as } \\
\text { "New evaluations", "Evaluations now finished", etc. }\end{array}$ \\
\hline
\end{tabular}


been "a significant increase in quality", as the headline may say, i.e. the agency and its evaluation work matter, and they raise quality. The analysis of agency press releases thereby illustrates how a favourable bureaucratic branding strategy is discernible within this format of directed media communications. This can be interpreted within the performative dimension of agency reputation management (Christensen and Gornitzka 2018), in which the agency is delivering outcomes relating to its core mission.

The analysis also identified mixed press releases, which highlighted both negative and positive aspects. These releases often begin by describing what is lacking and how many and what HEIs failed or were found inadequate, but the releases also mention top performers and those who got the very high quality grade, which received an extra government grant - as a way to single out the "heroes".

Looking at the negative press releases, they are in themselves attractive to the media logic; "failures", etc. give leeway to feelings of sensation and even scandal, victimised students, and evil, underperforming HEIs. The midwife training press release can serve as an example: "Midwife training programmes are inadequate" headlined the press release, but in fact only 3 programmes were judged as inadequate, and 15 passed with high quality. The neutral press releases were the most common framing. These releases merely state that "a new evaluation is finished" and list the results, without any quotes, opinions, or statements from agency representatives.

\section{Media Coverage of Two Subject Areas}

In the coming sections, some results on two subject areas are presented in more detail, in the particular context of the four studied HEIs. The first area, education, had a mixed press release, and the second, specialist nursing, had a negative one. Both categories can be said to connect well with the media, based on what the media logic would amplify and value (negative angles, villains, deviations rather than success stories, etc.). Furthermore, these subject areas concern professional degrees and are large programmes that are important for meeting the demand for qualified staff in the whole of Sweden, making them courses and programmes of particular public and political interest.

\section{Education}

The education subject area comprised programmes in education, specified as also including didactics, educational leadership, and psychotherapy. The SHEA launched a "mixed" press release:

One third of all programs, 19 out of 57, got the grade inadequate quality. These programs are offered in 12 out of the total 24 HEIs assessed in this evaluation. The shortcomings are 
often connected to lacking scientific quality in students' independent degree projects" (...) Five programs are judged as very high quality and will receive an extra quality grant from the government, and 33 programs are of high quality. (SHEA 2014b)

The table below summarises the HEIs' results in the evaluation, how they presented the evaluation results themselves, and the (mainly regional) media coverage (Table 3).

In Orion's case, the "inadequate" grade was not mentioned in the HEI press release, but it was picked up by the student union journal. Other than that, there was little media attention. Hercules chose to communicate and highlight its very high grade (not the high grade), but there was not much media response and attention. Virgo had one evaluated programme that got the grade "high quality", which was also highlighted in a press release. This was followed by a "kind" and smooth follow-up and exposure in a local newspaper that even "advertised" how students would go about applying to this successful programme (which did not even receive the highest grade), by stating the deadlines for applications, who to contact, etc. Pegasus had mixed results, and the regional paper chose to highlight the good grade

Table 3 Subject area: Education

\begin{tabular}{|c|c|c|}
\hline $\begin{array}{l}\text { HEI and } \\
\text { evaluation } \\
\text { results }\end{array}$ & $\begin{array}{l}\text { HEI news and/or press } \\
\text { release }\end{array}$ & Media coverage \\
\hline $\begin{array}{l}\text { Orion } \\
\text { Six evaluations: } \\
\text { Very high: } 4 \\
\text { High: } 2 \\
\text { Inadequate: } 1\end{array}$ & $\begin{array}{l}\text { "Good grades for } \\
\text { [Orion's] certification } \\
\text { degrees in didactics, } \\
\text { educational leadership, } \\
\text { and education" }\end{array}$ & $\begin{array}{l}\text { The student union journal reported that "Education } \\
\text { has inadequate quality", relying on the SHEA press } \\
\text { release and an interview with an Orion } \\
\text { representative saying, "we are taking this very } \\
\text { seriously", and that Orion has already started } \\
\text { improvement work. }\end{array}$ \\
\hline $\begin{array}{l}\text { Hercules } \\
\text { Three } \\
\text { evaluations: } \\
\text { Very high: } 1 \\
\text { High: } 2\end{array}$ & $\begin{array}{l}\text { "The certification } \\
\text { degree in } \\
\text { psychotherapy gets the } \\
\text { grade of very high } \\
\text { quality" }\end{array}$ & $\begin{array}{l}\text { No reporting with Hercules as a focal point (this } \\
\text { HEI is only mentioned in articles that report a full } \\
\text { list of all evaluated HEIs). }\end{array}$ \\
\hline $\begin{array}{l}\text { Virgo } \\
\text { One evaluation: } \\
\text { High: } 1\end{array}$ & $\begin{array}{l}\text { "[Virgo's] certification } \\
\text { degree in education is } \\
\text { of high quality" }\end{array}$ & $\begin{array}{l}\text { A regional paper ran the headline "High quality at } \\
\text { the university" and quotes the vice chancellor from } \\
\text { the HEI press release, along with another positive } \\
\text { voice from a Virgo representative. Finally, the article } \\
\text { provides an "advertisement" to prospective students } \\
\text { by stating, "the next opportunity to apply for the } \\
\text { programme is..." }\end{array}$ \\
\hline $\begin{array}{l}\text { Pegasus } \\
\text { Two evaluations: } \\
\text { High: } 1 \\
\text { Inadequate: } 1\end{array}$ & $\begin{array}{l}\text { "Mixed results in } \\
\text { evaluation of } \\
\text { education" }\end{array}$ & $\begin{array}{l}\text { A regional paper stated that the "second cycle } \\
\text { degree gets good grade" and "it was both good and } \\
\text { bad grades when courses in education were graded } \\
\text { and evaluated". A Pegasus representative is quoted } \\
\text { saying they have already started the improvement } \\
\text { work and will continue it and take the criticism } \\
\text { seriously. The final sentence reiterates the grade } \\
\text { "high quality" for one of the evaluated degrees. }\end{array}$ \\
\hline
\end{tabular}


in its headline. It also allowed Pegasus representatives to elaborate and assure the readers that it was working to improve.

\section{Specialist Nursing}

The results from the evaluation of specialist nursing and care led the SHEA to launch quite a negative press release:

The SHEA has finalised a comprehensive evaluation of programs in specialist nursing and care. Seventy-nine out of 134 programs are judged as having inadequate quality, and their right to reward degree qualifications is now questioned. This is a serious situation, and the HEIs of course need to rectify this (...), says University Chancellor Harriet Wallberg. (SHEA 2014c)

This particular evaluation made it to the national news and was distributed by the main national news agency TT. It then travelled to other regional media outlets. Table 4 below shows how the HEIs communicated the evaluation results, alongside whether and how the evaluations were picked up and framed by (the regional) news media.

As displayed in the table, Orion attempted a framing, but the regional paper went for the national news agency's formulations. Hercules had very bad results and did some damage control attempts in its releases, by being open and receptive and stating it is working hard to improve. This made it to the national media. Virgo did well and took advantage of it. The "hero story" it launched successfully came through in the subsequent media coverage. Pegasus had three regional outlets that covered the story. Two did their own articles, while one went for the national TT news agency text. The two articles written by local journalists let Pegasus representatives explain and expand that they were working hard to improve.

\section{Media Communication, Agencies, and Evaluation}

The analysis in this chapter showed that the agencies' press releases varied in their "pitch" and that they are displaying signs of bureaucratic branding, such as in the follow-up press releases from the national evaluation agencies (compare to performative reputation management, Christensen and Gornitzka 2018). The negative releases also showed some tendencies to scandalise, as illustrated by the midwife evaluation press release. Press releases from the HEIs also varied in their attempted angling, unsurprisingly attempting to frame the issue in a favourable and constructive light but not always. There was noticeable variation in this regard.

Throughout the study, the evaluation agencies (the SNAHE and the SHEA) appeared to be conceived as an untouchable form for check-up. They are perceived as credible, reliant, and good sources of non-biased information that the media is 
Table 4 Subject area: Specialist nursing

\begin{tabular}{|c|c|c|}
\hline $\begin{array}{l}\text { HEI and } \\
\text { evaluation results }\end{array}$ & $\begin{array}{l}\text { HEI news and/or press } \\
\text { release }\end{array}$ & Media coverage \\
\hline $\begin{array}{l}\text { Orion } \\
\text { Nine evaluations: } \\
\text { High: } 3 \\
\text { Inadequate: } 6\end{array}$ & $\begin{array}{l}\text { "Many specialist nursing } \\
\text { programmes are } \\
\text { questioned"; } \\
\text { "A few was judged as } \\
\text { lacking quality"; "We are } \\
\text { happy to see that several } \\
\text { programmes were graded } \\
\text { as high quality on some } \\
\text { of the assessment points" } \\
\text { (faculty-level chair) }\end{array}$ & $\begin{array}{l}\text { A regional newspaper stated, "Major flaws in } \\
\text { nursing education". } \\
\text { This text is from the national news agency TT, } \\
\text { quoting the chancellor emphasising the } \\
\text { seriousness of the situation and that this was a } \\
\text { national problem that should be seen as an issue } \\
\text { for the government and not just the HEIs. The } \\
\text { final part lists Orion's results. }\end{array}$ \\
\hline $\begin{array}{l}\text { Hercules } \\
\text { Ten evaluations: } \\
\text { High: } 1 \\
\text { Inadequate: } 9\end{array}$ & $\begin{array}{l}\text { "Special nursing } \\
\text { education is questioned in } \\
\text { a new evaluation"; } \\
\text { "Scientific quality is } \\
\text { lacking"; } \\
\text { Quoting a dean: "We } \\
\text { should not offer } \\
\text { education that is lacking } \\
\text { quality. We will work to } \\
\text { ensure that all our } \\
\text { programmes are of high } \\
\text { quality" }\end{array}$ & $\begin{array}{l}\text { National TV news: "Special nursing education } \\
\text { heavily criticised". Hercules' representative was } \\
\text { interviewed and said it took this seriously and } \\
\text { needed to make an extensive improvement } \\
\text { effort, portraying Hercules as already on the } \\
\text { route to successful improvement. } \\
\text { National newspaper: "Alarm: Risk for several } \\
\text { programmes to be cancelled", "Can be } \\
\text { catastrophic", and "Probably the most severe } \\
\text { criticism ever raised in Swedish higher } \\
\text { education evaluation". The chancellor is quoted, } \\
\text { and the article was distributed via TT. }\end{array}$ \\
\hline $\begin{array}{l}\text { Virgo } \\
\text { Two evaluations: } \\
\text { Very high: } 1 \\
\text { High: } 1\end{array}$ & $\begin{array}{l}\text { "District nursing } \\
\text { programme at the } \\
\text { absolute national top elite } \\
\text { level" }\end{array}$ & $\begin{array}{l}\text { Regional newspaper: "The university gets the } \\
\text { highest grade". The vice chancellor is quoted } \\
\text { discussing the good quality and many students } \\
\text { applying for the programme } \\
\text { Local radio: Education at Virgo is highlighted as } \\
\text { a good example. }\end{array}$ \\
\hline $\begin{array}{l}\text { Pegasus } \\
\text { Seven } \\
\text { evaluations: } \\
\quad \text { High: } 1 \\
\text { Inadequate: } 6\end{array}$ & $\begin{array}{l}\text { "Questioned quality in } \\
\text { specialist nursing } \\
\text { programmes" }\end{array}$ & $\begin{array}{l}\text { Three regional newspapers: (1) "Nursing crisis } \\
\text { can get worse", with quotes from a Pegasus } \\
\text { representative saying it will work hard to rectify } \\
\text { the problems and is not worried - think it will } \\
\text { pass the follow-up. (2) "Inadequate education", } \\
\text { with quotes from a Pegasus representative } \\
\text { assuring it is taking the results seriously. (3) } \\
\text { "Major flaws in Pegasus nursing programmes" } \\
\text { from TT but with angling in headline and about } \\
\text { the end to the regional area and to Pegasus (like } \\
\text { the Orion article). }\end{array}$ \\
\hline
\end{tabular}

depending on. This finding is similar to a study on another Swedish agency, the Swedish Schools Inspectorate (Rönnberg et al. 2013). The study reported in this chapter highlighted how these central and perceived credible state actors chose to frame their press releases and communicate with the media. These attempted framings easily flow through and are not generally subjected to additional media scrutiny. The mission of independent media scrutiny was not highly pronounced in the anal- 
ysed material, and the media seldom reprocessed evaluation results data or highlighted alternative ways of interpreting them. This gives leeway to both successful pitching to the press and for opening up for bureaucratic branding activities.

\section{Bureaucratic Logic of Appropriateness in Agency Branding}

In balancing and adapting the bureaucratic logic to the format of the media logic, the agencies and, to some extent, the HEIs were seemingly successful in how they met and interacted with the (regional) media. The findings point to some instances where favourable bureaucratic branding of the HEI was amplified by supportive local media reporting, without the media asking for additional sources and/or information, such as in the Virgo hero story and, even if less pronounced, in the Pegasus case. But the pattern is not clear-cut and may depend on the HEIs' different roles and academic profiles. Virgo and Pegasus are both regional universities with important ties to the local and regional area.

The findings also point to an adapted form of packaging and to selling "bureaucratic" information, which make the mediation and translation from the agency/HEI to the media particularly smooth. The bureaucratic values and ideals function as an important "currency" in the packaging and selling of information via media. In fact, the bureaucratic logic of appropriateness is a part of the bureaucratic branding. It is a good media pitch, as it is perceived as credible and linked to perceptions enhancing its legitimacy. This is all managed via well-skilled communication offices in both the agencies and the HEIs. Based on these findings, we may be witnessing a "professionalisation" of public agency-media relations, including bureaucratic branding activities (cf. Christensen and Gornitzka 2018). Like the spread of managerialism, this study points to the important role played by a professionalised cadre of "bureau-branding" employees at universities and public agencies that are working to design, manage, and steer external and internal communications. These employees are professionally "pitching the press" under the legitimising shield of the bureaucratic logic.

\section{What Happened to Critical Debate?}

An important silence concerns the absence of critical debate on the evaluation framework's validity. Very little of the criticism and debate about the 2011-2014 EQA system (see the chapter "Hayek and the Red Tape: The Politics of Evaluation and Quality Assurance Reform - From Shortcut Governing to Policy Rerouting") was visible in this study. However, the fact that the empirical material does not cover the overall media discourse in general but rather has pinpointed certain HEIs and two evaluations in particular needs to be reiterated. Even so, this material demonstrated very few traces of the intense critical debate on the 2011-2014 EQA 
system. This debate seems to have been effectively silenced in the reporting on evaluation results when the system actually was in operation. The framework that produces these results is questioned in what appears to be "a parallel debate" - not intersecting with the reporting on these evaluations' actual results.

Journalists do not use the angle of the political debate and the criticised evaluation system design in these reports. The interviewed HEI representatives do not bring it up either, according to how they are cited in the analysed media materials. The HEIs and their representatives are not attempting to pitch the criticism of the system as a possible defence and/or counter argument when responding to individual programme evaluations' results. Largely, the approach taken when an HEI is judged inadequate is for HEI representatives to be submissive and to show compliance and willingness to adapt to the SHEA and improve but assume that they will rectify the situation and meet the standards, assuring people that work is already on its way - a calming message to the public. When objecting, HEI representatives may risk being judged as having something to hide, they may come across as unreceptive, and any critique can be turned against them and make the HEI look defensive, stiff, and unwilling to improve. In this way, the performative agenda is narrowing the space of what can be said.

\section{Finally}

This chapter empirically illuminated some of the processes in which high-stakes national evaluations, PR strategies from the HEIs, and the media logic meet and intertwine. It gave some empirical accounts on how processes of mediatisation are taking place in and through agencies and highlighted some important interdependencies that need to be critically discussed in relation to their possible constitutive effects (cf. Dahler-Larsen 2012). Not only is the existence of national EQA systems forming certain perceptions of what good higher education is "supposed to be" in this case, but the mediatisation of these evaluation results and central stakeholders' navigation of these processes are also important parts of these perception formations and the potential constitutive effects of quality assurance and other forms of evaluations. The way the media uncritically presents evaluation results from the EQAs may also contribute to the image of them as unproblematic and objective ways of measuring and controlling for "quality" in higher education.

Having outlined some of the mediated representations of actual evaluations conducted within the 2011-2014 EQA system, the next chapter discusses the period when the national agency and the HEIs prepared for the new, yet not formally decided upon, 2016 EQA system that was to replace the debated 2011-2014 EQA system. We will describe and analyse how the four case HEIs - Orion, Hercules, Virgo, and Pegasus - navigated, developed, and designed their own internal quality assurance systems. 


\section{References}

Academic Rights Watch. (2015). Bad news is no news? http://academicrightswatch.se/wp-content/ uploads/2015/04/Högskolornas-nyheter.pdf. Downloaded 8 Aug, 2016.

Altheide, D., \& Snow, R. P. (1979). Media logic. Beverly Hills: Sage.

Anderson, G. L. (2007). Media's impact on educational policies and practices: Political spectacle and social control. Peabody Journal of Education, 8(1), 103-120.

Bell, S., Hindmoor, A., \& Mols, F. (2010). Persuasion as governance: A state-centric relational perspective. Public Administration, 88(3), 851-870.

Christensen, T., \& Gornitzka, ̊̊. (2018). Reputation management in public agencies: The relevance of time, sector, audience, and tasks. Administration \& Society, OnlineFirst. https://doi. org/10.1177/0095399718771387.

Clarke, J. (2015). Inspection: Governing at a distance. In S. Grek \& J. Lindgren (Eds.), Governing by inspection (pp. 11-26). London: Routledge.

Crow, D. A., \& Lawlor, A. (2016). Media in the policy process: Using framing and narratives to understand policy influences. Review of Policy Research, 33(5), 472-491.

Dahler-Larsen, P. (2011). Evaluation society. Stanford: Stanford University Press.

Dahler-Larsen, P. (2012). Constitutive effects as a social accomplishment: A qualitative study of the political in testing. Education Inquiry, 3(2), 171-186.

Ekecrantz, T., \& Olsson, T. (1991). Så sant som det är sagt. Källor och konstruktioner i journalistiken. [As true as it is said. Sources and constructions in journalism]. Stockholm: SIM.

Englund, T. (1996). Utbildning som "public good” eller "private good"? In T. Englund (Ed.), Utbildningspolitiskt systemskifte? [A system shift in educational politics?]. Stockholm: HLS.

Ericson, M. (2014). Analys av Universitetskanslersämbetets utvärderingar av utbildningskvalitet år 2011-2014 [Analysis of The Swedish National Agency for Higher Education evaluations 2011-2014] (Slutrapport del A). Stockholm: KTH.

Fredriksson, M., \& Pallas, J. (2016). Much ado about media: Public relations in public agencies in the wake of managerialism. Public Relations Review, 42(4), 600-606.

Gewirtz, S., Dickson, M., \& Power, S. (2004). Unravelling a 'spun' policy: A case study of the constitutive role of 'spin' in the education policy process. Journal of Education Policy, 19(3), 321-342.

Government Bill. (2009/2010:149). En akademi i tiden - ökad frihet för universitet och högskolor [An Academy in line with its time]. Stockholm: Utbildningsdepartementet.

Grek, S., \& Lindgren, J. (Eds.). (2015). Governing by inspection. London: Routledge.

Hjarvard, S. (2013). The mediatization of culture and society. London: Routledge.

Karlsson, S., Fogelberg, K., Kettis, Å., Lindgren, S., Sandoff, M., \& Geschwind, L. (2014). Not just another evaluation: A comparative study of four educational quality projects at Swedish universities. Tertiary Education and Management, 20(3), 239-251.

Kettis, Å., \& Lindberg-Sand, Å. (2013). Kvalitetssystemets kval. En dialog från olika utgångspunkter [The qualms of evaluation systems. A dialogue from different viewpoints]. Högre Utbildning, 3(2), 139-149.

March, J., \& Olsen, J. P. (1989). Rediscovering institutions. New York: Free Press.

March, J., \& Olsen, J. P. (2006). The logic of appropriateness. In M. Moran, M. Rein, \& R. E. Goodin (Eds.), The Oxford handbook of public policy. Oxford: Oxford University Press.

Newman, J., \& Clarke, J. (2009). Publics, politics and power: Remaking the public in public services. London: Sage.

Peters, B. G. (1999). Institutional theory in political science. The 'new institutionalism'. London: Pinter.

Power, M. (1999). The audit society. Rituals of verification. Oxford: Oxford University Press.

Rawolle, S. (2010). Understanding the mediatisation of educational policy as practice. Critical Studies in Education, 51(1), 21-39. 
Rönnberg, L., Lindgren, J., \& Segerholm, C. (2013). In the public eye. Swedish school inspection and local newspapers: Exploring the audit-media relationship. Journal of Education Policy, 28(2), 178-197.

Segerholm, C., \& Hult, A. (2015). Manoeuvring the European Quality Landscape: The significance of ENQA policy in governing Swedish higher education. Paper presented at the European Conference for Educational research (ECER), Budapest 8-11 September, 2015.

SHEA. (2014a). Evaluation process 2011-2014 . http://www.uka.se/qualityassurance/standardeva luationprocess.4.4149f55713bbd917563800010219.html. Downloaded 22 Oct 2015.

SHEA. (2014b). En tredjedel av utbildningarna inom pedagogik ifrågasätts [One third of all programs in education is questioned]. Published October 1, 2014. Available at: http://news. cision.com/se/universitetskanslersambetet/r/en-tredjedel-av-utbildningarna-inom-pedagogikifragasatts,c9652604. Downloaded 18 May 2018.

SHEA. (2014c). Många utbildningar till specialistsjuksköterska ifrågasätts [Many proggrans in specialist nursing are questioned]. Published October 22, 2014. Available at http://news. cision.com/se/universitetskanslersambetet/r/manga-utbildningar-till-specialistsjukskoterskaifragasatts,c9664846. Downloaded 18 May 2018.

SHEA. (2015). Årsredovisning för Universitetskanslersämbetet 2014 [Annual report 2014]. Stockholm: Universitetskanslersämbetet.

SHEA. (2018). Hitta granskningsresultat $i$ Högskolekollen [Find evaluation results with the web-based tool Högskolekollen]. http://www.uka.se/om-oss/aktuel2015lt/intervjuer/201805-14-hitta-granskningsresultat-ihogskolekollen.html?utm_source=newsletter\&utm _ medium=email\&utm_campaign=Nyhetsbrev14maj18. Downloaded 15 May 2018.

Stake, R. E. (2006). Multiple case study analysis. New York: The Guilford Press.

Strömbäck, J. (2008). Four phases of mediatization: An analysis of the mediatization of politics. International Journal of Press/Politics, 13, 228-246.

Thomas, S. (2009). Newspapers on education policy: Constructing an authoritative public voice on education. In R. Fitzgerald \& W. Housley (Eds.), Media, policy and interaction (pp. 205-223). Farnham: Ashgate.

Thorbjørnsrud, K. (2015). Mediatization of public bureaucracies: Administrative versus political loyalty. Scandinavian Political Studies, 38(2), 179-197.

Tomlinson, M. (2017). Student perceptions of themselves as 'consumers' of higher education. British Journal of Sociology of Education, 38(4), 450-467.

Open Access This chapter is licensed under the terms of the Creative Commons Attribution 4.0 International License (http://creativecommons.org/licenses/by/4.0/), which permits use, sharing, adaptation, distribution and reproduction in any medium or format, as long as you give appropriate credit to the original author(s) and the source, provide a link to the Creative Commons license and indicate if changes were made.

The images or other third party material in this chapter are included in the chapter's Creative Commons license, unless indicated otherwise in a credit line to the material. If material is not included in the chapter's Creative Commons license and your intended use is not permitted by statutory regulation or exceeds the permitted use, you will need to obtain permission directly from the copyright holder.

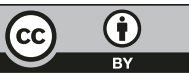




\title{
Enacting a National Reform Interval in Times of Uncertainty: Evaluation Gluttony Among the Willing
}

\author{
Joakim Lindgren, Linda Rönnberg, Agneta Hult, and Christina Segerholm
}

\begin{abstract}
This chapter offers an empirical illustration of the governing-evaluationknowledge nexus by pinpointing a particular situation, a pause between two national evaluation and quality assurance (EQA) reforms, while a new national system was being planned and prepared, but its final design was not yet decided upon. This situation - unusual in the Swedish higher education policy context - adds uncertainty to the situation and opens a potential space for policymakers and higher education institutions (HEIs) to navigate. We draw on interviews and documents collected from four HEIs during this reform interval. We analyse and discuss how the four institutions navigate, coordinate, mobilise, copy, and learn in a situation without a formal national EQA system in place but in which the wider higher education policy context is deeply infused with contemporary trends and international policies and ideas on quality assurance (QA). We found that context and institutional preconditions set their mark on the work undertaken during this interval. We also discerned tendencies of homogenisation and isomorphism. Finally, we highlight the tendency of further expansion of EQA activities.
\end{abstract}

\section{Introduction}

As we presented in the chapter "National Evaluation Systems", national requirements for HEIs to install and maintain internal quality assurance (IQA) work have been in place for around 25 years in Sweden. A number of national EQA systems have existed for evaluating quality in higher education during this period (cf. Segerholm et al. 2014). Previous chapters have shown how evaluative activities in

\footnotetext{
J. Lindgren · L. Rönnberg $(\bowtie)$

Department of Applied Educational Science, Umeå University, Umeå, Sweden e-mail: joakim.lindgren@umu.se; linda.ronnberg@umu.se
}

\author{
A. Hult · C. Segerholm \\ Department of Education, Umeå University, Umeå, Sweden \\ e-mail: agneta.hult@umu.se; christina.segerholm@umu.se
}

C. Segerholm et al. (eds.), The Governing-Evaluation-Knowledge Nexus, 
higher education have expanded into internal institutionally based and national EQA systems as an evolving evaluation machinery and that such means of governing are now an important part of policymaking and educational practice (Dahler-Larsen 2012; Westerheijden et al. 2007). We have also drawn attention to the European dimension of EQA. In the chapter "Europe in Sweden", we described how the European Association for Quality Assurance in Higher Education (ENQA), in cooperation with other European organisations for higher education, has promoted the development of national and local systems for higher education in Europe since the beginning of the millennium (Standards and Guidelines for Quality Assurance in European Higher Education Area (ESG) 2015). We also analysed the extensive national debate from 2014, when the Swedish agency was no longer accepted as a full member of ENQA because the 2011-2014 national EQA system was not considered as meeting the ENQA standards. Simultaneously, heavy criticism from academics and students in this strictly outcome-oriented national system led the government to terminate it in 2014 and appoint an investigator to look into these issues (Segerholm and Hult 2015). These events came together in a quite unusual situation as a break from the way reforms are normally prepared and implemented in Sweden - i.e. well in advance of implementation and following traditions of rational planning and social engineering, in which EQA systems have replaced one another sequentially with no evident "gaps" between systems (see the chapter "Governing By Evaluation: Setting The Scene", the section on the Swedish case). This situation, which we have characterised as a "national reform interval", signifies the time between the termination of the 2011-2014 national EQA system and the formal parliamentary decision in March 2016 to approve the 2016 EQA system. It also includes the work of the responsible agency, the Swedish Higher Education Authority (SHEA), until the final and elaborated upon system was presented in June 2016, which marked the end of the reform interval. Earlier, in March 2015, the government sent out a memorandum for referral to HEIs, students, and university teacher unions (Ministry of Education 2015). This government document gave the HEIs certain cues about what EQA reform to expect, should the parliament approve it.

This chapter offers an empirical illustration of governing by evaluation in higher education in this particular situation. This reform interval implied a pause or breaka situation of some uncertainty but also some expectations concerning the content of the forthcoming reform. This particular situation, we argue, opened a potential space for the HEIs: How would they navigate the situation without an explicit reform decision to relate to while receiving certain government cues about what would be waiting in the forthcoming reform? Would HEIs wait until the final parliamentary decision was made, or would they start to prepare and develop routines for QA in certain directions while remaining unsure whether they had to change it or not? The aim of this chapter is to illuminate the work during this reform interval at the national/state levels and among the HEIs. ${ }^{1}$ The following questions guide the chapter.

\footnotetext{
${ }^{1}$ The chapter draws on our joint empirical research reported and presented in the following conference papers: Lindgren and Rönnberg (2017), Segerholm et al. (2016), and Segerholm and Hult (2015).
} 
- What processes and work were undertaken in the national policymaking arena during the reform interval?

- What policy processes and practices (if any) do the HEIs have for handling and responding to the reform interval situation?

- How can such processes be understood in terms of education governing?

First, we outline our conceptualisation of the reform interval and how it can be theoretically understood as work, processes, and practices within the levels and domains of the state and HEIs. We will then address the first question to describe the reform interval and take a more elaborate look into the frame that the government gave in the above-mentioned 2015 memorandum. This section illustrates what the HEIs had to relate to during the reform interval. A section on the design, methods, and materials that we used in our empirical study of four HEIs will follow this illustration. We will then analyse the four cases, with a particular focus on their work with QA during the reform interval, before concluding with a discussion of our main findings.

\section{Mind the Gap: Conceptualising the National "Reform Interval"}

The notion of an interval indicates a time gap or an intervening time, a pause, or break in activity. To what extent is the present empirical case that we have labelled a "national reform interval" tangent to such notions? What evaluative activities of the state were paused (and what activities were not)? What aspects of work with the design, development, and enactment of IQA systems could be carried out in HEIs without detailed information about the standards against which it would be assessed? Did the HEIs respond differently to the lack detailed information? Did a space, room for manoeuvring that entails a condition for freedom and autonomy, open between two objects (policies)? Perhaps such an interval is not something out of the ordinary but instead is a rather common situation in public administration. If a new policy proposal is put "on hold" until it is enacted legally, the educational sector might expect that the temporary proposal will likely later be enacted as legislation, and, in that case, the situation would not be that extraordinary. In addition, European standards in the form of the ESG were firmly in place, offering guidance for Swedish HEIs, during the interval (Grifoll et al. 2012). Here, notions of "embeddedness" (Jacobsson et al. 2015) and the intertwined relationships between state agencies and international organisations are crucial.

We suggest that a reform interval is a general conditional situation of uncertainty - a rather common, if perhaps intensified, situation. Moreover - as Jacobsson et al. (2015) noted - the values of professionalism and mutual trust typically characterise Swedish state governance. Governing in the form of "micro-steering" can thus rely on subtle and informal means without giving the bureaucracy extensive and detailed guidance. In this case, an interval may imply "intensification" and reac- 
tions to uncertainty that raise empirical questions. Here, anticipation and cue giving have been used to explain how agency staff predict or second-guess political intentions and act on these hunches (Jacobsson et al. 2015).

If activities - such as the design, development, and enactment of IQA systems depend on detailed prescriptions, HEIs could choose to await such information. If the SHEA will externally evaluate them in a certain way, the HEIs may well await such evaluation criteria and then design their IQA systems to target such demands. The interval is an absence of a national policy, with much uncertainty about future policies along with a strategic incentive to "wait". Anticipatory behaviour is associated with risk (Jacobsson et al. 2015), and this in turn raises important analytical questions, such as those regarding how evaluation-making devices and arrangements function in the absence of stated and formal national policies. In other words, does friction, delays, or "loose-coupling" exist between policy and educational management?

The reform interval provided us with opportunities to empirically study issues of governing in the making. Governing, as we noted earlier in this book, includes processes in which several instances and actors are involved in forms of work including interpreting, negotiating, translating, and enacting policy (Clarke 2015). The stress on the actual work of governing and "doing" policy is arguably also consistent with the concept "enactment" (cf. Ball et al. 2012) in processes of policy interpretation and translation. Translation, as Latour (2005) pointed out, involves processes in which all actors and artefacts mutually transform and are transformed by the environment that they engage in. In this context, we are particularly interested in questions about whether - and, if so, how - enactment during the interval produces "irreversible interactions", i.e. enrols durable changes in social and material elements related to core activities within HEIs.

Our starting point is that translations of QA appear in "different but similar settings, where local resources, material and human, and diffuse sets of discourses and values are deployed in complex and hybrid processes of enactment" (Ball et al. 2012, p. 6). This means that the local context is of importance in understanding policy processes and governing during the interval. The overall characteristics of the Swedish political-administrative system, which manifested in the recent EQA reform processes that we analysed in the chapter "Hayek and the Red Tape: The Politics of Evaluation and Quality Assurance Reform - From Shortcut Governing to Policy Rerouting", include evident attempts to produce and establish policy through dialogue. This makes us devote particular attention to the inherent complexities of governing, given that various actors formulate policy at various levels. Complexity, however, does not contravene with the fact that many Swedish HEIs - at least on the surface level - appear quite similar: They appear as well-integrated organisations with modern, systematic, and thorough practices in terms of routines, strategies, and documentation that aim to enhance the quality of research, education, and cooperation with the surrounding society.

Acknowledging such similarities, we seek to explore how forms of internal HEI work on QA are enacted and evolve through processes of cooperation, imitation, editing, or as fashion (Sahlin and Wedlin 2008). Isomorphism (DiMaggio and Powell 1983) offers a classic attempt to analyse aspects of such processes in terms 
of three mechanisms: for example, coercive isomorphism, which stems from external political pressure from national and international policies and organisations in this case. On the other hand, mimetic isomorphism emphasises organisational responses to uncertainty. This leads to the assertion that if the HEIs experience the studied reform interval as uncertain, they might respond with mimicry. The final mechanism, normative isomorphism, relates to professionalisation. In this context, we are interested in the work, knowledge, and networks of key actors at the HEIs and the extent to which such factors produce relative homogeneity within the sector in the enactment of a national reform interval concerning EQA. Isomorphism in turn draws our attention to questions of rationality. As DiMaggio and Powell (1983) noted, the adoption of new (fashionable) ideas might provide legitimacy rather than improving actual performance, and not all ideas will be rational for all kinds of organisations.

We draw on these theoretical resources to explore policy processes and practices during the reform interval. During the interval, little was known about whether the new EQA system would lead to the further expansion of evaluative activities or whether an eventual expansion would produce better-functioning HEIs. This chapter is a contribution to a discussion on these challenging questions. Next, we turn to the processes at the national level, including the work of government; an appointed single-member commission's efforts in outlining a new EQA system; and the SHEA's task in finalising the system's design.

\section{The Reform Interval: The Government's Work Towards a Parliament Decision}

As described in previous chapters, the centre-right coalition government - in what we have labelled a fast-paced and "shortcut" style - decided upon and implemented the 2011-2014 EQA system that preceded the reform interval (cf. the chapter "Hayek and the Red Tape: The Politics of Evaluation and Quality Assurance Reform - From Shortcut Governing to Policy Rerouting"). This was done despite early and heavy criticism of its outcome-based orientation and lack of methodological rigour. This was, as we also noted earlier, a system that the ENQA criticised because it did not live up to the Standards and Guidelines for Quality Assurance in the European Higher Education Area (ESG) (2015) and ENQA (2009). The ENQA review concluded that the Swedish system failed since it did not evaluate HEIs' IQA system and did not give recommendations for improvement. Also, the national agency responsible for the QA could not be considered independent "due to the extent to which their procedures and methods, as well as overall aims and objectives have been dictated by Government" (SNAHE 2012, p. 23).

In 2013, the centre-right government decided to terminate the 2011-2014 EQA system. In these discussions, the ENQA membership was central in the arguments for terminating that EQA system and developing a new one (Segerholm and Hult 2015). The government commissioned the SHEA to develop such a revised system 
in 2013, but, in mid-2014, the agency received new directions from the government. At that point, the government commissioned an individual investigator, Professor Harriet Wallberg Henriksson (later director general of the SHEA), to propose a framework for a new national EQA system that would be founded on the following basic principles that the government set forth.

- The system should be cohesive and include the HEIs' internal QA and SHEA's external audits.

- The system should control students' learning (outcomes).

- The system should improve quality and provide HEIs with incentives and guidance.

- The roles of working life (relevance and employability) and working-life representatives should be more thoroughly included in audits.

- The role of students should be clearer.

- European principles on QA should be considered.

- The system should include sanctions, with possibility of revoking licenses for issuing student degrees.

- The system should consider the autonomy of HEIs and be transparent and explicit (Ministry of Education 2015, p. 4).

The government also directed the investigator to confer with the HEIs, the SHEA, students, and working-life representatives. The investigator's report was eventually delivered to the Ministry of Education in December 2014, and, based on that, the new Social Democratic-Green Party coalition government (in office after the 2014 September elections) crafted a memorandum. It was published in March 2015, and it set the overall frame for a new national EQA system (Ministry of Education 2015). In the memorandum, the importance of paying attention to the ESG - along with the need to align the new EQA system with the Higher Education Act and with the requirements for student degrees, as specified in the Higher Education Ordinance - was emphasised on several occasions. The new EQA system was to include the following:

- Accreditation for rewarding degrees and certificates

- Evaluation of the IQA systems at the universities

- Evaluation of a sample of bachelor-, master-, and PhD-level study programmes, foremost aiming to control the adherence to the Higher Education Act and the Higher Education Ordinance and to contribute to improving quality

- Thematic evaluations - e.g. widened recruitment of students, internationalisation, and gender equality (Ministry of Education 2015, p. 3)

The memorandum proposed that quality should be assessed in terms of student attainment and performance, but a description of the preconditions and processes that influenced would complement the result. Furthermore, the SHEA would be responsible for developing and implementing the new EQA system, based on the government's judgement, laws, ordinances, and principles for QA, which is in line with the Bologna Process. The starting point for the memorandum was that all 
higher education programmes should be evaluated through the universities' IQA systems and the SHEA's evaluations of them. In the memorandum, it was also specified that SHEA, as in previous national EQA systems, should appoint an expert panel that should assess the self-evaluations that the HEIs handed in and prepared. The SHEA was supposed to later elaborate upon and specify the information and aspects of quality that should be included. Interviews were also required to be carried out with representatives for the HEIs, including teachers and students. The expert panel was supposed to document its assessment in a report that would form the basis for the SHEA's judgement and decision. The memorandum also stated that this is an internationally established method for QA in higher education. It also said that follow-ups after the assessment can promote quality - as, for example, HEIs learn from each other and from observations from the expert panels.

In carrying out the government mandate to further develop the design for the new EQA system's details, the SHEA organised several hearings with stakeholder groups during 2015. These groups included teacher and student unions, vice chancellor organisations, and organisations for the private market and public sector. However, the parliament was to make the final decision about the system, making the HEIs and SHEA insecure about what to actually expect in the end. In December 2015, the Ministry of Education had processed all incoming referrals on the memorandum, and they made very few revisions before sending their proposal to the Parliamentary Standing Committee on Education, which finally advised the parliament to endorse it. The decision was made in March 2016, with some amendments (Government Petition 2015/2016:76; Parliamentary Decision 2015/2016:155). After this, the SHEA continued to work on the details and the additional requirements on the system that the parliament had decided upon. During spring 2016, the SHEA had regular meetings and dialogues about its work to design the forthcoming EQA system with HEIs, national and international reference groups, and groups representing stakeholders. The agency also organised conferences among other things to present information and get acceptance for their proposed ideas. In June 2016, the SHEA presented their final and detailed design of the EQA system and reported this work to the Ministry of Education in early October 2016.

As the above account demonstrates, the reform interval was not by any means an interruption in policy work at the national level. On the contrary, the politicians, the public commission, and the SHEA carried out extensive work in designing and developing the new EQA system, and this work also fed into the work of other state agencies and nongovernmental organisations. Actors and reference groups from within academia, including all HEIs and student union organisations; labour market actors, including teacher unions; employee organisations; and interest groups, were mobilised in rounds of meetings and hearings.

In the next section, we direct our attention to the processes and practices enacted within the HEIs during the interval. Before we enter this exploration, we will say a few words about the empirical case study reported in this chapter and briefly touch on its design, methods, and materials. 


\section{Four Cases: Methods and Materials}

The study was designed as a multiple case study (Stake 2006). Four HEIs with varying ages, sizes, specialisations, and geographical locations were selected. They also represented different aggregated outcomes from the 2011 to 2014 system evaluations of study programmes. (See Table 1)

This design arguably fits well with the intended approach for understanding policy enactment at HEI level (Ball et al. 2012), since it gives a voice to HEIs that are located in quite different contexts and have different institutional set-ups. Our selected cases include one old university with a comprehensive number of faculties and academic and professional programmes and courses; one new small university college with one faculty and mainly professional programmes; one well-established specialised university with one faculty and mainly professional programmes; and one medium-sized new university with two faculties and professional and academic programmes and courses. The four HEIs are geographically dispersed, and, in the latest national quality evaluation that the SHEA carried out, they received different results - ranging from not good to very good (only one university in Sweden was assessed as extremely good) (Ericson 2014).

We did a total of 16 individual interviews, mainly during spring 2015 and spring 2016. We interviewed the vice chancellors; central officers who were responsible for IQA at the HEIs, including deans and/or other officers at the faculty level; and a limited sample of those at the department level who were responsible for IQA. We asked the informants about whether and how the HEI prepared for the expected national reform, how they perceived difficulties with preparation work, and how they envisioned and designed a good IQA policy and practice, and we asked more generally about quality and accountability in the HEI. We also collected and analysed policy documents of QA work at different levels in the HEIs, the four vice chancellors' blogs, website information, and other types of written materials from the HEIs.

Table 1 Summary of cases in terms of size, age, profile, and education quality

\begin{tabular}{|c|c|c|c|c|}
\hline HEI & $\begin{array}{l}\text { Relative size } \\
\text { (1-4 from large } \\
\text { to small) }\end{array}$ & $\begin{array}{l}\text { Relative age } \\
(1-4 \text { from old } \\
\text { to new })\end{array}$ & $\begin{array}{l}\text { Profile/ } \\
\text { specialisation }\end{array}$ & $\begin{array}{l}\text { Outcome } 2011-2014 \text { EQA } \\
\text { evaluation }^{\text {a }} \text { (1-4 from high } \\
\text { to low grades) }\end{array}$ \\
\hline $\begin{array}{l}\text { Pegasus } \\
\text { University }\end{array}$ & 2 & 4 & Broad/regional & 4 \\
\hline $\begin{array}{l}\text { Virgo } \\
\text { University } \\
\text { college }\end{array}$ & 4 & 3 & $\begin{array}{l}\text { Special/ } \\
\text { regional }\end{array}$ & 2 \\
\hline $\begin{array}{l}\text { Orion } \\
\text { University }\end{array}$ & 1 & 1 & $\begin{array}{l}\text { Broad/ } \\
\text { traditional }\end{array}$ & 1 \\
\hline $\begin{array}{l}\text { Hercules } \\
\text { University }\end{array}$ & 3 & 2 & Special/elite & 3 \\
\hline
\end{tabular}

anternal ranking from 1 to 4 based on results from quality evaluations by the SNAHE and the SHEA between 2011 and 2014 as presented by Ericson (2014) 
We heuristically used the idea of enactment in organising and analysing the material. We concentrated on the questions about what, how, and who and context questions concerning the work with the HEIs' policy and practices during the reform interval. We posed the following questions about the collected material. What kinds of activities have taken place at the HEIs? What actors have been central as driving forces? What kinds of processes were undertaken to justify and legitimise the internal work with QA? What cooperation and/or exchange of experiences of IQA with other HEIs took place, if any? Did any resistance take place? What parts of the organisation are mobilised in IQA work?

\section{The Reform Interval: IQA Work in Four Higher Education Institutions}

In the following, we begin by describing some of the main characteristics of the cases (with some restrictions to respect confidentiality) before we move on to discuss their activities concerning IQA during the reform interval.

\section{Pegasus}

Pegasus is a medium-sized and young regional university. Despite being a comparably small university by Swedish standards, it nevertheless has a quite broad panoply of study programmes and courses - including humanities, information technology, social sciences, behavioural sciences, media, teacher education, natural sciences, health education, science, and technology. Distance education and interdisciplinary education are two cornerstones at Pegasus, and it seeks ways to cooperate with the local community to promote regional development. Pegasus is organised as a line management system with a governing board, vice chancellor, pro-vice chancellor, and two faculty boards. In the 2011-2014 EQA system targeting study programmes, however, Pegasus was one of the most heavily criticised universities. Almost $50 \%$ of the programmes or courses were judged as having "insufficient quality", whereas few programmes received the grade "very high quality".

Overall, Pegasus took a quite proactive strategy during the reform interval. Pegasus and two other HEIs decided to make a joint effort to construct a peer review system of assessments for collegial education quality. This endeavour was intended to build on ongoing cooperation that had involved aspects of education and management, though not yet in the area of education evaluation and assessments. Pegasus formed a task force comprising the vice chancellors and additional highlevel management in early 2015 to investigate whether - and, if so, how - a collaborative system of assessing education quality could be designed and implemented. The three collaborating HEIs wanted to organise quality assessments 
of study programmes and courses based on the overall assumption that collaborating, developing, and exchanging knowledge and experience between the three HEIs would have potential benefits.

These joint education assessments (henceforth "JEAs") should however not be seen in isolation. The JEAs are considered one part of a wider and more encompassing IQA system at Pegasus, which means that the overall organisation of QA includes additional dimensions apart from the JEAs. At Pegasus, JEAs are considered activities under the heading "quality evaluation". The other three main headings for the IQA system are "pre-emptive quality work", "continuous quality work", and "quality follow-up" - aiming to cover, monitor, and assess the prerequisites, processes, and results of the education that Pegasus offers. The JEAs employ a specified set of evaluation criteria, all of which are clearly and explicitly related to the Standards and Guidelines for Quality Assurance in European Higher Education Area (ESG) (2015). In addition, each of the universities (or the responsible faculty) has the opportunity to add complementary criteria or questions to the evaluation matrix of the specific round of evaluation. The JEAs were piloted in 2016 and evaluated in 2017 before their more detailed design was finally decided upon.

The JEA task force met on 6 occasions and organised 2 larger seminars with around 40 participants from the 3 HEIs. Three sub-groups were also formed, and they looked at possible clustering for academic subjects, administrative implementation, and internal and external communication. The JEAs were presented in 2015 at a national higher education conference in which questions of legitimacy and ways to mobilise staff support were emphasised.

When introducing the JEA system at Pegasus, the vice chancellor emphasised that highlighting the ownership issue - i.e. that the HEIs themselves were initiating and implementing the JEAs and that it was not a system imposed "from above" via the SHEA - was important. Ownership was framed in emotional terms: as a "victory". By framing the JEAs in this way, the management hoped to bring about acceptance and willingness to work with the JEAs and the overall IQA practices to which they belonged. Whereas the work within the JEAs was organised with collegial representation, the implementation of the JEAs appeared to run along rather-traditional paths from the top of the organisation down to the bottom; decisions were initiated and taken by the management, processed by the quality group, and then channelled to faculties that were "activated" (Pegasus 2015).

\section{Virgo}

Virgo is a small and rather young university college. According to the Virgo website, strategic specialisation and close cooperation with international and local companies and the public sector are its significant features. Research, it is claimed on the Virgo website, provides knowledge, innovations, ideas, and a qualified workforce in cooperation with external stakeholders. In addition, educational activities are organised to facilitate cooperation through mentorship, guest lectures, advisory 
boards, and students' written degree projects. Despite its specialisation, Virgo offers programmes and courses in subjects related to informatics, engineering, business, health, and education. This HEI is also organised as a line management system with a governing board, vice chancellor, and pro-vice chancellor. Virgo did well in the quality evaluations in 2011-2014. Apparently, this "success" has built organisational self-esteem and confidence that its study programmes, courses, and IQA system are of high quality. It has one faculty board and the dean is responsible for the IQA. The delegation of authority is built on the principle that the faculty board makes propositions that relate to systems of follow-up and evaluation and propositions for decisions regarding QA and quality development.

The former IQA system at Virgo was described in a quality policy dated 2011, and this description was still on the website in 2016. In other words, Virgo was not in a hurry to reform its IQA system. Furthermore, it was concerned neither about cooperation nor with looking into how other HEIs built their IQA systems, which might be interpreted as manifestations of the above-mentioned confidence. However, during 2015, an inventory was performed for polices, directions, guidelines, and routines at all levels of the institution to make sure that they had in place a coherent system without any gaps. Besides the dean, the representatives for the disciplines and study programmes are important in developing a new IQA system. The faculty board arranged a couple of seminars in 2015 to act on identified absences; for example, one seminar was intended to make explicit the mandate and responsibility for leading roles - such as the ones responsible for study programmes, research groups, disciplines, and doctoral studies. In these seminars' PowerPoint presentations, the success of Virgo in relation to all other Swedish HEIs in the last round of the national evaluations was highlighted. The faculty's message to the responsible actors in the departments and programmes was to not settle down because "the hard part is to maintain high quality ... and that is why a systematic and continuous development- and QA work is called for" (Virgo 2015, emphasis added).

Virgo was aiming at an IQA system that involved proactive and continuous follow-ups as close to educational practice as possible. The idea was to make eventual quality problems visible at an early stage to give support to correct or finishing courses or programmes. It was a system that was designed to permeate a cyclic process: forming a discipline, programme, or course; planning and carrying it through; continuously following it up (formative); conducting regular (summative) evaluations of it; and winding it up. This process had clearly defined roles and mandates, work models, and functions for coordination. It also comprised distinct routines, infrastructure, administration, support systems, key figures, management information support, channels for information and communication, competence provisions, and processes designed for organisational learning. It was a system that was designed to "build a culture of quality" by strengthening the cooperation between the academy and administration. It was aligned with the ESG and oriented towards national goals. It also contained alumni and programme inquiries, selfevaluations, and additional statistical figures. However, in the material, the risk of "unnecessary bureaucracy" was highlighted as an important challenge. 


\section{Orion}

Orion is a large, old, comprehensive university, with almost all faculties represented (medicine, law, social science, science, and theology). On its website, the university stresses its ambition to lead the world in research and education. Orion has a line management system with a governing board, a vice chancellor, a pro-vice chancellor, a small number of deputy vice chancellors, combined to a certain extent with a collegial management system. The internal quality work is assigned to a special central group that works with issues of evaluation and education quality, and this has been the case for many decades. The formal responsibility for decision-making concerning IQA is with the faculty boards. In the national quality evaluation of higher education 2011-2014, Orion did very well, as did most of the old and wellestablished universities (Ericson 2014).

Also, representatives (active researchers/teachers) from all faculties and student representatives compose a central committee. The intent of the committee is to support faculties and departments in their work with quality and give advice to the vice chancellor in such matters. Orion had an elaborate programme that was based on academic values and virtues for internal work with quality issues in education, research, and extramural activities in place since 2002 and was revised in 2008. This programme responded to the university's internal demands for quality and was combined with external demands for quality in education to emphasise accountability.

Shortly after the government memorandum was presented in spring 2015, a task force comprising a chairperson, two representatives from the faculties, three student representatives, and three experts from Orion's central administration, was selected by the vice chancellor. This group started to map activities already in existence in the faculties and tried to identify what was needed so that they could live up to the expectations expressed in the government memorandum. From the very beginning, the group was determined that Orion's new IQA system needed to be minimalistic, allowing the faculties to add what they found important and develop slightly different models - depending on their variations of disciplinary and scientific traditions - and directions for the study programmes. The intent was for the new system to be as little of an inconvenience as possible but be adapted to the national system proposed in the government memorandum.

The task force met continuously during 2015 and spent considerable time in presenting their work to internal groups - such as the vice chancellor and head management group, all faculty boards, heads of departments, and student unions. In so doing, their ambition was to collect ideas for improving the evolving design of Orion's IQA system and provide an opportunity for criticism to be channelled. This process aimed at legitimising the new system and at making the implementation smooth. The task force faced the challenge of designing an IQA system that did not add requirements of collecting, documenting, and reporting information. A small international advisory group was formed for support and critical comments during this process (Orion 2016). The task force's final proposal was circulated within the university during spring 2016. 
Orion's new IQA system includes evaluations of study programmes and courses that should be undertaken systematically at least every 6th year by "at a minimum two external assessors and at a minimum one colleague from a different faculty" (Orion 2016, p. 6). All evaluations within the new system should take the Higher Education Act, the Higher Education Ordinance, and the ESG as a starting point. The evaluation process includes a self-evaluation, external review from assessors and colleagues (peer review), and the involvement of teachers and students in the entire evaluation process, and it should lead to an evaluation report that includes the central results from the peers, the self-evaluation report, and suggestions for what measures need to be taken (Orion 2016). The faculty boards should summarise what needs to be done, be responsible for follow-ups within a year, and organise public access to all evaluations.

The new system was met with overall positive reactions among staff. Two observations are important. First, knowledge about and involvement in the new IQA system were not distributed within the whole university. Also, resources for the new QA system were considered a problem, even by the task force:

Of course, there are many who say "how is this supposed to work? How much time are we supposed to put down on this?" (...) and that is perhaps people who do not think evaluations are that important, rather an unnecessary evil. (Orion faculty representative 2016)

The vice chancellor awaited detailed demands from the SHEA before making the final decision on IQA system's design. In the meantime, preparatory work was done: "Either way, the vice chancellor will most probably announce resources for a small number of pilot evaluations before that, as part of Orion's preparations" (Central task force informant 2016).

\section{Hercules}

Hercules is one of Sweden's specialised HEIs with university status. It is regarded as a distinguished and internationally recognised educational and research institution. It is a relatively small university with a university board that has overall responsibility. Special boards - similar to faculties - for education, research, and graduate education are at the level below this. The university board has an external chairperson and a vice chancellor, and the deans of the special boards are the toplevel managers of the university.

The board of education makes policy decisions regarding EQA for the university. A special unit is responsible for developing specific assessment instruments, and teachers and programme managers are responsible for collecting information required for the IQA system. Over the years, Hercules has done relatively well in quality evaluations but has also received criticism.

Around 2010, Hercules developed a dedicated strategy and took action to strengthen its work with QA because one of the university's major study programmes had failed in the national quality evaluations. The university internally mobilised the board, deans, and heads of the departments that were involved in the criticised 
programme. Furthermore, an external quality expert was appointed with the mission of reviewing the university's QA system, including the internal evaluations of undergraduate programmes conducted before the national quality evaluation. One recommendation was to develop a clearer system for QA that would strengthen the overall accountability structure. Prior to the introduction of the SHEA's new model for the quality assessment of HEIs, the university's infrastructure for IQA and concrete methods for evaluating study programmes and courses were also gradually tightened. To make the programme managers, heads of departments, teachers, and students aware of the evaluation forms to be used, the university established communication channels via the intranet, the established framework of decisionmaking. In addition, the IQA was further adapted to the ESG. Surveys and instructions for quality assessments are found in the indicators for assessing the ESG's quality. Furthermore, training and curricula were deliberately and systematically adapted to the wording of the Higher Education Act and the Higher Education Ordinance.

Hercules allocated resources to maintain and develop IQA, while work was also performed at several levels as part of the mission that the departments have no resources for completing. In efforts to develop and improve the IQA, Hercules cooperated with several other HEIs in a network. The network aims to share experiences and compare ideas and ways to implement QA without any binding joint decisions.

Hercules's IQA is a cyclic evaluation model that is based on national and internal learning outcomes, and it evaluates, documents, and thus clarifies information on processes and preconditions for goal attainment. It includes student surveys, specific evaluations, thematic evaluations, exit polls, alumni surveys, course evaluations, working-life surveys, and additional evaluations.

\section{Policy Enactments in the Reform Interval}

The case descriptions above have offered empirical illustrations of policy processes and practices during a reform interval in four HEIs. Earlier, we discussed the national and governmental policy work that was taking place at this point. Our study indicates that the enactment of EQA policy is rather lively at the national level, within the four HEIs and across the entire higher education sector. It is also clear that contexts and conditions matter regarding how the four HEIs tackled this interval between two national EQA systems, resulting in a period of uncertainty and preparation that took on different forms across the studied cases. Processes of developing and revising existing IQA policies and practices were initiated and developed differently in the four cases in relation to their respective QA histories - that is, both in relation to what they had done and in relation to how they had been assessed by the SHEA in the 2011-2014 national EQA system. Depending on their size, they also could use very different economic resources for QA-related activities. Orion has had a special unit for this purpose for decades, whereas Virgo - being a small and young institution - had to rely on the dean tackling this job. We note that the four HEIs started 
their IQA work at different times during the reform interval; some were more proactive and initiated internal work quite early on and did so before the government decision and even before formal intentions and written directions were formulated (Pegasus, Orion), and others waited a bit longer (Hercules, Virgo).

This means that some of the difference in speed, intensity, and comprehensiveness of the work with preparing IQA systems between our cases can be understood by relating those activities to the contexts and characteristics of the individual HEIs. We approached the analysed work of governing and of policy in term of enactment (Ball et al. 2012). We discerned that the enactments during the reform interval were numerous and varied, and each case had its own IQA story to tell. At the same time, there are apparent similarities across the analysed cases. Despite the uncertainty during the reform interval, HEIs tended to take (some form of) action: They have all developed IQA policies. They have been invited to participate in the state commission of inquiry to produce a new national system in a process of dialogue, consensus seeking, and decision-making. The HEIs have distributed tasks and responsibilities in the form of roles and task forces; have arranged meetings; have produced documents, including external and internal evaluations, policies, plans, directives, models, PowerPoint presentations, and memorandums; and have organised activities (seminars, hearings, mail dispatches, blogs, and other means of information) to anchor and get support and approval for their planned and evolving IQA systems, be it in various ways.

The HEIs' work with IQA design was clearly a top-down affair, and procedures were initiated and steered from the organisational centre to its peripheries (if it ever got that far). Top-level administrators and vice chancellors initiated and mobilised the work, and this was largely not a matter for staff on the ground. Another signifying trait in these processes is the perceived need and talk about dialogue and trust, as well as avoiding unnecessary bureaucracy. The rhetoric of enhancement (see Saunders 2014) has been embraced - quite explicitly in many cases - and this conceptualisation of quality and improvement is voiced and embraced in the HEI processes. In many ways, quality is perceived as a constant, ongoing, and nonseparable part of everyday workings. However, somewhat paradoxically, and as we will return to below, processes and designs are firmly steered from the top down.

\section{Governing “Between” Reforms: Anticipation and Action}

In this final section, we will discuss the reform interval in terms of governing. One first observation is that to the extent that a national policy is "absent", European input in the form of ESG functions as apparently naturalised sources of guidance. As one of our informants said:

We meet each other. It is great. The last two meetings have been about what do you do and how do you handle this, have you started to adjust [to the forthcoming but not yet approved external demands, our note], how do you do it? We give each other advice. Some of us have reviewed how the present IQA systems comply with ESG and then shared this with the rest of us. And that is great. (Hercules, Faculty representative 1) 
This informant voices a striking similarity across cases, namely, that there are important homogenising forces serving as a cue giver during this reform interval: the ESG. All HEIs not only have explicit and visible references to these standards but the standards are also explicitly communicated and disseminated externally between HEIs and within them. In November 2015, the agency SHEA published a translated version of the ESG in Swedish, and in our reading of the HEI policy documents, we clearly discern how this has moved into the HEIs' vocabulary. On the one hand, the act of translation signifies the importance attributed to this document on a national level, but the informants in our data also seem familiar with the English version of the ESG and assigned them central roles in their internal IQA work before this translated version was published.

HEIs are thus "embedded" within the European policy community, where the ENQA offers "norms and directives which require domestic compliance at the very least consideration" (Jacobsson et al. 2015, p. 2). It is also notable how actors within the higher education sector engage in information-seeking and brokering activities where they pick up messages provided by the political level or the SHEA. Thus, as noted by Jacobsson and colleagues (2015, p. 4) "micro-steering in the shape of 'steers' and other subtle signals or even anticipated reactions among the civil servants allows the core executive to control the bureaucracy".

\section{A Temporary Motor Failure in the Evaluation Machinery?}

We would also like to return to an idea introduced in the chapter "National Evaluation Systems" - the ideal typical notion of evolving "evaluation machinery" in higher education. There are a number of observations that we find interesting in this context. One of them regards "permanence", which is one important characteristic of evaluation machines (Leeuw and Furubo 2008; Dahler-Larsen 2012). The findings presented in this chapter suggest that the institutionalisation of an evaluation machinery through, for instance, the promotion of evaluation culture within the HEI sector make the machinery sturdy in case of temporary motor failure. HEIs take on evaluative work as a form of decentralised spare engines that secure the permanence of the evaluative activities. Permanence during the interval is secured by other characteristics of the machinery. Notably, modes of organisational responsibility have been installed in HEI organisations and in the minds of certain key actors working within the evaluation field, that is, "evaluators" that are working within and between organisations rather than external to them. This group, which we already have introduced in this book as "qualocrats", can be seen as the offspring of a "marriage between administration and evaluation" (Leeuw and Furubo 2008, p. 165) and is most likely an important reason that HEIs responses to the reform interval are so similar. This group of actors carries and possesses certain knowledge in and of EQA in higher education, which is brokered and promoted, and moves in the wake of meetings to initiate cooperation across HEIs, as well as to and from the policymaking arena, the ministry, and the political administration. 


\section{Understanding Governing in the Reform Interval: Standardisation and Homogenisation}

The enactments during the interval and the similarities that we have identified seem to evolve through such cooperation and exchange of experience of IQA work or what DiMaggio and Powell (1983) label normative isomorphism. Here, Virgo turns out to be an exception, as it is quite self-sufficient and exposes a sense of selfesteem due to their good turn out in the previous national quality evaluations, as we understand it. Another similar feature is the fairly top-down-oriented strategies all four HEIs use in how they have organised the work in developing their IQA systems. In a Swedish context, this is interesting because the so-called autonomy reform from 2010 gave way to a legal framework, meaning that the HEIs can organise their delegation of authority and formal internal decision-making as they please with the requirement that there are scientifically competent persons and students represented in these instances. In all our cases, the delegation of authority when concerning EQA rested with the faculty (scientifically competent instance).

However, the IQA work was steered and governed from the centre and top. As far as we can tell, whether the preparations reached out to the departments and to the "street level" of the HEIs is questionable. This behaviour, where central management at the HEIs takes the helm, may be ascribed to the uncertainty felt during the reform interval, similarly to what DiMaggio and Powell (1983) call mimetic isomorphism. In times of uncertainty, this conceptual explanation suggests that central management overtakes responsibility from the more collegial instances to achieve some unified policy direction. We suggest that this is perhaps also a question of trust, where in Sweden trust in collegial responsibility within the HEIs seems to be presently decreasing (SOU 2015:92). This is also shown by the move in several HEIs to so-called line management systems (Sørensen et al. 2015, p. 6). Line management systems, where the decision-making power rests with formal leaders (not necessary scientifically trained) in the organisation, have evolved as a fashion in HEIs in Sweden (Sahlin and Wedlin 2008). Issues of quality in research and education, traditionally a responsibility for faculty and colleagues (researchers and teachers), are increasingly becoming the responsibility of managers (of an organisation and the economy) and quality and evaluation experts (Forsell and Ivarsson Westberg 2016; Hall 2012). In the chapters "Re-launching National Evaluation and Quality Assurance: Governing by Piloting" and "Evaluation Machinery, Qualocrats, and the Seemingly Inevitable Problem of Expansion", we return to the issue of an emerging cadre of "qualocrats" who are doing EQA work in Swedish higher education.

There are also some striking similarities in our cases when it comes to how parts of the IQA systems are to be carried out, where the internationally common model of external reviewers ${ }^{2}$ is to be used as well as that of so-called self-evaluations. It is

\footnotetext{
${ }^{2}$ External reviewers may include peers (like in peer reviews, the collegial way of assessing the quality of scientific work). In the Swedish case, "external" refers to a HEI external group of peers, students, and representatives from other areas of society like employers.
} 
hard to say if this is an imitation of an international discourse of evaluation in higher education, an imitation of earlier Swedish national systems, or an imitation of fellow HEIs in Sweden. It may well be more like a fashion, since this model is applied in so many HEIs globally. If the stress on the ESG - also visible in all our cases - is taken into account, Sweden and, as a result, the HEIs apparently feel coerced to accommodate to those in one way or another.

Another similarity is the conflict between a wish to develop and design rigorous IQA systems and avoidance of an expansion of bureaucracy in terms of having to collect/produce and systematise more information, install more functions related to QA (e.g. QA officers at the faculty and department level), and constantly revise and follow-up QA activities and the entire system. This is by no means a new concern and has been observed in several public sectors in terms of an audit explosion (Power 1996), audit society (Power 1999), or evaluation society (Dahler-Larsen 2012; see Ek 2012; Lindgren 2014 for Swedish examples). This conflict, and in our cases, a readily acknowledged concern, relates to our final observation. It has also been corroborated in our interviews: There is a general expansion of evaluative activities in what is developed and planned in the four HEIs. Thus, adding to the observations in the chapter "National Evaluation Systems" on the expansion of and evaluation in higher education in Sweden, this chapter has shown that the interval has not stalled the continuation of this overall growth process.

\section{Finally}

The issue of expansion is interesting from several perspectives. Even though increasing audit often includes control of control in terms of modes of selfevaluation, it is traditionally imposed on organisations from above or by external powers. This Swedish case illustrates a somewhat different development, where the policy interval has fuelled an uncompelled evaluation expansion within a "willing" higher education sector (c.f. Jacobsson and Nordström 2010). In other words, HEIs are not necessary victims of "evaluation rage"; rather, they seem to indulge in a kind of "evaluation gluttony" where enactments of EQA systems risk becoming too costly, too excessive in quality and quantity, too hasty, and too greedy. ${ }^{3}$ Apparently, HEIs - to a larger or lesser extent - see augmenting IQA systems as an important means of solving quality-based problems. They thus dedicate more time and energy, professional knowledge, and work to increasingly specialised roles and organisations of IQA. In the following chapters, we will continue to explore these issues as the reform interval comes to an end, and the 2016 national EQA system is developed (the chapter "Re-launching National Evaluation and Quality Assurance: Expectations and Preparations") and implemented (the chapter "Re-launching National Evaluation and Quality Assurance: Governing by Piloting").

${ }^{3}$ This type of gluttony is discussed among others by Aquinas (1265-1274). 


\section{References}

Aquinas, S. T. (1265-1274). Summa Theologica. Part 2-2, Question 148, Article 4.

Ball, S. J., Maguire, M., \& Braun, A. (2012). How schools do policy. Policy enactments in secondary schools. London: Routledge.

Clarke, J. (2015). Inspections: Governing at a distance. In S. Grek \& J. Lindgren (Eds.), Governing by inspection (pp. 11-26). London: Routledge.

Dahler-Larsen, P. (2012). The evaluation society. London: Routledge.

DiMaggio, P. J., \& Powell, W. W. (1983). The iron cage revisited: Institutional isomorphism and collective rationality in organizational fields. American Sociological Review, 48(2), 147-160.

Ek, E. (2012). De granskade. Om hur offentliga verksamheter görs granskningsbara [The auditees. On how public organisations are rendered auditable]. Göteborg: Förvaltningshögskolan.

ENQA. (2009). Standards and guidelines for quality assurance in the European Higher Education Area (3rd ed.). Helsinki: ENQA.

Ericson, M. (2014). Analys av Universitetskanslersämbetets utvärderingar av utbildningskvalitet år 2011-2014. Slutrapport del A [SHEA's evaluation of educational quality 2011-2014. Final report A]. Stockholm: KTH.

Forsell, A., \& Ivarsson Westberg, A. (2016). Granskningens (glömda) kostnader [Forgotten audit costs]. Statsvetenskaplig Tidskrift, 118(1), 19-37.

Government Petition 2015/2016:76. Regeringens skrivelse 2015/16:76. Kvalitetssäkring av högre utbildning [Quality assurance in higher education. Government petition to the Parliament]. Retrieved August 10, 2016, http://www.regeringen.se/contentassets/203a60faf0fb4b2f96e779 69572cadcd/kvalitetssakring-av-hogre-utbildning-skr.-20151676.pdf

Grifoll, J., Hopbach, A., Kekäläinen, H., Lugano, N., Rozsnyai, C., \& Shopov, T. (2012). Quality procedures in the European higher education area and beyond: Visions for the future. Brussels: ENQA.

Hall, P. (2012). Managementbyråkrati: organisationspolitisk makt $i$ svensk offentlig förvaltning [Management bureaucracy: Organizational political power in the Swedish public sector]. Stockholm: Liber.

Jacobsson, B., \& Nordström, A. (2010). Soft powers (in a community of the willing). In B. Jacobsson (Ed.), The European Union and the Baltic States. Changing forms of governance (pp. 163-173). London: Routledge.

Jacobsson, B., Pierre, J., \& Sundström, G. (2015). Governing the embedded state. In B. Jacobsson, J. Pierre, \& G. Sundström (Eds.), Governing the embedded state: The organisational dimension of governance (pp. 1-26). Oxford: Oxford University Press.

Latour, B. (2005). Reassembling the Social: An introduction to actor-network theory. Oxford: Oxford University Press.

Leeuw, F. L., \& Furubo, J.-E. (2008). Evaluation systems. What are they and why study them? Evaluation, 14(2), 157-169.

Lindgren, L. (2014). Det nya utvärderingsmonstret: om kvalitetsmätning i den offentliga sektorn [The new evaluation monster - About quality measurement within the public sector]. Lund: Studentlitteratur.

Lindgren, J., \& Rönnberg, L. (2017). Mimicry in an era of autonomy? Quality assurance policies in Swedish Universities. Paper presented at the European Conference of Educational Research, Copenhagen, Denmark, August 22-25, 2017.

Ministry of Education. (2015). Promemoria. U2015/1626/UH. Kvalitetssäkring av högre utbildning [Quality assurance of higher education]. Retrieved March 20, 2015, http://www.regeringen.se/rapporter/2015/03/u20151626uh/

Orion. (2016). Proposal for a model for evaluation of study programmes and courses at Orion University.

Parliamentary Decision. (2015/2016:155). Riksdagsskrivelse. https://www.riksdagen.se/sv/dokument-lagar/dokument/riksdagsskrivelse/riksdagsskrivelse-201516155_H30K155. Retrieved 18 April, 2018. 
Pegasus. (2015). Faculty minutes.

Power, M. (1996). The audit explosion. Retrieved from: http://www.demos.co.uk/files/theauditexplosion.pdf

Power, M. (1999). The audit society. Rituals of verification. Oxford: Oxford university press.

Sahlin, K., \& Wedlin, L. (2008). Circulating ideas: Imitation, translation and editing. In R. Greenwood, C. Oliver, T. B. Lawrence, \& R. E. Meyer (Eds.), The SAGE handbook of organizational institutionalism (pp. 218-242). London: SAGE Publications.

Saunders, M. (2014). Quality enhancement: An overview of lessons from the Scottish experience. In M. J. Rosa \& A. Amaral (Eds.), Quality assurance in higher education (pp. 117-131). London: Palgrave.

Segerholm, C., \& Hult, A. (2015). Manoeuvring the European Quality Landscape: The significance of ENQA policy in governing Swedish higher education. Paper presented at the European Conference for Educational Research, Budapest 8-11 September, 2015.

Segerholm, C., Rönnberg, L., Lindgren, J., Hult, A., \& Olofsson, A. (2014). Changing evaluation frameworks - Changing expectations? The case of Swedish higher education. Paper presented at the European Conference for Educational Research, Symposium Governing by Expectations: School Inspection and Evaluation across Europe and Beyond, Part 1, Porto, 2-5 September, 2014.

Segerholm, C., Hult, A., Lindgren, J., Olofsson, A., \& Rönnberg, L. (2016). Enacting a National Reform Interval: Policies and practices at universities for a new quality assurance system in Swedish higher education. Paper presented at the European Conference of Educational Research, Dublin, Ireland, August 23-26, 2016.

SNAHE. (2012). Swedish National Agency for Higher Education: Review of ENQA membership. April 2012. Retrieved March 20, 2015, http://www.csc.kth.se/ stefana/HSV_review-ENQACriteria-Report-April2012.pdf

Sørensen, M. P., Haase, S., Graversen, E. K., Kalpazidou Schmidt, E., Mejlgaard, N., Ryan, T. K., Björk, A., Møller Grønfeldt, L., Bargmann Madsen, E., \& Nyberg, M. E. (2015). Autonomi och kvalitet - ett uppföljningsprojekt om implementering och effekter av två högskolereformer $i$ Sverige [Autonomy and quality - A follow-up study on the implementation and effects of two reforms in the Swedish higher education system. Main report]. Stockholm: Riksdagen.

SOU. (2015:92). Utvecklad ledning av universitet och högskolor. [Improved Management of Higher Education Institutions] Stockholm: Wolters Kluwers.

Stake, R. E. (2006). Multiple case study analysis. New York: The Guilford Press.

Standards and Guidelines for Quality Assurance in European Higher Education Area (ESG). (2015). Brussels, Belgium.

Virgo. (2015). Internal PowerPoint presentation.

Westerheijden, D. F., Stensaker, B., \& Rosa, M. J. (Eds.). (2007). Quality assurance in higher education. Trends in regulation, translation and transformation. Dordrecht: Springer.

Open Access This chapter is licensed under the terms of the Creative Commons Attribution 4.0 International License (http://creativecommons.org/licenses/by/4.0/), which permits use, sharing, adaptation, distribution and reproduction in any medium or format, as long as you give appropriate credit to the original author(s) and the source, provide a link to the Creative Commons license and indicate if changes were made.

The images or other third party material in this chapter are included in the chapter's Creative Commons license, unless indicated otherwise in a credit line to the material. If material is not included in the chapter's Creative Commons license and your intended use is not permitted by statutory regulation or exceeds the permitted use, you will need to obtain permission directly from the copyright holder.

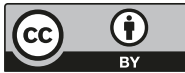




\title{
Relaunching National Evaluation and Quality Assurance: Expectations and Preparations
}

\author{
Christina Segerholm
}

\begin{abstract}
In this chapter, we describe and analyse the design of the evaluation and quality assurance system decided by the Swedish Parliament in 2016. Particular stress is put on how one part of this system - the institutional reviews of the higher education institutions' internal quality assurance processes - was set up by the Swedish Higher Education Authority (SHEA). The aim was to explore governing of higher education in the signals expressed through the design and requirements decided by the SHEA. The SHEA public reports, guidelines, criteria, and templates for the higher education institutions and evaluators, and interviews with SHEA staff were used for this purpose. The analysis shows that the Standards and Guidelines for Quality Assurance in the European Higher Education Area were important influences in the design work. It also shows that the design supports the governing by objectives and outcomes logic and a notion of "quality" in higher education as equivalent to work with internal quality assurance systems at higher education institutions. We argue that this design forms the basis for constitutive effects like an instrumental notion of higher education.
\end{abstract}

\section{Introduction}

Throughout the book, we have described and analysed the emergence of evaluation and quality assurance in the Swedish higher education system, with particular emphasis on the most recent developments. Here we will concentrate on the 2016 system, which was preceded by the highly criticised 2011-2014 system, and later by a period without national evaluation and quality assurance (EQA) characterised by a multitude of activities and discussions throughout higher education. Commissioned to develop a new national system, the Swedish Higher Education Authority (SHEA) worked intensely to create a design for a new EQA system, first

\footnotetext{
C. Segerholm $(\bowtie)$

Department of Education, Umeå University, Umeå, Sweden

e-mail: christina.segerholm@umu.se
} 
from autumn 2013 to spring 2014, at which time the government decided to appoint a special investigator. Later, when the parliament decided on the new system from spring 2016, the SHEA intensified its design work. During this period of reform interval, higher education institutions were occupied with creating and improving internal quality assurance systems that should match requirements not yet decided, as described in the chapter "Enacting a National Reform Interval in Times of Uncertainty: Evaluation Gluttony Among the Willing".

To reiterate, in March 2016, a new national EQA system for higher education was decided by the parliament. Signals to the higher education institutions (HEI) of what parliamentary decision to expect had been disseminated by a government memorandum outlining the planned system. The SHEA had also worked to spread information and collect comments about what was thought would be decided by the parliament, particularly during autumn 2015, as the chapters "Hayek and the Red Tape: The Politics of Evaluation and Quality Assurance Reform - From Shortcut Governing to Policy Rerouting" and "Enacting a National Reform Interval in Times of Uncertainty: Evaluation Gluttony Among the Willing" show. The ramifications of the new system were finally decided in March 2016. The government then commissioned the SHEA to work out the design and details and how to best implement the system. What then, did this system, look like?

In this chapter, we describe this 2016 national EQA system and pay particular attention to one component, institutional reviews of higher education institutions' internal quality assurance (IQA) systems. Our aim is to analyse this national system as a matter of what it is meant to achieve (not what it actually achieves or how and what it influences), the motives, and the direction of the governing process (what is evaluated and how) as it appears in SHEA documentary materials and staffs' experiences. We argue that the designs of national EQA systems direct attention to different parts of the HEIs' activities and organisations, and as such, designs are also part of governing higher education.

We used the following questions to organise our work with the chapter:

- What is evaluated in the 2016 national evaluation and quality assurance system? Why? By whom? How? With what consequences in terms of expectations?

- How is the work of designing the 2016 national evaluation and quality assurance system described by the SHEA actors?

- What knowledge and ideas are valued and promoted within the 2016 system in general and in the institutional reviews in particular?

- What are the implications for higher education governing?

In the chapter "Governing by Evaluation: Setting the Scene", we underscored an understanding of governing as a variety of deliberate processes and work performed by different actors, in different places through policies and various means and activities (Clarke 2015). Apart from describing the actual design of the 2016 national EQA system, this understanding also directs us to pay attention to the actors at the SHEA and their experiences in the design work. As this chapter in a way is a continuation of the retrospect in the chapter "National Evaluation Systems", we once again make use of a view of higher education based on Hopman's (2003, 2008) 
idea of a move in management, from being an internally "ill-defined problem" controlled and evaluated by professionals (colleagues/peers) called "management by placement" to a "well-defined problem" managed, controlled, and evaluated by external "expertise" using indicators and standards, called "management by expectations". Following Hopman's argument, this move is connected to issues of accountability in institutionalised practices like education, where the boundaries are weak and changing over time, rendering them "ill-defined". As education expands and its problems become even more "ill-defined", accountability demands may be harnessed by a transfer to a more "well-defined" enterprise through the use of indicators, standards, and EQA systems, since "accountability needs something that can be counted, or where it is at least possible to measure the distance between expectations and results" (Hopman 2008, p. 425). Consequently, expectations in our text denote what is at the fore of the design of the national EQA system, in the expectations, ideas, and values it promotes.

This understanding can be combined with what Dahler-Larsen $(2012,2014)$ analyses as "constitutive effects". Constitutive effects are constitutive in the sense that evaluative activities like EQAs - including indicators, criteria, and guidelines affect the phenomena, enterprises, or practises that are assured, assessed, or evaluated. Or, as Dahler-Larsen phrases it in relation to performance indicators: "The indicator helps define the concept it claims to measure" (Dahler-Larsen 2014, p. 975). This means that the designs of the national EQAs are in part defining what quality is in higher education, as well as signalling ideas of what higher education and HEIs are all about.

The chapter rests on documentary materials like public reports from the SHEA, guidelines and templates for the institutional reviews as they were tested in a pilot and quite extensive interviews with nine SHEA staff in different positions during 2015 and 2016 when the new national system was developed and implemented.

\section{The 2016 EQA System: Suspenders and Belt}

The government's arguments for the new national evaluation and quality assurance system stressed the importance of high quality in higher education in order for Sweden to be competitive and secure future work opportunities (Ministry of Education 2015, p. 3). Large investments in higher education that have proven profitable are to be followed by continued expansion of the higher education system. This calls for persistent efforts to increase quality, it was said (ibid.) One objective was that: "(a)ll female and male students should know that they receive education of high quality" (ibid.). National quality assurance was put forward as the means to achieve this. These hopes were later formulated into objectives by the SHEA, stating that the planned system was both to control the performance of study programmes and to work for quality improvements (SHEA 2016a, p. 6, b, p. 6). This balance between a system that both controls and develops is hard to strike, as was testified by staff at the SHEA: 
This is a role that we have, that these evaluations shall lead to development and the system shall be supportive, and at the same time we shall control because it is after all public funds that are used, and this ought to be controlled so they are used in the right way. It is a challenge. (SHEA staff 4, September 2016)

One prominent idea with this EQA system is that the HEIs should take on a more active role in quality assurance through internal quality assurance systems (IQA), while the SHEA should be responsible for evaluating these internal systems. "They [the HEIs, our clarification] have the major responsibility for, or they have the responsibility for quality in higher education..." (SHEA staff PB6, November 2015). Another idea of note is that the national system is to be cohesive so that it "is useful for all four components" (SHEA 2016b, p. 7; see below about components) of the system and also supports the HEIs' internal quality assurance systems. An additional pronounced idea, and also an aim, is that the system should "not only have international legitimacy, but also ultimately contribute to a greater internationalisation of Swedish higher education" (SHEA 2016b, p. 5). This is done by adhering to the Standards and Guidelines for Quality Assurance in the European Higher Education Area (2015) or the ESG. When the entire system is in place and running, the SHEA once again plans to apply for membership in the European Association for Quality Assurance in Higher Education (ENQA) (SHEA 2016a, p. 12; SHEA 2016b, p. 12). ${ }^{1}$ This is thought to enhance legitimacy for Swedish higher education abroad and facilitate student and faculty mobility. Throughout the SHEA's development work with the national system, the ESG and ENQA membership was at the fore:

...in order for us to live up to our ENQA membership, we have to do reviews of the HEIs' internal quality assurance systems, and this is something that the sector itself and the politicians stress. (SHEA staff 1, September 2016)

In the chapter "Europe in Sweden", we concluded that the SHEA has been, and still is, a central brokering/dissemination organisation for European policy on higher education and quality assurance. This is even more evident in their development work and design of the latest EQA system. The importance of the European perspective and ENQA membership is present in the SHEA report to the government, where there are constant referrals to the ESG.

Looking at other national EQA systems (the Nordic countries, England, Scotland, and the Netherlands) and relying on the internal knowledge and experience in the SHEA were important in developing of the system:

And it is a strength that we have so much experience to get both from other countries, but also from our own experience. We, in fact, have now very much experience in the organisation of evaluations, at different levels. We have the old ones, we looked at previous systems, and we have looked at processes before. We have looked at outcomes before. Now we pick the best parts of our history. (SHEA staff 4, September 2016)

\footnotetext{
${ }^{1}$ In February 2019, the SHEA announced that the process of applying for ENQA membership had begun (SHEA 2019).
} 
Compared to the preceding national EQA system, the increase of what the HEIs must pay attention to is striking. As we presented in the chapter "Enacting a National Reform Interval in Times of Uncertainty: Evaluation Gluttony Among the Willing", the EQA system is comprised of four components or types of evaluations:

- Appraisal of applications for degree-awarding powers

- Institutional reviews of the higher education institutions' quality assurance processes

- Programme evaluations

- Thematic evaluations. (SHEA 2016b, p. 16)

The first component assesses whether or not sufficient conditions exist in order for a HEI to award degrees and licenses. The second directs attention to how the HEIs' internal quality assurance activities and organisation manage to "ensure" that all courses and programmes are good enough. The third type is the evaluation of quality in study programmes and focuses on outcomes and student attainment as they are laid down in the Higher Education Act, the Higher Education Ordinance, and System of Qualifications - that is - the expected learning outcomes for different degrees and licenses (SFS 1993:100, appendix 2). The fourth component, thematic evaluations, may include such areas as sustainable development and the HEIs' work therein.

The four SHEA evaluation types also entail reviewing and assessing four so called aspect areas. They are (a) "governance and organisation"; (b) "environment, resources, and area"; (c) "design, teaching/learning, and outcomes"; and (d) "follow-up, actions, and feedback" (SHEA 2016b, p. 17). The last aspect area is integrated into the other three aspect areas, and so its assessment criteria for that aspect area are included in those of the aspects. On top of that, the evaluations include three perspectives: student and doctoral student, working life, and gender equality (see Fig. 1). The SHEA claims that all these components, aspect areas, and perspectives are based on Swedish law and ordinances and the ESG (SHEA 2016b, pp. 17-19). The gender equality perspective is a special assignment from the government and is something that "is close to their heart" (SHEA staff 3, September 2016).

All evaluations in the national EQA system are carried out through the HEIs' so called self-evaluations, external assessment panels with on-site visits and public reports with decisions and follow-ups. Different aspect areas are emphasised for each component evaluated (see Fig. 2). For example, all aspect areas are included in institutional reviews while in programme evaluations focus on aspect areas, "environment and resources" and "design, teaching/learning, and outcomes" (SHEA 2016a, p. 21). Also included in the programme evaluations - and part of the basis for judgements - are students' pre-graded degree projects (independent work papers). These are to be assessed by the external panels in order to judge whether or not the expected learning outcomes have been attained for different licenses and degrees (SHEA 2018a, p. 15).

As can be seen, the EQA system encompasses several different types of evaluations that target different parts of the HEIs. This comprehensiveness of the system is something the informants at the SHEA also brought up as a possible problem: 


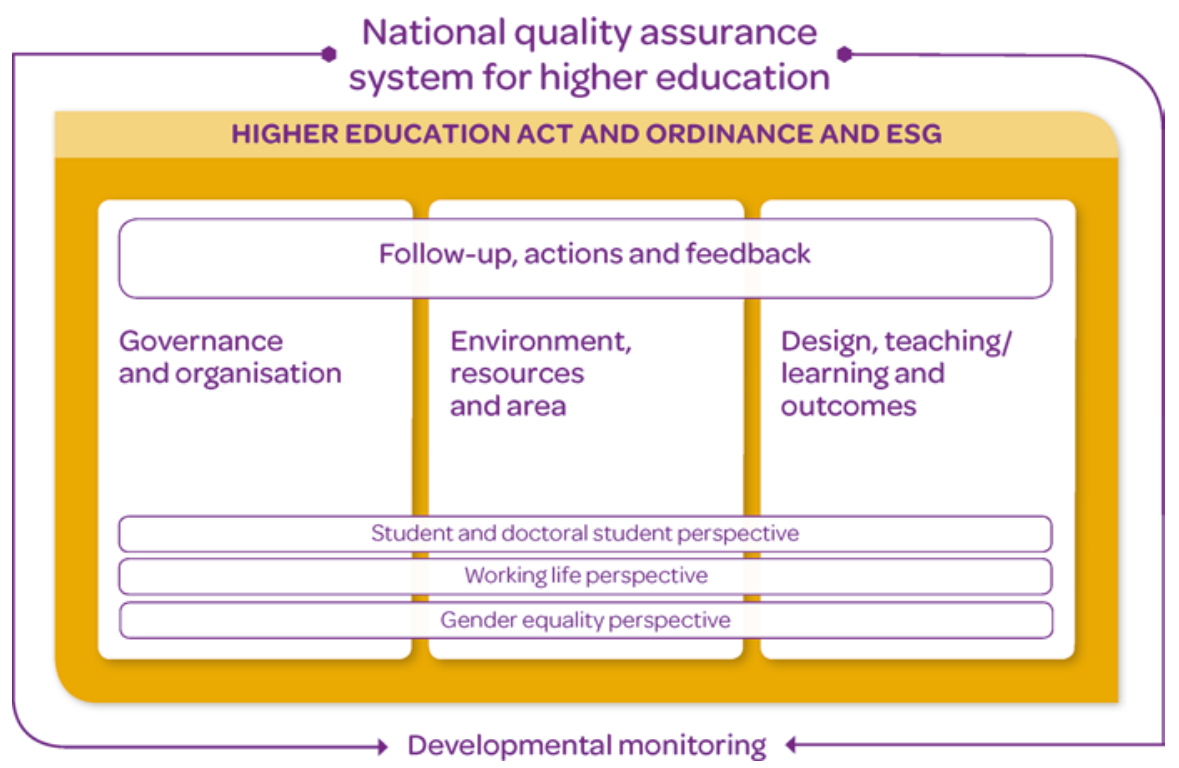

Fig. 1 Overview of components, aspect areas, and perspectives in the 2016 EQA system. (SHEA 2016b, p. 18)

National quality assurance system for higher education

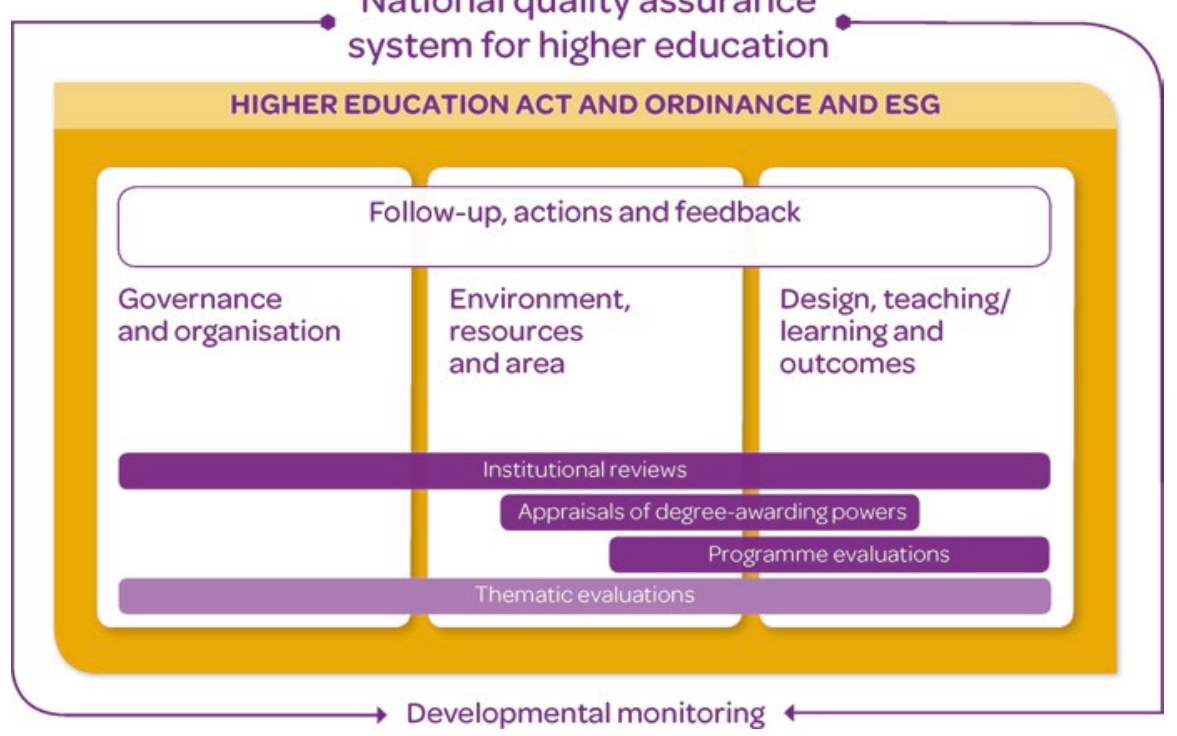

Fig. 2 Overview of what aspect areas and perspectives that are emphasised in the different evaluation types (components). (SHEA 2016b, p. 21) 
... I have said several times that I think this [the national system, our clarification] maybe will be too resource demanding. We get a bit too little out of it in relation to all the resources we put into it. Perhaps we should have skipped some of these parts. (SHEA staff 2, September 2016)

A general weakness in the whole system might be that we are now starting a giant system that includes, that is, I don't think we've had this comprehensiveness in any other national system. (--) Can we and the higher education institutions cope with this? (SHEA staff 3, September 2016)

As part of the design work and implementation process, several activities were carried out in which the evolving design was presented and feedback was collected in meetings with five reference groups that commented on the system as a whole and on the specific types of evaluations, i.e. the different perspectives, or evaluations directed at specific levels or education programmes, like teacher education (SHEA 2016 b, p. 49). More active work was also asked from the advisory group concerning the whole system and meetings with three advisory groups for specific levels or education programmes (ibid.). Furthermore, SHEA staff travelled around the country and arranged several meetings at different HEIs, in which the national system was presented and discussions were held with representatives from the HEIs. This also gave the HEIs opportunities to compare their work with the development of their internal quality assurance systems (Observation notes 12 May 2016, SHEA presentation at Faculty of Social Sciences, Umeå University). Information about the design process, information meetings, etc. was continuously displayed at the SHEA website and in their monthly newsletters.

All four types of evaluations (components) were tested in small-scale pilots during 2016-2017. These pilots were also a planned effort to implement the 2016 EQA system; we portray the pilot of institutional reviews in the next chapter. Several meetings with HEIs and external assessment panels involved in this particular pilot were carried out, and in all these evaluation processes, SHEA staff had an important role: they acted as project and process leaders, steering the evaluation processes forward and arranging all kinds of practicalities, like schedules for interviews, site visits with HEIs, and meetings and coordination of different assessors' written statements. According to the SHEA staff, it was crucial in their work to know about the Swedish higher education system, to have an academic degree in any subject, and to be socially competent and able to lead an external panel in their assessment work. They have opportunities to continuously develop their knowledge in evaluation - particularly about quality assurance - by attending international conferences, most often in the Nordic and European countries.

In October 2016, the SHEA estimated the following numbers of the different types of evaluations during 2016-2022: approximately 20 appraisals of applications for degree-awarding powers, 46 institutional reviews, 650 programme evaluations, and 2-3 thematic evaluations (SHEA n.d.). 


\section{Comments on the Design Work of the EQA System}

Designing evaluations for different purposes like control/accountability or development and capacity building is not easily done, since different purposes direct attention to different parts of what is evaluated. The Swedish EQA system is meant to entail both control/accountability/compliance and support/development/improvement of quality, meaning it has to collect information of all sorts of preconditions, processes, and outcomes at several levels in the HEIs (see, e.g. Owen 2006 for different types of evaluations for different purposes). Assessment criteria also have to be developed for each of these parts. The SHEA staff expressed some critical insights about the system's comprehensiveness, both concerning their own work and on behalf of the HEIs. It is rather easy to imagine the enormous amount of time that has to be spent on collecting information, making sense of it in self-evaluations, assessment processes, writing reports, etc. Any given HEI is probably going to be involved in and have to respond to a number of these nationally required EQA processes, as well as carry out their internal system processes. Over the years, and through working with the requirements of different national EQA systems, the staff are likely to accumulate knowledge on EQA and the different meanings of quality in higher education.

Designing the 2016 national EQA system, implementing it, and thus making it the national policy entail a lot of work: internal activities at the SHEA discussing different approaches and directions of the system, arranging meetings with reference and advisory groups and HEIs, visiting and learning about other countries' national systems, continually up-dating and disseminating information, etc.

What we now see is a national system that has parts of all the previous systems that were described in the chapter "National Evaluation Systems" or covers most ingredients of evaluations in higher education (Harvey 2010). It may be conceived as a sort of sedimentation/layering (Bleiklie and Kogan 2007, p. 482) of former ideas, expectations, experiences, activities, and knowledge. However, as Harvey and Newton point out, it is not easy to know exactly what the purpose(s) of the national system is, whether it is "the educational provider, or the specific programme, or the learner, or the output of the programme or the institution" that are the ultimate aim (Harvey and Newton 2004, p. 150); rather, it is all the evaluation objects that are targeted by the four components. Following Harvey and Newton (2004) and their analysis of external quality evaluations in higher education, it can be argued that the model of self-evaluation, external review, public report, and follow-up may not be the most appropriate for all these different purposes, intentions, directions, aspect areas, and perspectives. When the SHEA fully and energetically emphasises and incorporates the ESG, this also means that the EQA system indirectly promotes a behaviouristic view of learning, as the ESG concerned with learning, teaching, and assessment (Standards and Guidelines for Quality Assurance in the European Higher Education Area 2015, p. 12) is based on and sustains a behaviourist epistemology with predefined end behaviour and outcomes, as shown by Murtonen et al. (2017). Apparently, this is also something that goes hand-in-hand with the 
implementation of the Bologna Process (Murtonen et al. 2017, pp. 114-117). Several research studies have shown that such an epistemology is a restricted theoretical basis for education, teaching, and learning because these processes also include cognitive and social processes that are more open-ended as to what the knowledge outcomes may be (Murtonen et al. 2017). As a complimentary understanding of learning, Marton et al. (2008) offer a viewpoint based on phenomenography in order to achieve higher order learning, holistic understanding, and deep learning in higher education.

With these remarks about the overall 2016 EQA system, we move to the component institutional reviews of the HEIs' internal quality assurance systems. The reason we concentrate on this evaluation type is that it is the most comprehensive one; this type was also underscored in policy texts, arguing that more responsibility for quality in higher education should rest on the higher education institutions themselves.

\section{The Institutional Reviews: Quality as Assuring Quality Assurance}

In this section, we describe the design of the institutional reviews of HEIs' internal quality assurance systems as it was set up for the pilot of this type of evaluations. Pilots were performed as part of the implementation process of the new national system.

In the Swedish language guidelines, the purpose of the institutional reviews is stated as:

to control that the HEIs' internal quality assurance work ensures high quality in courses and programmes, and to contribute to the HEIs' quality development. (SHEA 2016c, p. 8, our italics)

Time and resources were also spent on translating these guidelines into English in order to facilitate international understanding or make recruitment of foreign assessors easier, as we understand it. The meaning is slightly different in the English translation and is an example of how the meaning is somewhat changed in the processes of translation. In our view, the Swedish version expresses a harsher tone, compared to the English version, reading as follows:

to examine whether these processes ensure high quality courses and programmes and to support the HEI's quality improvement efforts. (SHEA 2016d, p. 8, our italics)

There is also another purpose, linked to European policy. Again, it has to do with Sweden's - or to be more precise, the SHEA's - membership status in the ENQA. In order to be eligible according to ENQA requirements, the applicant has to live up to all ESG. The HEIs' internal quality systems are a cornerstone of these requirements that must be reviewed by an external evaluation agency, as described in the chapter "Europe in Sweden". With reference to these ENQA requirements, one SHEA staff said: "We can't say that Sweden should have its own sort, (---) So therefore, the new 
ESG have been very central. We have worked a lot with them when it comes to this component, the institutional reviews" (SHEA staff 2, September 2016).

Other ambitions with the institutional reviews are to push the HEIs "a step further" and to have them ask questions like:

...but how do you know that you have control? What do you have, how can you verify it and how do you use the information you get? What measures do you take if you find things that work a bit poor, and at the same time how can you spread good examples? (SHEA staff 1 , September 2016)

The institutional reviews are said to be based on the Higher Education Act, the Higher Education Ordinance, the System for Qualifications, and the ESG. The importance of the ESG was repeatedly stressed by the SHEA staff:

We worked a lot in relation to the ESG when it comes to the institutional reviews. So, the ESG have become a very, (---) that is, the ESG have been revised during this period, so there were new ESG. [We] translated them into Swedish. It is the ESG in English that are valid, but we did a Swedish translation and put down quite a lot of resources into it. (SHEA staff 2, September 2016)

These institutional reviews are aimed at assessing how well the HEIs' internal quality systems contribute to "ensure and improve the quality of courses and programmes at all education cycles, and covers all aspect areas and perspectives" (SHEA 2016d, p. 9). Furthermore, the reviewers assess how systematic, effective, and proactive the HEIs' internal quality systems are, as well as their integration in the HEIs' organisation and the activities they have. It is clear from the guidelines for the institutional reviews that such characteristics are necessary in order to be judged adequate.

The aspect areas and perspectives in the institutional reviews are the same as the ones listed above, and every aspect area is in turn divided into a number of narrower aspects. These different aspects and the three perspectives are each assessed based on criteria developed for that particular aspect or perspective (SHEA 2016c, p. 9). Criteria for the different aspects closely follow the ESG; even so, some modifications are visible due to the national context and how to translate and interpret the ESG so as to fit Swedish legislation and academic tradition.

There are different types of materials that are part of the reviews and on which the judgements are made, including descriptive statistics from the SHEA, a so-called self-evaluation report by the HEIs, a student report, web interviews, site visits, and areas of focus (SHEA 2016d, pp. 9-12). The self-evaluation report should be no longer than 50 pages, written in a set template developed by the SHEA and organised around the main ESG (Part 1) within each aspect area (see Fig. 3).

As an example, Part 1 of the ESG is directed at "Student-centred learning, teaching and assessment" (Standards and Guidelines for Quality Assurance in the European Higher Education Area (ESG) 2015, p. 12). One of the guidelines for that standard reads: "The assessment allows students to demonstrate the extent to which the intended learning outcomes have been achieved" (ibid.). In the guidelines for the pilot of the institutional reviews, this is operationalised into the assessment criteria: 
cont. Aspect area: Design, teaching/learning and outcomes

\subsection{Aspect: Goal attainment}

\begin{tabular}{ll}
$\begin{array}{l}\text { Assessment } \\
\text { criteria }\end{array}$ & $\begin{array}{l}\text { A. The HEl ensures that its courses and programmes are } \\
\text { designed, developed and implemented with a clear connection } \\
\text { between national and local goals, teaching activities and } \\
\text { examinations. The HEl ensures that all students have good } \\
\text { potential for achieving their established goals within the planned } \\
\text { time. }\end{array}$ \\
& $\begin{array}{l}\text { B. The HEI works systematically to follow up and evaluate whether } \\
\text { students' actual learning outcomes correspond with the expected } \\
\text { learning outcomes. Planned or implemented measures following } \\
\text { such a review are communicated to the relevant stakeholders. }\end{array}$ \\
\hline $\begin{array}{l}\text { Guidelines for } \\
\text { HEls }\end{array}$ & $\begin{array}{l}\text { for meeting the assessment criteria and analyse the strengths } \\
\text { and areas for improvement. It is good to illustrate the report } \\
\text { with specific examples of how the systematic quality assurance } \\
\text { procedures are evident in and contribute to improving the } \\
\text { operation. In addition, include the student and doctoral student } \\
\text { perspective, employer and labour market perspective and gender } \\
\text { equality perspective when relevant. }\end{array}$
\end{tabular}

Fig. 3 Illustration of try-out guidelines translated into English by the SHEA. (SHEA 2016d, p. 25)

The HEI works systematically to follow up and evaluate whether students' actual learning outcomes correspond with the expected learning outcomes. Planned or implemented measures following such a review are communicated to the relevant stakeholders. (SHEA 2016d, p. 25) ${ }^{2}$

The HEIs should assess how well their internal quality assurance system fulfils the requirements set in the guidelines for all aspects and perspectives (SHEA 2016d, p. 25). The student report is meant to give students a chance to express their views on five pages at a maximum. The SHEA materials, the self-evaluations, and the student reports should be uploaded to a particular electronic system that the SHEA has developed for this purpose, called UKÄ Direkt (ibid.).

In the description of the pilot of institutional reviews, web-based interviews are to be conducted approximately 5 weeks after the self-evaluations have been uploaded in UKÄ Direkt. One purpose of these web interviews is to clarify issues raised from the self-evaluations and to prepare areas of focus (SHEA 2016d, pp. 11-12) chosen by the external panel in order to check whether or not claims in the self-evaluation reports are really practised. For example, the panel could check if course evaluations are systematically performed and their results communicated to relevant stakeholders. Areas of focus are checked in the site visit, mainly by

\footnotetext{
${ }^{2}$ This wording is not dramatically changed in the revised guidelines from 2018 (SHEA 2018b, p. 14).
} 
interviews with head management, academic leaders, faculty, and students and/or doctoral students (ibid.).

The number of assessors in the external assessment panel for the institutional reviews is not specified, in the pilot guidelines (SHEA 2016d, pp. 12-13). However, other requirements on the external panel include at least one assessor with international experience and one assessor with expertise in the Swedish higher education system. One assessor should be a student representative, and another must be an employer and labour market representative (ibid.). Furthermore, the instructions in the guidelines list what the assessors' assignments as:

- Discussing the assessment of aspect areas, aspects, perspectives, and assessment criteria

- Participating in meetings during the entire evaluation process

- Representation at the initial meeting with the HEIs to be included in the evaluation

- Reviewing the various assessment criteria, justifying the reviews in writing, and specifying what data the reviews are based on

- Jointly preparing questions for interviews with HEI, student, and any employer and labour market representatives that the HEI cooperates with

- Summarising the assessments in a joint statement including the assessment panel's joint judgement and proposed decision (SHEA 2016d, p. 13)

The HEIs are asked to nominate assessors to the external assessment panels, but the SHEA has the final say. It is sometimes hard to compose a panel from the nominations, meaning that the SHEA staff have to recruit assessors:

but it was, it was just two out of four who I picked from the nomination list (---) one assessor who was in the old, that is, when we reviewed the HEIs' internal quality systems in an earlier cycle 2008 or 2009. (Hawke project leader SHEA, ${ }^{3}$ March 2017)

Once recruited, the assessors should partake in a short training session (1-2 days in the pilot) to inform them of this particular type of evaluation, the ESG, and, most importantly, to ensure they have a common understanding of the criteria and that the review is carried out as it is supposed to be carried out: "( $\mathrm{t}$ )heir assignment and role should be clear, and they should understand, have a common picture of the whole" (SHEA staff Utb, March 2017). They are also informed about the electronic device on which they communicate within the panel, the UKÄ Bedömarvy. According to the SHEA staff, useful knowledge, competences, and/or experiences for the external assessors are that they "have worked at a more central level at their higher education institutions" (SHEA staff 1, September 2016), such as vice chancellors or deans; some international experience and experience in evaluations and working in groups are valuable. The guidelines urge thorough knowledge on the Swedish higher education system and quality assurance (SHEA 2016d, p. 13).

All aspects and perspectives should be assessed in relation to their specific criteria, and the instructions to the external panels specify that these "must be judged as satisfactory for the overall assessment to be positive" (SHEA 2016d, p. 13). Furthermore, the external panel should:

\footnotetext{
3 "Hawke" refers to the HEI that was under review. Other HEIs in our materials on institutional reviews were Eagle and Falcon.
} 
...focus on the results of the quality assurance procedure - that is - that it systematically and effectively ensures and improves the courses and programmes. In addition, an assessment will be conducted of how well the HEI's quality assurance procedure systematically identifies strengths and ensures they are maintained and developed, as well as how the areas for improvement are identified, followed up and addressed. In this context, the SHEA would like to emphasise that it is considered positive for the quality assurance procedure to be able to identify and manage deviations and areas for improvement. How relevant stakeholders are given the results of the quality assurance procedure is also to be assessed. (SHEA 2016d, p. 13)

A preliminary report from the external assessment panel should be sent to the HEIs under review for them to correct and comment on any factual errors. A final report is the basis for the SHEA decision, with the rating in the pilot on a two-point scale: approved or not approved (SHEA 2016d, p. 14). For HEIs that are not judged as approved, there are follow-ups within a year with reviews of the improvements deemed necessary by an external panel. The HEIs should then show what measures they have taken to come to correct these weaknesses. Experiences and good examples are also to be communicated in feedback conferences and dialogue with the HEIs under review independent of the judgements (SHEA 2016d, p. 14).

The SHEA staff who worked to develop the new EQA system are strong believers in evaluation and quality assurance. They expect that the institutional reviews will lead to "...the development of faculty competences - that they learn" (Eagle project leader SHEA, March 2017), or that "on a more overarching level, they [the HEIs, our clarification] will have to shape up (---) and hopefully this seeps down to the courses and programmes so they become better" (SHEA staff 5, March 2017). Other expectations concern the possibility that the institutional reviews enhance students' perspective and make the HEIs better prepare the students for working life, so that higher education is useful and the reviews ensure students' rights to good education. There are also some more cautious thoughts about what these reviews may do to the HEIs, albeit not many:

We must not forget that the choices we make when it comes to focus and our basis, become very normative for the higher education institutions' continued quality assurance work, and this is something that has to be handled responsibly. (-------)

Now when we do the institutional reviews, and focus is on talking about the ESG, that the higher education institutions should do their own follow-ups and evaluation. Of course, it is clear, that there will be a lot of focus on that now. (SHEA staff 1, September 2016)

\section{Comments on the Design Work of the Institutional Reviews}

The institutional reviews are aimed at assessing HEIs' internal quality assurance systems, and these have to live up to the ESG as is also expressed in the overall 2016 national EQA system. We have demonstrated the ambitious work the SHEA laid down in translating the ESG into Swedish and align the institutional reviews with them. Here, the influx of European quality assurance policy becomes or is transduced 
into actual design work and work with guidelines, templates, instructions, and training.

The SHEA also translated the institutional review guidelines into English. Translations from one language to another always pose some difficulties when it comes to expressing the meaning of the words. The citations from the two guidelines show that the term "control" (kontroll in Swedish) is translated to "examine" in the English language guidelines, and "contribute" to "development" in the Swedish version (bidra till kvalitetsutveckling in Swedish) is translated to "support improvements" in the English version. Our point is that policy and governing work always include translations of different kinds; these shifts in meaning may be more in tune with the ESG, as they are expressed in the English language. However, another type of translation is also visible in the design and implementation process of the institutional reviews: translating the ESG into criteria that are meaningful in a Swedish higher education institution context.

Notable in the institutional reviews are the rather strong political ambitions to get the HEIs to work more intensely on gender equality issues. A stress on HEIs to become more market oriented is visible in the requirement of representatives from that perspective in the external assessment panels and in this particular perspective in the guidelines. Similar changes in higher education have been reported from other countries in several studies (e.g. Massen and Stensaker 2011; Schuetze et al. 2012). Student influence is also stressed and goes hand in hand with an increased ambition to pay attention to students' rights, as a matter of individualised learning.

The behaviouristic understanding of education and learning is also evident in the institutional reviews, as the ESGs are so conspicuously used as a basis for judgement. We note that judgements and the process of assessment in these reviews are based on a theory of analytic assessment where separate judgements are made on each of the pre-set criteria and then aggregated. The final judgement is "then built up from a series of small-scale decisions. When the steps are followed systematically, the grade follows as a logic outcome" (Sadler 2009, p. 161). According to Sadler (2009), such assessments may be rather inadequate for making judgements based on more open-ended and compiled materials, such as those used in the self-evaluation report and interview answers.

Central to quality assurance would be what meaning "quality" is given in the design, in the guidelines, and in the actual processes. Our interpretation of the design and the guidelines of the institutional reviews is that quality in higher education is fundamentally constructed as equivalent to the existence of internal quality assurance systems at the HEIs, which should assure high quality. Whether or not such systems actually do so is not really possible to know, since "high quality" is not defined. On the other hand, our analysis shows that the design and guidelines signal and underline the goal-/objective- and outcomes-/results-oriented rationale of governing; a gender equality perspective; a labour market perspective; and a student influence perspective. This view of quality in higher education is only slightly compatible with what the vice chancellors expressed as quality in higher education in the chapter "Navigating Higher Education Institutions in Times of Quality Assurance - The Assumptive Worlds of Vice Chancellors". It is perhaps a conscious 
decision by the SHEA to leave the main part of handling the "What is quality?" question to the HEIs. It is also in line with what is commonly referred to as "academic freedom" (Polanyi 1951, in Hartl 2012, p. 310) or faculty power over the scientific content and assessment of quality, in research and higher education. However, the design of the institutional reviews requires the HEIs to set up internal quality assurance systems that match the criteria of all aspects and perspectives, circumscribing such power and power to decide how the HEIs' internal resources are best used to achieve good education and research practice.

\section{Discussion}

The 2016 EQA system's overall design and work, as well as the institutional reviews, are based on the ESG. This means that the European higher education and quality assurance policy now is fully incorporated in the Swedish higher education policy context. It still remains to be seen whether or not this system is considered by the ENQA to be independent enough in relation to the government. Throughout the design process, the SHEA worked diligently to align the national system and institutional reviews with the ESG. This work entailed interpretations and translations of different kinds and in Freeman's words: "to translate is to represent in a new form something previously or otherwise represented differently in another language or medium" (Freeman 2006, p. 1). We have shown that shifts in meaning exist in language translations but are used in order to make the ESG acceptable in the context of Swedish higher education context. This is in part how European policy travels and is made acceptable in different nations (e.g. Grek and Lawn 2012).

We interpret the design to show some particular Swedish values, including political stress on gender equality, the labour market, and student influence. Although not absent in global or European education policy, the refinement of those perspectives is related to increased political pressure and expectations of the entire Swedish education system to work more intensely in these directions.

The SHEA staff developed aspect areas, criteria, guidelines, etc. for the 2016 system. They worked with the ESG and how to help them function in the Swedish context. They worked with the incorporation of political demands on higher education (like gender equality and labour market perspectives) and constant dissemination of information. In this work, the SHEA also spent time and energy to consult several advisory and reference groups, as well as arranging discussions with stakeholders. These efforts lead to a comprehensive national EQA system further supported by the component institutional reviews. With the SHEA's clever requirements of the HEIs to take part in national EQA processes and to develop internal quality assurance systems, external and internal scrutiny merges and has the potential to reach far into educational practice. Hence, consequences of the institutional reviews will be that the HEIs are expected to live up to this comprehensiveness, which demands resources: not only must they develop and add to existing IQA systems; they must also organise internal work to respond to the 
requested activities of the other types of evaluations administered by the SHEA. For example, the programme evaluations judge their ability to meet national standards of goal attainment set by the external panels. Expectations of what knowledge, skills, and values to include in programmes and courses are thereby communicated to faculty and students, as well as how students' degree papers should be assessed, albeit indirectly. This is yet another signal and possible constitutive effect (Dahler Larsen 2012, 2014) that sustains the objective-/goal- and results-/outcomes-oriented rationale of governing higher education. It also represents a particular view of education, teaching, and learning that may influence teachers', students', and researchers' understanding of what it means to be a teacher or a student and the meaning of higher education and knowledge generation as processes. According to this rationale, education and research are conceived as entirely predictable, while learning and new scientific insights most often are open-ended and unpredictable. In Hopman's (2008) words, the design of the 2016 EQA system turns higher education into a "well-defined" problem, managed by external "expertise" using indicators and standards that direct what is expected from the HEIs.

In our description and analysis of the design of the 2016 EQA system, we have observed that the meaning of "quality" in higher education largely seems to rest on the existence of extensive internal quality assurance systems at the HEIs. Based on this fact, another possible constitutive effect may be that such a conception of quality becomes more widespread in the future (Dahler Larsen 2012, 2014).

\section{Finally}

The transformation of national EQA policy for higher education into a concrete design of a national system is part of the governing work at the state level, as we have shown in the description of the SHEA's work in setting up the 2016 EQA system. More everyday national EQA work also demands activities. Pilots were conducted to fine-tune the design of all four components and as an implementation strategy. What happened when the design was put into "action", so to speak? In the next chapter, we explore this by following the pilot of institutional reviews.

\section{References}

Bleiklie, I., \& Kogan, M. (2007). Organization and governance of universities. Higher Education Policy, 20, 477-493.

Clarke, J. (2015). Inspections. Governing at a distance. In S. Grek \& J. Lindgren (Eds.), Governing by inspection (pp. 11-26). London: Routledge.

Dahler-Larsen, P. (2012). Constitutive effects as a social accomplishment: A qualitative study of the political in testing. Education Inquiry, 3(2), 171-186. 
Dahler-Larsen, P. (2014). Constitutive effects of performance indicators: Getting beyond unintended consequences. Public Management Review, 16(7), 969-986.

Freeman, R. (2006) What is translation? Rethinking relationships between research, policy and practice. Unpublished paper. Edinburgh: University of Edinburgh.

Grek, S., \& Lawn, M. (2012). Europeanizing education. Governing a new policy space. Oxford: Symposium Books.

Hartl, P. (2012). Michael Polanyi on the freedom of science. Synthesis Philosophica, 54(2), 307-321.

Harvey, L. (2010). Evaluation for what? Teaching in Higher Education, 7(3), 245-263.

Harvey, L., \& Newton, J. (2004). Transforming quality evaluation. Quality in Higher Education, 10(2), 149-165.

Hopman, S. T. (2003). On the evaluation of curriculum reforms. Journal of Curriculum Studies, $35(4), 459-478$.

Hopman, S. T. (2008). No child, no school, no state left behind: Schooling in the age of accountability. Journal of Curriculum Studies, 40(4), 417-456.

Marton, F., Hounsell, D. \& Entwistle, N. (Eds.) (2008). Hur vi lär (3rd ed.) [How we learn]. Stockholm: Norstedts akademiska förlag.

Massen, P., \& Stensaker, B. (2011). The knowledge triangle: European higher education policy logics and policy implications. Higher Education, 61, 757-769.

Ministry of Education. (2015). Promemoria. U2015/1626/UH. Kvalitetssäkring av högre utbildning [Quality assurance of higher education]. Retrieved 20 March 2015, http://www.regeringen.se/rapporter/2015/03/u20151626uh/

Murtonen, M., Gruber, H., \& Lehtinen, E. (2017). The return of behaviourist epistemology: A review of learning outcomes studies. Educational Research Review, 22, 114-128.

Owen, J. M. (2006). Program evaluation. Forms and approaches (3rd ed.). New York: Guilford Press.

Polanyi, M. (1951). Foundations of academic freedom. In M. Polanyi (Ed.), The logic of liberty. London: Routledge and Kegan Paul Ltd.

Sadler, R. (2009). Indetermancy in the use of preset criteria for assessment and grading. Assessment \& Evaluation in Higher Education, 34(2), 159-179.

Schuetze, H. G., Bruneau, W., \& Grosjean, G. (Eds.). (2012). University governance and reform. Policy, fads, and experience in international perspective. New York: Palgrave Macmillian.

SFS 1993:100. Högskoleförordning [The Higher Education Ordinance].

SHEA. (2016a). Nationellt system för kvalitetssäkring av högre utbildning. Redovisning av ett regeringsuppdrag. Rapport, 2016, 15. [National system for quality assurance of higher education. Presentation of a government assignment]. Stockholm: The Swedish Higher Education Authority.

SHEA. (2016b). National system for quality assurance of higher education. Presentation of a government assignment. Report, 2016, 15. Stockholm: The Swedish Higher Education Authority.

SHEA. (2016c). Vägledning för granskning av lärosätenas kvalitetssäkringsarbete. Pilotstudie [Guidelines for reviewing quality assurance procedures of higher education institutions. Pilot study]. Stockholm: The Swedish Higher Education Authority.

SHEA. (2016d). Guidelines for reviewing quality assurance procedures of higher education institutions. Pilot study. Stockholm: The Swedish Higher Education Authority.

SHEA. (2018a). Vägledning för utbildningsutvärdering på grundnivå och avancerad nivå [Guidelines for programme evaluation]. Stockholm: The Swedish Higher Education Authority.

SHEA. (2018b). Vägledning för granskning av lärosätenas kvalitetssäkringsarbete [Guidelines for reviewing quality assurance procedures of higher education institutions. In Swedish]. Stockholm: The Swedish Higher Education Authority. 
SHEA. (2019). Nyhetsbrev 14 februari. UKÄ siktar mot ENQA [Newsletter 14 February. The SHEA aims at ENQA]. Retrieved February 14, 2019, https://www.uka.se/om-oss/aktuellt/ intervjuer/2019-02-14-uka-siktar-mot-enqa.html

SHEA. (n.d.). SHEA presentation materials, October 2016. Stockholm: The Swedish Higher Education Authority.

Standards and Guidelines for Quality Assurance in the European Higher Education Area (ESG) (2015). Belgium, Brussels.

Open Access This chapter is licensed under the terms of the Creative Commons Attribution 4.0 International License (http://creativecommons.org/licenses/by/4.0/), which permits use, sharing, adaptation, distribution and reproduction in any medium or format, as long as you give appropriate credit to the original author(s) and the source, provide a link to the Creative Commons license and indicate if changes were made.

The images or other third party material in this chapter are included in the chapter's Creative Commons license, unless indicated otherwise in a credit line to the material. If material is not included in the chapter's Creative Commons license and your intended use is not permitted by statutory regulation or exceeds the permitted use, you will need to obtain permission directly from the copyright holder.

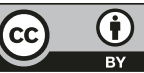




\title{
Relaunching National Evaluation and Quality Assurance: Governing by Piloting
}

\author{
Joakim Lindgren, Linda Rönnberg, Agneta Hult, and Christina Segerholm
}

\begin{abstract}
This chapter seeks to explore and discuss enactments in the process of piloting a part of the 2016 national evaluation and quality assurance system, namely, the pilot of institutional reviews in which higher education institutions' internal quality assurance systems were evaluated by the Swedish Higher Education Authority. The chapter analyses the work and experiences of the different actors that took part in these processes. It shows that the pilot includes extensive work that links people, places, policies, practices, and power in particular ways and that numerous translations are made at different stages and by different actors. The results highlight the amount and forms of work done in these processes in general and in particular by actors who we have labelled "qualocrats". Their embodied form of expertise is mobilised as they move between and across different domains to enact and promote certain knowledge in and of evaluation and quality assurance. The chapter finally suggests that the deliberate temporal design as a pilot study opened up for mutual adjustments, learning, and dialogue but also gave rise to contradictory anticipatory governing signals.
\end{abstract}

\section{Introduction}

In this chapter, we turn to the implementation of the intentions of the 2016 national evaluation and quality assurance system that was analysed in the previous chapter. More specifically, this chapter focuses on a particular part of the national evaluation and quality assurance (EQA) system, namely, the Swedish Higher Education Authority's (SHEA) institutional review of higher education institutions' (HEIs)

\footnotetext{
J. Lindgren $(\varangle) \cdot$ L. Rönnberg

Department of Applied Educational Science, Umeå University, Umeå, Sweden e-mail: joakim.lindgren@umu.se; linda.ronnberg@umu.se
}

\author{
A. Hult · C. Segerholm \\ Department of Education, Umeå University, Umeå, Sweden \\ e-mail: agneta.hult@umu.se; christina.segerholm@umu.se
}


internal quality assurance systems and processes (IQA). This form of external national evaluation was piloted on a small scale to test and develop the institutional review before its full-scale implementation, which was carried out during 2017 and included a handful of HEIs. We examined this pilot study at two of these HEIs (the Falcon and the Eagle) as the institutional review unfolded.

This chapter aims to explore and discuss enactments in the 2016 EQA pilot process of so-called institutional reviews in which HEIs' IQA systems were evaluated. We do this by analysing different actors' work and experiences. Returning to our theoretical understanding of governing as a verb, and thereby "doings", and our interest in exploring the relationships between governing, evaluation, and knowledge, these questions serve as guides:

- What enactments did the pilot entail, and what actors were involved?

- What kind of knowledge was mobilised and used in these enactments?

- How can we understand the pilot as governing in relation to the higher education institutions taking part in the pilot and in relation to the higher education sector as a whole?

We did about 30 interviews with actors working at the SHEA in external assessor panels and at different levels at the assessed HEIs. We did initial and follow-up interviews with these actors to capture experiences and opinions as close to the unfolding of events in the pilot as possible. We asked questions about thoughts and experiences from the different stages in these processes, as well as more general questions about perceptions of quality and EQA, to contextualise and situate the responses. We also collected and analysed a range of documentary materials, such as schedules and plans for the pilot study, assessment panels' reports, and the pilot decisions by the SHEA. Another crucial artefact in the pilot was the self-evaluations from the HEIs. A self-evaluation is an instrument that literally materialises core aspects of governing through knowledge. The act of writing involves a transformation of knowledge from the diffused and abstract forms that it may take in actions, practices, and peoples' minds into (supposedly) more concrete textual forms. Like all the other methods in the pilot portfolio, self-evaluation is not a direct evaluation of first-order activities; it is a mode of "control of control" (Power 1994, p. 15) that renders quality visible to external observers through inscription. However, the production of self-evaluations does not only make quality observable, it may also consolidate processes of meaning making; self-evaluations may "construct and define quality itself" (Power 1994, p. 293).

In particular, we studied the review of two HEIs: the Falcon and the Eagle. These HEIs are neither full universities nor extremely small and/or specialised, and this was our main reason for focusing on these HEIs for a more in-depth study of the work, experiences, and governing in the SHEA pilot.

The rest of the chapter has the following structure: next, a description of the institutional review process offers a brief chronological overview of the process in the pilot. These stages, starting with preparatory work and ending in post-decision actions and reactions, are dealt with in more detail and with a particular focus on "governing work" (cf. Clarke 2015). We do this by analysing different actors' 
activities, including what they were doing and what they experienced, throughout the different stages. After this, the chapter situates the pilot in relation to our analytical frame by revisiting the initial three guiding questions.

\section{The Sequencing of the Review}

Looking at the SHEA's work, extensive preparation work for the pilot was carried out by the agency - not in the least by designing the process for the pilot (see the chapter "Relaunching National Evaluation and Quality Assurance: Expectations and Preparations") or by developing guidelines, templates, and materials for external assessor panels' training, as well as by developing electronic software for sharing and storing information. Meetings with HEIs and others to disseminate information about the new EQA system and the design of the activity studied here that is, the institutional reviews of HEIs' IQA system - were also carried out. The HEIs that took part in the pilot volunteered to do so, which is important to recognise as one premise for the entire process. Another premise for the participating HEIs was set by the SHEA; this premise stated that any HEIs that would pass the pilot review and that were approved did not need to be reassessed in the full scale and mandatory cycle, while those that were not approved had to be reviewed again at a later date as a part of the mandatory cycle.

\section{The Sequencing of the Pilot}

The pilot started with an initial information meeting organised by the SHEA that targeted representatives from the handful of HEIs included in the pilot and the chairmen of the external assessor panels (one panel for each HEI). The SHEA staff - that is, the project leaders for the individual HEIs taking part in the pilot were also at this meeting. The next step in the review process was the production of the HEIs' self-evaluation reports to be submitted to the SHEA approximately 2.5 months after the initial start-up meeting. About a month after receiving the selfevaluation reports, the external assessment panels, assisted by the SHEA project leaders, conducted web-based interviews with the HEIs. About 1.5 months after the web-based interviews, site visits took place at the HEIs. Members of the external assessment panels were accompanied and assisted by the SHEA project leaders during this process. Over a period of 2 months, the panels worked on finalising their reports. The finalisation of the report also included a meeting, during which all assessors met with the SHEA project leaders to discuss the different assessments with an aim of comparability between the panels in the review. Ten months after the initial information meeting, preliminary reports from the external assessor panels were sent to the HEIs for comments (called "sharing"), meaning that the HEIs were provided an opportunity to correct factual errors and comment on the reports. The 
reports were then finalised, and the SHEA published their decisions, which included the final report by the external assessment panels.

\section{Preparing to Assess and Preparing to Be Assessed}

In the following section, we examine different stages in the process outlined above more closely by highlighting how central groups of actors in this pilot study (HEI staff, assessors, and SHEA staff) initially enacted the different stages of the institutional review by turning to their preparatory work.

\section{HEIs}

As noted above, participation in the pilot was voluntary. The decision to take part, however, was based on different justifications in the two HEIs. Falcon management, who had an IQA system in operation, said that "we were ready [mature] for audit" (Falcon Vice Chancellor). Key actors within the management had been involved in national policy discussions, knowledge exchanges, and preparations of the new national system, such as in a referential group within the SHEA and the quality group of the Association of Swedish Higher Education Institutions (ASHEI, in Swedish $S U H F$ ), which organises vice chancellors and top-level HEI management. ${ }^{1}$ The experiences managers at the Falcon had participating in such higher education networks provided insights into the new national system in general and into the institutional pilot review in particular. As a result, the invitation to take part in the pilot was enthusiastically accepted at the Falcon based on the conviction that this pilot could stimulate the improvement of an already existing IQA.

The Eagle joined the pilot on rather different grounds. Participation was justified on the basis that it could offer external help in setting up and developing their IQA: "we may not be ready, but we will learn a lot on the way" (Eagle Vice Chancellor). Efforts at the Eagle to set up the new IQA were paralleled with no less than three other external evaluations in 2017. This engagement in evaluative practices is emblamatic for the zeitgeist and something that the forthcoming account of the pilot will provide many examples of.

After being accepted for inclusion, the two HEIs immediately initiated extensive efforts to organise the internal work in terms of roles and tasks. First, the review process had to be thoroughly scheduled and coordinated in alignment with the overall SHEA schedule. Each HEI carried out inventories to find out what the organisation knew about itself. For example, they had to identify who in the

\footnotetext{
${ }^{1}$ Among other things, ASHEI works to disseminate knowledge of and in the HEI sector, for instance, to develop common policy directions for HEIs and by policy advocacy aimed at the Ministry of Education and other policymaking bodies.
} 
organisation carried specific knowledge about particular organisational areas and processes and what internal documents could make that knowledge visible. They had to identify key actors within the organisation who could provide such knowledge as a part of the self-evaluations and/or answer questions about the IQA in the upcoming interviews. Soon after, the HEIs also attended an information meeting with the chair of the assessment panel; the meeting was organised by the SHEA. The contact with the chairpersons was expressed by representatives at the Eagle as being soothing and comforting, since the approach - that is, to assess how the HEI can make sense of the way in which their IQA covers their needs - was perceived as fair.

The work on the self-evaluations gave rise to particular challenges. Although the Falcon and the Eagle QA management both knew their weaknesses fairly well before the review, the interpretation of the SHEA's intentions demanded collective efforts. The HEIs' self-evaluations had to be organised according to a SHEA template. The basic challenge was to meet the SHEA's expectations, which were perceived as rather vaguely formulated in the guidelines. The self-evaluations were crafted in a successive and collective process of interpretation and translation. The Falcon's internal time schedule for the self-evaluation, visualised in a detailed spreadsheet, displays how the work with the self-evaluation was initiated in December 2016 and how it was followed by 27 activities, including identifying coordinators and reference groups, interpreting guidelines, holding numerous meetings, collecting data, holding discussions, undergoing multiple peer review processes, doing editorial work, doing proof reading, ensuring formal finalisation, submitting, and completing self-evaluation of the work.

Writing a self-evaluation is not only a laborious matter of describing your own strengths and weaknesses; it is a puzzle to find out what the assessor may "want" and is thereby a source for queries among those involved: "What do you think they [the SHEA] want us to write here?" (Eagle Quality Management Staff 1). As noted by Falcon management, responding to items in a template to be submitted for external review is not an easy process of representation. On the contrary, it fuels insecurity. The number of instances that the HEIs could nevertheless "misunderstand" a given explanation of a ground for judgement by the SHEA is numerous:

... the range of possible interpretations are endless (...): "well, it could be like this", "well, it could just as well be like this", "yes, but do they mean process or?". So, we were occupied up until the last day with trying to define [it]. And in the end, we just had to make up our minds and say, "no, this is what they mean". (Falcon Quality Management Staff 1)

The HEIs also discovered that they had to design images that would visually display their IQA systems. These images alone invoked collaborative achievement. As it turned out, the self-evaluations contained a number of detailed, complex, and multicoloured organisational models that served to illustrate aims, flows, visions, schemes, activities, differentiation, hierarchies, processes, and cycles. Overall, the basic ideas communicated in the self-evaluations drew on ideas from Total Quality Management (TQM) characterised by an emphasis on management responsibility for quality improvement, systematic and continuous analysis, and the improvement of work processes conducted throughout the organisation through means of involve- 
ment and empowerment. Explicit reference to the so-called Deming Cycle (i.e. the wheel of continuous improvement stemming back to the evolution of engineering and industrial production in the 1930s) displays how such modernist schemes and modes of thinking are repeatedly repacked and moulded into HEI governance regimes (cf. Stensaker 2007).

The self-evaluations also had to show that the HEIs worked with all four aspects (governance and organisation; environment, resources, and area; design, teaching/ learning, and outcomes; and follow-up, actions, and feedback) and three perspectives (working life, student influence, and gender equity; see the chapter "Relaunching National Evaluation and Quality Assurance: Expectations and Preparations"). This was to be corroborated by documents describing how this was achieved. Hence, according to the HEI informants, a lot of time was spent revising documents and uploading them on the SHEA's web-based administrative system (UKÄ Direkt) because it was "important to clarify internal processes so they could be evaluated" (Eagle Teaching Staff 1). To illustrate the scope of this work in preparing for the review, the Falcon submitted no less than 77 supplementary documents to "exemplify", "demonstrate", and "emphasise" different dimensions of their IQA (Falcon, self-evaluation document). Examples of such documents include the following:

- Internal rules

- Handbooks

- Self-evaluations

- Audits and reports

- Development plans

- Annual reports

- Expert statements

- Visions and annual reports

- Matrixes and syllabi

- Study guides

- Examinations

- Course evaluations

- Seminar instructions

- Schedules

- Benchmarking reports

- Guides

- Routines

- Information material

- Application forms

This body of documentation, and the institutional logic that their accumulation and employment constitute within the pilot, corresponds to Michael Power's (2013) conceptualisation of audit trails. These "involve the routine production of artefacts which document work routines, but which are also the micro-manifestation of larger 
performance regimes shaped by institutional demands for accountability" (Power 2013, p. 1). According to Power (2013), the mediating function of this form of documentation "means that audit trails are definable as: evidential pathways which connect traces of micro-routines to performance reporting regimes and institutional environments" (ibid.).

Thus, this early phase involved collective interpretation and translation, as well as tedious work that was strenuous and time consuming. As noted by one key actor at the Falcon, pressure to produce the self-evaluation led to extraordinary working conditions:

We were up [late], working after midnight, the last several weeks. The last time I did such a thing was when I was a doctoral student, a very long time ago. I mean, a group of people drinking coffee after midnight.... (Falcon Quality Management Staff 2)

This picture of a tight gathering of HEI actors taking a short break from work in the middle of the cold, dark Swedish winter night will be kept in mind when the reactions to the formal SHEA decision are described later in this chapter. The midnight coffee break serves as an image of the substantial personal and collective investment that a review process of this kind can entail. Despite such demanding conditions, the actors did not emphasise the heavy workload or the time and resources required as particularly problematic - rather, the tight deadline for the self-evaluation that was set by the SHEA produced frustration and discontent at both HEIs. As one of our HEI informants said, there was not enough time between the initial meeting of 1 December 2016 and the deadline for submitting the selfevaluation of 24 February 2017 to sufficiently anchor the self-evaluation or to work and reflect in decentralised groups within the organisation:

Within this short time span, we really had to compromise. We would have liked to do much more thorough, solid, and inclusive organisational processes. We did the best we could; we were out [in the organisation] and talked and collected documents and did such things (...) but it could have been done more extensively. (Falcon Vice Chancellor)

Two observations deserve to be highlighted in this context. The first is that the Falcon found the focus of the review model to be too rigid. It is based on summative ideas on evaluation rather than formative ones (Scriven 1967). As a result, there is not enough space within the boundaries of the model to qualitatively produce, develop, and use local organisational knowledge as a means for improvement. Secondly, it is noteworthy - once again - how the enterprise of quality management and IQA work appears to trigger instincts and eagerness to do more and more and to add and incorporate evaluative activities to an expanding IQA. The SHEA is not the one pushing HEIs into further expansion and immersion; it is particular categories of staff within HEI management, what Jacobsson and Nordström (2010, p. 178) would call "a community of the willing". 


\section{The SHEA}

Let us initially describe the actors at the SHEA in the context of this particular pilot. One SHEA member of staff was assigned to each institutional review and named project leader. In addition, other SHEA employees were involved in designing and preparing the new national framework in general and the institutional review in the pilot in particular. These actors were also activated during different stages of the review. The SHEA actors' backgrounds show many similar features and experiences. They had often worked at the agency for many years and held an academic degree, most commonly a Ph.D. Many of them also had previous experience from academic work and leadership. Extensive experience from EQA was also common. The SHEA project leaders were continuously and closely following "their" respective review by informing, organising, and interacting with review participants. In this way, the project leaders, to some extent, came to represent the agency in the eyes of the HEIs and the assessors.

Within the SHEA, this first phase of the pilot consisted of two basic tasks: implementing the review model and organising the actual pilot process. A handful of HEIs initially volunteered to be reviewed in the pilot. The SHEA strived for HEI variation with regards to size, scope, and geographical location. Four HEIs was considered to be enough to fulfil this. The SHEA project leaders organised external assessment panels using strategic invitations to higher education actors and based on the names nominated by the HEIs. In addition to a chairperson, the assessment panel also included a non-Swedish assessor, an actor from the HEI sector, a working life representative, and a student. According to the SHEA informants, knowledge and experience from earlier work at the agency, HEIs, or similar settings were considered to be particularly valuable for assessment panel members - similar to the experiences and knowledge the SHEA project leaders possessed. In addition, leadership skills and abilities to organise processes and instruct participants in the review were considered to be important.

Moreover, the SHEA project leaders administered the previously mentioned web-based platform where review material could be shared among parties, as well as a section on the web-based platform where the assessors in the external panels could communicate and share their work. The project leaders were also responsible for ensuring uniform and standardised processes across the different panels. This task also entailed making sure that the assessors understood the method that was to be employed in the review and that the review was consistent with principles of legal certainty. Thus, on the one hand, emphasis during the panels work was on a kind of sector-specific and contextual knowledge, such as from previous work in HEIs. On the other hand, such forms of embodied knowledge seemed to exist in parallel with ideals about objectivity based on formal principals of justice, where all cases must be treated equally (cf. Molander 2016, p. 32). We will return to this inconsistency when discussing the epistemic dimension of the pilot later in the chapter.

Extensive preparations were conducted to design templates that were meant to serve as guides in the review. In addition, the SHEA produced training and guidance 
material for assessors, which they used during a full-day training session organised for all assessors. The training of assessors foremost aimed at standardising grounds for judgements and assessments across the panels and members to make their future judgements trustworthy and legitimate. In our interviews, they repeatedly underscored the importance of dialogue (presumably a strategy to avoid the emotionally loaded policy processes preceding the existing national system described in earlier chapters in this volume). This dialogue orientation was manifested in the form of continuous meetings with assessors and with the HEI representatives and in the organised training of assessors.

\section{Assessors}

The SHEA requirements and strategic recruitment of external assessors resulted in panels with members who had the desired backgrounds. Most of them had substantial experience of evaluations in higher education, both as being evaluated in their department, discipline, educational programme, or institution and as assessors of earlier and former agency evaluations. Some of them took part in the reference groups that SHEA organised to develop the new 2016 EQA system. As a result, the assessors possessed knowledge about the system and its intentions, which they brought to the panel and the process. They also had great experience in academic work and management at different levels and were involved in QA at their department/institution. When assessors described what they need to know to take on their task, they emphasised experience with top management work at HEIs, previous experience from the SHEA evaluations, and knowledge about QA. As noted by the Falcon chairperson, their panel also benefited from the fact that the working life representative had specific and vast experience and knowledge about quality technology; it was a person "who knew the essence of the craft" (Falcon Assessment Panel Chair 1). The informants argued that the panels also benefitted from student and employer perspectives, which the representatives from these groups brought to the panels.

The chairpersons (not the full panel) took part in an initial meeting at the SHEA and with HEI actors in December 2017. The panels then received documents and guidelines from the SHEA, which they reviewed. A second meeting at the SHEA (with all panel members) aimed at presenting information to and training the assessors by outlining the preconditions of the pilot, the process, the key indicators, and the components. During these initial meetings, a set of conceptual and practical questions were raised by the assessors. As we will see later, these questions - which were advanced at the beginning of the process - were to become imperative during the whole pilot. The questions concerned, for instance, how to weigh judgements, the role of the three perspectives (working life, student influence, and gender equity), details in the SHEA guidelines, and questions that concerned central concepts, such as the meaning of the word "to assure" [att säkerställa, in Swedish]. 
Hence, the assessors had an opportunity to meet each other, with the SHEA and the HEI actors.

At this stage, the assessors did not have a clear picture of the HEIs that they were reviewing or the roles and tasks that they were expected to perform. During the first meeting, the HEIs presented their organisations and IQA systems. Since the Falcon and the Eagle were perceived as deviating from "traditional modes" of how to organise HEIs, it invoked challenges for the assessors. Initial queries about who at the HEIs were suitable for taking part in the first web-based interviews at the respective HEIs were also made. The Falcon chairperson said that this panel used the first meeting to understand the particular organisational features of the HEI that they were reviewing: "We had to translate in order to understand. 'What does this role mean?' 'Is this the same as head of department?'” (Falcon Assessment Panel Chair 1). This is another example of the particular translation problem that arises when the review implies a norm against which the object of evaluation is measured. These translations affect not only the actors under review (as exemplified in the problems described above in terms of writing a self-evaluation on the basis of a template) but the assessors who had to assimilate new knowledge about previously unknown organisational structures to conduct the review.

\section{Collecting and Providing Data}

The next stage of the pilot involved additional activities in which the assessors accessed data - uploaded by the HEIs - from the web-based platform. For the former group, deliberations and struggles about what to assess and with what criteria became increasingly pertinent. The panels used the HEIs' self-evaluations as a basis for forming an initial impression and then organised their work and prepared for the upcoming web-based interviews. Each panel member produced an individual assessment with suggestions for questions the HEI representatives would be asked, and these individual panel member texts were then edited into one document by the SHEA project leader. Each assessment panel then held a meeting to decide which questions to ask the HEI representatives in the web-based interviews, in what interview each set of questions should be raised, and to whom they should be directed. This also meant that some questions were laid aside for the upcoming site visit. The assessors who voiced certain preferences about informants for the interviews requested informants who represented different subject areas and units and worked on quality issues. At the Falcon, where management of external evaluation was more developed, a "liaison central" was organised to prepare, organise, and follow up on different activities during the pilot. Among other things, this included the web interviews and organising post-interview deliberations. 


\section{Web-Based Interviews}

The web interviews were organised as 1-day sessions with scheduled focus group interviews with approximately $20 \mathrm{HEI}$ actors in total. At the Falcon, the web-based interviews were not perceived as satisfactory. The format appears to have produced distance and certain difficulties. First, some of the students and teachers who were interviewed found it a bit daunting to have a group of top management professionals and professors asking "evasive semi-bureaucratic questions" (Falcon Student 1). The interviewees at the Falcon also felt they were being "put to the test" in a situation characterised by obvious power asymmetries and in which assessors were perceived to have certain normative preconceptions. These emotional reactions are partly linked to one of the interviews, where the Falcon actors claim that they were told to prepare for certain topics and questions, and then the assessors asked questions about other aspects. These actors felt that these questions were difficult to answer, as they did not target the actors' roles in the organisation. In this situation, the earlier mentioned "liaison central" served an important function: to comfort interviewees in what can be described as a kind of "emotional debriefing". The actors at the Eagle were, however, not as critical. Here, the assessment panel's questions were perceived as being connected to the previously submitted documents, which fostered a situation where the interviewees were constituted as being capable and well-informed.

We would like to draw attention to two issues. First, interviews taking place in a context of accountability are framed by stressors and anxieties. Regardless of whether the assessors manage to produce a safe situation, the actors representing their HEI entered the interview with the expectation of being able to answer questions that do justice to their specific organisation. Still, such systems are sophisticated, and whereas some knowledge is easily recapitulated, other knowledge often remains unformulated and is thus difficult to communicate. The preparations of the HEIs were characterised by the actors' eagerness to be honest and knowledgeable about the organisation, as well as its strengths and weaknesses. In this context, the HEIs' preparations before interviews served to inform these actors about their own work and organisation to pass this information on to the assessors. The second aspect that we would like to point out is the perceived problems in terms of fuzziness about what is assessed and how. For example, the HEI actors found it difficult to determine where the cut score was from the panel's questions. For the assessors, the self-evaluation was a central document that served as a point of departure for what to focus on and what to ask about in the web-based interviews. During these interviews, the assessment panel members took turns interviewing and taking notes, as well as deciding if the information provided was satisfactory. The Eagle assessment panel specifically found the purposes of the web interview occasion and the site visit to be a bit unclear and struggled when it came to separating issues for the web interview and the later on-site visit. 


\section{Site Visits}

Generally, our informants describe on-site meetings as far more positive and productive than web interviews. These meetings were seen as a central activity for developing mutual understandings and exchanges for all involved parties. Thus, face-to-face meetings seem to bring dimensions of embodiment into the interview that encourages discussions that move the review process forward. The HEI actors described the encounters as nice conversations and the panel as interested and well prepared. However, on-site visits also implied additional work because they were not limited to the actual meetings between assessors and HEI actors; they required planning, organisation, and preparations, and they led to forms of post-production. Overall, the exercises and the work undertaken before and after the site visit point to the fact that, even though the pilot can be divided into different phases and activities for analytical purposes, all of these activities were closely interlinked as a continuous process.

The SHEA project leaders continued to have a less visible but important role. They organised the site visit schedules, supported the panel chairperson, and kept time and discussions on track. The site visits were organised as 2 full-day sessions consisting mainly of 45-min focus group interviews with approximately 40-50 HEI actors in total, including management, teachers, students, doctoral students, and other staff and working life representatives. Each HEI actor involved in the site visit received a memorandum from the SHEA project leader outlining the visit's schedule. The memorandum also described the pilot's rationale, the assessment panel's role, and the time schedule. It declared, among other things, that each HEI actor was expected to bring a nameplate because there would be no time for presenting individuals or the organisations and units they represented. There were 15-min breaks scheduled between each session, allowing the assessors time to prepare and the HEI actors a chance to switch places.

The site visits were prepared on the basis of the self-evaluations and the SHEA guidelines, and they were specifically directed to the "audit trails" (SHEA 2016, p. 12) of areas identified by the assessors. To qualify their understanding, the assessors prepared the interviews and requested additional materials from HEIs. The QA management at the Eagle experienced a new workload peak as documents had to be uploaded to the platform all over again, this time divided differently from the uploads undertaken in connection with the self-evaluation submission. They also had to produce new documents that retrospectively described decisions already made. In all, "it was like putting together half a new self-evaluation" (Eagle Quality Management Staff 1).

In both HEIs, the site visit was prepared by specific pre-meetings for those selected for an interview with the assessors. Post-meetings were also held during site visits to transfer experiences from the initial interviewees to colleagues in line for upcoming interviews. As was the case when preparing for the web interviews, 
these measures also increased people's awareness about their own IQA to facilitate "thick descriptions" during interviews. This proved to be a successful strategy because one purpose of the site visits appeared to be controlling whether or not the HEI actors were grounded in the presentations given in the self-evaluations. In other words, site visits secured evidence that dialogue and enhancement had spread organisational knowledge within the organisation. One SHAE project leader explained:

One important matter is that they have an IQA [system] that is inscribed in some kind of policy document. Then, we come and visit them with our basis for judgements and aspects, and we look at their policy documents and their systems [IQA systems], and we do our interviews with a whole range of people from different programmes and departments, levels, management from the top to the bottom, and students and doctoral students. Then we (...) examine whether it corresponds to what they have written in their own policy documents. Here, it is especially important that they have a dialogue. Most of the people we talked to knew about the system; in this dialogue-based system where they constantly talk to each other about what they do, they have a process and discuss quality issues. They think about how they can improve. It was not perfect, and there was someone who did not know [about the IQA], but if you think about all the people we talked to during the site visit... But the assessment panel felt that "this seems to work, they appear to keep track, they know their system, they talk to each other, management is in control over departments and programmes". Enough people were aware and knew the system to motivate a Pass grade. It could have been better, but it was sufficiently many. If I try to quantify (...) if we say that we spoke to 80 people, and 65 of them kept track of the system, this is just an approximation, since you are asking about a level, just to get a theoretical number. If it had been only 20 of the 80 people we talked to, well then, it might not have been possible to give them a Pass grade. (Falcon project leader SHEA)

Here we see that quality enhancement ideas are framed within a wider logic of accountability. One of the most important facets of quality enhancement, and what the institutional review seeks to measure, is that HEIs have an IQA system that is not just put on paper but is also actually a concern of the entire organisation. The exploration of the pilot's next phase will show that formal assessments of such organisational processes are challenging.

\section{Reaching, Communicating, and Receiving Judgements}

Assessments involve complex processes of professional discretion and judgement. Instruments and frameworks in the form of rules and guidelines do not guarantee determinacy (Evans 2010). Thus, judgments in the pilot required individual and collective work and deliberation. In this process, the primary sources of judgement were, once again, the self-evaluations, their attachments and uploaded documents, and the SHEA guidelines. In addition, the site visits were also important sources of data to verify and clarify different areas. 


\section{The SHEA}

The SHEA project leaders assembled each assessors' individual judgements and texts into a single document to facilitate panels' communication. This was also done to prepare for a forthcoming meeting where review panels were invited by the SHEA to discuss assessments and judgements across the different panels. Furthermore, the SHEA project leaders supervised the panels in their judgement processes. For instance, project leaders asked assessors to specify what forms of evidence they could use to support their judgements. The project leaders emphasised that assessors' overall judgements must be unanimous and comparable between assessment panels. They were also responsible for "calibrating" the individual decisions for each HEI in the pilot. Preliminary assessments were processed by the panels, officially endorsed by the agency, and later communicated to the HEIs. The HEIs, in turn, were allowed to comment on the content for accuracy. The report then went back to the panels, and they eventually submitted their final report to the SHEA. At this final stage of the review process, several internal QA activities took place within the agency itself and involved different actors, units, and levels of the agency. Finally, the director general sanctioned the decisions to be published.

\section{Assessors}

The two assessment panels experienced different intricacy levels. The Falcon panel started sensing that they were looking at a system that already met the criteria in the beginning of the process. As the IQA was perceived as functioning well overall, the actual work of making final judgements and writing the report was viewed as unproblematic. Still, some difficulties arose in deciding the "limits for pass or fail". The Eagle panel had more difficulties. The Eagle IQA was quite new, and some parts were not operational and therefore difficult to assess. Within this panel, there were early discussions about relative weighting between criteria and about difficulties with how to interpret and assess the three perspectives. For example, insecurity emerged about what it really means that the IQA system "should be proactive, it should be systematic, it should be integrated and so on" (Eagle Assessment Panel Chair) and how this criterion ought to be operationalised. The panel members also discovered that the criteria were not internally calibrated. The criteria for gender integration, for instance, were so ambitious that they were perceived as almost impossible to pass. The assessment work went on throughout the entire review process in the form of consecutive discussions within the group. During the process, the SHEA project leader "emphasises, or she is particularly driven by, for example, the student perspective and also pushed that quite hard" (Eagle Assessment Panel member). The Eagle panel member argued that this weakened the relative independence of the assessors' work, thereby adding further entanglement. As the deadline approached, there were still diverging opinions in the external panel. At this stage, 
the SHEA project leader insisted on a unified and unanimous judgement from the panel. A consensus in the panel was considered necessary, and diverging opinions were to be transformed into a unified decision accepted by all panel members. After some deliberation, this was finally settled by formulating the overall judgement in a positive way while pointing to the areas that could not be judged as sufficient. The chair and project leader then worked with internal calibration and revision and carefully edited the final adjustments of critical formulations.

The method for summarising the judgements as outlined in the SHEA guidelines stated that all four aspects and subareas and all three perspectives must be approved for a final passing grade. If any of these failed to meet the required standards, the HEI must be included in a new review in the full-scale implementation. This method of summarising judgements eventually made it clear that the Eagle did not pass, in contrast to what some panel members had suggested. Because the guidelines did not allow for weighting between the subsections, i.e. a weakness in one subsection could not be "compensated" by strong performances in another subsection, the IQA as a whole could not be approved and given a passing grade in this case.

The main goal in the assessment process, just like in the Falcon panel, was to check for a feedback loop in the QA work at all levels, i.e. to check that quality enhancement was sufficiently established at all levels and in all parts of the organisation in a spirit of engagement and responsibility. In one SHEA decision, for example, it is argued that:

The site visit and the web interviews unambiguously show that substantial engagement and broad responsibility are taken for QA in daily work among staff and among students. However, the assessors got the impression that participation could have been even more widespread, especially when it comes to the category staff and students. (...) During the interviews, it was shown that many teachers and students did not know about the novice student survey or the improvement measures it resulted in. This is an area that the HEI needs to work on.

Once again, this is a vision of a complicated system continuously engineered to secure improvement. Each specialised role or function within it has extensive knowledge about the overall system's design, including its engineering as well as the effects of each component. Such ideas differ dramatically with the Hayekian ideals (Hayek 1945) presented in the chapter "Hayek and the Red Tape: The Politics of Evaluation and Quality Assurance Reform - From Shortcut Governing to Policy Rerouting" on how the governing of complex human systems ought to be decentralised and evolve on the basis of dispersed and tacit forms of knowledge.

\section{HEIs}

For the HEIs, the time between site visits and before the preliminary and definitive reports was perceived as long. When the preliminary judgements were communicated in the autumn of 2017, they evoked mixed emotions. The Falcon's IQA was approved and got a passing grade. The management and the board were relieved by the 
outcome, which they argued gave the organisation the positive affirmation they had hoped for when they initially signed up for the pilot. At the same time, they were a bit confused and even upset as they identified a lack of understanding of their IQA as it was interpreted by the assessors. The key actors at the Falcon had discussed whether or not to address these perceived problems in their comments to the preliminary report. These careful considerations indicate that the process was seen as risky by actors who worked within the HEIs and wanted their organisations on the safe side of a passing grade.

Among the key actors at the Eagle were various expectations for the assessment's outcome; some of the Eagle staff believed it would be a pass, and some believed it would fail. As it turned out, the Eagle did not pass, resulting in some disappointment and irritation. For example, some critical remarks were made on the assessors' sensitivity to what came across as one single critique from students. Moreover, the preliminary outline of the SHEA report was perceived as hard to understand, and it was not correct on all points. Key actors at the Eagle commented on those errors in their formal reply to the preliminary report. They had hoped for revisions in the final decision, but, instead, corrections were attached to the end of the report. In other words, the perception was that the HEIs' comments were not adhered to.

\section{Post-decision Actions and Reactions}

After the pilot decisions had been made public, the SHEA organised two meetings where the pilot was discussed and evaluated. A meeting with the HEIs that took part in the pilot took place first, and a month later, in January 2018, a larger so-called dialogue meeting took place with other HEIs that was to be reviewed in the regular upcoming cycle. The SHEA also conducted surveys with the HEIs involved in the pilot to map their experiences with the process. The SHEA worked intensely to refine the method on the basis of the pilot and the input from HEIs. In parallel with these institutional reviews, ongoing discussions were organised by the ASHEI. At four conferences between 2015 and 2017, representatives from HEIs shared their experiences by presenting and discussing their IQA systems. At an ASHEI conference in June 2017 (after the site visits), the HEIs that took part in the pilot presented their specific experiences and their suggestions to improve the new institutional review model. Key actors from the SHEA also attended these conferences, provided input, and gave updated information about their work. First, these activities display that the development of the institutional review was not limited to the pilot. Secondly, an analysis of the range of HEI and IQA presentations during the ASHEI conferences reveals a prevailing isomorphism in terms of IQA designs, as shown in the chapter "Enacting a National Reform Interval in Times of Uncertainty: Evaluation Gluttony Among the Willing”.

In January 2018, the institutional review to be implemented in the regular cycle was presented at a dialogue meeting. The grades had been changed to three levels instead of two: pass, pass with reservation, and fail. The web interviews were 
replaced by an additional site visit. There were also new guidelines with reduced details, new templates for self-evaluations, and student appendices that were published on the SHEA website. More specific requirements concerning assessors were added, such as a requirement of experience with gender equality work (SHEA 2018a, p. 25). The short time frames for the HEIs to deliver materials were questioned, but the SHEA explained that "three weeks resulted in so much materials, it was the wrong signal. It should be exclusive materials" (SHEA staff, observation notes). The new model was presented at another meeting in March of 2018, with assessors and representatives from the four HEIs and student unions included in the first regular cycle. In an interview on the SHEA website, the SHEA coordinator notes that:

There were not that many questions during the meeting, which suggests that the HEIs have followed the process of developing the method and are well-informed about the content in the new guide that describes how the review operates. From the response at the meeting, we can see that our dialogue meetings have contributed to the HEIs being well-informed and have a grip of the method and the process. (SHEA 2018b)

Thus, the pilot developed and tested the institutional review, and it worked as a governing tool that informed and legitimised the new model within HEIs. As we will show in the following, however, governing signals from the pilot were not unequivocal.

\section{HEIs}

Contrary to previous national evaluations, this pilot did not receive much attention neither media attention nor broad attention within each HEI. Moreover, the pilot seemed to largely confirm what the HEIs already knew. After receiving the decisions, the responsible staff at the Eagle worked with the identified weaknesses, most of which they were already aware of and prepared for, to improve their IQA before the upcoming reassessment in the ordinary cycle. It was seen as an efficient and safe way to improve and learn, to seek inspiration, and to align their IQA with other HEIs. Extensive work was directed to the assessed perspectives where the Eagle failed to achieve a "full score", i.e. gender equality and student influence. Actors from the Eagle also sought to make sure that course evaluation follow-ups and feedback to students were improved, and they worked to clarify internal documents and processes for colleagues. Internal documents were also revised to more clearly accommodate a student perspective and to - as it was said - make texts more "alive". Bureaucratic textual vividness was created by including reflections and knowledge about the work and the organisation in general. The Falcon continued with their well-established and now SHEA-approved IQA work. However, considering the resources, time, and work invested in preparing and carrying out the pilot's activities, issues about the actual value added from the review were raised. The HEI side was concerned that the pilot may have contributed to a growing sense of insecurity. The decisions did not include any information about what was actually missing in the 
failed IQA systems, and thus it remained unclear what actually had to be accomplished to pass.

\section{Perspectives on the Pilot: Work, Actors, and Knowledge}

We would like to highlight some observations relating to the questions raised in the beginning of the chapter on enactments, actors, knowledge forms, and governing.

\section{Expansion of QA Work}

As one of our informants told us, an effect from the 2016 EQA system and the institutional reviews may be that HEIs "start doing much more than what would really be required, just in order to be on the perceived safe side" (Falcon Quality Management Staff 1). This general expansion of practices and activities linked to QA is a discernible trend in the empirical data presented in this book. QA expansion can be seen as an important driver within a willing community (Jacobsson and Nordström 2010). This tendency to "do more QA" may be further energised by the pilot, as the informant above implied. Moreover, the comprehensive work within the SHEA and the external assessment panels to establish a systematic assessment framework proved to be very challenging and continued to elicit challenges for all parties. For example, authoritative decisions in terms of pass or fail grades triggered the HEI actors to analyse and compare decisions, but it was also accompanied by the insight that assessors' work is - and cannot be anything else than - subjective. Thus, it varies between assessment panels and across time and space.

When mapping the entire pilot process, it becomes evident that this kind of exercise implicates a huge amount of work and various forms of work that ultimately serve the purpose of governing. As noted by Clarke (2012), these efforts:

[1]ike all other forms of human labour, involve practices of transforming things. Whether the objective is to govern populations, projects, problems or processes, work (and people to do the work) is essential. Forms of work (and types of worker) are a condition of possibility: that populations might be regulated; that projects might materialize; that problems might be resolved or that processes might run smoothly. (Clarke 2012, p. 209)

The remark about work as an engine of transformation might seem obvious, particularly in relation to EQA practices, because a basic rationale underlying these exercises is orchestrating qualitative changes or improvements. Even so, we think an analysis of actual work is productive for our purposes. For instance, our attempts to make work visible have displayed examples of when evaluative practices do not "work". As noted by Clarke (2012, p. 209), "these forms of work are also the condition of other possibilities, in which the anticipated or desired outcomes do not materialise". 
We would also like to highlight the amount of work and how the expectations around this work are framed and formed. On one hand, this capacious labour is required by the SHEA and manifested in, for instance, the assessors' assignments and the HEIs' facilitation of assessors' data collection (i.e. to produce and deliver documents, to actively take part in interviews, to respond to decisions, etc.). On the other hand, there is no external limit on how much work HEIs can actually put into the process, other than the restrictions of deadlines at certain stages in the process. In our data, we observe that HEIs tended to expand their work and that certain forms of work were intensified within and between organisations. The HEIs engaged in voluntary activities of knowledge exchange and in various forms of collaborations in national networks, such as the ASHEI. The pilot evidently required a lot of time and work in the studied HEIs, at least for top- and faculty-level management and for QA staff. When we asked about the amount of resources put into the pilot, however, the HEI actors hesitated. Despite the process's careful planning and organisation in terms of activities and people, issues of time, money, and working hours were largely absent. In a sense, this "invisibilisation" of the resource aspect of QA work is to be expected as the actual work is embedded within the rationale of QA and enhancement. Such work is supposed to be integrated into all other forms of work within the organisation, and separating QA work from other work and activities is neither possible nor desirable. As noted by Power (1994), the scale and the complexity of organisations were reasons for the institutionalisation of this supposedly cheaper mode of "evaluation of evaluation". Power's concern is that indirect forms of quality control have become rituals based on compliance without substance or relevance to organisations (Power 1994). Our findings also show that EQA is not entirely functional for the HEIs. Rather, EQA is to be understood as a state mode of governing HEIs.

\section{The Work of Translations}

Work is also carried out in the numerous translations of these processes. Our data show how HEIs struggle to make IQA systems fit the self-evaluation template; assessors struggle to understand the assessment criteria and the HEIs' selfevaluations, and the SHEA staff struggle to reinforce valid and comparable judgements. Assessors and the assessed have to produce a fit between rules and cases. Even common concepts provoked uncertainty and translation processes. The assessment panels consisted of hybrid and potentially contradictory formations that collaborated under specific circumstances. They were also traversed by a particular "logic" inherent in the ESGs and the SHEA guidelines that produced indeterminacy and required them to resolve tensions, paradoxes, and contradictions. In other words, they had to translate from one form to another. The expectations were that such rules, the organisation and forms of practices within the pilot, and the personal qualities of assessors would enable politically desired equivalent and comparable review decisions (Standing Parliamentary Committee on Education 2016). From our interviews, we learn that this is a potentially impossible challenge. 


\section{The Work of Qualocrats}

Our focus on work also encourages us to consider those who perform the work. As noted by Clarke (2012), “[t]hese are not just 'hands' or 'bureaucratic functionaries' but need to be understood as having social characters, positions and dispositions that are formed in social relationships and trajectories" (Clarke 2012, p. 213). Throughout our project, we observed that persons working with EQA and its management and development are mobile and well networked. They move between HEIs, government agencies and associations, and various kinds of organisations. As we discussed earlier in this chapter, they tend to share knowledge and previous experiences. In this book, we use "qualocrats" to denote this somewhat heterogeneous group of actors who have taken on the authority and mission to, on behalf of the higher education sector, move between various domains to translate and promote certain forms of knowledge in and of QA. They carry highly valued expertise related to enacting and managing EQA, including the institutional review we studied in this chapter. Similar to Enders and Naidoo's identification of "audit-market intermediaries", we also observed "the institutional work of the new professionals who make sense of, buffer and translate institutional pressures" and how "normative frameworks and expectations [are] de-coupled, hybridised and sedimented" (Enders and Naidoo 2018, p. 10). Even if their approach is institutionally oriented, the attempt to "bring actors back in" to the institutional analysis is promising. Our project findings support such an argument, and we suggest that the qualocrats identified in our study are central actors for understanding important higher education transformations and their possible implications.

The qualocrats also contribute to the formation of what has been labelled a "quality assurance community":

A "quality assurance community" is thus both fabricated and projected (Grek et al. 2009), conceived as a homogenised collection of individual stakeholders "committed to continuous quality improvement" (ENQA 2010: 3). (Brady and Bates 2016, p. 70)

Within this community, higher education is understood in particular ways. An orientation towards goals and results is prominent, which also implies a rational, quality-oriented, and constantly improving organisation (Brady and Bates 2016). In their work, qualocrats use and promote certain forms of knowledge, which we find important to highlight. We observed a certain vocabulary and particular expertise in QA. The knowledge base is largely derived from TQM. Historically, these ideas stem from management theories such as Taylorism, scientific management, and the human relation school and are imported from the industry and from business (Newton 2000, 2010; Palmer and Saunders 1992).

Qualocrats are experts (Barrow 1999; Normand 2016), and their work can be understood as an activity of expertise:

Expertise is a specific activity of knowledge production participating in a process of negotiation and orientation of public policy. This knowledge is technical and comes from professionals working in administrations, international organisations, universities and other higher education institutions, agencies, think tanks or interest groups. (Normand 2016, p. 131) 
Technical knowledge here must be understood broadly because expertise also involves know-how, such as the capacity to successfully engage in dialogue and in guidance (Normand 2016). While qualocrats draw on scientific legitimacy - where TQM offers general ideas - their expertise is often "based on experience and social fame acquired for years" (Normand 2016, p. 131).

Such an understanding of expertise resonates with our interest in exploring various forms or phases of knowledge (Freeman and Sturdy 2014). Looking at the pilot, it is clear that certain key actors are particularly important, particularly qualocrats due to their embodied knowledge and expertise. They also possess the skills and networks to rapidly update this knowledge and to incorporate new information they learn from meetings with each other. Inscribed knowledge (e.g. in the ESG, assessment materials, decisions, etc.) is also crucial in the pilot's work. Qualocrats draw on their embodied knowledge to interpret and translate such written material to make it "actionable" (Grundmann 2017, p. 31). As noted by Normand (2016, p. 156) "the worlds of expertise [and qualocrats] are plural and they have their own logic of action which, contrary to what the technocrats think, cannot be prescribed in advance through quality frameworks and protocols".

Importantly, however, inscribed knowledge "entails particular ways of seeing, thinking and knowing and serve to constrain and discipline interactions with the world and with one another" (Freeman and Sturdy 2014, p. 11). Our data illustrates how this is played out in the various stages of the pilot process. In accordance with our focus on governing as a verb, we take a particular interest in what actors do with their knowledge. As noted by Freeman and Sturdy (2014), enactment may give rise to new knowledge beyond what was previously embodied or inscribed. In this context, meetings are crucial for such enacted knowledge. In this pilot, meetings were indeed "the basic unit of the policy process" (Freeman and Sturdy 2014, p. 12). Qualocrats and their different networking and meeting activities resemble what Haas (1992) described as an epistemic community, i.e. "a network of professionals with recognised expertise and competence in a particular domain and an authoritative claim to policy-relevant knowledge within that domain or issue-area" (Haas 1992, p. 3, cited in Freeman 2008). As Freeman (2008) points out, such epistemic communities have an important role in processing uncertainty. In the pilot, there was a continuous need for the:

[i]nterpretation of inadequate or complicated and sometimes contradictory information, and on a corollary requirement to stabilise and sustain the flow of information and interpretation to policy makers. Understandings of complex systems, in turn, have come to cast the process of communication as generative, and systems as in some sense creating both themselves and their environments. (Freeman 2008, p. 3)

Meetings, says Freeman, are essentially concerned with "the definition of the problem they are designed to address" (Freeman 2008, p. 17). In other words, meetings are sites of enactment and learning, and they are performative in the sense that objects of mutual interest are constructed through discussions. 


\section{Governing by Piloting}

This leads us to a final observation on the pilot's governing dimension, what we have labelled "governing by piloting". The pilot's very form and deliberately temporal design include work that links people, places, policies, practices, and power in particular ways (Clarke 2015) and in the form of a particular "governing project". Framing it as a pilot opened up spaces for mutual adjustments, learning, and dialogue and a priori reduced the "stakes". In these processes, there are still certain anticipatory governing signals sent to HEIs in the pilot and to HEIs not in the pilot. In this case, one governing signal was "to be on their toes". It turned out that most HEIs involved in the pilot got a failing grade, which clearly sent a message that "this system can bite, too". At the same time, there is a continued emphasis on soft norms in terms of dialogue, trust, mutuality, enhancement, and openness. This orientation and "affective atmosphere" were prominent in the process leading up to the 2016 EQA system and in the pilot. In sum, we suggest that this orientation conveys somewhat contradictory signals to actors that will be consolidated, processed, and "done" in further enactments within and beyond the regular and fullscale implementation.

\section{Finally}

This chapter analysed the pilot of the 2016 EQA institutional reviews. The chapter concentrated on the work of different actors involved in these processes and structured the "story" via three main chronological stages in the pilot, i.e. preparations, data collection, decision-making, and finally post-decision work, which included some partial adjustments of the institutional reviews. We empirically emphasised the amount of work and the forms of work done by various actors in these enactment processes. In this context, we also noted the numerous translations that continuously take place - even if the planning of the process and the level of detail in the prepared guidelines are quite thorough. One important group of actors that are enacting and brokering EQA knowledge and the work and activities that go along with it are the so-called qualocrats. We identified them as particularly central and important actors, and we will continue to highlight this group, among other things, in the upcoming concluding chapter.

\section{References}

Barrow, M. (1999). Quality-management systems and dramaturgical compliance. Quality in Higher Education, 5(1), 27-36. https://doi.org/10.1080/1353832990050103. 
Brady, N., \& Bates, A. (2016). The standards paradox: How quality assurance regimes can subvert teaching and learning in higher education. European Educational Research Journal, 15(2), 155-174. https://doi.org/10.1177/1474904115617484.

Clarke, J. (2012). The work of governing. In K. Coulter \& W. R. Schumann (Eds.), Governing cultures: Anthropological perspectives on political labor, Power, and government (pp. 209-232). New York: Palgrave Macmillan.

Clarke, J. (2015). Inspection: Governing at a distance. In S. Grek \& J. Lindgren (Eds.), Governing by inspection (pp. 11-26). London: Routledge.

Enders, J., \& Naidoo, R. (2018). Audit-market intermediaries: Doing institutional work in British research intensive universities. Studies in Higher Education. Online First. https://doi.org/10.1 080/03075079.2018.1436536

Evans, A. (2010). Professional discretion in welfare services: beyond street-level bureaucracy. Ashgate.

Freeman, R. (2008). Learning by meeting. Critical Policy Studies, 2(1), 1-24. https://doi.org/10.1 080/19460171.2008.9518529.

Freeman, R., \& Sturdy, S. (2014). Knowledge in policy: Embodied, inscribed, enacted. Ort: Policy Press.

Grundmann, R. (2017). The problem of expertise in knowledge societies. Minerva, 55(1), 25-48.

Hayek, F. (1945). The use of knowledge in society. American Economic Review, 35(4), 519-530.

Jacobsson, B., \& Nordström, A. (2010). Soft powers (in a community of the willing). In B. Jacobsson (Ed.), The European Union and the Baltic States. Changing forms of governance (pp. 163-173). London: Routledge.

Molander, A. (2016). Discretion in the welfare state. Social rights and professional judgement. London: Routledge.

Newton, J. (2000). Feeding the beast or improving quality?: Academics' perceptions of quality assurance and quality monitoring. Quality in Higher Education, 6(2), 153-163. https://doi. org/10.1080/713692740.

Newton, J. (2010). A tale of two "Qualitys": Reflections on the quality revolution in higher education. Quality in Higher Education, 16(1), 51-53. https://doi.org/10.1080/13538321003679499.

Normand, R. (2016). The changing epistemic governance of European education. The fabrication of the Homo Academicus Europeanus? Dordrecht: Springer.

Palmer, G., \& Saunders, I. (1992). Total quality management and human resource management: Comparisons and contrasts. Asia Pacific Journal of Human Resources, 30(2), 67-78. https:// doi.org/10.1177/103841119203000210.

Power, M. (1994). The audit explosion. London: Demos.

Power, M. (2013). Organizations and audit trails (Working Paper).

Scriven, M. (1967). The methodology of evaluation. In R. E. Stake (Ed.), Curriculum evaluation (American Educational Research Association (monograph series on evaluation, no. 1)). Chicago: Rand McNally.

SHEA. (2016a). National system for quality assurance of higher education. Presentation of a government assignment. Report 2016:15. Stockholm: UK ̈̈.

SHEA. (2016b). Guidelines for reviewing quality assurance procedures of higher education institutions. Pilot study. Stockholm: UKÄ.

SHEA. (2018a). Guidelines for reviewing the HEIs' quality assurance processes. Stockholm: UK ̈̈.

SHEA (2018b). Lärosätesgranskningarna drar igång $i$ "skarpt läge" [The institutional reviews start as a pilot] (in Swedish). http://www.uka.se/om-oss/aktuellt/intervjuer/2018-03-22-larosatesgranskningarna-drar-igang-i-skarpt-lage.html. Accessed 23 Mar 2018. 
Standing Parliamentary Committee on Education. (2016). Kvalitetssäkring av högre utbildning Utbildningsutskottets betänkande 2015/16: UbU9. Stockholm: Riksdagen.

Stensaker, B. (2007). Quality as fashion: Exploring the translation of a management idea into higher education. In D. F. Westerheijden, B. Stensaker, \& M. J. Rosa (Eds.), Quality assurance in higher education: Trend in regulation, translation and transformation (pp. 99-118). Dordrecht: Springer.

Open Access This chapter is licensed under the terms of the Creative Commons Attribution 4.0 International License (http://creativecommons.org/licenses/by/4.0/), which permits use, sharing, adaptation, distribution and reproduction in any medium or format, as long as you give appropriate credit to the original author(s) and the source, provide a link to the Creative Commons license and indicate if changes were made.

The images or other third party material in this chapter are included in the chapter's Creative Commons license, unless indicated otherwise in a credit line to the material. If material is not included in the chapter's Creative Commons license and your intended use is not permitted by statutory regulation or exceeds the permitted use, you will need to obtain permission directly from the copyright holder.

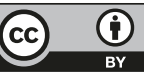




\title{
Evaluation Machinery, Qualocrats, and the Seemingly Inevitable Problem of Expansion
}

\author{
Joakim Lindgren, Linda Rönnberg, Agneta Hult, and Christina Segerholm
}

\begin{abstract}
In this chapter, we revisit our observations on Swedish higher education from the previous chapters. We initially discuss the relation between governing, evaluation, and knowledge. Then, we go back to the ideal typical notion of increasingly institutionalised evaluation machinery and locate the important work of what we label as qualocrats and what may be termed the burden of judgements within this overall frame. We finally discuss the expansion and the increasing complexity of evaluation and quality assurance work in higher education and point to some possible implications and problems.
\end{abstract}

\section{The Governing-Evaluation-Knowledge Nexus: How Evaluation Makes Knowledge Work for Governing}

In this final chapter, we highlight some of our observations on evaluation and quality assurance (EQA) in Swedish higher education. Our explorations have been guided by an interest in how governing, knowledge, and evaluation are bound together, as denoted by the term "nexus". In this work, we had a particular interest in studying how the features of evaluation as a social practice make knowledge work for governing, involving different actors, levels, and perspectives nationally and internationally. The broader context of the book is concerned with new forms of epistemic governance of higher education. Our starting point was "that the production of knowledge does not just belong to scientists: it is distributed among heterogeneous experts with a central position to give advice and to guide policymakers" (Normand 2016, p. 129). We acknowledge the role of knowledge as

\footnotetext{
J. Lindgren $(\bowtie) \cdot$ L. Rönnberg

Department of Applied Educational Science, Umeå University, Umeå, Sweden e-mail: joakim.lindgren@umu.se; linda.ronnberg@umu.se
}

\author{
A. Hult · C. Segerholm \\ Department of Education, Umeå University, Umeå, Sweden \\ e-mail: agneta.hult@umu.se; christina.segerholm@umu.se
}

C. Segerholm et al. (eds.), The Governing-Evaluation-Knowledge Nexus, 
an instrument of power and legitimisation involving language, norms, decisions, beliefs, aspirations, negotiations, and actions that emerge from various actors and institutions (Normand 2016). Throughout the book, we tried to "push theorizing to a thicker description of how actors are socially embedded and how they employ (even if implicitly) that position in influencing others" (Alasuutari and Qadir 2014, p. 71) on the basis of particular conceptions, understandings, and forms of knowledge. Our ambition here is to pinpoint the particularity of evaluation in higher education as a social practice that makes knowledge work for governing. In the book, we provided examples of how evaluation produces "constitutive effects" through forms of knowledge (Dahler-Larsen 2015, p. 24). In the words of DahlerLarsen (2015, p. 24), "the constitutive effects of evaluation extend to how we know, to our sources of knowledge" as "people change their interpretations and their actions as a result of... knowledge (officially regarded as knowledge or not) which are touched upon or enrolled by evaluation regimes". The speciality of evaluation in higher education is that it includes work on preparing, making, receiving, and acting on judgements of the quality of intangible phenomena, such as processes, responsibilities, routines, competences, relations, and support. Thereby, evaluation constitutes a certain form of epistemic governance that presupposes, uses, and produces certain forms of knowledge about a present condition that is extrapolated into a desired future. In this sense, the governing-knowledge-evaluation nexus is bound together by a utopian dimension in which evaluation is used to generate, promote, and mediate certain forms of knowledge to pledge (constant) change in ways that fit well with governing ambitions.

In the first chapters, we initially outlined the historical development of national EQA in Swedish higher education and situated this intensified political striving within an international and primarily European context. The politics of (international) comparison and the perceived political need to govern the design and the expansion of EQA, as well as its being taken for granted as a part of higher education governing, were features identified and emphasised in the initial chapters that illustrate the complexities of the governing, knowledge, and evaluation interactions. We also illustrated that the EQA policy's activities, processes, and the pace by which they are produced are important when unpacking subsequent enactments and governing work.

We documented the manifestation of these evaluative activities in terms of evolving "evaluation machines" (Dahler-Larsen 2012). In this context, we pointed to the important role of the work of particular actors, such as vice chancellors, interest groups and organisations, the media, policy professionals, intermediaries, and "qualocrats" (see below), who, via evaluation, become situated as enforcers, enablers, and governors. As our account became more empirically fine-grained towards the end of the book, these overall findings were analysed in more detail and with an explicit intention to be empirically exhaustive. In these analyses, we have shown how internal and external evaluation and quality assurance policies and practices are created, merged, and enacted (i.e. "worked"), and we pointed to the numerous activ- 
ities and the amount of labour that go into these processes. We also discussed how the forms and qualities of "knowledge" are promoted or advanced by this work and how knowledge transforms between phases through various kinds of action (Freeman and Sturdy 2015). Doing EQA thus entails various forms of translations and results in a continuous expansion of evaluative work and activities. We label this emerging process a evaluation machinery.

This final chapter is divided into two main sections. First, we continue the above discussion, initially by revisiting the ideal typical notion of an increasingly institutionalised evaluation machinery and by looking into how its engineers and main operators, the qualocrats, can be understood. We also discuss the art of making judgements, a central aspect of "binding together" forms of knowledge to make evaluation work. In the second section, we discuss the expansion in terms of the increasing complexity of EQA work in higher education and recognise some possible implications and problems in terms of resources and sustainability.

One important argument in the first section is that there are different ways in which evaluation makes knowledge work for governing. The first way corresponds with "conventional" interpretations of epistemic governance, or soft governance. Here, power and knowledge operate through certain automated technologies that trigger and stimulate behaviours. The way comparisons are introduced in the evaluation machinery offers one such example. Comparisons - and the very notion of comparability that comparisons between HEIs and/or programmes by the state and/or by students are possible - automatically initiate new behavioural protocols based on informed work within HEIs. The second way evaluation makes knowledge work for governing is located in the concrete and often meticulous daily work and interactions of actors to make evaluation work. As demonstrated in previous chapters, such work involves different forms or phases of knowledge, like inscribed knowledge. It also involves work to produce or act based on texts, such as policies, evaluation criteria, or self-evaluations. The work may also implicate meetings where language and embodied forms of knowledge are enacted to process, transmit, or produce new knowledge. This work includes numerous translations and mediations that may cause misunderstandings, inconsistencies, or problems traditionally described in terms of validity and reliability. On a somewhat different level, these laborious activities may add little to promote organisational improvement. After a demanding external evaluation, actors within HEIs may conclude that they did not learn anything about "the quality" of their work or their organisation that they did not already know. Alternatively, evaluands may find the evaluation report inaccurate, obscure, or otherwise difficult to use for purposes of organisational change. Thus, programmatic (normative) and technological (operational) elements are not always perfectly aligned (Power 1997), implying that situations occur when evaluations do not work according to official transcripts or ideals. Our point here is that, even under such conditions, evaluative activities still draw actors' attention to policies and consolidate actions related to policy in particular ways. Hence, regardless of whether evaluation actually "works", the processes initiated by 
evaluation can still make knowledge work for governing, albeit not exactly how the "evaluation machine engineers" may have intended.

\section{The Emerging Evaluation Machinery}

The previous chapters have documented the rise of Swedish EQA in higher education. Up until rather recently in the history of higher education, anything of its kind simply did not exist. In fact, just a few decades ago, any intrusion by external agencies on HEIs, their inner work, and freedom, was unthinkable. As a reminder of the pre-EQA zeitgeist, the Robbins Report on higher education, an important post-war policy document in the UK, offers a good example. In this report, it was emphasised that:

such freedom is a necessary condition of the highest efficiency and the proper progress of academic institutions, and that encroachments upon their liberty, in the supposed interests of greater efficiency, would in fact diminish their efficiency and stultify their development. (Committee on Higher Education 1963, p. 228)

Today, on the other hand, the national evaluation machinery is a permanent, institutionalised feature in HEIs, with implications for language, culture, ideas, practices, and artefacts produced by these institutions. The permanence of this machinery and the almost naturalised status of its basic and underlining principles has evolved over time in accordance with the rise of what has been described as the making of the evaluation society (Dahler-Larsen 2012), the audit society (Power 1997), the evaluative state (Neave 1998), and audit cultures (Strathern 2000). The general process by which such permanence is socially established has been the focus of much social theory. As noted by Bourdieu (1977, p. 164), “[e]very established order tends to produce (to very different degrees and with very different means) the naturalisation of its own arbitrariness". In this particular case, belief - often taken for granted - in ideas about fundamentally uncertain and fragile concepts, such as "quality" and "continuous improvement", is particularly fascinating. Travers (2007) claims that quality assurance (QA) is simultaneously pervasive and diffuse. This means, for example, that any consumer of EQA discourse will struggle to work out the actual meaning of the concept of quality. In the words of Warzecha (2017, p. 11), "the extensive explanations and notes that often accompany this term support the impression that something is defined that in fact remains completely in the dark". At the same time, quality has established itself as "the cross-boundary norm against which all areas of HEIs ought to strive against" (Schoug 2006, p. 65). One of many possible explanations of the pervasive naturalism of "qualispeak" is that it is fused with academic values, such as transparency and accountability (Lorenz 2012, p. 625, see Shore 2008). As stated by Shore (2008, p. 291):

This may also be part of the reason why audit culture is so difficult to contest; the university environment has become so steeped in managerial principles and practices that it is difficult to find that Archimedean point outside of the system that enables us to critique it. 


\section{Technologies of and in the Machinery}

In this book, we have demonstrated the role played by various technologies within the evaluation machinery. In this context, technologies are conceptualised not as material aspects, such as communication technology or other tools, but as methods and procedures for governing human beings that operate in a Foucauldian sense. We discern how technologies, such as visibility, comparability, standardisation, economic incentives, and rewards and sanctions, have become embedded in the national machinery over time. We can also discern that the techniques themselves have mutated over time.

The technology of visibility is one example of how such change is introduced for knowledge to work for governing. Visibility offers means to reduce complexity through abstraction, categorisation, and data concentration (Dahler-Larsen 2012). For instance, visibility was originally an effect of state attempts to "scan" (Gröjer 2004 , p. 64) or make all universities and their inner workings visible by means of producing comprehensive knowledge about the sector. This line of reasoning is congruent with Scott's (1998) ideas on state vision and large-scale state measures to improve society and its institutions by simplifying local practices and making them legible during the twentieth century. Simplification and legibility are associated with "a synoptic view of a selective reality" that imposes a certain "logic on the very reality that [is] observed" (Scott 1998, pp. 11-14).

Over time, visibility has transformed from a kind of "singular technology" operating through the state centric gaze upon individual institutions into a "polycentric technology" of permanent visibility. The state agency has continued its observations, but higher education institutions and actors have made themselves more and more visible not only to the state but to themselves and other institutions, prospective students, stakeholders, and the general public. As noted by Foucault (1977) in his studies on the concept of panopticon, visibility is an anonymous power that produces efficiency, responsibility, and discipline. The potential of visibility in this respect has been part of management thinking for a long time. As evidenced by the Hawthorne experiments in 1924, the observer's effect on behaviour was used to increase industrial productivity. Visibility as a technology is thus based on general knowledge, as perfected by Mayo (1946) and proponents of the Human Relations School (the forerunner to total quality management, TQM), namely, that people behave "better" when under observation compared to when left to operate on their own. Interestingly for us, visibility within the evaluation machinery has also been refined along these lines, as it has become a part of monitoring and follow-up systems that are increasingly taken for granted. For instance, recent developments illustrated in the previous chapters, in which EQA has incorporated enhancement ideas emphasising the value of anchoring, dialogue, and involvement, can indeed be discussed in relation to lessons drawn from Mayo (1946). Mayo linked governing style and morale levels to productivity levels, pointing to the need to see and listen to employees and show interest in their working conditions to increase motivation, even if conditions did not change. Such a case history complements our understanding 
of the rationale behind attempts to include all aspects and divisions of HEI organisations in continuous, expanding attempts to improve quality.

\section{The Importance of Human Interaction}

Indeed, technologies are examples of the "automated character" (Dahler-Larsen 2012, p. 180) of the evaluation machinery. Even so, we have also shown how embodiment is crucial for the construction and operation of the machinery. In this sense, our observations could be used to reconsider the line of reasoning provided by Dahler-Larsen (2012, p. 180), who emphasises how formalisation reduces "the need for expertise, wisdom, and educated staff". Our data has shown that formalisation in the context of Swedish national EQA in the form of the detailed frameworks and guidelines intended to increase homogeneity and comparability requires substantial human interpretation and translation. In this context, it is interesting to recall Wittgenstein's reminder that following rules is a social practice and that we need tacit forms of knowledge even to follow the simplest rules: "following a rule is [in fact] not like the operations of a machine" (Wittgenstein quoted in Taylor 1995, p. 168). According to Wittgenstein, rules are followed on the basis of an understanding that "is always against a background of what is taken for granted, just relied on" (Taylor 1995, p. 167). The operation of an evaluation machine demands such forms of knowledge. Then again, the scripted nature of the machine and the demands it places on representation distinguish it from aspects of more everyday social practices where rules are primarily followed on the basis of automated social understanding or "habitus" (Bourdieu 1977). Our data show that frameworks and guidelines do not contain the principles of their own applications. In our interviews, we have asked our informants how they perceive certain common concepts that are frequently used in the context of the evaluation machinery (such as "ensure" [säkerställa] or "quality"). We have recurrently observed how our informants become uncertain when asked these questions. In this sense, policy demands for homogeneity and comparability, which are based on these ambiguous concepts, seem to feed insecurity and the need for collective labour. Face-to-face meetings and negotiations between actors are often necessary for the machines to work. When actors do not trust their own interpretations, they must meet with one another to help each other "learn" to understand rules and "make sure" that they have achieved a mutual understanding of the rules. In this sense, physical meetings are crucial arenas for such interaction and work (Freeman 2008).

The importance of human interaction is a central finding of our project. As outlined above, technologies would - at least in theory - result in evaluation machines distinguished by an automated character with reduced need for human intervention and expertise. Such a version of evaluation machines would resolve problems related to coordinating dispersed knowledge following Hayekian ideals (Hayek 1945; see the chapter "Hayek and the Red Tape: The Politics of Evaluation and Quality Assurance Reform - From Shortcut Governing to Policy Rerouting”) and 
ultimately result in an anonymous, self-governing disciplinary power working in accordance with ideas presented by Foucault (1977). A possible way to understand why this has not been the case is to consider the difference between complex and complicated systems and the implications of this difference on higher education governance and evaluation. According to Glouberman and Zimmerman's (2002) distinction, complicated problems (like sending a rocket to the moon) are intrinsically different from complex problems (like raising a child or managing a health system). Whereas complicated systems are planned, predictable, and engineered, complex systems are unique, relational, and uncertain because they consist of multiple interconnected components or actors that change adaptively (Glouberman and Zimmerman 2002). This rough ideal-typical distinction is informative because it draws attention to how actors and their forms of communication are imperative for knowledge to work for governing in the realm of the evaluation machinery.

We have noted that the evaluation machinery of Swedish higher education is simultaneously a complicated system and a complex system. As a complex system, it draws on technologies that make things happen seemingly without premeditated orchestration. However, it is also a complicated system in the sense that the scale of system design and the requirements for coordination and interpretation of components by specialised experts are significant. This means that the more concrete acts of making things visible or performing comparisons are far from spontaneous or straightforward. As argued by Mowles (2014, p. 163), the above distinction between complicated and complex systems fails to acknowledge that problems of the former kind - presumably instrumental and straightforward - always comprise "widespread mutual adaptation and improvisation, disagreements, lacunae, the unexpected and the contingent". Internal and external forms of evaluation involve taking processes of management and teaching apart and analysing the details. It is a highly engineered and detailed system that requires evidence, planning, management, role definitions, and alignment. It also requires labour-intensive human interactions in the form of meetings whose purpose is to identify and eliminate fallacies caused by the differentiation and fragmentation built into the machinery. Process elements in EQA may be forgotten, described incorrectly, evaluated incorrectly, put in the wrong order, or separated or joined in the wrong places. Unnecessary process elements may be added, or mutual dependencies of process elements may be incorrectly described (Warzecha 2017). This work is inevitably done by actors, and in our project, we have identified particular forms of work in which actors - namely, the qualocrats - are situated as both engineers and operators of the evaluation machinery. Next, we turn to these actors and their background, work, and knowledge.

\section{The Work of Qualocrats}

We envision qualocrats as powerful actors in a form of government or rule (from Greek kratia and kratos) in the name of quality and quality improvement. This group of actors embraces many traditional bureaucratic values and ethics, but its power is 
concentrated not in administrative bureaus but in webs of organisations, institutions, policies, practices, and work related to QA and evaluation. Along these lines, Travers (2007, p. 11) has discussed the rapid development of QA as a new "specialist occupation" in society. Travers (2007) traces the origins of the quality movement to twentieth-century ideas about TQM in Japanese and American industry. These ideas eventually made their ways into the public sector as a form of "reinvention of government" (Travers 2007, p. 15). Qualocrats belong to this wider tradition, but no mission statement in terms of introducing management ideas from the private industry to the public sector guides them. Overall, qualocrats do not constitute a homogenous group, and they come from somewhat different occupational backgrounds. We thus want to emphasise the fluidity that marks this community of actors. A small fraction may work full-time with quality issues as quality managers in HEIs or as vice chancellors, whereas others work part-time. Directors of studies or teachers within HEIs may be "interpelled" as qualocrats and carry out qualocrat work (e.g. prepare and assemble information or answer questions) during specific evaluations. Some are asked - and agree - to work as external reviewers, and others function as quality experts that are consulted by HEIs. Notably, most qualocrats are trained researchers, and some manage to pursue their scholarly careers parallel to their work as qualocrats.

Some qualocrats in our study have a short career path within management and have specialised in issues of QA through national and international networks and organisations. Through deliberative attempts during recent decades, to encourage involvement of students in governance structures as stakeholders, such as the Bologna Process, QA issues now offer a career path for students within student unions and the European Association for Quality Assurance in Higher Education's (ENQA's) member agencies, both nationally and internationally. Other qualocrats have long backgrounds within the HEI sector and the evaluation field. This group can use their experience to bridge "old" knowledge with evolving evaluative ideas and systems in HEIs that must adhere to new societal and economic demands. Such bridging is enabled by contemporary outlooks on QA rooted in ideas that have long traditions outside the HE sector.

One way to initially locate the stature, knowledge, and work of qualocrats is to situate this group of actors within wider "professional landscape" (Brante 2013). Although their work is strongly linked to TQM and the Swedish subject Kvalitetsteknik [Quality technology, Quality management, or QA], their educational background is diverse, and there is no common doctoral programme anchoring them within the HE sector. Qualocrats are interdisciplinary, which means that "there is no robust, systematic, generally recognised, shared paradigm that unites practices" (Brante 2013, p. 6). Hence, under the surface of the seemingly coherent public manifestations of qualocrats, there may be competition and struggles over "jurisdiction and the basic doxa" (Brante 2013, p. 6). Just like semi-professionals, such as social workers and teachers, qualocrats have expanded in sync with the new layers of bureaucracy. To a great extent, they are governed by regulations and policy - but on the other hand, they have also established themselves as policy actors who influence both the making and enactment of EQA policy. As a pre-professional 
group, qualocrats have managed to create a niche for themselves in the wake of transformations within HEIs as "new modes of rationality in the public sector (such as New Public Management) has generated demands for various types of leadership experts, management consultants, specialist consultants" (Brante 2013, p. 8).

The identification of new groups of actors in the emerging field, such as EQA experts, consultants, officers, coordinators, vice chancellors, and vice deans, has been noted elsewhere. One strand of research classifies these actors as members of the growing management within HEIs who have been profoundly transformed by New Public Management and marketisation (Hall 2012; Lorenz 2012; Alvesson and Spicer 2016; Graeber 2018a, b). In pejorative terms, Graeber (2018b, not paginated) writes about so-called taskmasters who create extra work for academic staff who find themselves "spending less and less time studying, teaching, and writing about things, and more and more time measuring, assessing, discussing, and quantifying the way in which they study, teach, and write about things".

This criticism aside, most qualocrats in our study are defenders of general Humboldtian ideals in terms of academic freedom, and they see themselves as protectors of collegial norms and autonomy. Nevertheless, the qualocrats' position is far from easy, and they can be seen as relays between two narratives (Jarvis 2014, see also the chapter "Hayek and the Red Tape: The Politics of Evaluation and Quality Assurance Reform - From Shortcut Governing to Policy Rerouting"): On the one hand, they advocate traditional academic ideals and virtues, but on the other hand, they work to establish "regulatory regimes that seek to manage, steer and control the sector in ways that serve the interests of the state and the economy by applying specific ideational motifs about efficiency, value, performance, and thus the economic worth of the university to the economy" (Jarvis 2014, p. 156).

As we have indicated in the book (see the chapter "National Evaluation Systems"), the previous history of the national evaluation machinery shows that formation of qualocrats as a distinct group could have taken an alternative route. In the 1970s, early prototypes of the evaluation machines were engineered by scholars from the educational sciences who set up prospects for the future in terms of system evaluations that included information of "forms of teaching, teaching methods, students' pre-conditions, study environment, study habits, teachers' working conditions" (Gröjer 2004, p. 61). As it turned out, evaluation machines transmuted over time and made such pedagogical queries obsolete: There was no official interest in these aspects of social life in HEIs. In addition, the machine operators morphed into the current heterogeneous body of actors.

What, then, do qualocrats do? Shore and Wright (2000) identified such experts within the new political technologies in higher education almost 20 years ago and argued that they fulfil four main roles:

First, they develop a new expert knowledge and a discourse which create the classifications for a new framework or template of norms, a normative grid for the measurement and regulation of individual and organizational performance. Second, their grid and expertise are used for the design of institutional procedures for setting targets and assessing achievements. Third, certain of these experts staff and manage the new regulatory mechanisms and systems, and judge levels of compliance or deviance. Fourth, they have a therapeutic and redeeming role: they tutor individuals in the art of self-improvement and steer them towards desired norms. (Shore and Wright 2000, p. 62) 
Qualocrats, as we have come to know them in our project, correspond well with this characterisation, but there are some additional comments to be made. First, we acknowledge the dual function of qualocrats as engineers and operators of the evaluation machinery. We have noted in the book how boundaries between evaluators and those subjected to evaluation have been gradually dissolved by new modes of deliberation and influence over forms and content in national EQA. As a consequence, qualocrats - who play a central role in such processes - acquire knowledge that can be "brought home" and used in local organisations (for instance, in HEIs). Such knowledge may be manifested in strategies to organise responses to specific EQA. One example in the data, mentioned in the chapter "Re-launching National Evaluation and Quality Assurance: Governing by Piloting", was the establishment of a "liaison central" during site visits that served to coordinate actors who took part in interviews, their responses, and their emotional reactions. Such modes of qualocrat-led professionalisation of internal strategies to deal with external evaluation can determine the formal outcome of the entire exercise - it can be the difference between a pass or fail grade. In addition, the role of qualocrats is also that of mediators and translators, as their work has become increasingly regulated by inscription in frameworks and guidelines. We also see a development regarding the fourth role, steering individuals towards "desired roles" (see above). Particularly in the period after the much debated 2011-2014 national EQA system, qualocrats functioned as experts in facilitating "compensatory legitimation" and dealt with problems of distrust on the national and local level among actors in HEIs in attempts to "socialise people into certain attitudes and dispositions towards authority, performance, cooperation" (Weiler 1983, p. 273; see also Neave 1998, pp. 270 271). Finally, as we have argued above, the expertise of qualocrats and the discretion they exercise embody sets of expectations and beliefs that tend to be dissimulated as a matter of "technical" procedures or ideologically and theoretically innocent strivings for quality. In the next section, we explore this issue further by turning to the centre of evaluative work - judgement making.

\section{The Burden of Judgement}

The previous accounts of EQA in this book have recurrently touched upon the judgement making work. As we pointed out in the first chapter, judgement is an inherent feature of evaluation in which certain knowledge becomes activated and thereby used for governing. Parts of this judgement work are done by qualocrats, and some external assessors could very well be labelled qualocrats. However, all external assessors are "charged with making decisions subject to standards set by a particular authority" (Dworkin 1978, pp. 31-32 in Molander 2011, p. 321). In our study, the "authority" is the state, as represented by the Swedish Higher Education Authority (SHEA), and the "standards" are materialised in the inscribed knowledge laid down in, for example, the designs of the national EQA systems and the instructions and guidelines for the training of assessors. These standards, or 
conditional frames, constitute an inscribed "discretionary space" (Wallander and Molander 2014, p. 2) for the external assessors.

One of the conditions that frame assessors' work, their discretionary space within the machinery, was the invention of a cut-off score in the 2001-2007 EQA system (see the chapter "National Evaluation Systems"). Linked to rewards and sanctions, cut-off scores condition assessors' judgement making. The implications of cut-off scores are known from debates related to high-stakes testing, and in congruence with these discussions, we have seen how cut-off scores have been accompanied by sanctions, penalties, funding reductions, and negative publicity in the higher education sector. In addition, cut-off scores have resulted in heated discussions if they are perceived to be incomplete, flawed, or unfair because the consequences are based on judgements made by a relatively small number of assessors. Thus, judgement making involving cut-off scores tends to pull those subjected to evaluation and other audiences into this social practice in dramatic ways. Cut-off scores make it possible to judge HEIs' internal QA systems as "failed", meaning that they must take measures and be reassessed and hopefully judged in a second round as attaining the minimum standard for approval.

Another interrelated condition is the detailed manuals produced for the 2016 national EQA system, which were aimed at standardising judgements. In this work, the SHEA strove to direct external assessors' judgements in particular ways by specifying a large number of perspectives, aspects, and indicators. This SHEA work was done to narrow the discretionary space for judgements across different assessment panels. In addition, in this EQA system, all perspectives, aspects, and indicators must be assessed as good enough for the HEIs to be judged with a pass grade. The external assessors are not allowed to let a strong result for one indicator compensate for a weak assessment result on another indicator. Only if all conditions are found to be satisfactory should the assessors assign the HEI or educational programme in question a pass. Finally, the 2016 EQA design prescribes that the external assessors must reach a unified judgement. They are not allowed to attach notes saying the decision was not unanimous.

This way of defining external assessors' discretional space expresses a meansends relationship or an instrumental norm (Molander 2011; see also Wallander and Molander 2014). In the present case, this discretionary space thereby becomes reduced, in line with the SHEA's ambition to enhance comparability across panels and HEIs, a process framed as ensuring equivalent and fair judgements. In spite of these ambitions, the external assessors had to rely on "discretionary reasoning" (Wallander and Molander 2014, p. 2) to reach a final, unified judgement. They had to engage in deliberations about the circumstances and traits of an individual case to come to a decision (Molander 2011, p. 330). We find that discretionary reasoning is an appropriate expression for characterising the work of the external assessors' use of the various indicators set up by the SHEA to come to a decision on how to grade individual HEIs. Leaning on Rawls (1993), Molander (2011) discusses the premises of discretion and discretionary reasoning and points to the many difficulties that such reasoning often entails: Even if professionals "reason as carefully and 
conscientiously as possible they may arrive at different conclusions" (Molander 2011, p. 330). In this work, the external assessors' embodied knowledge is enacted in the form of previous experiences from similar work, something valued by the SHEA in their recruitment of assessors. Despite explicit formulas of inscribed knowledge in guidelines, etc., informed judgements still require discretionary reasoning, and such reasoning may end up in "sensible disagreement" (ibid.). Borrowing Rawls' expression "the burden of judgement" (Rawls 1993, Lecture 2, $\S 2)$, Molander argues that the burden of discretion implies that consensus cannot be expected in certain areas by sensible persons (Molander 2011, p. 330). Relevant facts can be complex and contradictory, and there may be disagreements about how to weight different considerations, and interpretations can vary (Rawls in Molander 2011, pp. 330-331). As noted in the chapter "Re-launching National Evaluation and Quality Assurance: Governing by Piloting”, not all external assessors were entirely comfortable with the SHEA's demands that all panels are to agree on a unified judgement and not having the possibility of, for example, a strong outcome in one area compensating for a weaker outcome in another. Long deliberations were therefore occasionally needed to reach a unified agreement that all panel members could agree on.

As mentioned above, a new condition of the 2016 national EQA system was the inclusion of detailed instructions to the assessors with a differentiation of a large number of perspectives, aspects, and indicators to be applied consistently in each assessment. Assessors had not been instructed in such detail in earlier national EQA systems. We may say that the SHEA wished to convey specific inscribed knowledge to its assessors. This knowledge became enacted as the SHEA staff organised training sessions with the assessors. The modes of inscribing knowledge in this highly complicated infrastructure of rules thus touch on the classic and recurring question through the history of science of whether a set or whole can be determined by its elements or parts. In this context, Warzecha (2017, p. 40), referring to Bertrand Russell and mathematics, has argued that "[f]or process orientation - that is the dissection of all work processes - the following holds: the more differentiated the requirements are, the more probable it is that the number of wrong interpretations, of miscalculations and misunderstandings increases". The burden of judgement is also a burden of differentiation - or as the popular saying goes: "the devil is in the details".

A different aspect of the burden of judgement is related to the dual purpose of the system to develop and control quality in higher education, as laid out in the system directions from the Swedish government (Government Petition 2015/2016:76). Evaluation and assessment theorists have long argued for the potential of assessment for development and learning, specifying formative assessments as assessments aimed at enhancing the quality of the characteristic at hand and summative assessment as the practice of making a final judgement on which to base decisions (e.g. Scriven 1967; Sadler 1989; Shepard 2000; Black and Wiliam 2009). In essence, the 2016 national EQA system is intended to combine formative assessment with a summative assessment in its control function. As noted above, the system includes a cut-off score and, therefore, a risk of being assessed as a failed HEI, which 
suggests that the outcome of the judgements involves high stakes. According to our informants, this particular feature of the system design makes the control function more prominent and the development function less so. Instead of "opening up" to assessors, HEIs have incentives to portray themselves in a more favourable light or even try to hide weaknesses.

In summary, the SHEA's work of designing the framework for assessment, as well as the work of assessors in judging the quality of the HEIs' internal quality assurance (IQA) systems, is laborious and difficult. The SHEA has invested vast energy and resources in dialogue with the HEIs to persuade them to embrace the 2016 national EQA system in a positive way. This work also includes training and dialogue with the assessors with the aim of producing equivalent and fair assessments as part of the audit process. The external assessors were selected by the SHEA on the grounds of their embodied knowledge concerning academic work and EQA, but their discretionary reasoning was constrained by extensive manuals and frameworks, limiting the discretionary space. This tells us that the burden of judgement also relates to the epistemological assumption of rationality and automatization inherent in the idea of evaluation machines (Dahler-Larsen 2012). However, some evaluation theorists, such as Eisner (1999), stress a variety of opinions in judgements to support improvement and meaningfulness: "A life driven by the pursuit of meaning is enriched when the meanings sought and secured are multiple" (Eisner 1999, p. 658). Then again, such an evaluative design is not compatible with purposes of authoritative accountability.

\section{Expansion and Increasing Complexity}

In this final section of the book, we shift focus and theoretical gears to discuss the more general issues of expansion, resources, and sustainability. Our report on the proliferation of the national evaluation machinery in higher education prompts us to ask questions about costs that are relevant today and that may become even more so in the future as, and if, the expansion continues. As Dahler-Larsen (2012) has argued:

The evolutionary imaginary inherent in the evaluation machines tends to increase the costs through steady expansion of the machines, but it also tends to keep the costs out of sight and discussion. (Dahler-Larsen 2012, p. 187)

Even if many qualocrats and HEI actors in our study are concerned about this issue, for example, the increasing workload and personnel time that is subsumed in additional EQA activities, they also take part in designing, constructing, developing, integrating, engineering, operating, and feeding the machines.

Posing questions about costs, resources, and sustainability is also a way to reduce forms of ontological reductionism and myopic vision. Evolutionary theory offers a tool to inform such choices by providing a historical perspective on social change. In this final section, we therefore turn to the American anthropologist Tainter (1988), whose work belongs to the broad tradition of Marx, Tönnies, Durkheim, and 
Parsons. We do this to discuss investments in new layers and practices of qualocratic infrastructure that have been introduced as a state response to essential problems but which may have already reached or will eventually reach a point of diminishing marginal returns.

In recent years, the literature on governance and complexity has become extensive. If we consider this book's account of the relatively short history of EQA in Swedish higher education, expansion and growing complexity stand out as decisive features. We agree with Jacobsson et al. (2015) that growing complexity involves a "dual governing problem" for the state: "its internal complexity and multifunctional nature poses a problem for the governing of the state which, in turn, significantly impacts the capacity of the state to govern society" (Jacobsson et al. 2015, p. 13). We thus identify two ways in which the concept of complexity is informative for us in understanding the governing-evaluation-knowledge nexus: first, complexity as an "object" of governance and, second, growing complexity as an "intrinsic" aspect of governance.

Often, complexity is conceptualised in line with the first interpretation, namely, as a kind of external predicament for state governance to act on, balance, and hopefully reduce. Here, complexity in the form of constant change, uncertainty, and unpredictability in the world is seen as a problem of state governance to address (Kooiman 1993; Pierre and Peters 2005; Duit and Galaz 2008; Rhodes 2011; Room 2011; Jacobsson et al. 2015). One important notion in this literature goes back to the prevalence of "wicked problems", i.e. the idea that "in the complex world of social planning" (Rittel and Webber 1973, p. 165), important socio-political problems confronting governance are inherently difficult or even unsolvable. For instance, problems within higher education, in terms of "quality" in knowledge production and teaching, may not be wicked in the same way as issues like global climate change or social injustice and poverty, but even so, they are complex, and they appear to grow even more so over time.

Our study has dealt primarily with complexity as an inherent feature of HE governance and EQA, i.e. as something that evolves as the state seeks to address and resolve various perceived problems. According to Tainter's definition, complexity in human systems is a problem-solving activity that refers to increasing differentiation and specialisation in structure combined with increasing integration and organisation of parts (Tainter 1988). Using this broad framework, our case could be summarised as an identification of how evaluative systems gradually evolve to encompass more professionals and roles; system designs that are (re)assembled and combined over time; and additional techniques, indicators, areas and aspects, templates, and information communicated through increasing numbers of channels. We have also highlighted the amount of work that goes into organising and enacting these activities undertaken within state agencies, such as the SHEA and its agency predecessors, and in HEIs.

Looking at one aspect - information sharing - we can discern a substantial change over time. Until the 1990s, information about evaluations was distributed to a small number of recipients: the evaluated HEI, the Ministry of Education, the advisory committee, the government, the parliament, and libraries. Today, the 
SHEA distributes results and other information through their website, press releases, newsletters, conferences, documents, and various social media platforms, such as Twitter, to inform a broad range of perceived stakeholders. Moreover, changes in the ways information is actually used as a problem-solving tool produce increasing complexity. Until the 1980s, evaluations primarily served the purposes of the state, and the assessed HEIs were seen as free to use information from evaluations at their own discretion (Gröjer 2004). Eventually, in the early 1990s, the idea was introduced that HEIs must actually use and adhere to what was presented in the evaluations. Follow-ups were introduced to assure compliance, and with time, economic and other sanctions were introduced along with stronger demands for comparability in the form of the idea that HEI quality ought to be comparable on the basis of information from national evaluations. As a result, these developments called for more standardised evaluations to assure that such comparability was valid, which, in turn, produced new forms of work as the evaluations themselves became the objects of examination and critique. Today, as we have shown in previous chapters, information processing has evolved, and the communication load has also become more of an internal phenomenon within HEIs. Development of IQA systems and external demands on HEIs in terms of, for instance, production of self-evaluations in new process/divisional organisations leads to more interfaces and unavoidable friction loss in communication between various actors, institutions, or parts of organisations (Warzecha 2017). Another striking example is the way in which information about IQA must now percolate within HEIs in ways that reveal certain feedback loops that constitute evidence of quality to external observers. Thus, whereas information about evaluation in HEIs was initially a matter for the state bureaucracy, it has become something that ought to be spread to and used by all divisions, units, and employees in each institution. In this way, our data indicate that EQA developments appear to contribute to more general patterns of increased information load and management in higher education.

For Tainter (1988), complexity is a neutral term - that is, neither good nor bad. It has the potential to be a productive and functional problem-solving tool but only as far as available resources allow: Complexity requires sufficient energy flows for maintenance, and more complex systems require more energy than simpler ones. Tainter's (1988) rather pessimistic conclusion from studying the collapse of civilisations and systems of agriculture and energy is that all living systems eventually reach a point of diminishing returns, i.e. a situation in which complexity grows too costly. On a smaller scale, systems of innovation and knowledge production are subject to the same evolutionary dynamics (Strumsky et al. 2010). This means that over time, growing research institutions have come to produce increasingly specialised and narrowly useful knowledge at growing costs:

The productivity of innovation is not constant. It varies not only with incentives and knowledge capital, but also with constraints. Research problems over time grow increasingly esoteric and intractable. Innovation therefore grows increasingly complex, and correspondingly more costly. It grows more costly, moreover, not merely in absolute terms, but relatively as well: In the shares of national resources that it requires. Most importantly, as innovation grows complex and costly, it reaches diminishing returns. Higher and higher expenditures produce fewer and fewer innovations per unit of investment. (Strumsky et al. 2010, p. 497) 
Interestingly for us, and as shown in the chapter "National Evaluation Systems", EQA came to be perceived as a means to address the problem of expansion and increasing complexity within higher education as elite institutions grew to mass universities in the 1960s. Such expansion involved new and growing HEIs, new research and teaching subjects/programmes, recruitment of new teaching staff, and new groups of students, which resulted in the perceived problems of efficient managing and steering. In addition, higher education has continuously been ascribed new tasks and obligations to meet the needs of a society and a working life characterised by similar dynamics in terms of increasing complexity. Over time, HEIs have continued to expand, and national EQA systems have developed correspondingly to support and audit these developments. In times of temporary economic recession, cost cutting became a dominant argument for the need for (national and external) evaluation. As "quality" increasingly became established as an umbrella term for ideal production of goods and services, evaluation remained a key solution to perceived problems.

The irony of the situation is that important higher education reforms in 1977, 1993, and 2011 related to decentralisation, freedom, and autonomy were attempts to solve problems of expansion and increasing complexity, but the complexities they intended to combat actually increased as they were enacted. EQA systems involving the audit of results or institutional reviews are based on similar ideas and are aligned to overall principles of governance through goals or objectives that have produced increased complexity rather than simplification. Thus, Tainter's (1988) notion of the evolutionary dynamics of complexity is tangential to developments in Sweden and elsewhere under the label New Public Management. Over the last few decades, decentralisation and autonomy were introduced to combat escalating bureaucratic expansion and inefficiency, but this required an increased complexity of and in measures to ensure and enforce state control of local actors (Walsh 1995; Power 1999). Thus, Geyer and Rihani's (2010) general observation on public policy is valid for Swedish higher education policy as well:

Once again, attempts at creating greater flexibility and variety in the administration and outputs of public policy were undermined by an overriding desire for central control and oversight. (Geyer and Rihani 2010, pp. 23-24)

In our studies of the recent history of national EQA, we have identified processes of oscillation, layering, and sedimentation in evaluative systems. The question is whether we can expect continuing expansion of national EQA systems in which one system is implemented only to be replaced by another some years later. To critically discuss the prospects of alternative futures, resource issues are imperative: for example, can EQA work be conceptualised as an equation involving balance between quality and return on investment? For obvious reasons, there are a number of difficulties attached to such intellectual diversion. Starting with quality, it is notoriously difficult to assess whether HEIs are actually qualitatively "better" today than 10, 20, or 50 years ago. Moreover, the role of EQA as a driver of improvement in this respect is equally intricate. Looking at the economic part of the equation and return on investment, this component is equally intangible and tends to evade empirical scrutiny. We tried to empirically document the actual cost related to EQA 
in our project. However, this turned out to be a difficult undertaking because EQA work is not limited to practices and actors whose work is displayed transparently in accounts (cf. Alkin and Ruskus 1984; Dahler-Larsen 2012; Forsell and Ivarsson Westerberg 2014). On the contrary, it increasingly disperses into networks, institutions, and people who are often not paid to do it. According to Dahler-Larsen (2012, p. 184), these activities "incur costs for which no one is held accountable". Overall, the economic dimension of EQA remains obscure, and as long as such evaluative practices appear functional and legitimate, scholars will have a more difficult time advancing critical discussions on potential problems related to diminishing returns.

A comparison with another system facing similar challenges in terms of declining return on investment may be illustrative in this respect: Within the energy system, the energy return on investment (EROI) ratio can explain how much energy is required to deliver new energy (cf. Hall et al. 2014). However, when it comes to the evaluation-governance-knowledge nexus, there is no applicable model even close to the EROI ratio. Needless to say, it would be a nearly impossible task to provide valid knowledge to inform the "values" in the above imagined equation. Even so, the "quality return on EQA investment" and the "efficiency" of continuous expansion of EQA escape examination and critical scrutiny. We know from decades of organisational studies that this kind of managerial enterprise might provide legitimacy rather than improve actual performance, but we would very much welcome such a debate, as "evaluation gluttony" (see the chapter "Enacting a National Reform Interval in Times of Uncertainty: Evaluation Gluttony Among the Willing") comes at a (yet largely unknown) price. As we have discussed in the book, such costs may extend from narrow economic values to profound human concerns in terms of how we view and choose to undertake education and science.

\section{References}

Alasuutari, P., \& Qadir, A. (2014). Epistemic governance: An approach to the politics of policymaking. European Journal of Cultural and Political Sociology, 1(1), 67-84.

Alkin, M. C., \& Ruskus, J. A. (1984). Reflections on evaluation costs: Direct and indirect (CSE Report 239). Los Angeles: University of California.

Alvesson, M., \& Spicer, A. (2016). The stupidity paradox: The power and pitfalls of functional stupidity at work. London: Profile Books Ltd.

Black, P., \& Wiliam, D. (2009). Developing the theory of formative assessment. Educational Assessment, Evaluation an Accountability, 21(1), 5-31.

Bourdieu, P. (1977). Outline of a theory of practice (R. Nice, Trans.). Cambridge: Cambridge University Press.

Brante, T. (2013). The professional landscape: The historical development of professions in Sweden. Professions and Professionalism, 3(2), 1-18.

Committee on Higher Education. (1963). Report on higher education, Cmnd 2154 (Robbins Report). London: HMSO.

Dahler-Larsen, P. (2012). The evaluation society. Stanford: Stanford University Press.

Dahler-Larsen, P. (2015). The evaluation society: Critique, contestability, and skepticism. Spazio Filosofico, 1(13), 21-37. 
Duit, A., \& Galaz, V. (2008). Governance and complexity - Emerging issues for governance theory. Governance, 21(3), 311-335.

Dworkin, R. (1978). Taking rights seriously. Cambridge, MA: Harvard University Press.

Eisner, E. (1999). The uses and limits of performance assessment. Phi Delta Kappan, 80(9), $658-660$.

Forsell, L., \& Ivarsson Westerberg, A. (2014). Administrationssamhället [The administration society]. Lund: Studentlitteratur.

Foucault, M. (1977). Discipline and punish: The birth of the prison. New York: Random House.

Freeman, R. (2008). Learning by meeting. Critical Policy Studies, 2(1), 1-24.

Freeman, R., \& Sturdy, S. (2015). Knowledge in policy: Embodied, inscribed, enacted. Bristol: Policy Press.

Geyer, R., \& Rihani, S. (2010). Complexity and public policy. A new approach to twenty-first century politics, policy and society. London: Routledge.

Glouberman, S., \& Zimmerman, B. (2002). Complicated and complex systems: What would successful reform of medicare look like? Canada: Commission on the Future of Health Care in Canada.

Government Petition 2015/2016:76. Kvalitetssäkring av högre utbildning [Quality assurance of higher education.]. Stockholm: Utbildningsdepartementet.

Graeber, D. (2018a). Bullshit jobs: A theory. New York: Simon and Schuster.

Graeber, D. (2018b). Are you in a BS job? In Academe, you're hardly alone, The Chronicle of Higher Education. Available at: https://www.chronicle.com/article/Are-You-in-a-BS-Job-In/243318

Gröjer, A. (2004). Den utvärdera(n)de staten [The evalua(ing)ed state]. Stockholm: Stockholm University, Department of Political Science.

Hall, P. (2012). Managementbyråkrati: organisationspolitisk makt i svensk offentlig förvaltning [Management bureaucracy-political power in Swedish public administration]. Malmö: Liber.

Hall, C. A. S., Lambert, J. G., \& Balogh, S. B. (2014). EROI of different fuels and the implications for society. Energy Policy, 64, 141-152.

Hayek, F. (1945). The use of knowledge in society. American Economic Review, 35(4), 519-530.

Jacobsson, B., Pierre, J., \& Sundström, G. (2015). The embedded state. In B. Jacobsson, J. Pierre, \& G. Sundström (Eds.), Governing the embedded state: The organizational dimension of governance. Oxford: Oxford University Press.

Jarvis, D. S. L. (2014). Regulating higher education: Quality assurance and neo-liberal managerialism in higher education - A critical introduction. Policy \& Society, 33, 155-166.

Kooiman, J. (1993). Modern governance. New government-society interactions. London: Sage.

Lorenz, C. (2012). If you're so smart, why are you under surveillance? Universities, neoliberalism, and new public management. Critical Inquiry, 38(3), 599-629.

Mayo, E. (1946). The human problems of an industrial civilization (2nd ed.). Boston: Harvard University.

Molander, A. (2011). Efter eget skön: om beslutsfattande i professionellt arbete [According to one owns discretion. On decision-making in professional work.]. Socialvetenskaplig tidskrift, 18(4), 320-335.

Mowles, C. (2014). Complex, but not quite complex enough: The turn to the complexity sciences in evaluation scholarship. Evaluation, 20(2), 160-175.

Neave, G. (1998). The evaluative state revisited: 20th anniversary issue of review of trends in higher education. European Journal of Education, 33(3), 265-284.

Normand, R. (2016). Epistemic governance of European education. The fabrication of the Homo Academicus Europeanus? Dordrecht: Springer.

Pierre, J., \& Peters, B. G. (2005). Governing complex societies. Trajectories and scenarios. Basingstoke: Palgrave Macmillan.

Power, M. (1997). The audit society: Rituals of verification. Oxford: Oxford University Press.

Power, M. (1999). The audit society. Oxford: Oxford University Press. https://doi.org/10.1093/acp rof:oso/9780198296034.001.0001.

Rawls, J. (1993). Political liberalism. New York: Columbia University Press.

Rhodes, M. L. (2011). Public management and complexity theory: Richer decision-making in public services. Milton Park: Routledge. 
Rittel, H. W. J., \& Webber, M. M. (1973). Dilemmas in a general theory of planning. Policy Sciences, 4(2), 155-169.

Room, G. (2011). Complexity, institutions and public policy. Agile decision-making in a turbulent world. Cheltenham: Edward Elgar.

Sadler, R. (1989). Formative assessment and the design of instructional systems. Instructional Science, 18(2), 119-144.

Schoug, F. (2006). Den kvalitetsmärkta högskolan [The Excellent University]. Utbildning \& Demokrati, 15(2), 63-80.

Scott, J. C. (1998). Seeing like a state. How certain schemes to improve the human condition have failed. New Haven: Yale University Press.

Scriven, M. (1967). The methodology of evaluation. In R. W. Tyler, R. M. Gagné, \& M. Scriven (Eds.), Perspective of curriculum evaluation (pp. 39-83). Chicago: Rand MacNally.

Shepard, L. (2000). The role of assessment in a learning society. Educational Researcher, 29(7), 4-14.

Shore, C. (2008). Audit culture and illiberal governance: Universities and the politics of accountability. Anthropological Theory, 8(3), 278-298. https://doi.org/10.1177/1463499608093815.

Shore, C., \& Wright, S. (2000). Coercive accountability: The rise of audit culture in higher education. In M. Strathern (Ed.), Audit cultures: Anthropological studies in accountability, ethics and the academy (pp. 57-89). London: Routledge.

Strathern, M. (Ed.). (2000). Audit cultures: Anthropological studies in accountability, ethics and the academy. London: Routledge.

Strumsky, D., Lobo, J., \& Tainter, J. (2010). Complexity and the productivity of innovation. Systems Research and Behavioral Science, 27(5), 496-509.

Tainter, J. A. (1988). The collapse of complex societies. Cambridge: Cambridge University Press.

Taylor, C. (1995). Philosophical arguments. Cambridge, MA: Harvard University Press.

Travers, M. (2007). The new bureaucracy. Quality assurance and its critics. Bristol: The Policy Press.

Wallander, L., \& Molander, A. (2014). Disentangling professional discretion: A conceptional and methodological approach. Professions \& Professionalism, 4(3), 1-19.

Walsh, K. (1995). Quality through markets: The new public management. In A. Wilkinson \& H. Willmott (Eds.), Making quality critical: New perspectives on organisational change. London: Routledge.

Warzecha, B. (2017). Problem with quality management process orientation, controllability and zero-defect processes as modern myths. Walsrode: Verlag für Planung und Organisation.

Weiler, H. N. (1983 Jun). Legalization, expertise, and participation: Strategies of compensatory legitimation in educational policy. Comparative Education Review, 27(2), 259-277.

Open Access This chapter is licensed under the terms of the Creative Commons Attribution 4.0 International License (http://creativecommons.org/licenses/by/4.0/), which permits use, sharing, adaptation, distribution and reproduction in any medium or format, as long as you give appropriate credit to the original author(s) and the source, provide a link to the Creative Commons license and indicate if changes were made.

The images or other third party material in this chapter are included in the chapter's Creative Commons license, unless indicated otherwise in a credit line to the material. If material is not included in the chapter's Creative Commons license and your intended use is not permitted by statutory regulation or exceeds the permitted use, you will need to obtain permission directly from the copyright holder.

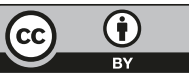




\title{
Appendix
}

\section{Christina Segerholm}

\begin{abstract}
This appendix serves the purpose of informing readers about the design, the overall theoretical approach and methodology, and the different sub-studies, methods and materials in the research project that is reported in the book: Governing by evaluation in higher education in Sweden, 2013-2018. Two particular issues concerning our research process are also included: the redirection of one sub-study due to unforeseen policy developments, and the problem of denied access. Both, we believe, may be concerns for researchers in the social sciences in general, that can open possibilities or restrict the knowledge generation process so vital for democratic societies.
\end{abstract}

This book is the result of the comprehensive research project Governing by evaluation in higher education in Sweden, 2013-2018. As we reasoned in the chapter "Governing by Evaluation: Setting the Scene", some of the findings were made possible because of the particular design of the project and its sub-studies. Therefore, a description of the general theoretical approach, methodology, design, and the different sub-studies that were the basis for the material we generated is provided. ${ }^{1}$ We also touch upon the problem of access that we encountered in our efforts to come as close as possible to the actual evaluation and quality assurance processes we were interested in studying as a way to better understand contemporary education governing in higher education.

\footnotetext{
${ }^{1}$ The appendix is a revision and update of the research proposal to the Swedish Research Council in spring 2012 (project 721-2012-5424). Unforeseen political decisions made us redirect some of our work to follow the events as they evolved.
}

\author{
C. Segerholm $(\square)$ \\ Department of Education, Umeå University, Umeå, Sweden \\ e-mail: christina.segerholm@umu.se
}

C. Segerholm et al. (eds.), The Governing-Evaluation-Knowledge Nexus, 


\section{Project Approach}

The project started out in line with the explanation-oriented (or theory-directed) evaluation approach (Franke-Wikberg and Lundgren 1980). This approach was further developed by Segerholm (2003) in order to enable critical studies of evaluations or of evaluation and quality assurance (EQA) systems. The latter approach was used to structure the project and its sub-studies. With this approach, several factors are related to each other in order to better understand and explain the consequences of EQA systems: (a) the context, intentions, and aims of EQA systems, (b) how they are carried out/the processes, and (c) their outcomes - results as expressed in reports and decisions and as experienced by representatives of the evaluators and evaluated. Issues of evaluation influence, during EQA processes and their outcomes, need to be included in such critical studies. Examples include the use of reports and decisions and enactment of decisions by different actors (Segerholm 2003). The approach also requires the development of a theoretical framework to help understand both processes and outcomes. This is typically done in an evolving process in relation to the empirical material, as was also the case in our project. In this book, such a stance is notable in our exploration of the relation between governing, evaluation, and knowledge, that is, the nexus, which is elaborated in the chapters "Governing by Evaluation: Setting the Scene" and "Evaluation Machinery, Qualocrats, and the Seemingly Inevitable Problem of Expansion". The various theoretical resources used in the different chapters in the book are also evidence of our theoretically eclectic approach. Even so, the overall conceptual frame concerning the nexus is more or less visible in the chapters.

\section{Methodology, Design, and Data}

Methodologically, Stake's case study approach (Stake 1995, 2006) was used since its logic fits well with the aims and theoretical approach of Franke-Wikberg and Lundgren (1980) and Segerholm (2003). It allowed us to view Sweden as a case, with emphasis on the latest national EQA system (the 2016 system). The case methodology also permitted us to carry out sub-studies and use several different methods for data collection and production, analysis, and reporting. A strategy of progressive focusing was helpful (Parlett and Hamilton 1972, p. 18; Stake 1995, p. 9), ensuring adaption of the line of inquiry to the shifting policy contexts, such as an unexpected period with the rare situation of a lack of a political decision on a coming national EQA system - what we call a 'reform interval' (see the chapter "Enacting a National Reform Interval in Times of Uncertainty: Evaluation Gluttony Among the Willing"). Progressive focusing implies flexibility to pursue issues that are not identified in advance. The design opted to cover $\mathrm{a}-\mathrm{c}$ in the project approach described above, in particular concerning the 2016 national EQA system. The following sub-studies were carried out to achieve this: 
Sub-study 1: Mapping the European policy context of evaluation in higher education and its intersection with the Swedish policy context

Research questions: What is the European policy on evaluation and quality assurance in higher education? How does it enter Swedish policy-making spaces? To what extent and through what channels do European ideas on EQA in higher education shape or influence Swedish practices? The study included:

(a) A review of a selection of policy literature by the European Association for Quality Assurance in Higher Education (ENQA), official texts, web-based information, brochures, and letters. Also included was an analysis of the ENQA policy of EQA in higher education in Europe and between Europe and the national context of Sweden, connecting it to literature on policy activities through which policy is disseminated, brokered, translated, and interpreted to fit national/local contexts.

(b) A study of policy channels and influences at the intersection of European and national policy brokering and mediation based on interviews with ten national 'policy brokers' responsible for the policy contacts between Sweden and Europe (particularly ENQA).

Sub-study 2: Mapping the Swedish policy context, intentions, and aims of the 2016 national EQA system, as well as key actors' notions of quality

Research questions: What are the characteristics of the 2016 EQA system's context, and to what extent does it diverge or converge with European ideas? What were the intentions and aims of the system? What different notions of quality in higher education are visible in the historical and present policy contexts? What forms of evidence do these notions of quality require? The study included:

(a) A review of the policy context and the national EQA systems in higher education in Sweden from the significant reforms of 1993-2018, exploring the main changes and the relation between European ideas on evaluation of higher education and Swedish ideas.

(b) A review of policy literature on the particular processes leading to the highly criticised 2011-2014 national EQA system, and to the present 2016 system, including the intentions, aims, and key actors, - that is, the politics of EQA. Interviews with key policy actors (so-called policy brokers) on the development of the quality evaluation system including one representative of the Association for Swedish Higher Education Institutions'(ASHEI) task force for quality issues, five officers at the two national agencies responsible for EQA in higher education during the period under study, one representative from the Ministry of Education, and one student union representative, mapping the different standpoints and notions of quality in higher education.

(c) An interview study with 33 out of 35 vice-chancellors at the higher education institutions (HEI) listed at the national agency in 2014 as central policy actors in ASHEI on their notions of quality in higher education. 
Sub-study 3: Mapping a reform interval, higher education institutions' and the national agency's preparations for a new national EQA system

As policy developments unfolded, the study turned out to be an unexpected opportunity to follow the process when a new national EQA system was in the making. Initially we applied for funds to study the 2011-2014 system, which was terminated by the time we got the research grant. At this point, we decided to redirect one sub-study to follow the process of the development of the 2016 national EQA system from an HEI perspective, in parallel with the national agency's (the Swedish Higher Education Authority, SHEA's) perspective.

Research questions: How do HEIs prepare for a new national EQA system that is not yet decided? How does the responsible national agency prepare and navigate during such a reform interval? What is the governing potential in such a reform interval?

(a) Four HEIs of various sizes, locations, histories, and previous evaluation judgements were studied through ten interviews with central quality assurance managers, faculty representatives, and teachers at the HEIs. These were a bit unevenly distributed depending on the size of the individual HEI. Documents from the HEIs, such as internal policy documents, vicechancellors' blogs, and earlier evaluation reports, were collected and analysed.

(b) Interviews with four officers at the national agency, the SHEA, covering questions about how they worked with and prepared others to work with the 2016 national EQA system.

Sub-study 4: Mapping the quality evaluation regime and evaluator practice, i.e. the pilot of so-called institutional reviews of the HEIs' internal quality assurance (IQA) systems

Research questions: What are the characteristics of the national EQA system's and the institutional reviews pilot's designs, and of the evaluators (SHEA officers and external assessment panels), and what are their notions of quality in higher education? How is the pilot negotiated with HEIs? How is the pilot carried out, what knowledge constitutes evidence, and what is the basis for judgements and decisions? How is the pilot used for policy learning?

(a) A study of the design of the present 2016 national EQA system using official texts and internal materials from the SHEA and interviews with eight SHEA staff was conducted.

(b) A study of the background, training, experience and notions of quality in higher education of staff responsible for the EQA system at the SHEA and the external experts/academic professionals (peers) was conducted. This included staff members' networks, their claims to expertise (the basis for their judgements), the selection of external assessor panels, and their modes of operation (how the evaluations are planned and carried out, what is examined, against what criteria, for how long, with what evidence). Here, we planned to collect information through interviews with assessors and obser- 
vations of their work processes, such as site visits, meetings, and introductory meetings with HEI actors in the so-called institutional review pilot. However, observations were denied (see further below), so we relied on interviews on two to three occasions throughout the institutional review pilot process with the SHEA project leaders for two of the HEIs in the pilot (the Eagle and the Falcon) and on interviews at three occasions with the chairs of the external assessor panels for the same two HEIs. Additional interviews were also conducted with one other member of the external assessor panel. A set of reference interviews with a SHEA project leader, and chair of the assessor panel, and another member of the panel for a third HEI (the Hawke) were also conducted. A staff person at the SHEA responsible for the training of the assessors supplemented this study. In order to get a holistic understanding of the institutional reviews of the Eagle and Falcon, sub-study 4 was carried out in parallel to sub-study 5 and targeted the same HEIs.

Sub-study 5: Mapping higher education practice of how to deal with the institutional review pilot of the HEIs' internal quality assurance systems

Research questions: How does the 2016 national EQA system (the pilot) enter particular HEIs? How do key HEI actors experience and react to the pilot and the 2016 system? How are they involved in evaluation events? To what extent do these processes shape their work and their views on higher education and quality in higher education?

(a) At the HEI level: We conducted case studies of reception and handling at the Eagle and the Falcon, the 'enactment' of the pilot as part of the national EQA system, its policy and practice, and its effects and consequences at the HEI level. This was accomplished through interviews with key actors responsible for quality issues at the selected HEIs and other actors taking part as representatives of different groups at the HEIs, such as vicechancellors, programme directors, teachers, and students. At the Falcon, we interviewed eight persons and at the Eagle ten persons, some of them at more than one occasion. Local policy documents concerning the delegation of power, management structures, plans and descriptions of internal quality assurance systems, and schedules for and distribution of internal quality assurance related HEI activities in relation to the pilot were collected and incorporated in the study. As in sub-study 4, we had planned to follow these processes by observations of the site visits being part of the review/evaluation process, but that was turned down due to denial of access by the SHEA (see further below).

(b) At the teaching staff level: four telephone interviews took place with randomly selected teachers at each HEI (the Eagle and the Falcon, a total of eight) in which questions about their knowledge about the ongoing pilot were asked. We inquired if and how teaching staff at the assessed HEIs had noticed or experienced that their HEI had been included in the institutional reviews pilot. 


\section{Sub-study 6: Review and synthesis}

Many of the results from our project are reported in this book. Several interviews formed the basis for more than one study since the same informants were central to a number of issues and processes we studied. In synthesising and writing the book, we strived to integrate different types of information into a chronology, wrestling with the governing-evaluation-knowledge nexus, and doing justice to what we learned throughout the project. There are still avenues and materials that are not fully explored, but we believe that this project with its comprehensive scope concerning one case - the Swedish - and its special design, shed light on and may be used as a comparative basis for studies of other national/state/ regional EQA systems and their part in governing higher education.

$\begin{array}{ll}\text { Summary of interviews } & \\ \text { Vice-chancellors } & 33 \\ \text { Policy brokers } & 10 \\ \text { SHEA staff } & 5+5 \text { SHEA project leaders for Falcon, Eagle and } \\ & \text { Hawke institutional reviews pilot } \\ \text { HEIs: } & 1 \\ \quad \text { Hercules } & 4 \\ \text { Orion } & 2 \\ \text { Pegasus } & 3 \\ \text { Virgo } & 14 \\ \text { Falcon } & 14 \\ \text { Eagle } & 10 \text { including assessors from Falcon, Eagle and Hawke } \\ \text { External assessors } & \text { institutional reviews pilot }\end{array}$

${ }^{a}$ Note that the number of interviews listed here and the number of interviewees reported in the substudies are not the same. The reason for this is that some of the interviews were used in more than one sub-study (e.g. the SHEA project leaders and vice-chancellors) and some interviewees were interviewed more than once

Most of our documentary material and interviews are in Swedish, meaning that all citations from texts and quotations from interviews are translated into English by us. We have noted in several chapters the importance of translation and are of course aware of the difficulties in capturing and transmitting meaning in these interpretation and translation processes.

\section{The Problem of Access}

As indicated in the above description, we had planned to observe assessment and judgement practise on the one hand and enactment processes at the HEIs on the other hand, in the same reviews/evaluation processes. In our contact with the 
evaluation department at the SHEA, we requested access to observe the site visits that the external assessment panels and the SHEA project leaders carried out at the HEIs in the institutional review pilot. In our request, we underscored that we would not select review processes in which the HEIs we worked in ourselves were assessed. We also asked for access to the electronic systems for the external panels' internal communications as well as the HEI's uploaded material (self-evaluation reports, etc.). Both our requests for access to review process and materials were however denied. The reason was:

When exercise of public authority is at hand, serious demands are made on administration
in line with central requirements for the rule of law. It is important that the higher education
institutions trust that the reviews are not influenced by irrelevant concerns. To allow
researchers employed at some of the higher education institutions reviewed by the SHEA to
follow the review process may risk that the administration of the review is questioned. Yet
another circumstance to take into account is that the working material that is developed
during the review process would be public documents when you get access to it, since these
documents would be considered public when they come in to other authorities, Mid Sweden
University and Umeå University. ${ }^{2}$ This would jeopardise or risk inhibiting the SHEA's
review work. (SHEA staff, email 18 March 2016)

In the same communication, we were offered the opportunity to interview the SHEA staff we found necessary to get information from. We have indeed experienced good access to SHEA staff, and they have been willing to be interviewed and share their experiences and perspectives. This has of curse been very valuable to us. Still, we discussed this reply from the SHEA and contacted a university lawyer in order to find out the legal grounds for the SHEA position and answer. The information from the lawyer was that the SHEA could not prevent us from participating in the HEI site visits if the HEIs allowed us to be there. However, we decided not to proceed, as explicit consent from SHEA was not obtained. In December 2017, when the whole process of the institutional review pilot was finished and the decisions had been formally issued by the SHEA, we again approached the agency and asked for permission to access the electronic platform used by the external assessment panels, this time in retrospect after the formal decision, but were again denied access.

From our previous experiences with empirical research on school inspection carried out from 2010 to 2013, we knew that observations of on-site process activities add important information. In this light, and having been permitted to access such activities in previous projects, we regret that we were not allowed to observe actions, interactions, gestures, mimics, and verbal communication this time. We wanted to accompany assessors to their HEI site visits and observe internal SHEA meetings and the deliberations in external assessors' meetings. This would have added additional and valuable dimensions to our data and analysis. As Travers put it, we wanted:

\footnotetext{
${ }^{2}$ Public HEIs are national authorities in Sweden and as such subject to the principle of public access. The principle decrees that all documents in paper or electronic format that are kept at, incoming to, or developed by an authority should be open to any individual for reading. Exemptions are documents that are classified or restricted or directed as personal communication to a public officer. Public access is laid down in the Freedom of the Press Act, SFS (1949:105, Chap. 2), and in the Public Access to Information and Secrecy Act, SFS (2009:400).
} 
to observe what actually happens when inspectors deliberate about the performance of an institution, or professionals review issues about quality, or managers discuss concerns about the performance of professionals. It is by spending time in what the American sociologist Erving Goffman (1959) called these 'backstage' settings that one can gain most insight into what people understand by the term 'quality'. (Travers 2007, p. 2)

We also think that it is important in a democratic society to be able to study the practices in national authorities to gain insight into how policy and governing come about in education (and other policy areas). We still hope this will be possible in the future.

\section{References}

Franke-Wikberg, S., \& Lundgren, U. P. (1980). Att värdera utbildning. Del 1 [To evaluate education. Part 1]. Stockholm: Wahlström \& Widstrand.

Goffman, E. (1959). The presentation of self in everyday life. Garden City: Doubleday.

Parlett, M., \& Hamilton, D. (1972). Evaluation as illumination: a new approach to the study of innovatory programs (Occasional paper). Edinburgh: Edinburgh University, Centre for Research in the Educational Sciences.

Segerholm, C. (2003). Researching evaluation in national (state) politics and administration: A critical approach. American Journal of Evaluation, 24(3), 353-372.

SFS 1949:105. Tryckfrihetsförordningen [Freedom of the Press Act].

SFS 2009:400. Offentlighets- och sekretesslagen [Public Access to Information and Secrecy Act]. Stake, R. E. (1995). The art of case study research. Thousand Oaks: SAGE Publications.

Stake, R. E. (2006). Multiple case study analysis. New York: The Guilford Press.

Travers, M. (2007). The new bureaucracy. Quality assurance and its critics. Bristol: The Policy Press.

Open Access This chapter is licensed under the terms of the Creative Commons Attribution 4.0 International License (http://creativecommons.org/licenses/by/4.0/), which permits use, sharing, adaptation, distribution and reproduction in any medium or format, as long as you give appropriate credit to the original author(s) and the source, provide a link to the Creative Commons license and indicate if changes were made.

The images or other third party material in this chapter are included in the chapter's Creative Commons license, unless indicated otherwise in a credit line to the material. If material is not included in the chapter's Creative Commons license and your intended use is not permitted by statutory regulation or exceeds the permitted use, you will need to obtain permission directly from the copyright holder.

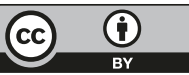

